Historic, Archive Document

Do not assume content reflects current scientific knowledge, policies, or practices. 



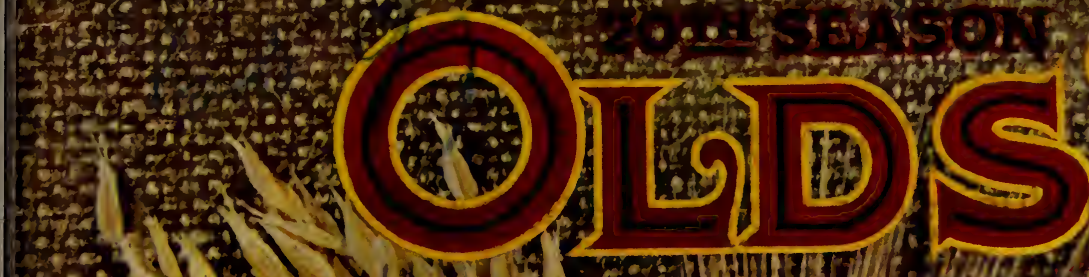

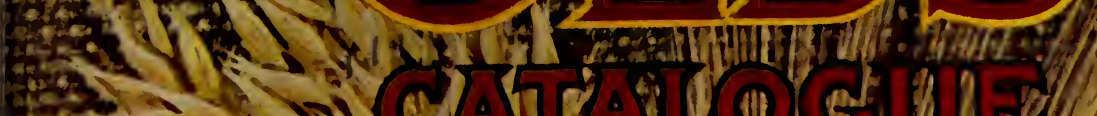

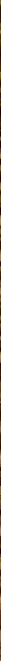

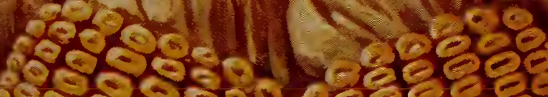

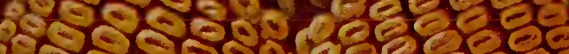

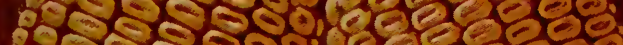

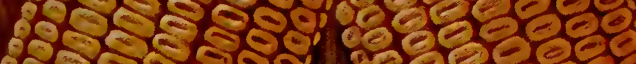

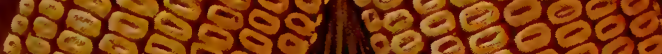

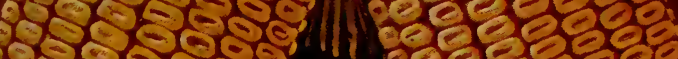

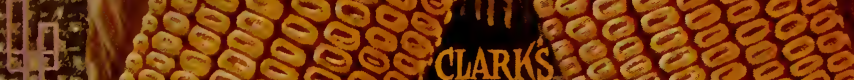

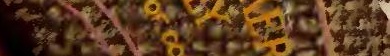

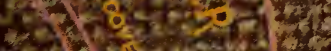

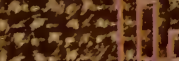
$36-2-1$ IMPROVIT

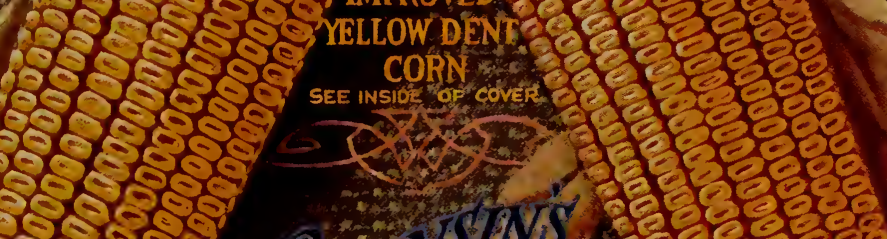

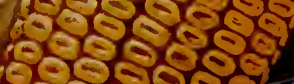

$\cos 20-5$

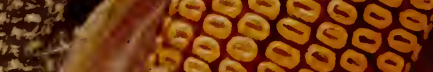

insesen-

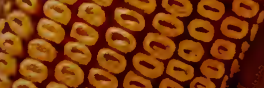

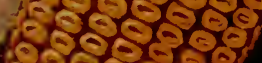

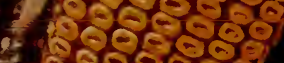

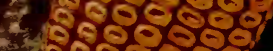

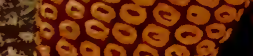

1000005

700000

listif

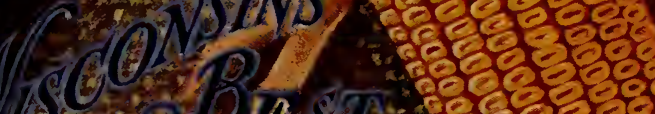

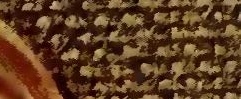

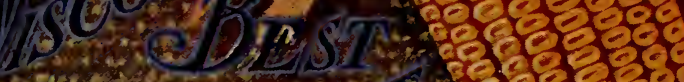
4. (5) र. 1 . - 5 - 500 -

$2+2,1$ 1
8
50
50
50
50

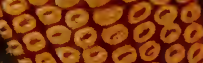


This catalogue is intended to appeal to those seed buyers who want first-class stock at the lowrest and who expect to have their orders filled who can appreciate honest descriptions and illustrations The first eighteen pates of orders filled with seeds just as represented.

varieties. Then follows our general list of better know to what we consider the best of the newer as they have always been a specialty with us. Next in or standard varieties. Potatoes come first field seeds, followed by garden seeds, vegetable and flow order is corn, then oats, barley and other pages of garden tools, poultry supplies, ete. See complete index bulbs and plants, and finally a few Look the catalogue over carefully. It is plain complete index on the last page.

It does not blow as much as some, but who wants wind? kindly hand the extra one to a neighbor. Tell him you have found us reliable, if it is the truth.
We will appreciate it.

\section{OUR PURPOSE}

To have the best of everything; to send out a neat, attractive catalogue with truthful illustrations and descriptions; to be prompt; to be courteous; to be satisfied with small profits; to be honorable in our dealings, and to treat every customer so that he will want to order a gain cusshort, to treat him as we would like to be treated.

\section{OUR RESPONSIBILITY.}

a firm they know nothing pleased to know nothing, about. We should be bility to liave you inquire as to our responsi. Brailstreet's or stamp or return postal) of Citizens Bank of Clinton, of anercial Ageney, of in Clinton or of any of of any business firm

1. QUALITY, OUR THREEFOLD GUARANTEE.

suitable for seed. If they prove atherpotatoes and seeds we send out to be as represented, and we have satisfactory proof within a reasonable will refill the order or return the monez provided urther than the amount of the order.

crop tance is made by P. O. or Express Order, the Money Order. Deduct the same from the or Registered Letter. We will also pay the cost of Small amounts may be sent safely in postage stamps. of your order. Do not send local checks.

3. SAFE ARRIVAL. We guarantee everythin we

freeze on the road we will refill the order if the time send out to arrive in good order. If potatoes arrive in bad order, however, they must if the time of shipping was left to our discretion. If they fied to by him in writing. We usually be examined by the Station Agent and their condition certirailroads give us refrigerator service now for allping potatoes to points south in February. The

\section{TERMS AND INSTRUGTIONS FOR ORDERING.}

OUR TERMS are: Cash with the order. We acknowledge freight and express orders the day received, and the same are filled and shipped as promptly as possible. Bill of Lading for every freight shipment is mailed when shipment is made. Small orders to go by mail are sent out a every freight e sure to retain a copy. You use order sheet found in catalogue in making out your order, and

WE SHIP BY FREIGHT unless forget and think you have ordered things when you have not. safe. See table of freight rates on page 88. Clinton, or Clinton cheaper than express and perfectly s 78 miles from Chicago on the C. \& N W. Clinton, or Clinton Junction, which is the same place, CUSTOMERS PAY FREIGHT OR EXPRESS on from Milwaukee on the C. M. \& St. P.

have both the American and United SARESS on all goods unless they are offered postpaid. We rywhere now on all seeds. In the main the rate is 20 per cent less the special express rates NO CHARGE FOR PACKING OR PACKAGES. Everything will bess than the merchandise rate. delivered free at the Freight, Express or Post Office, without extra charge for packed and labeled and

PREPAID STATIONS. If there is Post Office, without extra charge for barrels, boxes, sacks, ete. paid, and in such case we must request you to at your railroad station the freight has to be preamount. We must also make the ruest you to send sufficient money with your order to corer the freight or express charges nearly or quite equal the valomers living at such great distances that ORDER EARLY. Do this for two reasons. We value of the goods.

tention if received before we get into the rush of the spring shipping and careful and prompt at is complete early in the season and your order will not have to be held, and second, our assortment mission to substitute for varieties your order will not have to be held while we write you for per-

\section{WISCONSIN'S BEST THREE, (SEE FRONT COVER.)}

\section{OLDS' THE BEST THING IN}

(Oderbrucker or Wisconsin No. 55.)

For complete description, see pages 4 and 5.)

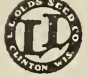
strictly new high-grade barley. Never rowed, like the Mandscheuri, and sixto that famous variety in appearance manner of growth, but of new blood and a heavier yielder. Prof. R. A. Moore, Agronomist at the Agl. College, Univ. of Wisconsin, says: "The most satisfactory barley from all points of view grown on the Station farm.'

Members of the Wis. Experiment Association who tested the new barley the past season are the yield of Mandscheuri and other varieties. Many speak of its having a stiffer straw than other varieties, and several report it heavier and plumper. Others speak of the unusually long heads. See just what they all say on page 5 . Make up your mind to sow this new variety in 1907. It is the coming barley. Don't say the price is too high. Our prices are very reason able for so valuable a variety. It will pay you to sow all your barley ground to it. Send your order to us and you will be sure of getting pure, seed.

Prices of Oderbrucker Barley-By mail: 2-oz. pkg., 10c; lb., 30c. By freight: Lb., 20c; $1 / 2 \mathrm{pk}$., $30 \mathrm{c}$; pk., $50 \mathrm{c}$; bu., $\$ 1.50 ; 2$ to 10 bus. at $\$ 1.35$; 10 bus. or over at $\$ 1.25$. Bags free.

\section{SWEDISH SEEST IN CORN.}

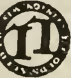

\section{(See also pages 6 and 7 .)}

Swedish Select is not strietly a riety, but it is so very valuable that we again give it a most prominent place. In line that compares with it. It is heavy, it is pure white, it is thick-meated, it stands up well and it outyields all others. U. S. Dept. of Agr. says: "Now probably the best American oat." Wis. Station says: "Most satisfactory of all varieties tested", and "Most popular variety now grown." South Dakota says: "Best we can find.", Prices: $1 / 2$ pk., $20 \mathrm{c}$; pk., $30 \mathrm{c}$; bu., $90 \mathrm{c} ; 21 / 2$

to 10 bus. at $75 \mathrm{c} ; 10$ to 50 bus. at $70 \mathrm{c}$.

\section{CLARK'S IMPROVED YELLOW DENT}

\section{(Wisconsin No. 1.)}

(See page 2 for complete description.)

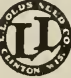
We introduced this corn to our customers last year as being "the nearest approach to a pure-bred corn of anything thus far produced in Wisconsin, , were Prof. Moore's words. He recommends it as the best yellow corn for Southern Wisconsin. Our stock is an improved strain of the original Clark's Yellow Dent. The ears are good sized, uniform in color and shape, well filled out the entire length, and it outyields everything else Prices-On the Ear: Bu., $\$ 3.00 ; 5$ bus. at $\$ 2.85 ; 10$ bus, at $\$ 2.75$. Shelled: $1 / 2$ pk., $50 \mathrm{c}$; pk., 85 c; bu., $\$ 2.75 ; 21 / 2$ bus. or over at $\$ 2.50$. 


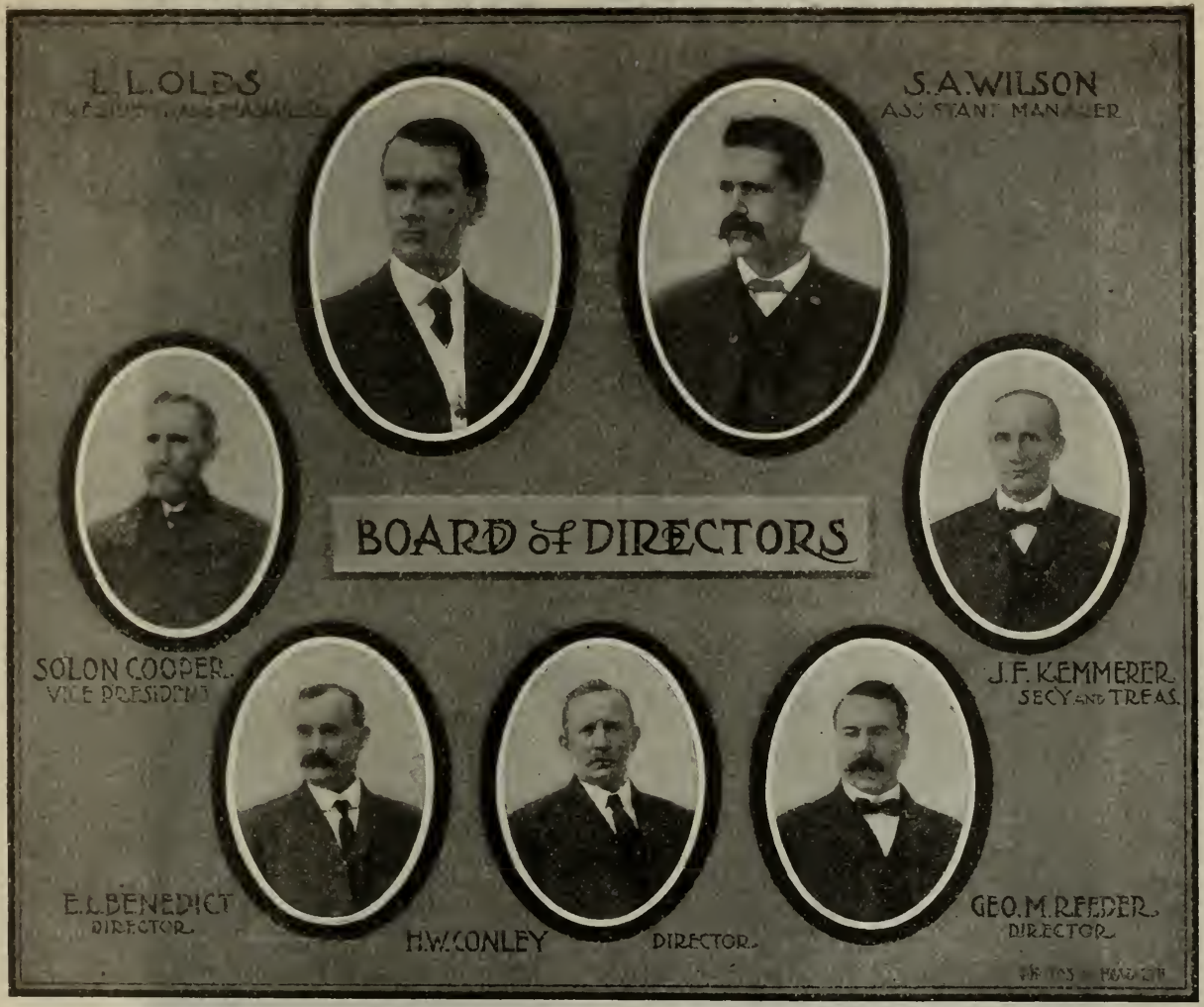

TO CUR FRIENDS AND CUSTOMERS:

Clinton, Wis., Jan. 1, 1907.

We thought our old customers, and perhaps some of the new ones, would be interested in seeing what sort of looking men they are dealing with. Hence the above picture.

We are farmers as well as seedsmen. Mr. Olds always lived on a farm until six years ago, working the farm and carrying on his seed business at the same time; MIr. Wilson, who has special charge of our Garden Seed Department, is an expert gardener and seedsnian of over 20 years' experience; and of the remaining fire directors, two are now living on farms and are actirely engaged in farming and market gardening; while the other three, although now prominent business men of Clinton, began as farmers and were all brought up on the farm. It will thus be seen that we are all of us pretty close to the farmer and well understand his needs.

Then we are located in the country, surrounded on all sides by the best farming land. We are right where things grow and where we can inspect our crops of growing seeds. The city seedsman sees very little of growing crops, and everything he sells must be shipped to him, thus increasing the cost. We submit the proposition that we are in better position to furnish seeds to farmers and give them what they want at right prices than the city seedsmen.

Our entire business increased 28 per cent last year over the preceding year. We are rery grateful to our customers for this, but for 1907 we want to make a still greater increase. Our stock of potatoes and seeds at this writing is by far the largest and finest we ever had. In fact, our great problem has been to find storage room for our immense stock. Our two large warelouses are full to overflowing, we have rented and are occupying another large building, have a lot of potatoes stored in farmers' cellars near by, and several car-loads of grain and seeds still to come in.

We are specialists in choice Seed Potatoes. The president and manager of our company has made a careful study from boyhood up of the best varieties and best methods of growing and handling and is looked upon as somewhat of an authority on potatoes. During his 19 years' experience as a seedsman he has introduced a number of new varieties that have become famous. Our potato yield the past season here at home was not quite as large as usual, but the seed is all the better for that because not overgrown. Our Red River crop was unusually large and fine. Altogether we have in store at this writing over 20,000 bushels of seed potatoes, all keeping nicely.

Seed Corn is another item we have been giving much attention to during recent vears. We are trying to furnish the farmers a high-grade article, such as we would want to plant ourselves. We have some splendid new varieties that we offer this year. We look for an unusual demand for seed.

We handle immense quantities of Field Seeds of all kinds. These are grown here and at other points, being shipped in in car lots. We supply other seedsmen, and are in position to take care of car-load and otler large orders to the very best advantage, as well as the small orders.

Our Garden Seed trade increased nearly 80 per cent last year, a splendid showing. There is a reason. No better seeds can be secured, and our prices, considering our discounts, are probably lower than those of any other reliable firn. Prices do not make quality. We are content with small profits.

Why not give us your entire order this year? We have the goods and the facilities for handling orders promptly, and we believe our prices are right. If you think we are out of line on some things, write and tell us so, and if you need large quantities of anything, ask for special prices.

Hoping to hear from you all with some good orders, we remain,

Yours very truly, 


\section{NEW VARIETIES FIELD SEEDS}

\section{THREE NEW VARIETIES OF WISCONSIN CORN.}

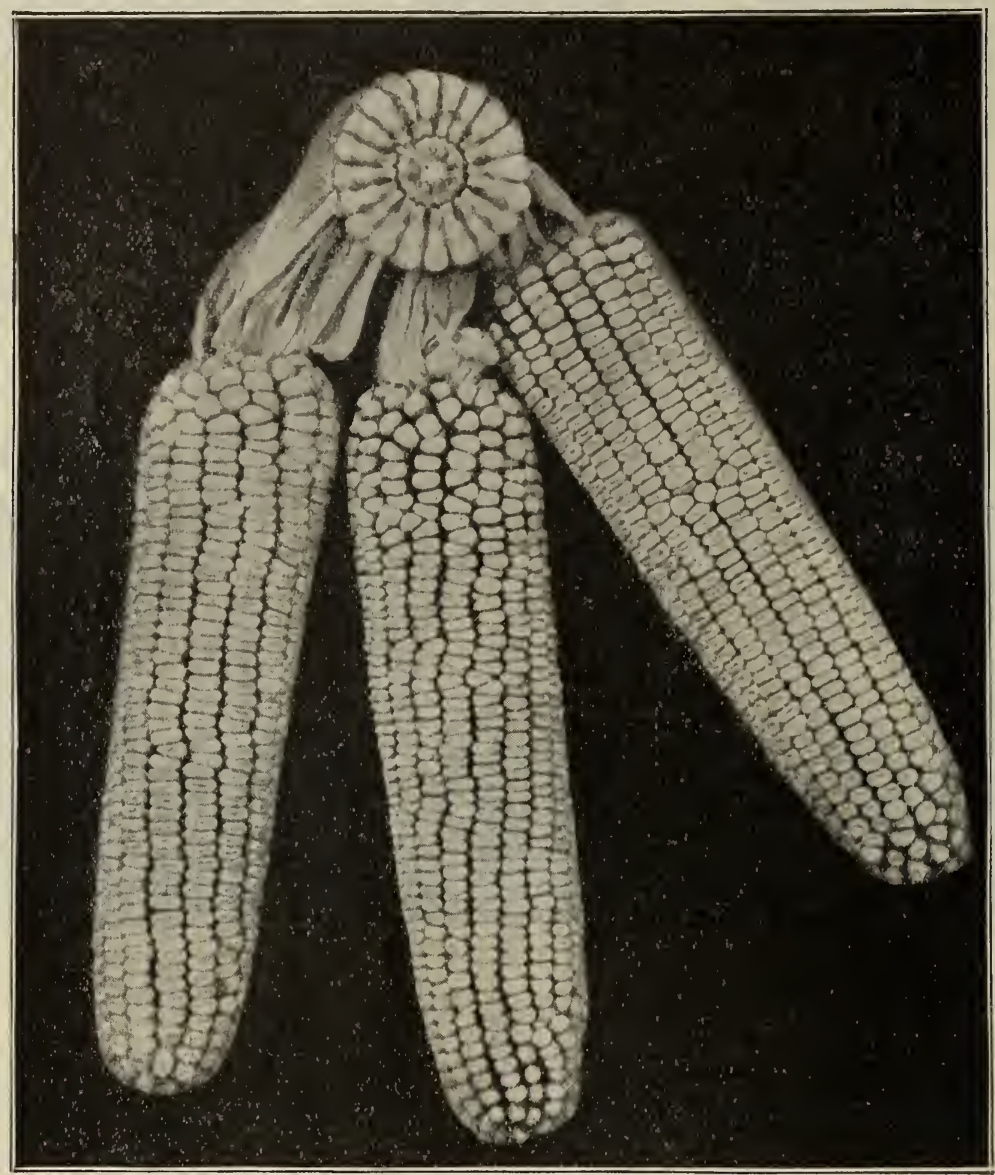

Clark's Improved Yellow Dent, with Cross-Section.

CLARK'S IMPROVED YELLOW DENT (Wis. No. 1).

A Deep-Kerneled, Large-Eared Early (See Front Cover.).

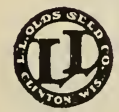

Last year we gave the prominent place in our catalogue to Murdock Yellow Dent as the largest extra early and the best all-round corn for nearly the whole of Wisconsin and states of the same latitude. Clark's Yellow Dent is a little larger than Murdock, has a decidedly deeper kernel, is just about as early and will yield considerably more per acre. It originated right here in Wisconsin only a few miles from us with Mr. Ben Clark, an old corn grower of Walworth county. The corn always breeds very true to type, uniform in color, size and shape of ear, always splendidly filled out at tip and butt; kernels of a bright golden color, compactly set on the cob, and of unusual length for so early a corn. A very noticeable thing is that the ear's hold their size almost to the tip instearl of tapering out to a long, slim point, or showing a bare cob. Stalk is strong and rather large, with one good ear to every stalk.

Our strain of Clark's Yellow Dent is an improved strain, specially developed by Prof. R. A. Moore, of the Wis. Agricultural College, for larger ear and deeper kernel than the original. Most of our stock was grown here at Clinton. Some comes from the central part of Wisconsin. Farmers of central and southern Wisconsin and similar latitudes, you can plant this corn with confidence. It will get ripe, and will give a big yield.

Prices-on the Ear: Bu. (70 lbs.), $\$ 3.00 ; 5$ bus. at $\$ 2.85 ; 10$ bus. at $\$ 2.75$. Crates free. Shelled (saved originally for ear corn): $\frac{1}{2}$ pk., 50c; pk., $85 \mathrm{c}$; bu. (56 lbs.), $\$ 2.75$; $2 \frac{1}{2}$ bus. or over at $\$ 2.50$. Bags free.

(See what we say about our ear corn and shelled corn, and about our guarantee on page 30. See also page 30 for prices of single ears and quarts. Small packets free to intending purchasers. See page 8.) 
SILVER KING (Wis. No. 7).

"Superior to any other White Corn in the State."-Prof. Moore.

Here is the corn that just suits Prof. Moore, of the Wis. Ex. Station.

Originally from northern Iowa, it has been selected and developed with a view to producing a pure white corn with deep kerne and of uniform type enough for safe planting in Wisconsin.

The corn is a beauty. Just the right length, averaging 8 to 9 inches, always filled out clear to the tips, and pure snowwhite in color. Not quite as large as Clark's Yellow Dent, but a little earlier. For yield it beats everything. 275 members of the Wis. Ex. Association from $\mathbf{7 1}$ counties the past season reported an average yield of 59.2 bushels of shelled corn per acre against an average of 49.2 of all other varieties reported. A pretty good showing when it is remembered that the average yield for all corn in Wisconsin was only 33 bushels.

Prof. Moore wrote us under date of Oct. 3: "I have just had a bumper crop. Would not be surprised to see it go 75 or 80 bushels of shelled corn to the acre. We never had such corn before, and all the people who are growing the Wis. No. 7 think it is

the greatest corn they Photograph of Three Typical Ears Silver King, Grown at Wis. Ex. Station.

have ever attempted to Photograph of Three Typical Ears Silver King, Grown at Wis. Ex. Station.

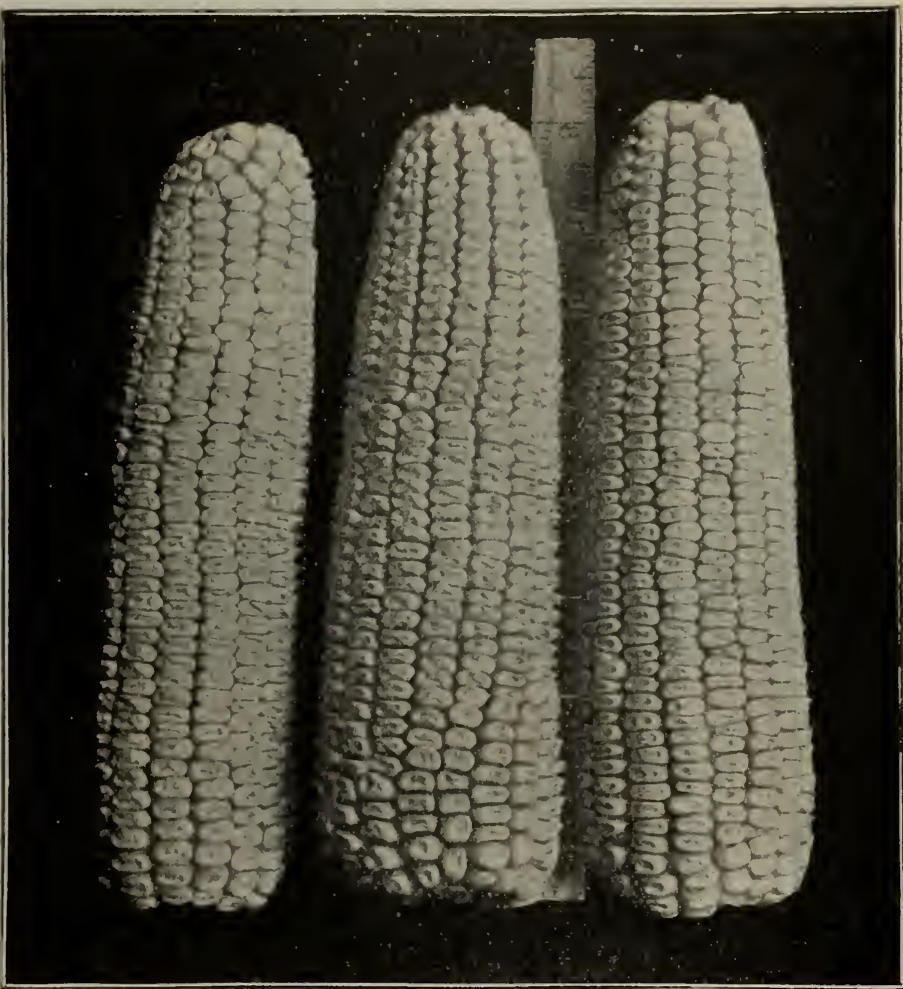
raise." Later Prof. Moore reported the yield 75 bus. per acre for his whole 22 acres.

Our stock of Silver King is fine. It was grown by members of the Wis. Ex. Association in Wal. worth, Jefferson, Dodge and Fond du Lac counties.

Prices-On the ear: Bu., $\$ 3.00 ; 5$ bus. at $\$ 2.85 ; 10$ bus. at $\$ 2.75$. Shelled: $1 / 2$ pk., 50c; pk., $85 \mathrm{c}$; bu., $\$ 2.75 ; 2 \frac{1}{2}$ bus. or over at $\$ 2.50$.

EXTRACTS from REPORTS of GROWERS Of SILVER KING CORN.

Fred A. Speerschneider, Brown county: "Outyielded any we ever had, 75 bus. to the acre.'

B. F. Snyder, Juneau county: "I got about 130 baskets of ears to the acre."

Arthur F. Rosenow. Waukesha county: "Our yield the past year was 60 to 70 bushels shelled corn per acre. It seems to be the coming corn for us."

H. O. Aavang, Iowa county: "Stalks averaged 9 feet in height and very leafy. Yield estimated fully 60 bushels shelled corn from three-quarters of an acre."

Otto Haass, Waukesha county: "Yielded 123 baskets to the acre, by far the largest yield of dent corn we ever raised."

M. Gallagher, Juneau county: "The yield was 95 bushels to the acre, which was nearly twice as much as the home variety. It was a very great success with me."

O. C. Heidemann, Manitowoc county: "Almost every stalk bore as many as two ears; at least four-fifths of them did.'

\section{EARLIEST YELLOW DENT (Wisconsin No, 8).}

\section{For Northern Wisconsin and Similar Latitudes.}

Another new variety developed at the Wis. Experiment Station that came originally from Minnesota. Earlier than any other we offer, and probably the earliest dent corn grown. It fully matures on the shores of Lake Superior and will get ripe anywhere in Wisconsin. Ears average 7 to 8 inches in length, with good length kernels, very uniform in type and color, with remarkably well. filled tips. It grows a medium-sized stalk with a good leaf development, and with practically no

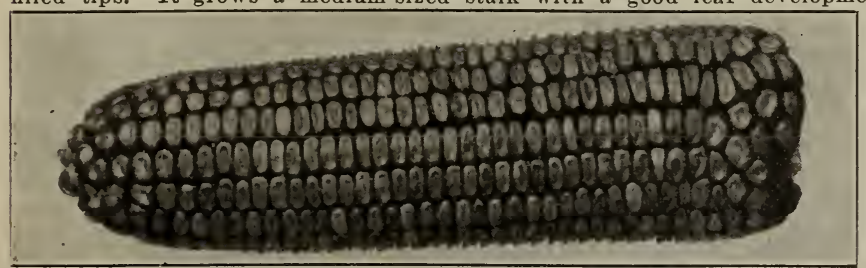

An Average Ear of Wisconsin No. 8 Corn. barren stalks. $O$. $R$. Fraunheim of Washington county reports less than one-half per cent barren stalks. He secured a yield of $681 / 2$ bushels of shelled corn per acre. A great record for an extra early. We have a choice lot of this corn grown by a member of the Experiment Ass' $n$ in Fond du Lac Co. Prices, same as for Silver King.

(See pages $30,31,32$ and 33 for Standard Varieties of Corn.) 


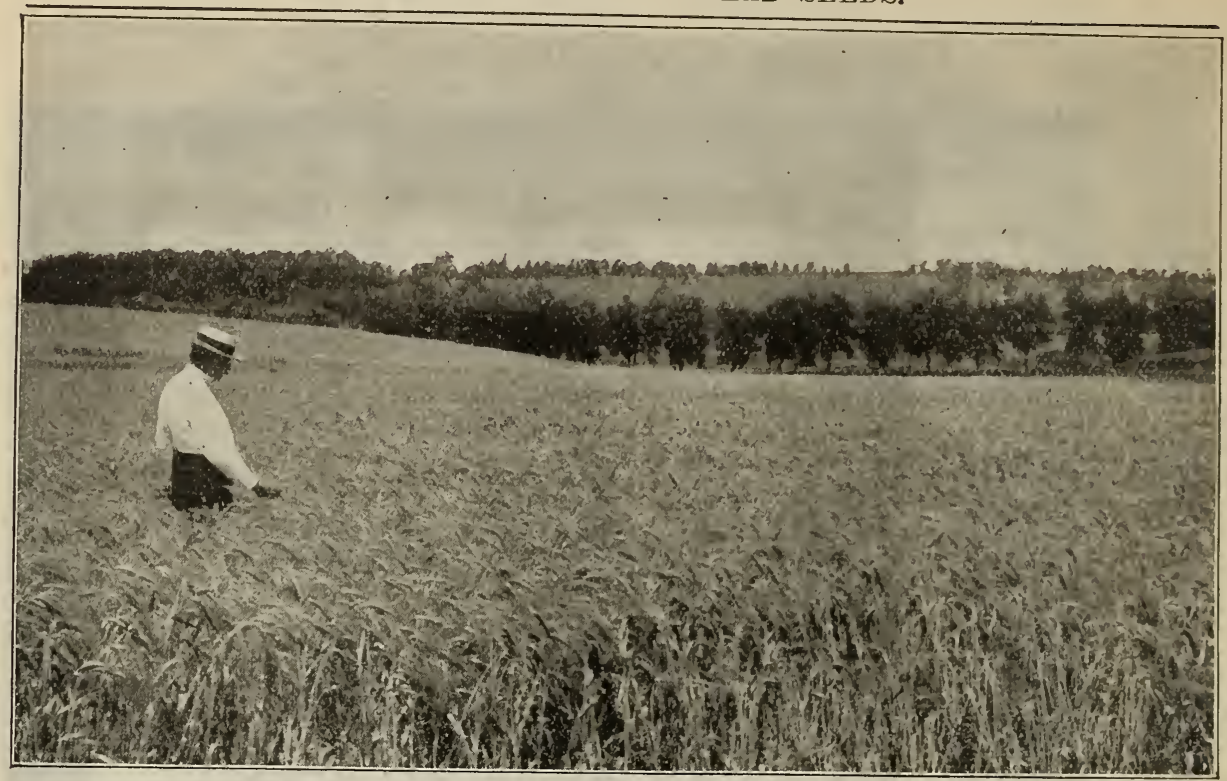

Prof. Moore Inspecting Field of Oderbrucker Barley on the Wis. Experiment Farm, 1906. Yield of this field, 55 bushels per acre. Average yield of Oderbrucker at the Station for 8 years, $531 / 2$ bushels per acre.

\section{ODERBRUCKER BARLEY (Wis. No. 55). WISCONSIN'S WONDERFUL NEW BARLEY.}

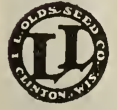

Wisconsin is a great barley state and enjoys the honor of having developed and sent out the most famous and most valuable variety to be found in all the barley-growing sections of the United States, the Mandscheuri. Now we have a new one to offer, which, like the Mandscheuri, gets its send-off from the Wis. Experiment Station and which Prof. Moore declares is superior even to that variety, yielding 5 to 10 bushels more per acre.

History.-In 1898 the Wis. Experiment Station received from the Ontario Agricultural College 5 pounds of barley known as Oderbrucker. This barley had been obtained from Germany and grown several years on the college farm at Guelph, previous to being secured by the Wis. Station. From this beginning the barley has been grown on the Station farm 8 years now, the plants being watched closely each season and only the best selected for seed for the following season's crop. This test has been carried on in comparison with 25 other varieties, and the statement made now by Prof. Moore is that "it is the most satisfactory barley from all points of view grown on the Station farm." Last spring 500 bushels of this high-grade barley were given to 250 members of the Wis. Experiment Association and acre tests made in every county in the state. These men are all very enthusiastic over the new barley and have made some wonderful reports. Read what some of them say on the next page.

Description.-Oderbrucker is a stiff-strawed, heavy-yielding, six-rowed, bearded variety. It is about the same as Mandscheuri in season, manner of growth and general appearance, but has a plumper kernel and is heavier. Many of the Experiment Association members speak of these qualities as well as others. Prof. Moore says that for "stiffness of straw and rust resistance it is superior to any variety on test." It has a protein content of $15 \%$, or nearly double the amount of protein found in other varieties. This makes it an exceptionally valuable feeding barley, a very important point when it is considered that leading farmer's and stockmen, especially here in Wisconsin, are appreciating more and more the value of barley as a feed for all kinds of stock, horses as well as cattle.

Conclusion.-Our conclusion is that if you raise barley at all you onght to have seed enough of the Oderbrucker to sow all your acreage this year, and it will pay you well to secure it. What is your conclusion? If it yields 5 to 10 bushels more per acre you will get your seed money all back the first year twice over. We have a big stock of seed to offer. In fact, we pretty nearly control it all. It seems that two or three favored members of the Experiment Association were allowed to grow this barley previous to last year and so had quite a large stock on hand. We have secured nearly all that these men had to spare besides growing a lot here ourselves. So everybody send in your orders for seed of this, the best barley on earth.

Prices-By mail: 2-oz. pkg., 10c; lb., 30c. By freight or express: Lb., 20c; $\frac{1}{2}$ pk., $35 \mathrm{c}$; pk., 50c; bu. (48 lbs.), $\$ 1.50 ; 2$ to 10 bus. at $\$ 1.35 ; 10$ bus. or over at $\$ 1.25$. 
WHAT THEY SAY ABOUT ODERBRUGKER BARLEY.

Extracts from Reports of Members of the Wis. Experiment Association who Grew the New Barley Last Year.

Alfred F. Orth, Grant Co.: “Best barley around here. Have sold all the seed I have to spare to the neighbors.'

Otto C. Heileman, Manitowoc Co.: "Coarser in straw than the common barley, and therefore does not lodge so easy; also yields more per acre and has a plumper kernel.'

Francis E. Ebert, Monroe Co.: "We think the barley very fine; nice plump kernels. The finest threslied around here this fall.

J. G. Keosten, Waupaca Co.: 'The finest barley I ever saw.'

Henry Whitehead, Monroe Co.: "Outyields any I ever had."

Peter F. Neis, Brown Co.: "I weighed 8 bushels as it came from the machine, and they averaged $571 / 2$ lbs. to the bushel.'

Henry C. Aavang, Iowa Co.: "Four days earlier than the other variety we had, and of better quality.'

Frank Erstman, Sheboygan Co.: "Threshers say they never saw barley so easy to beard, and all farmers pronounce it the finest sample they ever saw.'

Wm. Kneip, Waupaca Co.: "Far ahead of any other kind raised around here in yield per acre, and it stood up while other kinds lodged.'

F. E. McKitchen, Crawford Co.: "I think Oderbrucker barley is the coming barley for Wisconsin. It is of good quality, shows little inclination to rust, and stands well, as it has a very stiff straw.

Wm. A. Parsons, Jefferson Co. : "I consider Oderbrucker barley an exceptionally good barley, and the man who threshed it claimed that it was the best that had gone through their machine.'

D. W. Collins, Kewaunee Co. "Stood up better and gave better satisfaction than any I ever grew.'

Ezrs Peters, Walworth Co.: "Plumper than other barley and weighs more per bushel.'

Kaspar Johnson, Trempeleau Co.: "Way ahead of the average barley grown here."

Sherman Roethel, Manitowoc Co.: "Ripens early, stands up well and stronger in straw than Manshury.'

Louis H. Frischer, Sheboygan Co.: "Did exceedingly well, had it on rich soil, but it did not lodge. Kernels plump and a heavy yielder.'

Hv. N. Peterson, Calumet Co.: "I think the Oderbrucker the coming barley for Wis, farmers.'

Arthur Cochur: "On same land as our other barley heads over one-third longer and larger. Also the straw was stronger and stood higher.'

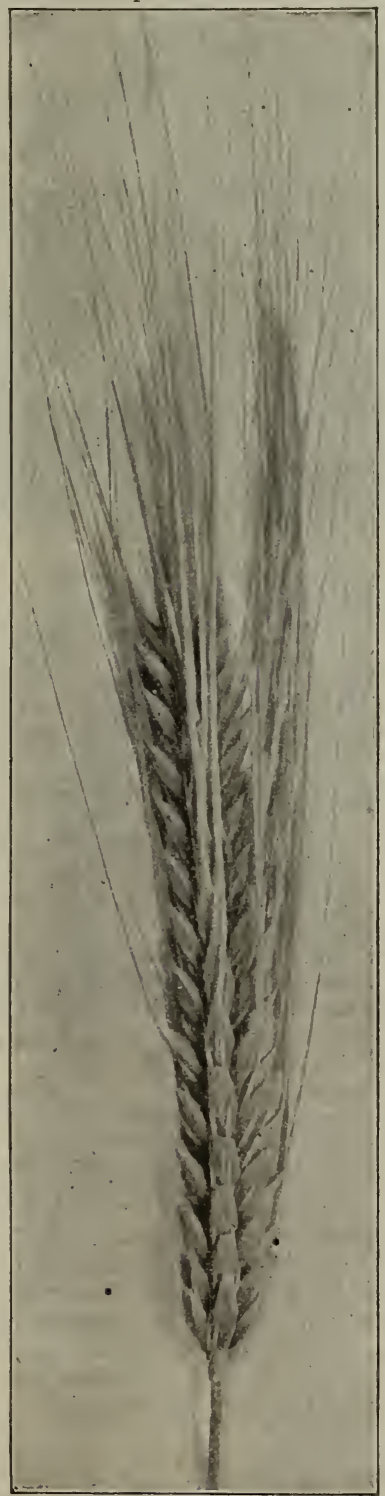

Head of Oderbrucker.

Burt F. Snyder, Juneau Co.: "I raised the Hanna barley and also another common variety right along by the side of the Oderbrucker, and consider the Oderbrucker far better than either of the others. I expect to sow all that kind next year.'

Geo. F. Blanik, Kewaunee Co. "Far ahead of the common vari ety as to standing qualities and a great deal heavier bearer.

Otto Toepfer, Dane Co.: "The straw is stiff and stands up fine with long, heavy heads of niceshaped kernels.

Leon T. Pope, Dane Co.: "Think there is a great future for it, and so far as. I am concerned it certainly fills the bill. The straw seems very resistant to windstorms, and barley will thrive on exceptionally rich soils. At threshing time I received many compliments on the plumpness and weight of the barley.'

Edward E. Straka, Manitowoc Co.: "I think it is the best barley that was ever grown on our farn. It stood up well. The straw seems to be much stronger and resistant to rust. Yield also better.'

Arthur H. Irnig, Clark Co.: "I think Oderbrucker barley the best we ever grew. It has a very stiff straw, which enables it to stand up under conditions where other kinds would lodge.

(From the Wisconsin Agriculturist of Oct. 18, 1906.)

Congress Aids in Barley Test.

The breeding of high-grade grains, and particularly of barley, one of the most important branches of work carried on by the Wis. Agl. Experiment Sta tion at the University of Wis. consin has just received a special impetus through arrange ments which have been made for co-operation between the station and the Department of Agricul ture at Washington. The appro. priation of $\$ 4,000$, made by the last Congress, will be used to continue and enlarge the work which for eight years has been conducted successfully in Wisconsin.

"Experiments in the breeding of grains and forage plants for the betterment of farm crops have been carried on at the Wisconsin Agricultural Station for eight vears past," said Prof. R. A. Moore, agronomist at the College of Agriculture, who has just returned from Washington where he made arrangement for the cooperative work

"A barley which was bred in this way," Mr. Moore continued, "is known as the Oderbrucker or Wisconsin No. 55. It has given a yield of from five to ten bushels an acre more than was

A. J. Blakely, Winnebago Co.: "Nearly double the yield of common barley and stood up perfectly."

Jno. H. Raffers, Brown Co.: “'Made a large yield and has done better than any other variety in this locality. Am much pleased with the variety."

A. C. Grumstad, Iowa Co.: "One of the finest barleys I have ever seen. It stood up well and does not rust. Grains plump and well developed.' secured from other varieties placed on trial at the same time for comparison. The estimate is made from reports sent in from 233 menbers of the Wisconsin Agricultural Experiment Association, who are testing this particular variety of barley. It is grown at present in 50 counties of this state, as well as in six in Illinois and three in Iowa, and has proven not only a good yielder, but also of high protein content, making it an exceptionally fine feeding barley.'

Other Varieties of Barley, pages 34 and 35 . Speltz, page 38. 


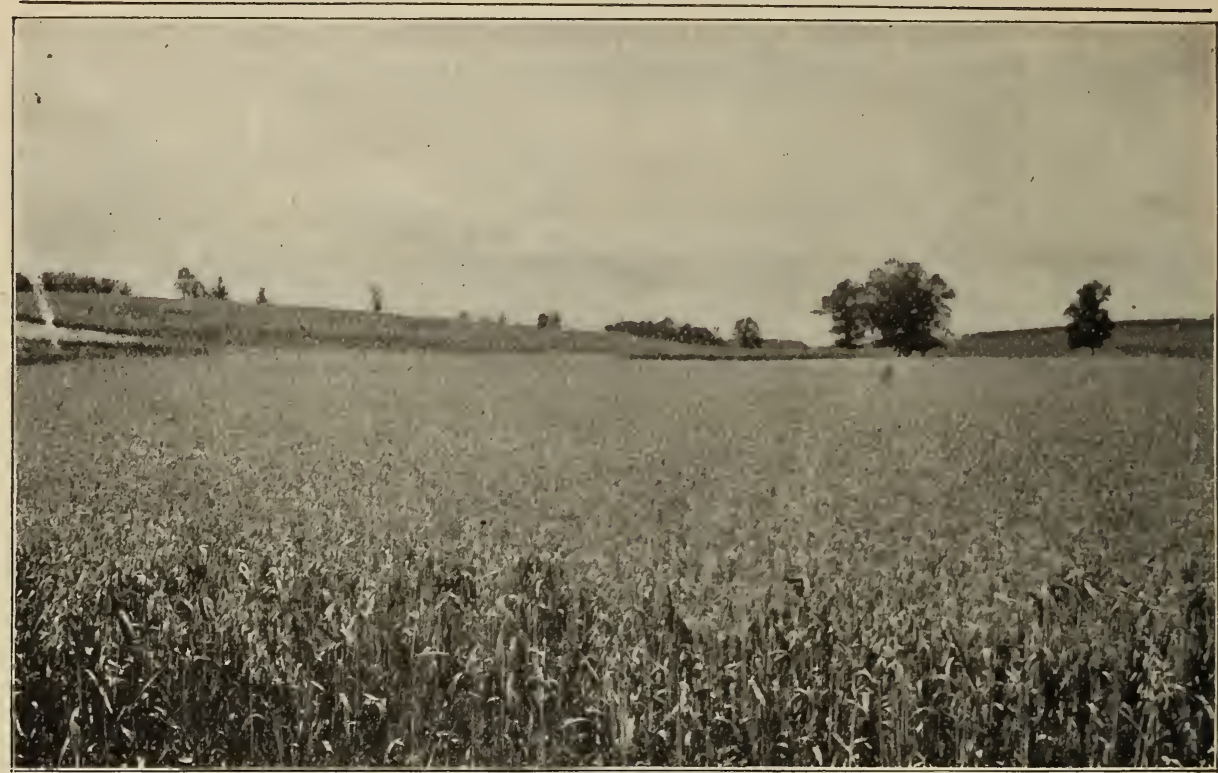

Field of Swedish Select Oats on the Wisconsin Experiment Station Farm, 1906.

\section{SWEDISH SELECT OATS (Wis. No. 4). THE OAT OF THE CENTURY. (See Front Cover.)}

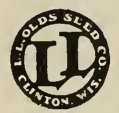

We almost feel like saying there is only one oat in America today and that one the Swedish Select. The State Experiment Stations are placing it ahead of everything else and the U. S. Dept. of Agriculture itself says, "Now probably the best American oat.", Everybody wants them. Wherever oats are grown-north, south, east and west-farmers everywhere are ordering Swedish Oats. We were the first to catalogue them three years ago, and now every seed house in the country is after them. The first year we sold 4,000 bushels, the next year 6,000 and last year 10,000 . This year will be the biggest yet. Order of us and get the genuine, as we are the original introducers. We have an immense stock, pure, clean and bright, grown mostly on the new lands of Northern Wisconsin.

The seed came originally from Russia, having been brought from there by Prof. M. A. Carleton, of the Agricultural Department, Washington, in 1898. Prof. Carleton sent the oats, with others, to Prof. R. A. Moore, Agronomist at the Wis. Agricultural College, who, after thoroughly testing them for four years with 36 other varieties, found them "the most satisfactory of all.",

Prof. Moore, in the regular Experiment Station report for 1905, thus speaks of them: "The Swedish Select (Wis. No. 4) has been grown generally throughout the state during the past three years and is the most popular variety of oats now grown. The Swedish Oats are especially well adapted for the upland soils and seem to do better on poorer grades of land than any, other variety tried. Their great root development renders them exceedingly resistant to droughts."

The fact of the matter is, Swedish Oats fill the bill everywhere. They seem to be just what is wanted in a first-class oat-pure white in color, very plump, short and thick, with thin hull, medium early in season, very strong and vigorous in growth, with stiff, coarse straw, unusually heavy in weight and the best of yielders.

To sum up, the following are reasons why Swedish Oats are "the best":

First-They outyield all others. Nearly every one who tries them testifies to this.

Second-They are one of the heaviest. 36 to 42 pounds per measured bushel is the way they run. Most all farmers speak of the unusual weight.

Third-Stiffness of straw. "The straw is coarse, and is noted for its stiffness and power to withstand lodging," Prof. Moore says.

Fourth - Fine appearance. They are pure white in color, large, thick and plump. None handsomer. The heads are large, upright and bushy.

Fifth-Thinness of hull. They are nearly all meat. This is what makes them valuable as a feeding oat. Sixth-Great root development. "This is characteristic of the Swedish oats, which enables them to resist drought better than any other variety tested." So says Prof. Moore. Prof. Shepard, of the South Dakota Station, says: "They are the best drought-resister of all our new plants." Seventh-Adaptability. The best success is on clay soils, but they have been sown on all soils, including sand, and are most satisfactory everywhere.

Eighth-Earliness. They are the earliest, we think, of all large, heary-yielding oats.

Ninth-Freedom from rust and smut. They are less liable to sinut and rust than most any other oat. Our stock is from treated seed and practically smut-free.

Tenth-New Blood. Get the newest and best while you are at it.

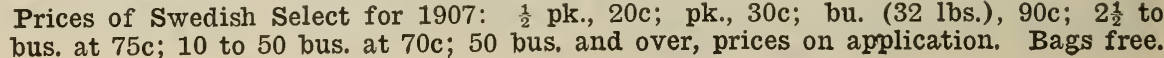




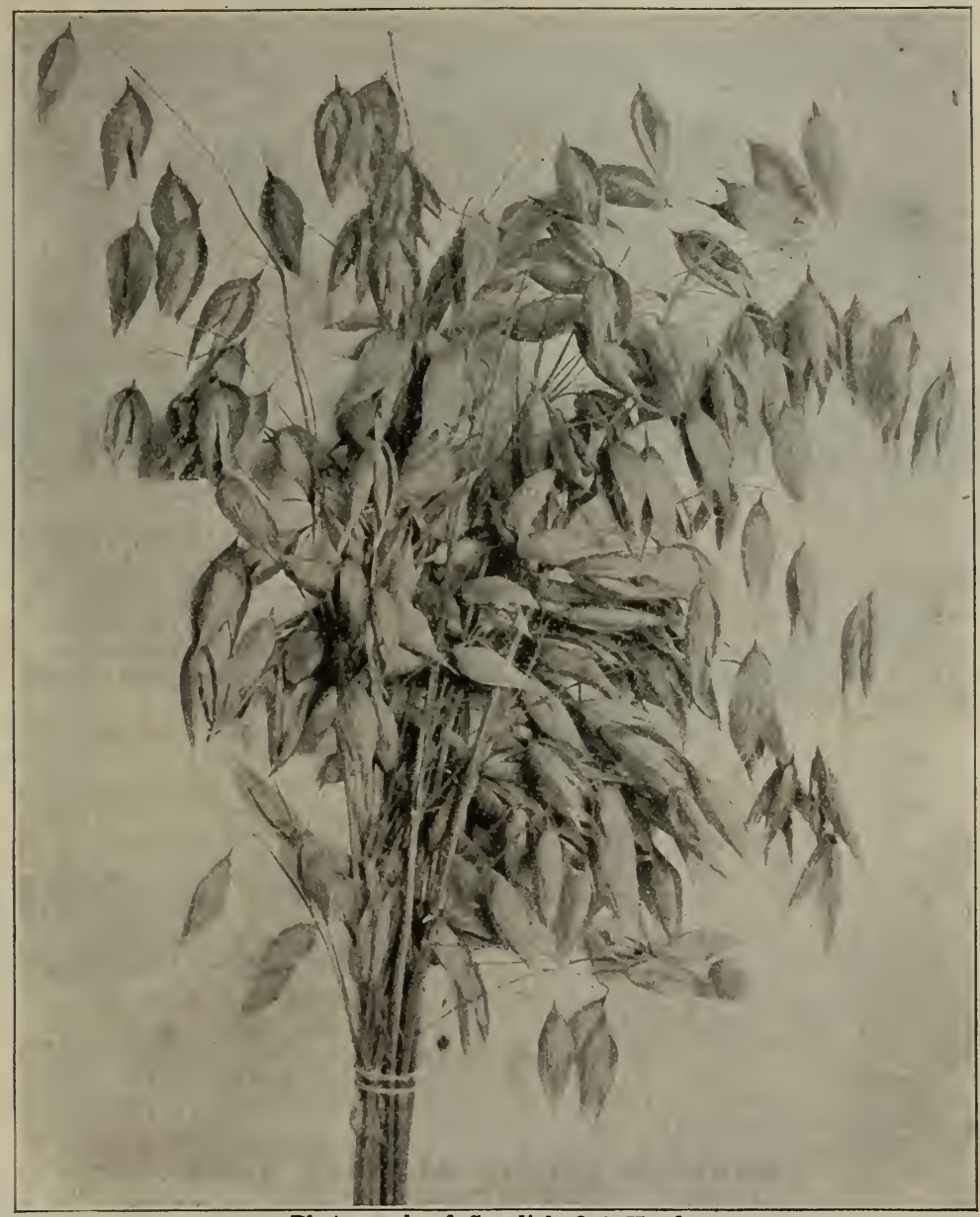

Photograph of Swedish Oat Heads.

\section{WHAT THEY SAY ABOUT SWEDISH OATS.}

$172^{1 / 2}$ BUSHELS ON TWO ACRES.

Christ Larson, Pierce county, Wis.. Feb. 12 , 1906: "Your Wis. No. 4 (Swedish Select) Oat is a dandy. I had 2 acres last year and from those 2 acres I threshed $1721 / 2$ bushels."

WEIGHED 42 POUNDS PER BUSHEL.

G. A. Carper, Illinois, Feb. 8, 1905: "The Swedish Select Oats I bought of you last spring were fine. I sowed them on the poorest ground I had, so the yield was not very big, but the weight was there, as they weighed $42 \mathrm{lbs}$. to stroked bushel. Pretty hard to beat, wasn't it?"

105 BUSHELS PER ACRE AND EARLY.

Grace Park Farm, Avon, Colo.: “"The most satisfactory variety tested' (about 36 in all), says the Wisconsin Experiment Station.

"These oats were bought on the foregoing recommendation. The first year's trial has been satisfactory, 105 standard bushels per acre of fine grain and early - in fact. the earliest oat ever grown at Grace Park Farm. Harvested the last week in August."

E. D. Ebert, Monroe Co.. Wis.: "Swedish have rery strong straw, standing about four and one-half feet high. They stood up well when other oats (the Silver Mine) on poorer soil lodged. The yield per acre was 60 bushels. The oats are very plump and ripen from three to six days sooner than other oats."

(See page 36 for Other Varieties of Oats.

\section{BUSHELS PER ACRE.}

E. E Cowles, Narch 12, 1906: "The Swedish Select. Oats I got from you two years, ago yielded last year 94 bus. an acre on 8 acres.' GOT THE BLUE RIBBON.

Ernest Knoop, Will Co., Ill., Feb. 27, 1906 : "Your Swedish Select Oat" is O. K. I had some at our fair last year and got the blue ribbon."

Wm. L. Illian, Sheboygan Co., Wis.: "I hare now grown the Swedish Select Oats for three years. With us they hare yielded as high as 70 and 80 bushels per acre. It outyields anything that I have ever seen. It ripens early, and so is not so apt to get rusty. The heads are always large, upright and very bushy, kernels thick and plump, which gires the oats a fine appearance."

SURPASSES ALL OTHER VARIETIES.

H. J. Renk, Dane Co., Wis.: "With us we have found it strong and vigorous as a plant, haring a dark green, healthy appearance. I well remember the first year we grew it along beside our then best oats. As soon as they were up 4 to 6 inches any one could see the difference 80 to 100 rods off. The Swedish Oats looked thicker, more rigorous and taller, while our own looked thin, shorter and sickly, haring a light yellowish appearance. I expect they were ed of themselves. At least the havelder it surpasses all other varieties we ever grew." reat your Seed for Smut; page 36 tells how.) 


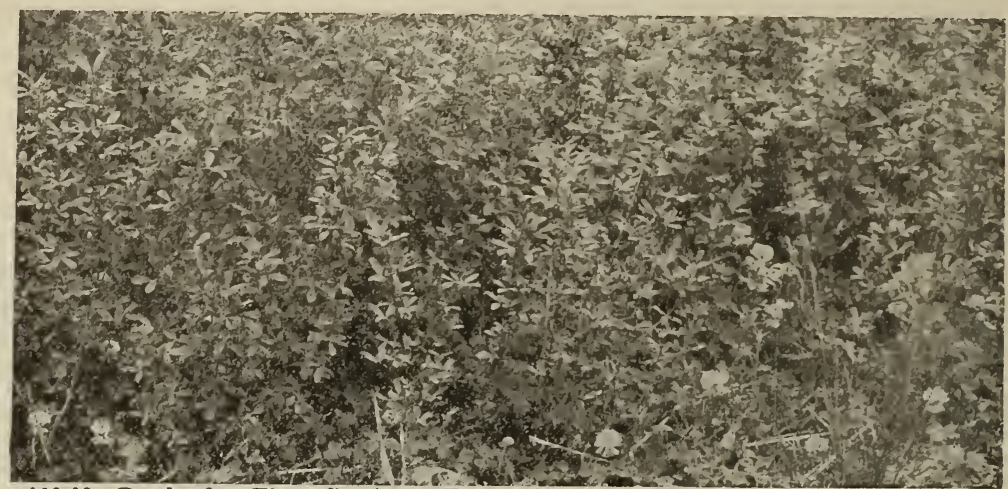

Alfalfa Ready for First Cutting.-Farm of Howard Green, Waukesha Co., Wis.

\section{ALFALFA. Most Valuable Plant for Northern Farmers.}

Alfalfa is not exactly a new thing, but its great value is only just beginning to be appreciated by most farmers in the north. It has been found that it can be successfully grown in every state in the Union and on all soils. It is superior even to red clover for enriching the soil, as it has a greater root development (see illustration on page 43), it is hardier than clover and its feeding value for all kinds of stock can hardly be overestimated. Prof. Moore says: "Alfalfa hay, if properly cared for, is equal, pound for pound, to the best wheat bran in feeding value." Now we will let Gov. Hoard talk. He knows all about alfalfa, as he has had a lot of experience with it. The following are extracts from his address at the last meeting of the Wis. Experiment Association, February, 1906:

"No other question is before the Wisconsin farmer that is of deeper importance to his material welfare than this question of alfalfa.

'Last year I placed 180 tons of alfalfa hay in my barns, grown on 35 acres, every ton of which is worth in actual feeding value from three to four tons of timothy hay, the best timothy hay that you and I can grow.

"Just a minute, look at these figures, timothy hay standing about 3 per cent protein; alfalfa, 11. Now, what does that mean? Alfalfa producing 5 tons to the acre with me and timothy two. What does that mean?

"Alfalfa and corn silage form an almost absolutely perfect ration.

"I maintain my brood sows upon nothing but alfalfa hay.

"It will grow upon any kind of soil.

"I would rather risk it in the vicissitudes of a Wisconsin winter and summer season than red clover twice over.

"Do not overseed with your nurse crop. One bushel of barley to the acre has been my rule.

"Commence cutting when you see the very first blossom.

"No live stock man can afford to be without this great forage plant."

\section{AMERICAN-GROWN ALFALFA SEED.}

The seed is the important thing with alfalfa. A large per cent of the seed offered for sale comes from Europe. It is cheaper than American grown, but not as desirable. It is not as hardy and is apt to be adulterated with Yellow Trefoil, Burr Clover, Dodder, etc. The seed that we offer has been analyzed by the U. S. Dept. of Agriculture, and they report to us only " $1-10$ of one per cent foreigil seed, a trace each of sweet clover and lamb's quarters,' so that our seed is practically pure. It is all Utah grown. Seed from Kansas and Colorado and even from Nebraska is not recommended for the northern States, as it is not hardy enough. To quote from a letter from Wis A l. College, dated Nov. 21, 1906: "In reply to your question concerning Kansas or Nebraska grown seed, would say that we do not think it suitable for best results in Wisconsin. We find that Montana, Idaho and Utah grown seed is much better for our purposes.'

Prices-Choicest Utah grown Seed-by mail: Lb., $35 \mathrm{c}$; 3 lbs., 90c. By freight: Lb., 25c; $1 / 2$ pk., $\$ 1.35$; pk., $\$ 2.50$; per bu. of $60 \mathrm{lbs}$., present price, $\$ 9.00$; bags extra at $18 \mathrm{c}$. Sow $20 \mathrm{lbs}$. of seed per acre.

(Alfalfa prices are subject to change. Write us for special prices when ready to buy. Samples free.)

TURKESTAN ALFALFA.

A comparatively new variety of alfalfa from Central Asia. Supposed to be hardier than the ordinary alfalfa, although experiments have not fully proven this. In Turkestan, where the seed grows, the winters are very cold and the summers dry and hot, so it is able to withstand the greatest extremes of heat and cold. "The seed we offer is choice recleaned, the best we can secure. This Turkestan Alfalfa must not be confounded with ordinary European grown alfalfa, such as we refer to above.

Prices, same as for our American Alfalfa.
FREE SAMPLE COLLECTION. OLDS' SEED SPECIALTIES.

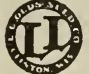
We furnish small samples free on application of any of our varieties of field seeds, but in order to save time we have put up a large number of Special Collections of Samples. This collection consists of ten varieties of what we consider Our Leaders. We expect a great demand for all of them, and in each case have a large supply of the same stock that the sample is taken from. This collection will be mailed absolutely free to all who apply for it. We first adopted this plan two years ago, sending out in response to requests that year several thousand free collections. Last year we followed the same plan, and judging from the requests received, our customers like it. WVe can afford to do it, because it brings the orders. The collection this year is as follows:

Oderbrucker Barley, described on page 4.

Swedish Select Oats, described on page 6 .

Clark's Yellow Dent Corn, described on p. 2.

Silver King Corn, described on page 3 .

Kubanka Durum Wheat, described on page 37. White Hulless Barley, described on page 35. Alfalfa, Utah Grown, described on page 8.

old Gold Red Clover, described on page 42 .

old Gold Alsyke, described on page 42 .

Home Grown Timothy, described on page 43 . 


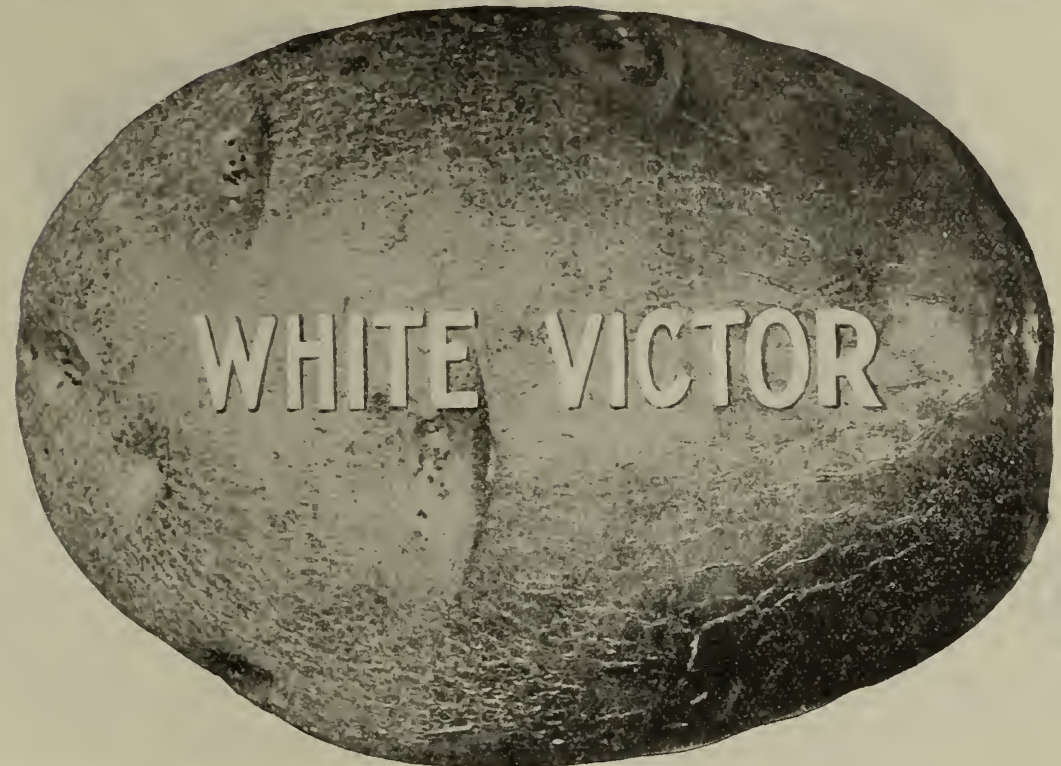

WHITE VICTOR.

Most Profitable of All Varieties for Main Crop.

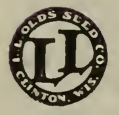

Our great 1905 introduction. This potato in two years' time has jumped into prominence, and now is widely sought after. "There is a reason."

First-Productiveness. The greatest of all tests for a potato is the yield test. We first planted White Victor in 1904. That year it outyielded everything on our list except Pat's Choice. In 1905 our largest grower here, Mr. Fred Wobig, had White Victor and Pat's Choice planted side by side under exactly the same conditions. White Victor not only shot ahead of Pat's and yielded more, but it beat everything else in the field, including Carman No. 3. This last season every one of our growers who had White Victor reported it ahead of everything else, and with Mr. Wobig it yielded one-fourth more than Pat's Choice in the same field. Mr. J. Reynard Lawrence, the Massachusetts specialist, tested it together with a lot of others, including some of our best vielders, and he reported that it outvielded them all.

Second-Keeping Qualities. Right here White Victor beats everything we ever saw. It remains firm and hard and fine for cooking way into the summer and even almost up to the time late potatoes come again, a year after it is dug.

Third-Handsome Appearance. An all-round potato must be a good looker. White Victor is just that. Note our illustration. It is a half-tone, as are all our potato cuts, with one exception, and shows an average tuber just exactly as it is. The skin is white or creamy-white in color, well netted and russeted, with few and shallow eyes, and the shape just right, a little longer one way than the other.

Fourth-Strong Vitality and Large Growth. In our description of White Victor two years ago we spoke of this as "its most striking characteristic." There is never any half-stand with fields planted to White Victor. Every cutting grows and makes a strong growth. The field illustration on the next page gives a little idea of the strong, even growth of vine. Under date of Aug. 20, 1906, we made the following notes on the field of one of our growers, Mr. Leo Voltz: "Splendid, large growth. Ground entirely covered. Rows can hardly be distinguished."

Fifth-Good Cooking Quality. White Victor is good when first dug, and it gets befter as the season advances. For a spring potato it is hard to beat for quality.

Sixth-Uniformity. Although such a great yielder and strong grower, there are seldom any extra large, overgrown tubers so common in some main-crop varieties.

Seventh-Desirable Season. White Victor is medinm in season, not real late. It is a week earlier than Pat's Choice and earlier than Sir Walter Raleigh and. Carman.

To Sum Up.-For an all-round potato, a good looker, big yielder and money-maker, we call White Victor ahead to date. Get started this year sure.

Prices of White Victor for 1907-By mail, postpaid: Lb., 30c; 3 lbs., 65c. By freight or express: Lb., 20c; $\frac{1}{2}$ pk., $40 \mathrm{c}$; pk., 60c; bu., $\$ 1.75 ;$ bbl., $\$ 3.75 ; 5$ bbls.. at $\$ 3.60 ; 10 \mathrm{bbls}$. at $\$ 3.50$.

(Our potatoes are always sold by weight. A bushel is 60 lbs., and a barrel $2 \frac{3}{4}$ bushels or $165 \mathrm{lbs}$. Not less than one pound sold of any variety.) 


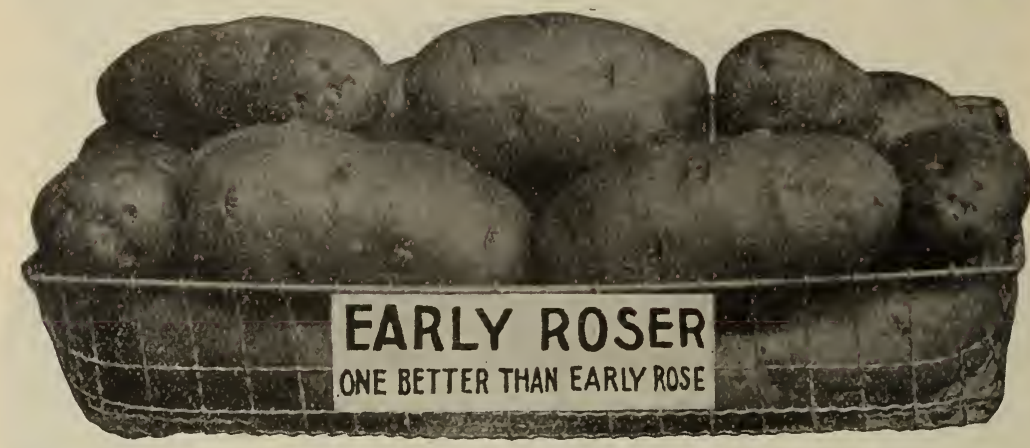

EARLY ROSER.

\section{ONE BETTER THAN EARLY ROSE. HEAVIEST YIELDING EARLY.}

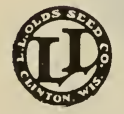

We introduced this potato in 1904 as a successor to Early Rose. We named it after the originator, Mr. E. L. Roser, of Ohio. We also considered this an appropriate name because better than Early Rose. Early Rose was long considered the best early potato in cultivation, but it finally had to be discarded. Here is something equal to Early Rose at its -best and a heavier yielder. We do not think it is quite as early as Early Rose, but otherwise it is about the same. This is its history:

In $1901 \mathrm{Mr}$. Roser mailed us two small tubers for testing. After testing the potatoes carefully two seasons we were so well satisfied that we bought the entire stock, which was only about 10 bushels, with exclusive rights. Mr. Roser says:

"It is a seedling of ' 93 and has yielded well every season. Last year it yielded as well as Carman No. 1 and Seneca Beauty. It grows a heavy stalk, which stands a great deal of dry weather. I never tested a potato of finer texture, and it is as mealy a potato as it can be and not fall to pieces while cooking. I believe it will become valuable, as it has quality good enough for any person.'

Mr. Roser emphasizes the fine quality and texture of the potato, and our experience confirms what he says, but the thing we have noticed most is its tremendously strong growth and heavy yielding qualities. For four years it has outyielded all other earlies in this section. It loes not seem to blight as other earlies do, but keeps right on with its strong, healthy growth until the vines die naturally. Last year we could not supply the demand for Early Rosers, although we had a big stock. Lots of people wanted them. It will be the same this year. We have a good many, but better order early. Remember, almost an Early Rose over again for appearance and fine quality, and ahead of all other earlies in yield.

Prices-By mail: Lb., 30c; 3 lbs., 65c. By freight: Lb., 20c; $\frac{1}{2}$ pk., 35c; pk., 50c; bu., $\$ 1.60$; bbl., $\$ 3.50 ; 5$ bbls. at $\$ 3.35 ; 10$ bbls. at $\$ 3.25$. Second size, see page 29 .

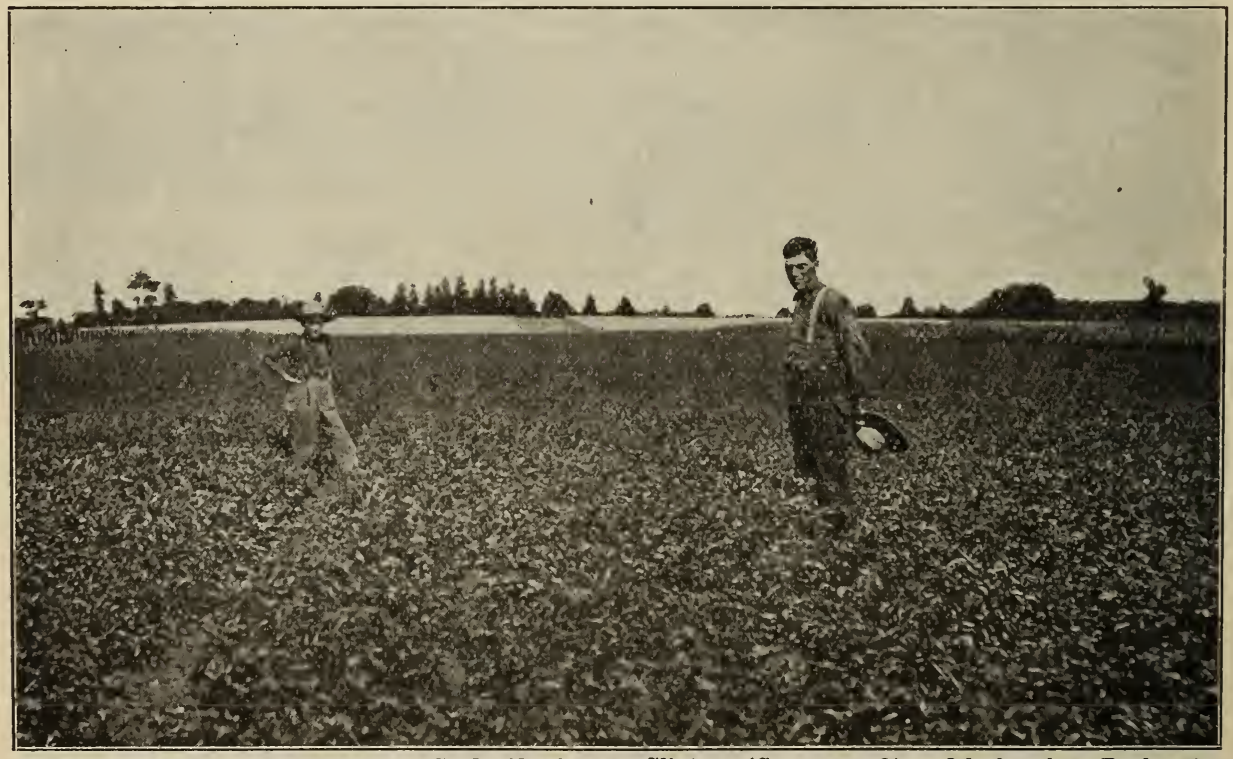

Field of White Victor grown by C. L. Newhouse, Clinton (See page 9). Oderbrucker Barley in the distance. 


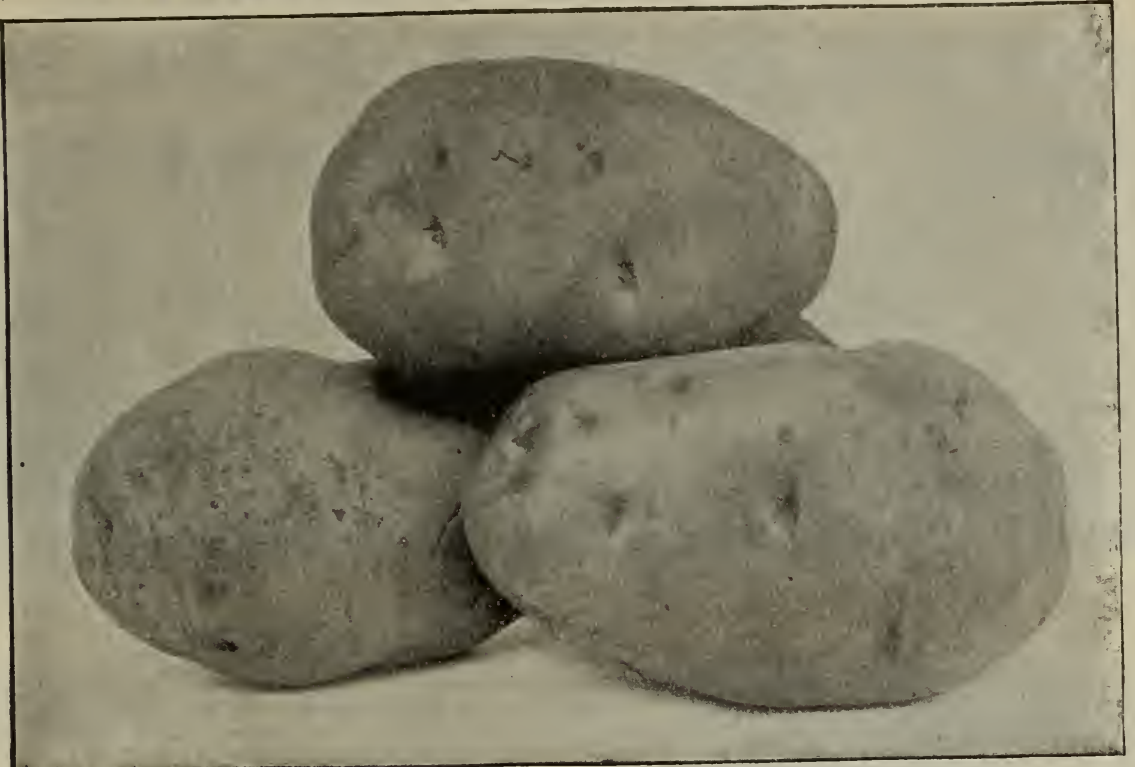

Twentieth Century Potato, a Famous 1906 Introduction.

\section{TWENTIETH CENTURY.}

This new potato was introduced last year by a well-known western New York firm. The introducers claim that it is "the strongest growing and most vigorous potato of our time." It is a pure white, round to oblong potato, but somewhat irregular in shape, with rather deep eyes; skin well

netted, excelfent in quality, season late. it was destined to become popular, and we had them planted here for us by one of our best growers. They came up with a fine, even stand, made an unusually large, strong growex, gotion of White Banner right by the side of them in the same field, and, with the possin maturing, however, as Victor, they outyielded everything grown in this section. They were late in matu potato. Would it seemed as if the vines never would stop growing, and they are

consider them a specially valuable sort for light and sandy soils.

Prices-By mail: $1 \mathrm{~b}$., $30 \mathrm{c} ; 3 \mathrm{lbs}$
$\$ 1.75$; bbl., $\$ 3.50 ; 5$ bbls. at $\$ 3.35$.

\section{OLDS' NEW 1908 POTATO.}

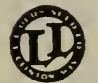

Next year we intend to introduce a new main-crop potato, a seedling that we have been working on for some thing. We want to get a lot of customers to test this potato for us in 1907, and we will send a single average tuber to each one of our customers who orders potatoes of us thing is that only 10 cents. Not more than one potato will be sent to a person, and the understanding with this every one agrees to report on it next fall. This is

\section{NOROTON BEAUTY (QUICK LUNGH).}

A famous extra early variety introduced at high prices and with strong claims in 1905 by J. M. Thorburn \& Co., original in1905 by J. M. Thorbur Hebron, Rural New troducers of Beauty of Hos. 1 and 3 . The same year Uncle Gideon's Quick Lunch was in troduced by Burpee, and it is generally troduced now that the two varieties are identical.

Noroton Beauty is a very pretty potato and of extra quality. The color is white, slightly rusted, and splashed more or less with pink. It grows a rather small, squatty wine, with broad, light green leaves and pink vine, with broad, light green leath is similar blossoms. Its manner of growth is similar to that of Triumph, vines rery bushy and compact. Alth satisfactory, for early ripennot been easily way ahead of everything else. ing it is easily way as as the earliest of anyWe recommend it as the earliest of anyways be given rich soil and high culture, wa treated carefully for blight. Our stock this this year is quil the prices we are making. will go fast at the prices we are making. Two years ago they sold at $\$ 24$ per bushel.

Prices-By mail: Lb., $40 \mathrm{c} ; 3$ lbs., $85 \mathrm{c}$.

$\$ 1.00$; bu., $\$ 3.00 ; \mathrm{bbl}$., $\$ 6.50$.

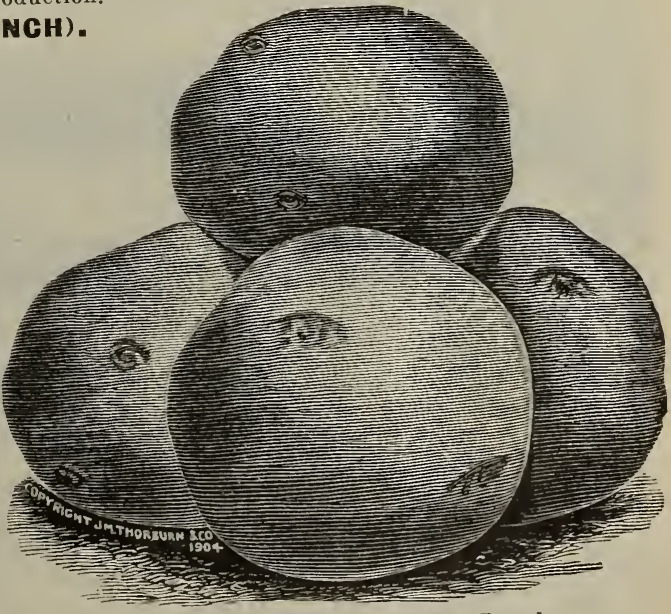

Noroton Beauty, or Quick Lunch. 


\section{NEW VARIETIES VEGETABLES.}

Sce Back Cover Page for illustrations in Natural Colors. The following seven pages embrace the best of the Newer Varieties - those that we know from actual test, possess special merit.

See Pages 45 to 68 for older and standard varieties; 69 and 70 for Collections, and pages 71 to 79 for Flower Seeds, Bulbs and Plants. Order by number.

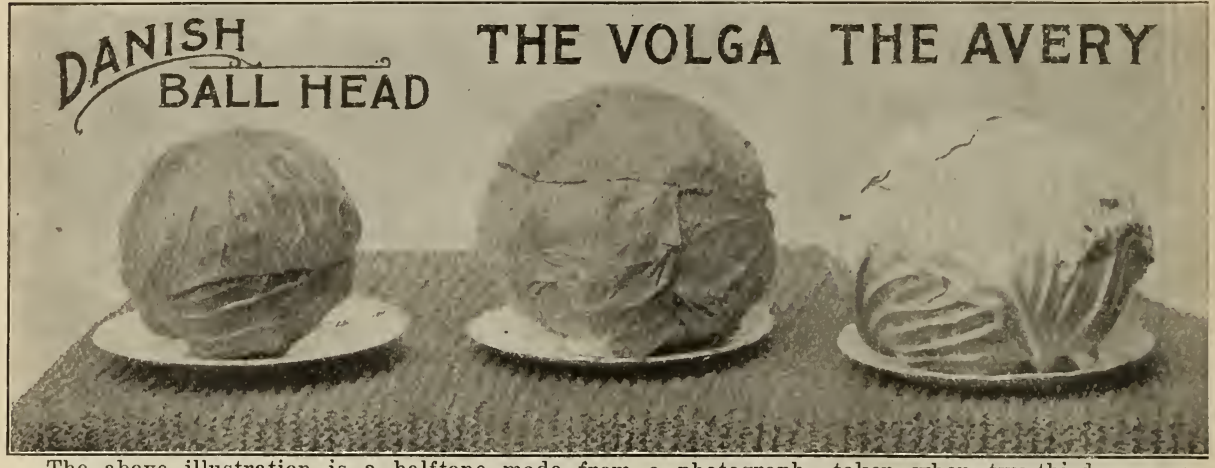

The above illustration is a halftone made from a photograph-taken when two-thirds grown. Note the solidity of the heads and the type of each variety.

THE AVERY CABBAGE.

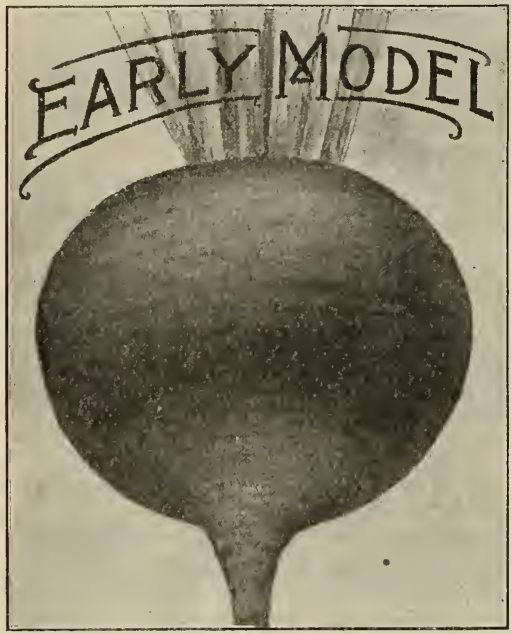

711/2. A grand new Cabbage, entirely free from any disease. The heads are large, about nime inches across, intermediate in form between flat and round (see illustration). The Avery is of the Stone-mason trpe and sure to become very popular. Pkt., 10c; oz., 20c; $1 / 41 \mathrm{~b}$., $70 \mathrm{c} ;$ lb., $\$ 2.50$, postpaid.

\section{THE VOLGA GABBAGE.}

$73 \frac{1}{2}$. $\star A$ very valuable acquisition in the Cabbage line. The heads are as round as a ball (see illustration), and unlike most varieties, are perfectly solid. The flesh is firm, tender and white; most desirable for kraut as well as for all other purposes. It matures fully two weeks earlier than any other of our late growing sorts, and if set out early will mature in July and August. WV predict this cabbage will lead all others as an early-maturing main erop variety. Pkt., 10c; oz., 20c; $1 / 4 \mathrm{lb}$. $60 \mathrm{c}$; 1b., $\$ 2.00$, postpaid.

OLDS' SELEGT DANISH BALLhEAD GABBAGE

82. The best Cabbage for keeping through the winter. The heads, which are perfectly round (see illustration), are very solid and deep, and of a fine white color, making them different in appearance from any other variety. The quality is superior, and it is the best keeper of all cabbages, although not as large as some. Best Imported Danish-grown Seed. Pkt., 5c; oz., $15 \mathrm{c} ; 1 / 4$ lb., $40 \mathrm{c}$; lb., $\$ 1.50$, postpaid.

NEW EARLY MODEL BEET.

44. The Perfect Beet. It is medium early, coming in between the Electric and Crimson Globe (see pages 48 and 49 ). The bulbs run very uniform and are almost round (see illustration); fine-grained, tender and sweet-never woody or stringy. It is a fine variety for the home garden. Pkt., 5c; oz., 10c; 1/4 1b., 20c; 1b., 70c; 5 lbs., \$3.00, postpaid.

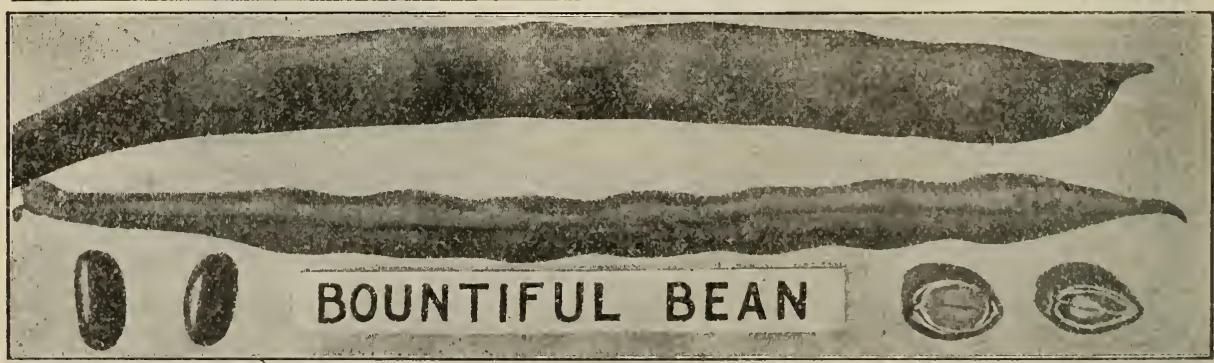

14. BOUNTIFUL. The new Stringless Bush BEAN. Extra early. Tender, large-podded (see illustration), and a bountiful yielder. The flat green pods are absolntely stringless and entirely free from tough, membranous lining. This bean is a continuous bearer-the first in the spring and the last in the fall. Unrivaled for the home garden and just right for the truck patch. Try it. Pkt., 10c; pt., 20c; qt., 35c, postpaid. By express or freight, not prepaid: Qt., 20c; 1/2 pk., 80c; pk., $\$ 1.50$; bu., $\$ 5.00$.

20. THE LONGFELLOW. A new Green Pod BEAN. In extra early variety with perfectly round, straight, flesliy pods-very tender and brittle. We can heartily recommend this variety Pkt., 10c; pt., 20c; qt., 35c, postpaid. By express or freight, not prepaid: Qt., 20c; 1/2 pk., $75 \mathrm{c}$; pk., $\$ 1.25$; bu., $\$ 4.50$

Be sure and deduct $10 \mathrm{c}$ per $\mathrm{lb}$. from mail price, if ordered by express or freight (see page 45 ). 


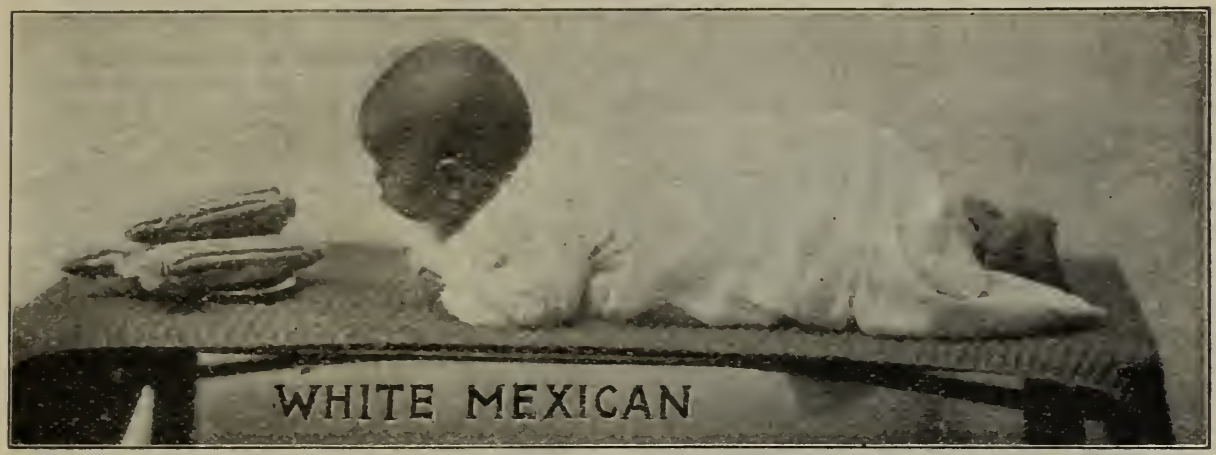

Even the Baby ("Wallace") wants it.

Wes Standard and Other Good Varieties Sweet Corn, pages 52 and 53; Carrots, page 51; Celery, page 55, and Cauliflower, page 56. Order by catalogue numbers. If ordered by express or freialt, deduct 10 cts, per lb.

\section{WHITE MEXICAN SWEET GORN.}

144. The best early market variety. Tlie White Mexican possesses all the good qualities of the old Black Nexican-it is just as sweet and has just as fine a flaror. without the objectionable color. It matures very early, furnishing edible ears (see illustration) from four to six days ahead of the Cory and as early as the Golden Bantam. We claim the White Mexican will lead all the early sorts on account of size of ear, sweetness and fine flaror. Pkt., $10 \mathrm{c}$; pt., $20 \mathrm{c}$; qt., $30 \mathrm{c}$, postpaid. Bv express or freight, not prepaid: Qt., $20 \mathrm{c} ; 1 / 2$ pk., $70 \mathrm{c} ; \mathrm{pk} ., \$ 1.25 ; 1 / 2$ bu., $\$ 2.00$; bu., $\$ 3.75$.

\section{FREE SAMPLES FOR TRIAL} For 1908 Introduction.

We have a new Sweet Corn (very sweet, early and productive), and a new Melon (very attractire and worth testing), which we want our customers to try this vear.

If you order anything from this catalogue amounting to $\$ 1.00$ or more, we will give free, on request, a packet of either the aborestate which one you want.

\section{FARLY SHORT-TOP GARROT.}

$1001 / 2$. $\star T$ best Carrot for family use. In our trial grounds this carrot turned out to be exceptionally fine. It is an attractise stumprooted variety (see illustration). It is a carrot just suited for the family garden and is unequaled; color, rich orange and quality excellent. Pkt., $5 \mathrm{c}$; 0z., $10 \mathrm{c}$; $1 / 4$ lb., $20 \mathrm{c}$; lb., $75 \mathrm{c} ; 5$ lbs., $\$ 3.00$, postpaid.

\section{SNOW WHITE CELERY.}

117. * This Celery is a free blancher and is not subject to rust. It produces heary, crisp stalks and is a good keeper. It matures early and commands high prices when sold in market. The color is pure white, and we predict a great demand for it-give it a trial. Pkt., 5c; oz., 15c; $1 / 4$ lb., 50c, postpaid.

\section{DRY-WEATHER CAULIFLOWER.}

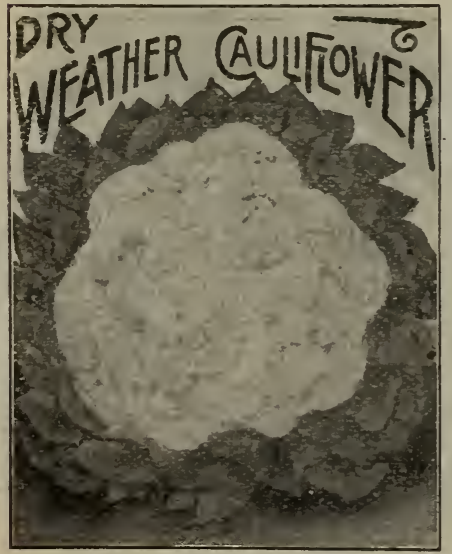

93. The best Cauliflower for every kind of soil-just the rariety for those who would like to grow cauliflower, but who have never been successful with other sorts. It produces large, solid, pure white heads (see illustration). It matures about a week later than our Improred Early Snowball (see page 56), and is especially adapted for growing in dry locations. Pkt., 15 cts.; 2 pkts., 25 cts.; $1 / 4$ oz., 60 cts.; 1/2 oz., $\$ 1.00 ; 0 z$., $\$ 1.50 ; 1 / 4$ lb., $\$ 5.00$, postpaid.

\section{RED BEAUTY POP CORN.}

148. A new red Rice Pop Corn. The ears are medium large; color, bright dark red; grains of good depth, resembling White Rice-cob very small. It is early; ready for popping in four months from planting, and when popped expands into a large, flake-like puff, which is tender and just what the boys and girls are looling for-try it. Pkt., 5 cts.; pt., 20 cts.; qt., 30 cts., postpaid. By express or freight, not prepaid: Pt., 10 cts.; qt., 15 cts.; $10 \mathrm{lbs}$. or more, $6 \mathrm{c}$ per lb.

FREE. Any boy or girl sending us an order amounting to 25 cents or more, can have a packet of this New Pop Corn free. Be sure and ask for it when you order.

Page 56 for other Pop Corns.

"I am well pleased with all the seeds I got of you this spring, and shall give you my whole order next time." Geo. F. Sickinger, Mansfield, Ohio, Nay 9, 1906.

Be sure and get a Packet of our New Muskmelon FREE. See inside back cover. 
Standard and Other Good Varieties Cucumbers, pages 54 and 55; Egg Plant, page 56; Lettuce, page 57; Onions, pages 60 and 61, and Pepper, page 62. Order by catalogue numbers. If ordered by express or freight, deduct 10 cts. per lb.

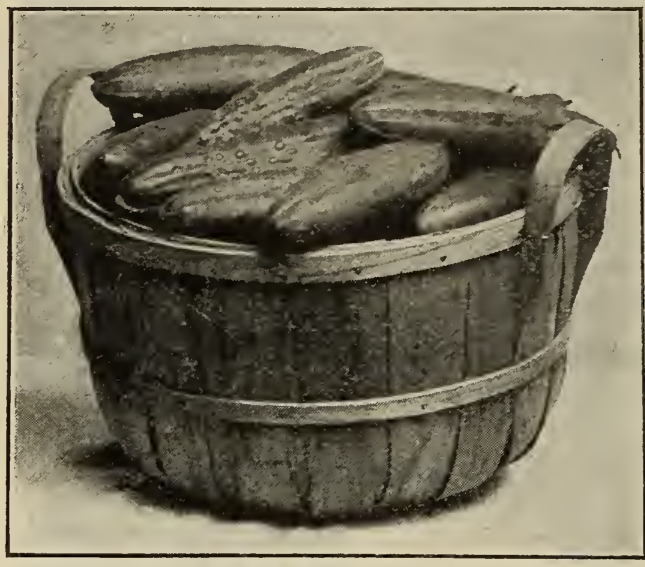

Davis Perfect Cucumber.

\section{DAVIS PERFECT CUCUMBER.}

$1671 / 2$. Unequaled for color, shape and productiveness (see illustration). Mr. Eugene Davis, the originator, and the originator of Grand Rapids Lettuce (page 57) and Davis White Wax Bean (page 47), says: "I have been experimenting for several years and have at last succeeded in fixing a perfect type, combining quality, shape, color and productiveness. The quality is fine, very tender and brittle and with very few seeds; altogether an exceptionally fine table variety." Our seed was grown by the originator. Pkt., 10 cts.; 2 pkts., 15 cts.; oz. 25 ets.; 1/4 lb., 75 cts.; lb., $\$ 2.50$, postpaid.

'OLDS' EARLY WHITE QUEEN ONION. 288. The best of all for small pickles. For some time we have been trying to get an onion that would not grow too large for small pickles. The White Queen grows from one to one and a half inches in diameter, when the tops die down, leaving a neat and handsome white bulb-just the right size for pickling. Pkt., 5 cts.; oz., 15 cts.; 1/4 lb., 50 cts.; lb., $\$ 1.75$, postpaid.

'I was very much pieased with the Dahlia Bulbs you sent me-they are all well rooted.' Jane E. Higday, Evansville, Wis., May 7, 1906. See page 77 .

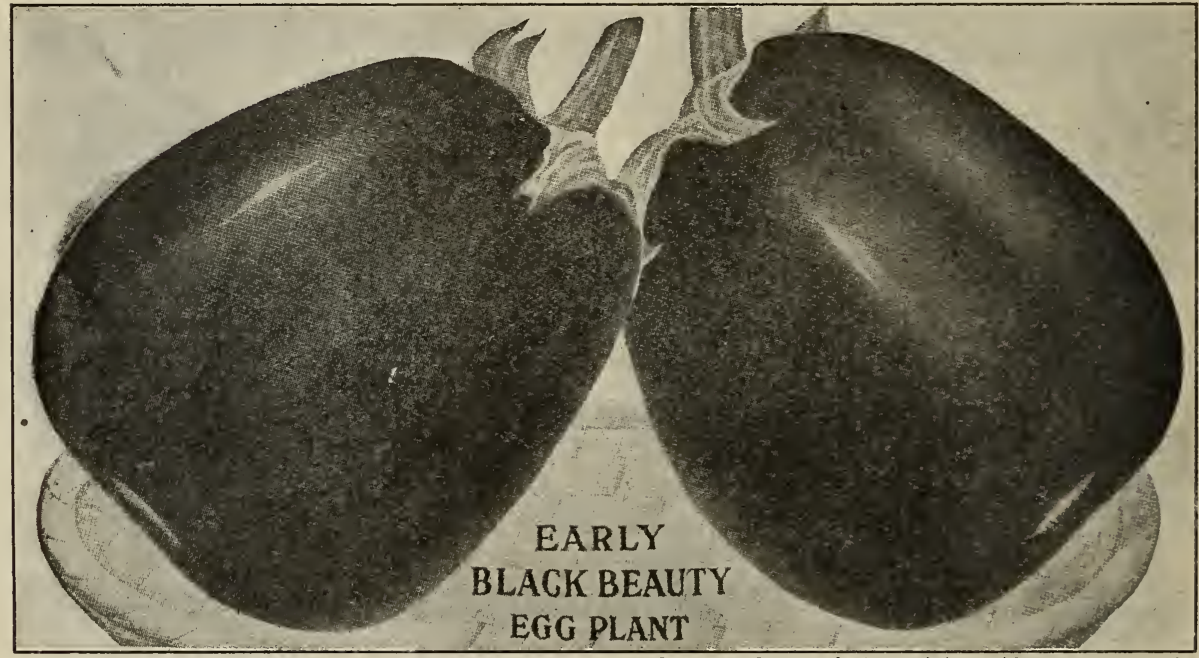

171. \ BLACK BEAUTY EGG PLANT. The best early market variety. Also the best for family use. It is fully ten days earlier than the New York Improved, very attractive in appearance (see illustration), and entirely spineless. The fruits set freely and develop quickly, so that the entire crop can be gathered before frost. We predict this Egg Plant will be in great demand when better known. Pkt., 10 cts.; 2 pkts., 15 cts.; 0z., 30 cts.; 1/4 1b., $\$ 1.00$, postpaid.

\section{MAY KING LETTUCE.}

222. $\star$ The best early-heading variety. The inner leaves are tightly folded (see illustration), of good substance and a rich yellow color - just the lettuce most sought for in market. It is hardy, early and a quick grower. May King is worthy of a prominent position in this catalogue. Pkt., 5 cts.; oz., 15 cts.; 1/4 lb., 50 cts., postpaid. OLDS' EARLY NEAPOLITAN PEPPER.

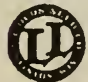
357. $\rightarrow$ The earliest and largest of all red Peppers-see back cover; skin and flesh bright red, thick-meated, sweet and mild. They develop quickly and are ready to use fully two weeks before any other large variety. They carry well and keep in good condition a long time. This Pepper is probably the most productive variety yet introduced, and a dozen plants will supply a large family throughout the whole season. Pkt., 5 cts.; oz., 20 cts.; $1 / 4$ lb., 75 cts., postpaid.

"Have received Chick Feed and think it all right. Enclosed order for Sweet Corn.', C. E.

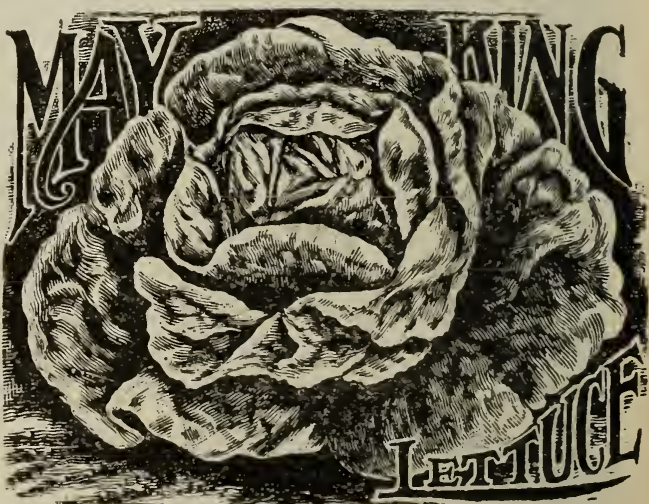
Green, Mendota, Ill., May 8, 1906. See page 85. 
Standard Varieties Muskmelon, page 58; Watermelon, page 59; Peas, pages 63 and 64 ; and Salsify, page 65 . Order by catalogue number. If ordered by express or freight, deduct 10 cts. per lb.

Illustration is a photograph of four sperimens grown on our trial grounds last summernote the perfect shape, great thickness of flesh, small seed carity and most desirable size - The Perfect Melon.

order anything from this catalogue to the amount of $\$ 1.00$ or more, and we will add free, on request, one packet of the EARLY MODEL MELON. We wish to introduce this melon as widely as possible this year - be sure and ask for it when you order. See illustration in colors-outside back corer.

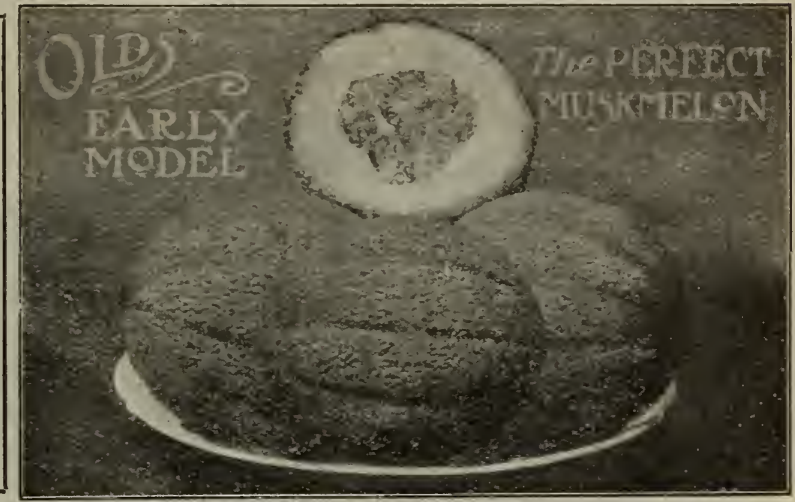

\section{OLDS, EARLY MODEL.}

235. $\star$ The Perfect Muskmelon. For some time we have been trying to get a melon that would mature its whole crop, here in Wisconsin, by the first of September. We cannot expect melons to start growing here much before the first of June, and because our season is so short they have not, heretofore, been grown to any great extent. The Early Model, however, just fills the bill. The vines grow fast and the melons derelop quickly. During a drought

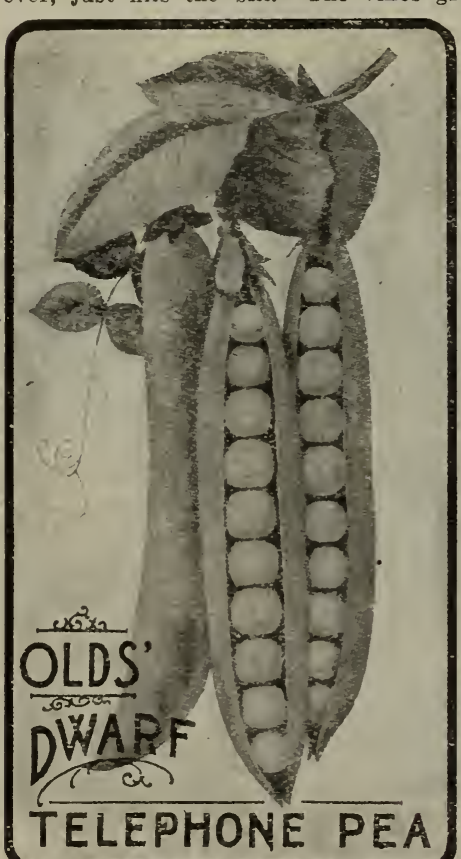
they do not seem to lose their strength and they respond quickly upon the coming of rain. The Nodel averages about two pounds in weight, is perfect in shape (see illustration above, and back cover); the flesh is green and for delicacy and quality of flavor cannot be beaten. The Model has every good quality of the Rocky Ford, with the added ralue of being much more productive and better able to withstand drought. The Model bears transportation well, and on account of its perfect shape and size will bring fancy prices on any market. The Model is just the melon also for the home garden, and if you once plant it you will want no other.

PRICES FOR 1907: Pkt., $10 \mathrm{cts.;} \mathrm{0z.,} 20 \mathrm{cts}$; 1/4 lb., 50 cts.; lb., \$1.25, postpaid.

FREE SAMPLES FOR TRIAL

For 1908 Introduction.

We have a new Sweet Corn (very sweet, early and productive) and a new Melon (very attractive and worth testing), which we want our customers to try this year.

If you order anything from this catalogue amounting to $\$ 1.00$ or more, we will give free, on request, a packet of either of the above-state which one you want.

\section{OLDS" DWARF TELEPHONE PEA.}

338. The most prolific Dwarf Pea; producing large, C. 0 handsome pods like the Telephone (see illustration opposite, also on back cover), but without the tall we!l filled with pale green peas of the best quality - just the pea for the home garden. Try it. Pkt., 10 cts.; 2 pkts., 15 cts.; pt., 25 cts.; qt., 45 cts., postpaid. By express or freight, not prepaid: ${ }^{\text {Qt., } 30}$ cts.; p p., $\$ 2.00 ;$ bu., $\$ 7.50$. "Find enclosed $\$ 4.00$, for enclosed order. Mr. Anton Goetz, one of your old customers, gave me your address and catalogue." "Aug. Engstrom, Wesley, Iowa, May 5, 1906.
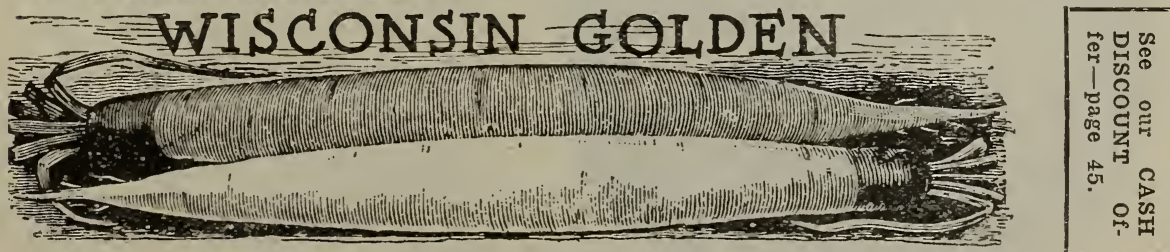

396. WISCONSIN GOLDEN SALSIFY. Originated here in Southern Wisconsin. In habit of growth it is like the old oyster plant (see illustration), excepting the roots have a slight yellow tinge. When prepared for the table, it is very tender, rich and delicious. Pkt., 5 cts.; 0 z., 10 cts.; $1 / 4$ lb., 30 cts.; 1b., $\$ 1.00$, postpaid.

NOTE inside back cover for WHAT WE DO for the benefit of our Customers-By benefiting them we help ourselves. 
Standard Varieties Tomatoes, page 67; Our Model Collection (illustrated in colors), back cover; Early Bird and other Collections, pages 69 and 70 . Order by catalogue numbers. If ordered by express or freight, deduct 10 cts. per $\mathrm{lb}$. One pound of any variety at 3 times cost of $1 / 4$ lb. If larger quantities are wanted, write for special prices.
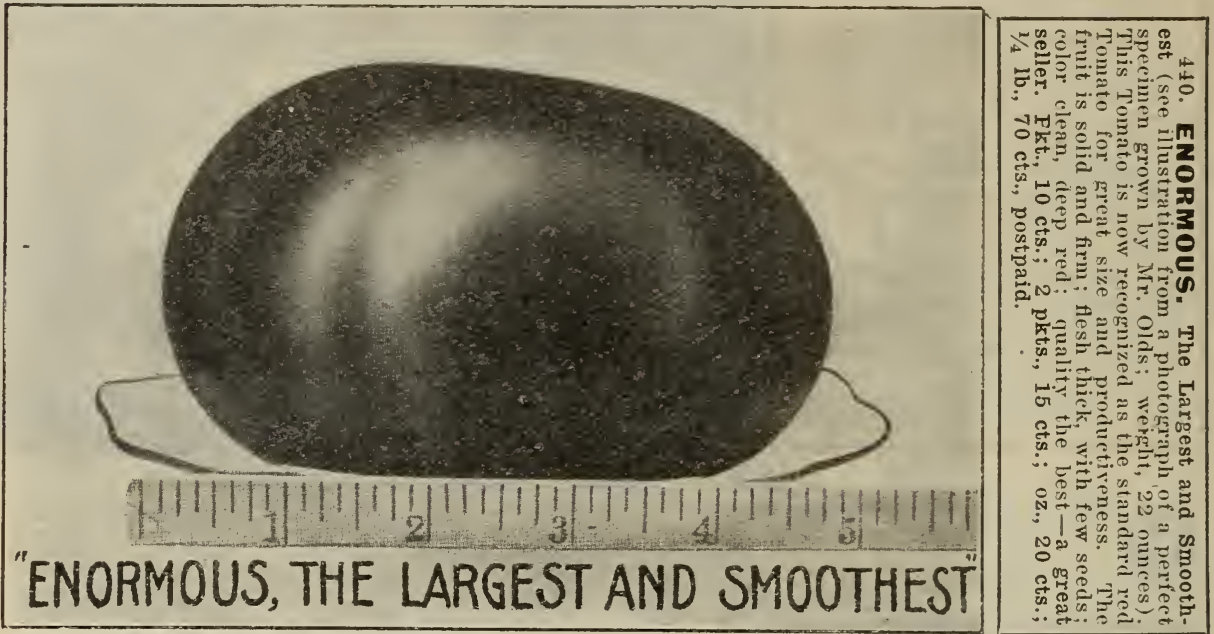

NEW GLOBE TOMATO.

441. $\star$ Livingston's 1905 introduction. This Tomato is a beautiful globe in shape, resembling a peach in form (see illustration). On account of its shape, a greater number of slices can be taken from each one. It ripens with the first earlies. The fruits are large, smooth, firm and with few seeds. It ripens evenly, with a fine, glossy rose, tinged with purple. It is very productive and a good keeper. The seed of this Tomato could orly be procured the first year from the introducers, and in sealed packets. This year we have enough seed to take care of all early orders at the fol lowing prices: Pkt., 10 cts.; 2 pkts., 15 cts.; oz., 20 cts.; $1 / 4$ lb., 75 cts., postpaid.

\section{SUCCESS.}

426. A new Tomato well worthy of the name "Success." It is just right for a second early; bright scarlet, of fine flavor and handsome in appearance. The vines are strong and vigorous; fruits set in clusters and average three inches in diameter-perfectly smooth and free from cracks. Ripens. with the second-earlies and yields abundantly. The handsome appearance, even size and great solidity of "Success', make it an excellent market variety, while its deep color and solidity make it also well adapted for canning. Pkt., 10 cts.; 2 pkts., 15 cts.; oz., 20 cts.; 1/4 lb., 65 cts., postpaid.

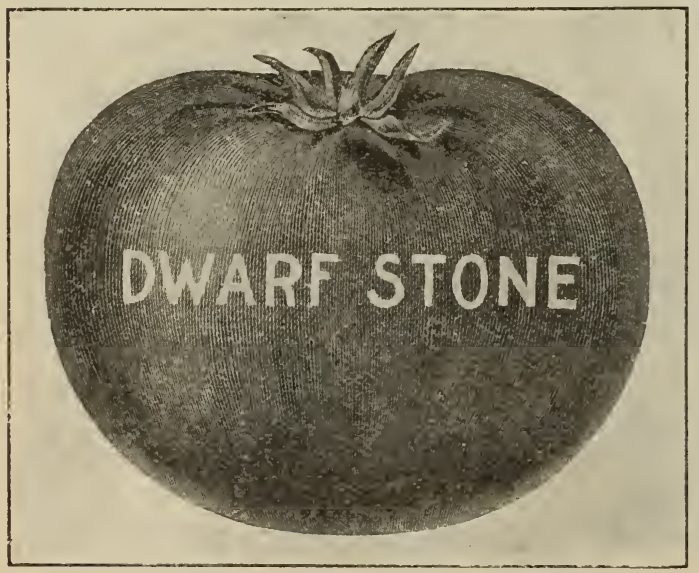

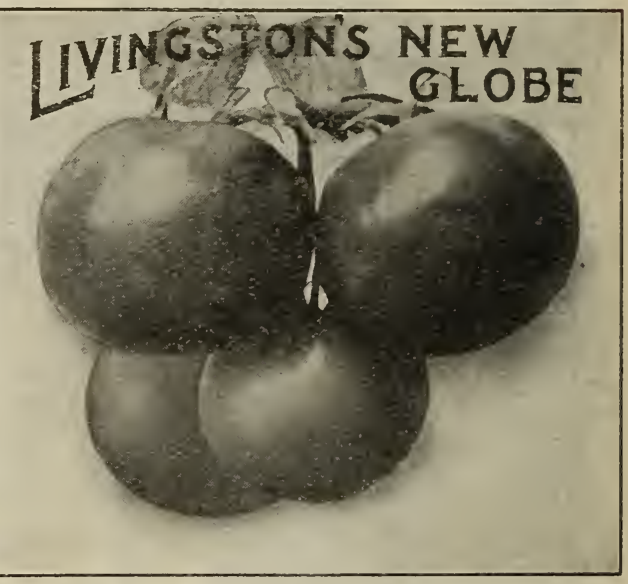

NEW DWARF STONE.

429. Another of Livingston's recent introductions. Almost every one is ac: quainted with the Stone Tomato. In the Dwarf Stone we have a tomato with s.trong, compact, upright rines, keeping the fruit well up from the ground and enabling closer planting, which is an ad. vantage in a small garden and with growers having only a limited acreage. The tomatoes are perfect in shape (see illus tration), have a good skin, are solid in flesh and ripen evenly. Bright red in color and fast becoming a general fa rorite. Pkt., 10 cts.; 2 pkts., 15 cts.; oz., 20 cts.; 1/4 lb., 60 cts., postpaid.

Those marked with a $(\star)$ are the varieties we specially recommend for general cultivation - see next page for a list of the best of the new varie'ies. $2 \times$ We believe we are the only recdsmen who allow a straight Cash Discount-see page 45 .

एas -each package contains, and also general culture directions with each and every packé. 
T5 Standard Varieties of Radish, page 65; Turnip, page 68; Collections, pages 69 and 70 ; Varieties we specially recommend, first, under each respective heading, pages 45 to 68 . Order by catalogue numbers. If ordered by express or freight, deduct 10 ("ts. per th. If larger quantities are wanted, write us for special prices.

\section{Crimson Giant radish.}

374 $\star$ A new, distinct Forcing Radish, suitable for the open ground. This Radish grows much larger than other extra early varieties (see illustration), and has a beautiful crimson color. The flesh is firm, crisp and tender. We reeommend it for first outdoor planting. Pkt., 5 cts.; 02, $10 \mathrm{cts}$.; 1/4 lb., 15 cts.; lb., 50 cts., postpaid.

\section{FIRST AND BEST RAUISH.}

3h1/2. A medium-sized early radish, with a small top. The color is a ricli, deep scarlet; uniform roots, tapering to a point. The quality is fine; crisp and juicy. This is probably the best early, half-long radish, and we would recommend it for the home garden. Pkt., 5 cts.; oz., 10 cts.; $1 / 4$ lb., 20 cts.; lb., 60 cts., postpaid.

\section{WHITE DELICIOUS RADISH.}

$3731 / 2$. The best white summer radish. This radish is handsome in appearance; crisp and mild in flavor and will remain a long time in good condition. The roots are pure white, half-long in form, gradually tapering at the lower end. For outdoor and early fall sowing it is sure to make a good crop, and it is an ideal market gardener's sort. Pkt., 5 cts.; oz.. 10 cts.: 1/4 lb., 20 cts.; 1b., 75c, postpaid.

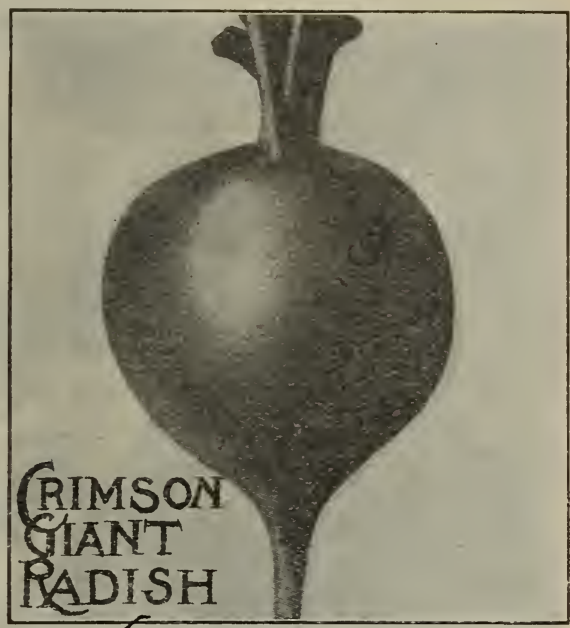

SNOWBALL TURNIP.

4601 The most suitable white turnip for

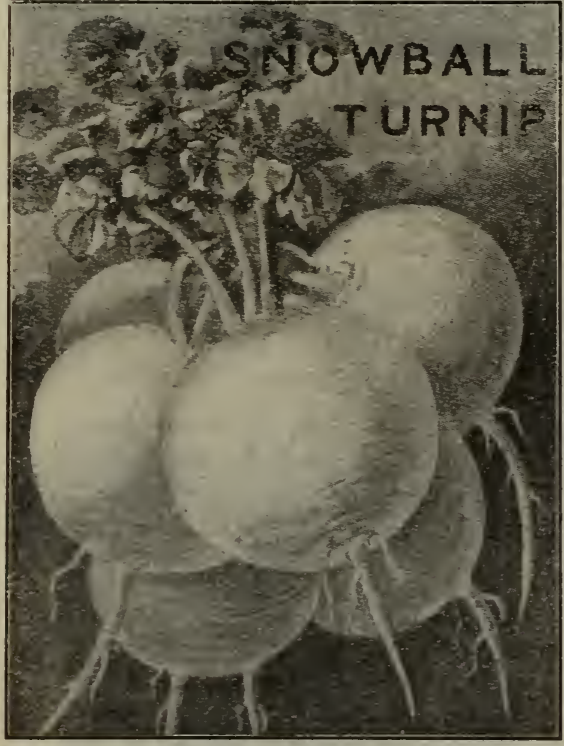

table use. This turnip is very handsome in appearance (see illustration); skin and flesh pure white; flesh crisp, tender and very sweet-very desirable for sowing early. It matures in six weeks and is a good keeper. Pkt., 5 cts.; 0z., 10 cts.; 1/4lb., 15 cts.; lb., 50 cts postpaid.

\section{GOLDEN BALL TURNIP.} use. This turnip is globe-shaped, matures early and is a good keeper. It is rich, fine flavored and the best yellow turnip yet introduced. Pkt., 5 cts.; oz., $10 \mathrm{cts}$; 1/4 lb., 15 cts.; lb., 45 cts., postpaid.

WE PAY THE POSTAGE. Do not lose sight of this fact when comparing our prices with those of other reliable seedsmen. If ordered by express or freight, deduct 10 cts. per lb. If more than $\$ 10.00$ worth of Garden Seeds are wanted, write us and we will quote special prices - see Discounts, page 45.

UNSOLICITED TESTIMONIALS.

Like most other seedsmen, we receive, every year, a large number of testimonial letters from our customers. These letters are unsolicited; perhaps we have one from your neighborhood we will gladly send them on request and be pleased to have any of them used as references.

NOTE. - We believe in illustrations from photographs. If you raise anything nice from our seeds, send us a photograph of it-see page 59 .
THE BEST OF THE PRECEDING NEW VARIETIES. One Packet of each, 50 cents. Any 5 pkts., 25 cents.

731/2. THE VOLGA CABBAGE. An early-maturing main crop variety.

See page 12 1001/2. EARLY SHORT TOP CARROT. A family garden variety. See p. 13 117. SNOW WHITE CELERY. A free blancher. See page 13.

$1671 / 2$. DAVIS PERFECT CUCUMBER. A very fine table variety. Seed grown by the originator. See page 14

171. BLACK BEAUTY EGG PLANT. The best early variety; very attractive and productive. See page 14.

222. MAY KING LETTUCE. See page 14

235. OLDS' EARLY MODEL. The Perfect Muskmelon. See page 15..

357. OLDS' EARIY NEAPOLITAN. The earliest and largest of all red Peppers. See page 14

374. CRIMSON GIANT RADISH. See page 17.

441. LIVINGSTON'S NEW GLOBE TOMATO. A beautiful, early sort: lar. and smooth, with but few seeds. See page 16

4601/2. SNOWBALI TURNIP. For table use. See page 17.

\begin{tabular}{|r|r|r|r}
\multicolumn{4}{|c}{ By Mail, postpaid. } \\
\hline pkt. & \multicolumn{1}{|c}{ oz. } & $1 / 4 \mathrm{lb}$. & \multicolumn{1}{c}{ lb. } \\
\hline 0.10 & $\$ 0.20$ & $\$ 0.60$ & $\$ 2.00$ \\
.05 & .10 & .20 & .75 \\
.05 & .15 & .50 & \\
.10 & .25 & .75 & 2.50 \\
.10 & .30 & 1.00 & \\
.05 & .15 & .20 & \\
.10 & .20 & .50 & 1.25 \\
.05 & .20 & .75 & \\
.05 & .10 & .15 & .50 \\
.10 & .20 & .75 & \\
.05 & .10 & .15 & .50 \\
\hline
\end{tabular}

Any 3 ten-cent Packets of Peas, Beans or Sweet Corn for 25 cents. 
This page contains a selection of the new varieties of flower seeds tried by us last summer on our trial grounds. They are all of recent introduction and improvements on older sorts. TVe know our customers will be well pleased in giving them a trial. By mail, postpaid. Order by number. Regular list of Flower Seeds, pages 71 to 76 ; Bulbs, page 77, and Plants, pages 78 and 79 .

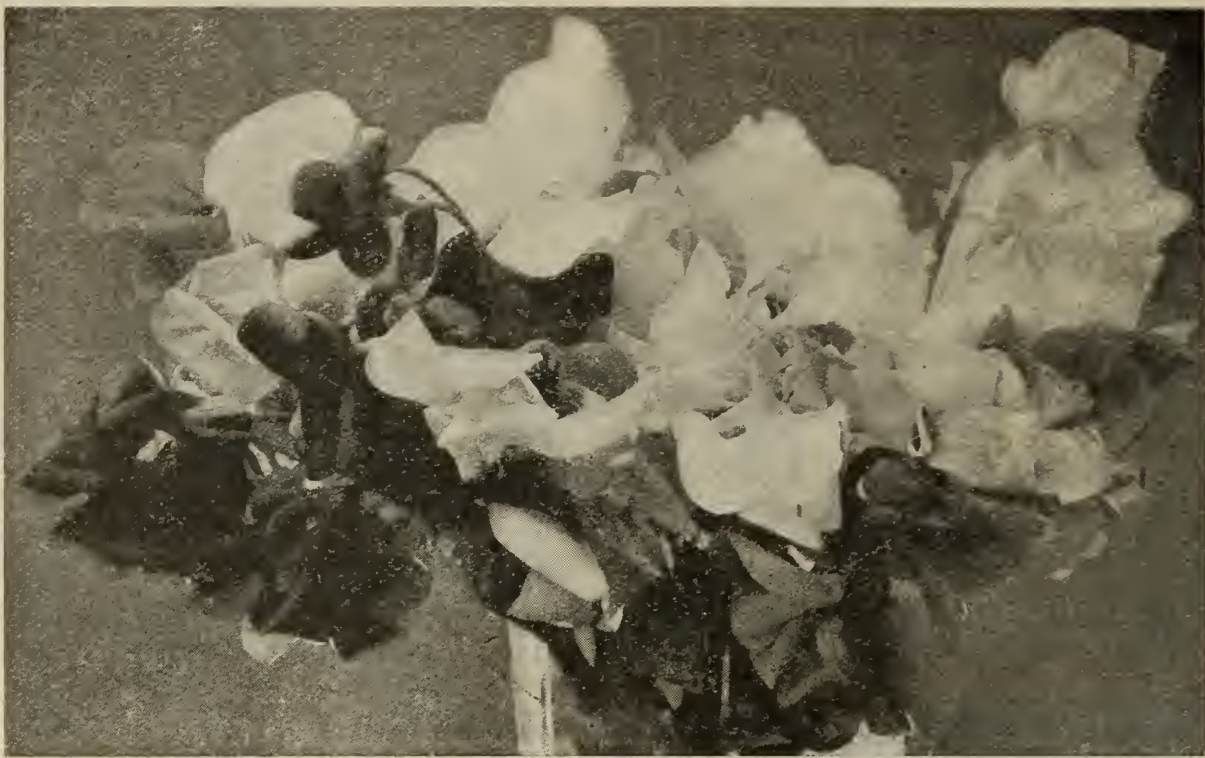

NEW SWEET PEAS. 1 Packet of each, 50 cts.; any 6 5 Packets, 25 cts.

1108. Dorothy Eckford The best white $11201 /$ Janet Scott Bright pink: curled Sweet Pea in existence today. Pkt., 5c; oz., 10c. petals; very attractive in appearance. Plit. $11101 / 2$. Dainty. Pure white, edged with pink; long stems, with four blossoms. Pkt., 5e; oz., 10c.

$1111 \frac{1 / 2}{2}$ Evelyn Byatt. The richest colored sweet pea ever introduced-striking orange color. Pkt., 10 ets.; 2 pkts., 15 ets.; oz., 25 cts.

$1112 \frac{1 / 2}{2}$ Golden Rose. Primrose, very large.

Wings with wavy edges. Pkt., 5c; oz., $10 \mathrm{c}$.

$1116^{1 / 2}$. Helen Pierce. Bright blue, bellshaped flowers, not striped, but mottled like Gloxinias; gives a fine effect when bunched. Pkt., 15 cts.; 2 pkts., 25 cts.

This assortment of sweet peas makes the mosi handsome bouquet we have ever gathered-see illustration above.

TWO NEW ASTERS.

813. VIOLET KING. A new, distinct variety, with long, strong stems; double flowers of good size, with the pleasing, soft shade of violet. Pkt. 15 ets.; 2 pkts., 25 cts

814. WHITE HERCULES. A new variety of great merit; strong stems 15 to 20 inches high pure white flowers 6 to 7 inches in diameter (see illustration-flower seed heading-page 71). Pkt. 10 ets.; 2 pkts., 15 cts.

934. DIANTHUS SNOWDRIFT. One of the most beautiful pinks ever introduced. The plant grows one foot high, is robust and produces large, pure white flowers; very effective and equal to carnaltions. The Snowdrift also makes a fine houseplantwill bloom freely all winter. Pkt., $10 \mathrm{c} ; 2$ pkts., $15 \mathrm{c}$

TWO NEW PANSIES.

MASTERPIECE. A grand new pansyone of the most distinct sorts ever developed; very laroe, rich and beautifully colored. The petals are frilled and ruffed, giving the flower a unique double appearance. Pkt., 10 ets.: 2 pkts., 15 cts.

$1038 \%$ HERCULES GIANT. We believe this to be the largest and finest pansy yet introduced. It certainly was the wonder and adiniration of every one who saw it in our trial grounds last summer; petals very large and rich in coloring and markings -an abundant bloomer and with no small flowers.

\section{BURBANK'S FAMOUS NEW POPPY.}

$1053 \frac{1}{2}$. SANTA ROSA. Few flowers can excel the poppy in freedom of growth, beauty and loveliness, and none excels the Santa Rosa in beauty of color, texture and originality of type-it will have to be seen in order to be fully appreciated. Pkt. 10 ets.; 2 plkts., 15 its. 5 cts.; oz., 10 cts.

$1121 \frac{1}{2}$. Gladys Unwin. A gorgeous new pink sweet pea; large flowers, with long stems and usually four blossoms to a stem. Pkt., 10 cts. 2 pkts., 15 cts.; oz., 25 cts.

1129. Countess Spencer. Bright, clear pink large blossoms on long stems. Pkt., 5c; oz, 15c. 1134. King Edward VII. Bright red; very large and open. Almost a solid color and the best red sweet pea. Pkt., 5 cts.; oz., 10 cts.

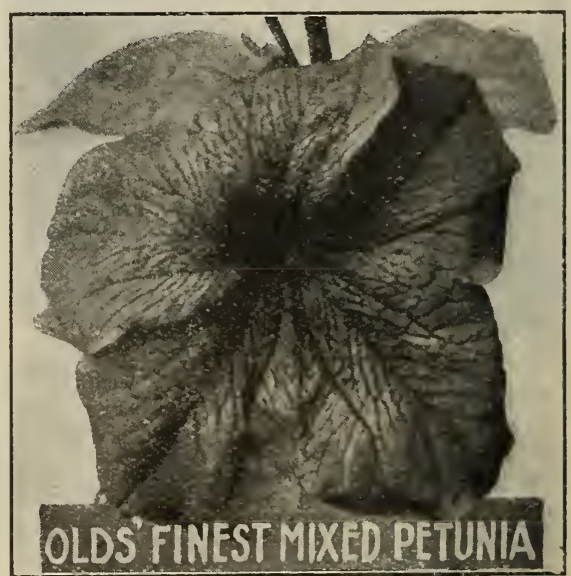

1044 OLDS' FINEST MIXED FETU

NIA. Everybody loves petunias - they are such free bloomers, but many are often dis appointed in finding the flowers so small Olds' Finest Mixed produces the largest flowers - see iliustration (from a plotograph). Plit., 15 cts. ; 2 phts., 25 cts. Other Varieties Sweet Peas, Pansies, Asters, etc., poges 71 to 76. 


\section{STANDARD VARIETIES POTATOES.}

(For Newer Varieties of Potatoes, see pages 9, 10 and 11.)

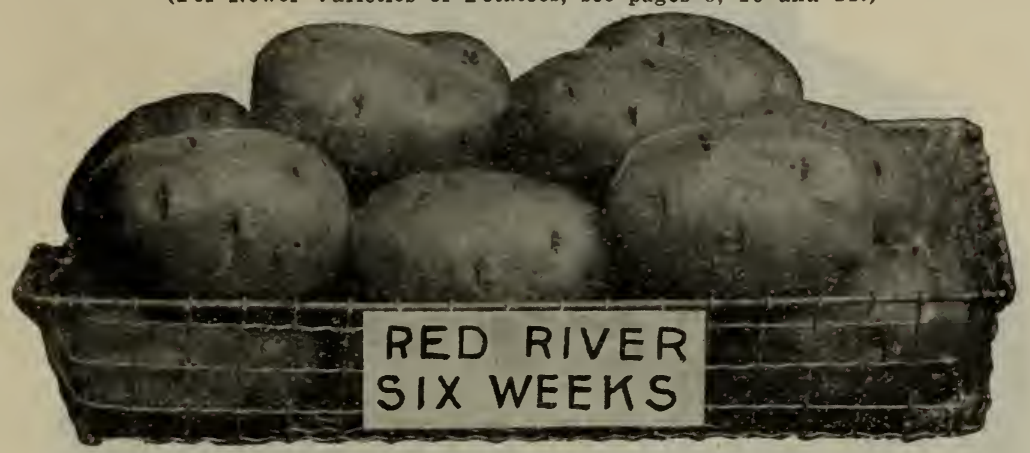

EARLY SIX WEEKS.

HARDLY MATURES IN SIX WEEKS, BUT VERY EARLY.

We are not going to be careless enough to say that this potato gets ripe in six weeks from planting, or foolish enough to think that our customers would believe such a statement. That is just what some seedsmen do claim, however, and even go so far as to picture out the appearance of the field at the end of each week. We prefer to simply say that it is an extra early, a little earlier even that Early Ohio. It has become immensely popular, and is much sought after, especially by market gardeners. Although first introduced some 17 years ago, the seed is always in demand and-sells at a premium over other earlies. Six Weeks belongs to the Ohio family, resembles Early Ohio, but is usually a little rerlder in color. It makes an extremely quick growth, grows very compactly and yields well. Our stock this year of Red River Six Weeks is very, very fine. They will please every one.

Red River Six Weeks: Pk., 50c; bu., \$1.50; bbl., \$3.25; 5 bbls. at \$3.10; 10 bbls. at $\$ 3.00$.

Home-grown Six.Weeks, from Red River Seed: Pk.,.50c; bu., \$1.40; bbl., $\$ 3.00 ; 5$ bbls. at $\$ 2.85$.

(Our potatoes are all sold by weight; a bushel is 60 pounds, and a barrel $2 \frac{3}{4}$ bushels, or 165 pounds net.)

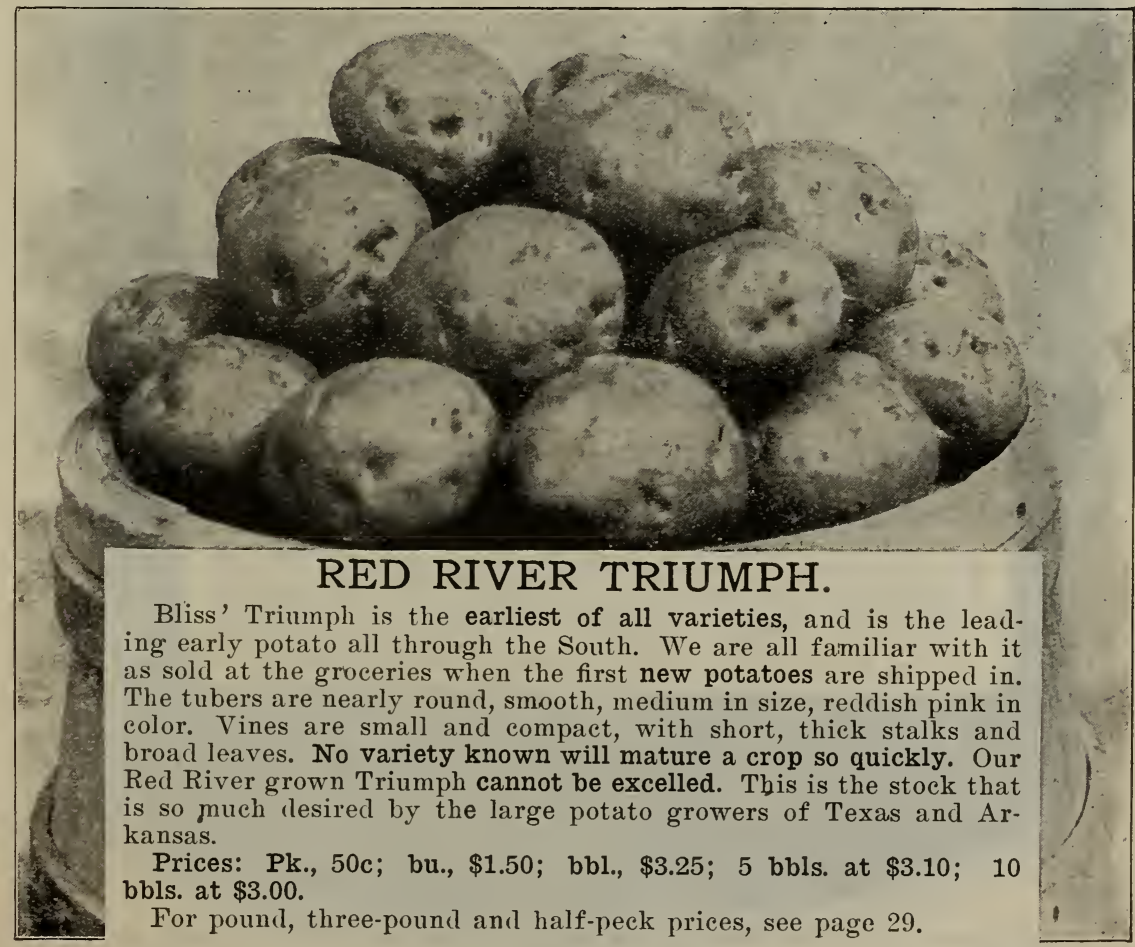




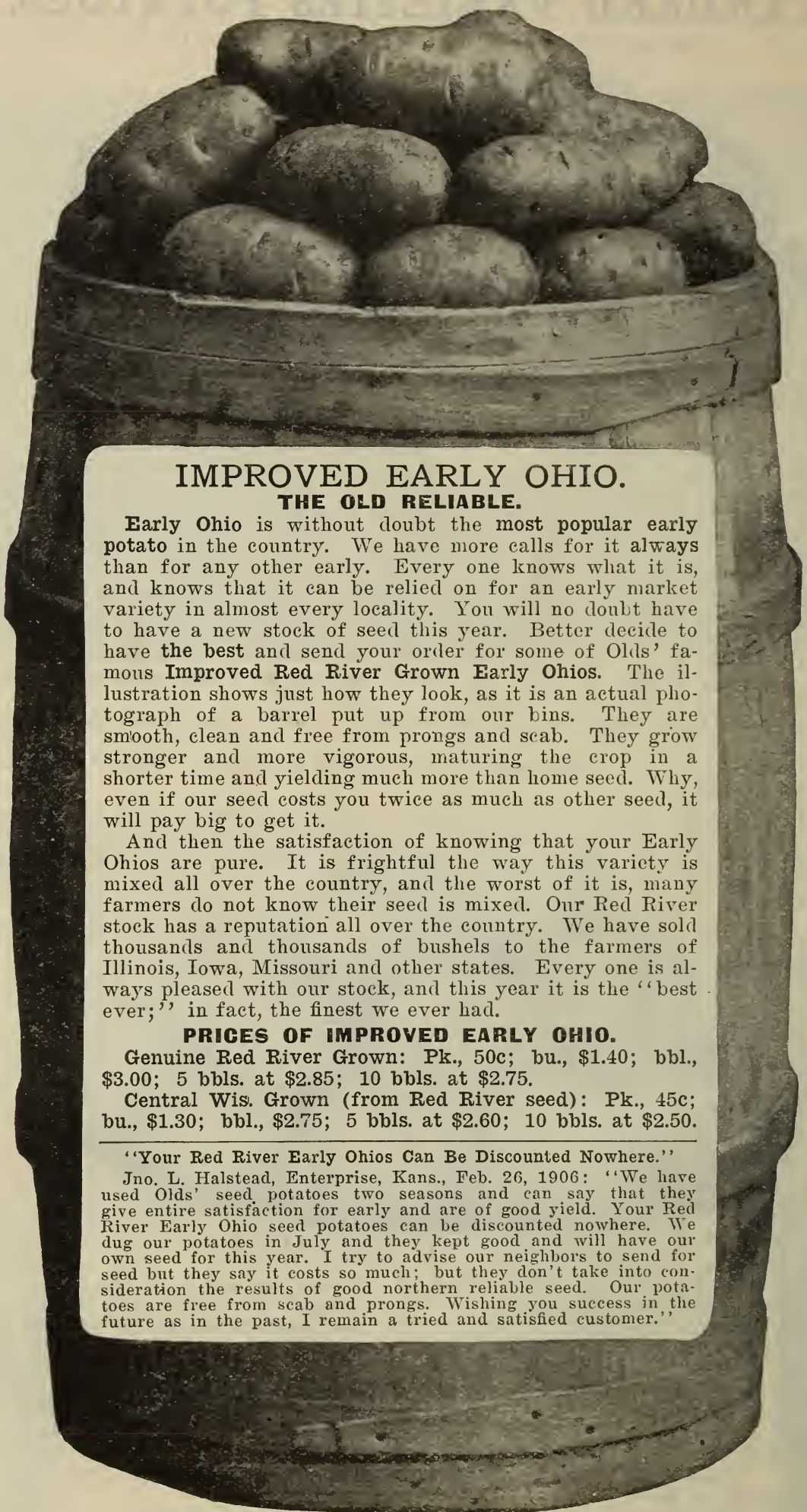

For pound, three-pound and half-peck prices, and for second size, see page 29. 


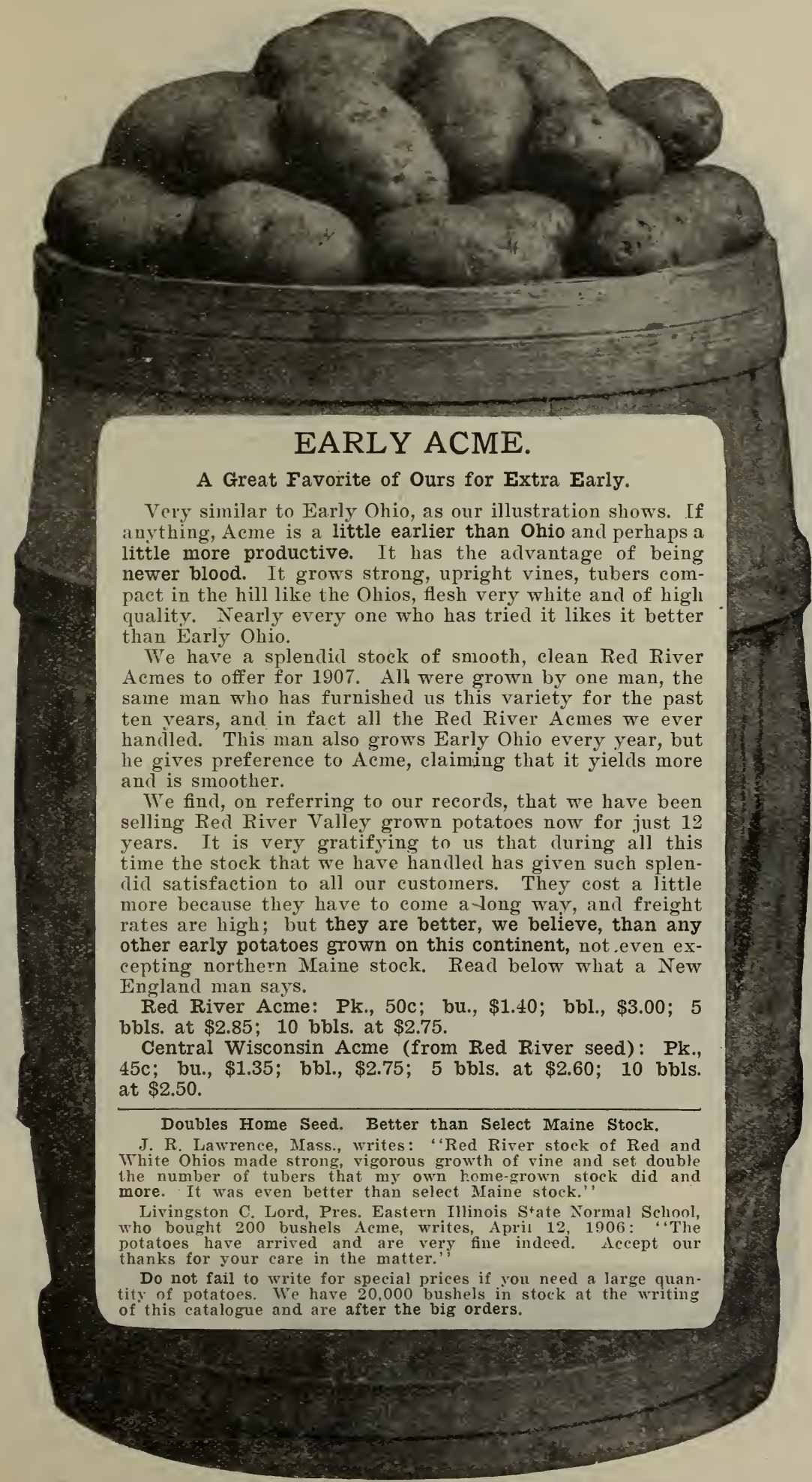

We pack all early shipments in lined barrels without extra charge. 


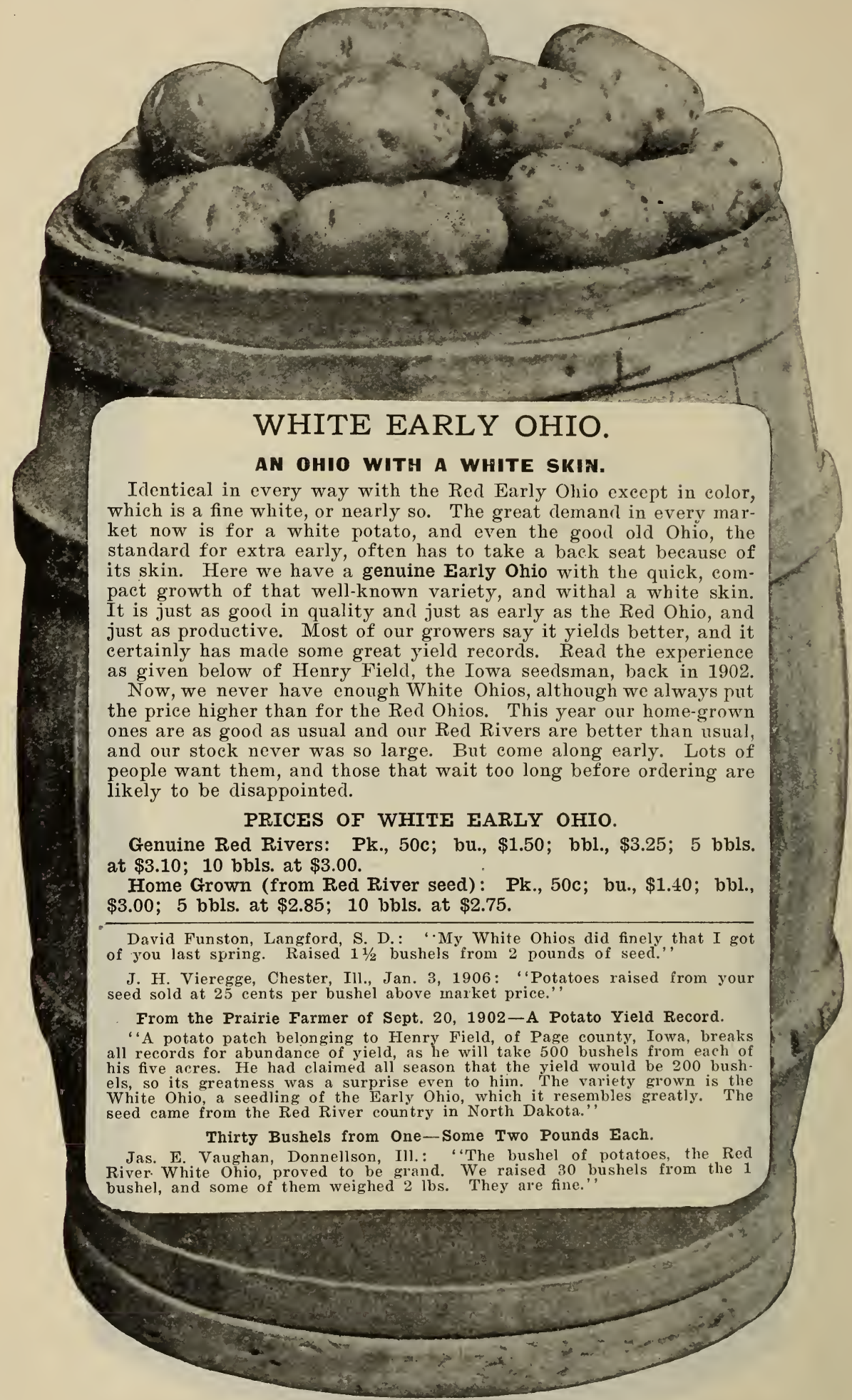

See page 29 for prices in smaller quantity than above. 


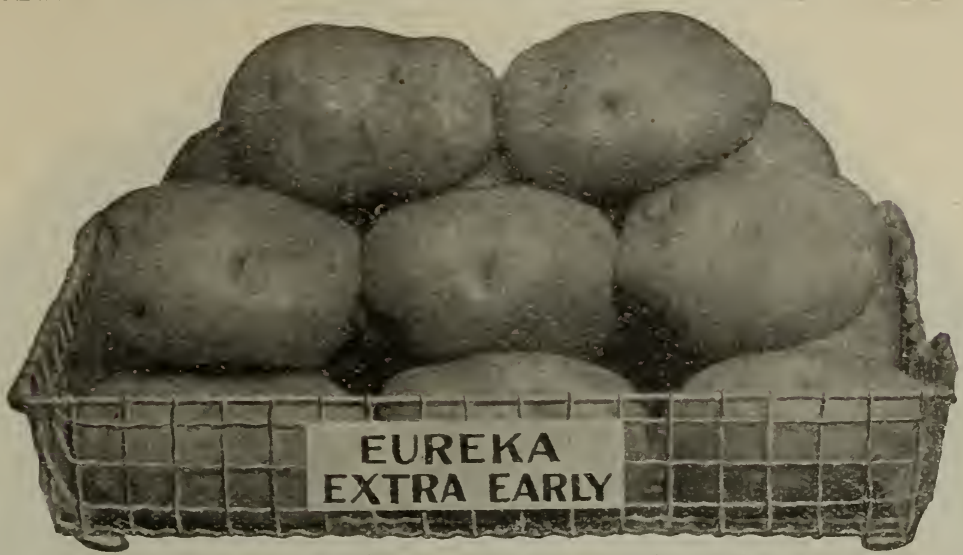

\section{EUREKA EXTRA EARLY.}

A famous extra early, introduced in 1902 by two eastern seedsmen, Burpee and Naule. It is of handsome appearance, tubers nearly round, pure white in color, with smooth skin and few eyes. Our photograph above well represents it. We have found it nearly as early as Bliss' Triumph, the standard for extra early, but it grows a larger and stronger vine and yields much better, and for appearance it has Triumph beat a mile. J. J. Wilson of Northern New York tells in the December (1906) Garden Magazine how he grew Eurekas in 7 weeks from date of planting. He says: "These are the earliest potatoes ever raised in this part of the state." Eureka has a very pretty light pink blossom, but there is no pink shade at all about the eyes of the potato, and the skin is a pure, transparent white all over. The quality is good, specially so for an extra early, and here in our section it seems to outyield all of the Ohio type varieties, although not quite as smooth. Try it for an extra early white. Stock somewhat limited.

Prices: Pk., 50c; bu., $\$ 1.60$; bbl., $\$ 3.50 ; 5$ bbls. at $\$ 3.35$.

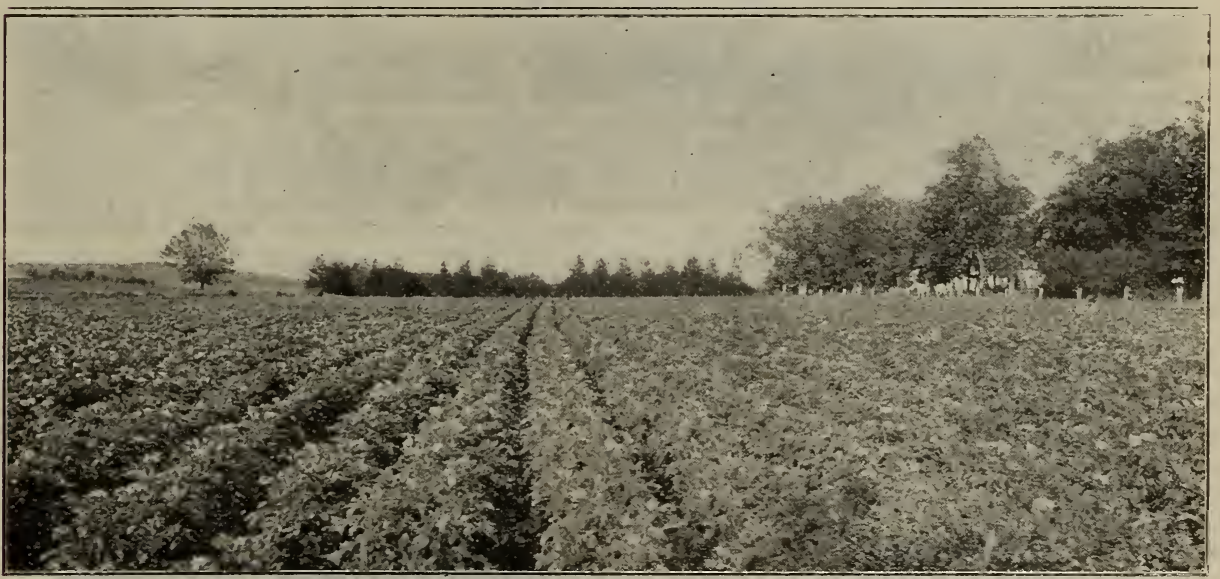

Field of Pingree as grown on the Olds Farm near Clinton, photographed July 1, 1899.

\section{PINGREE.}

This potato is one of our own introductions, and was first catalogued by us in 1899. We have been practically out of it for the last two years, but this year were able to get hold of a splendid stock of nice, clean, smooth Pingrees grown from our seed by one of our customers in the potato regions of Central Wiscon-

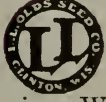
of potato that many are looking for-a smooth, rather long, white-skinned extra early of the Puritan type. We only wish we had more of them. The original description of the potato, to quote from our 1899 catalogue, is as follows:

"Most desirable of shape, neither too long nor too round, very smootli and regular in form, eyes shallow, and a white skin with an unusually thick netting for so early a potato. Top, medium in size but strong and spreading, tubers unusually close together in the hili, numerous, but attaining an edible size in remarkably quick time. Quality first-class, cooking up dry, white and mealy, even before fully ripe. A grand yielder and an extra early."

Prices: Pk., 50c; bu., $\$ 1.40 ;$ bbl., $\$ 3.00 ; 5$ bbls. at $\$ 2.85$. 


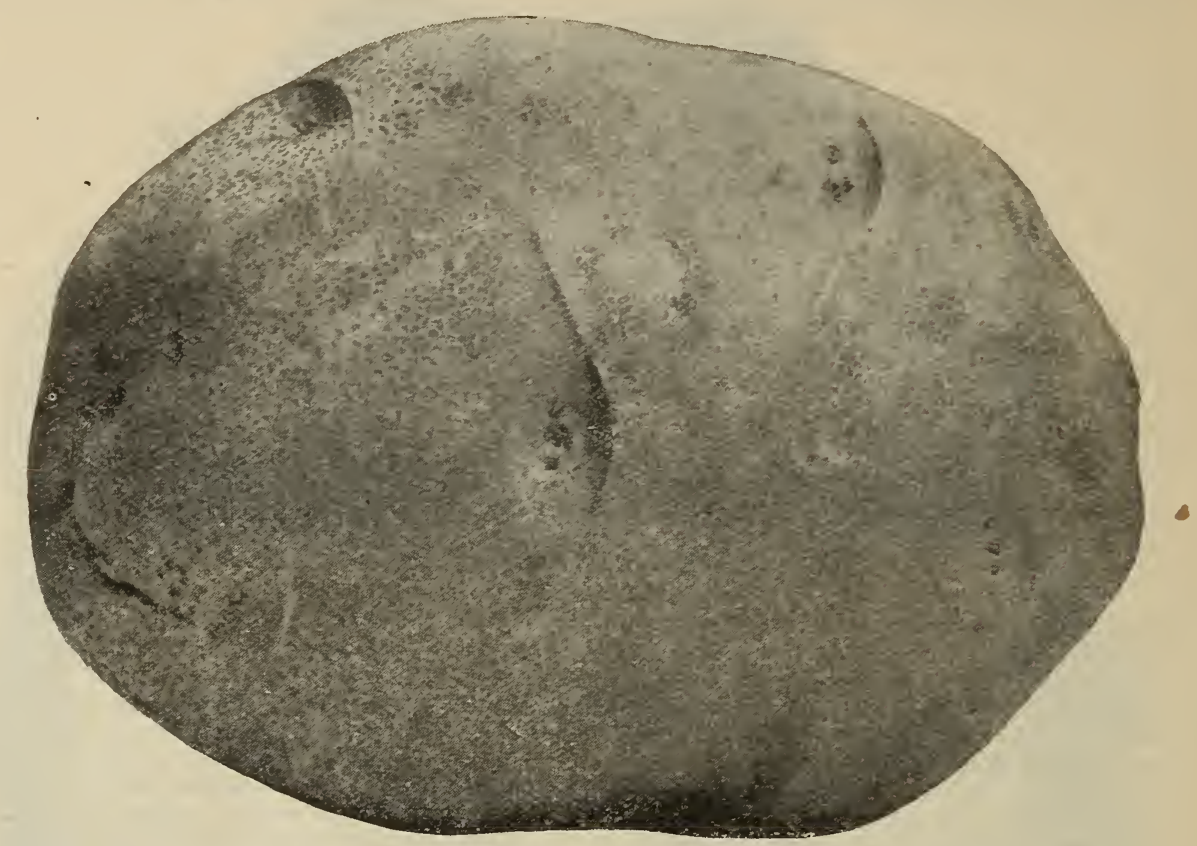

\section{SIR WALTER RALEIGH, King of the Rural Varieties. MOST PROFITABLE ALL-ROUND MAIN.GROP POTATO.}

It is generally spoken of as "Mr. Carman's Best,"' and that is what we call it. With our growers it has made the very best continuous record of all our varieties for yield, size, smoothness and handsome appearance. Good large size, hardly ever any small ones, nearly round in shape, but flattened, just what is most desired now; skin pure white, thin and transparent, eyes few and very shallow; potatoes never prongy and never seabby, almost blight-proof, a sure yielder where others fail, in clay soil and all other soils. Sir Walter Raleigh was first introduced in 1897. We have had it from the first, and it is now just in its prime. We cannot see that it has begun to deteriorate at all. On the other hand, we think we have improved it. The stock we offer is not only smooth and of most desirable shape, but is free from extra large, overgrown tubers which no one wants for planting. The illustration above shows a photograph of a specimen that is plenty large enough. We seldom have them any larger, and we would not want them larger. If they were, they would not make desirable seed.

Now, any farmer who wants pure, vigorous seed of the best all-round market variety had better order some of Olds' Sir Walter Raleighs. The farmers around here pretty near all plant them for main crop in preference to anything else. Probably threefourths of all the late potatoes grown in this region now are Sir Walter Raleighs. How is that for a recommendation?

Prices: Pk., 40c; bu., \$1.25; bbl., \$2.50; 5 bbls. at $\$ 2.35 ; 10$ bbls. at $\$ 2.25$.

\section{VORNEHM}

\section{(Pronounced Forename.)}

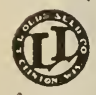
Introduced by us in 1904. Essentially a high quality potato. We do not recom. mend it for the average farmer or for the large commercial grower, but on rich land with high resembles the old Snowflake. It has the same creamy-white skin and thick netting, with the peculiar rich, nutty flavor belonging to that variety. It has very shallow eyes and is of most desirable shape. Cooks white and floury, and for quality stands at the top of the list. Just the thing for any one who wants to grow something specially nice in the garden for his own use. Medium in season. Stock, very limited this year.

Prices: Peck, 50 cts.; bu., \$1.50; bbl., \$3.25.

(See page 29 for "Second Size," "Collection Offers," etc.)

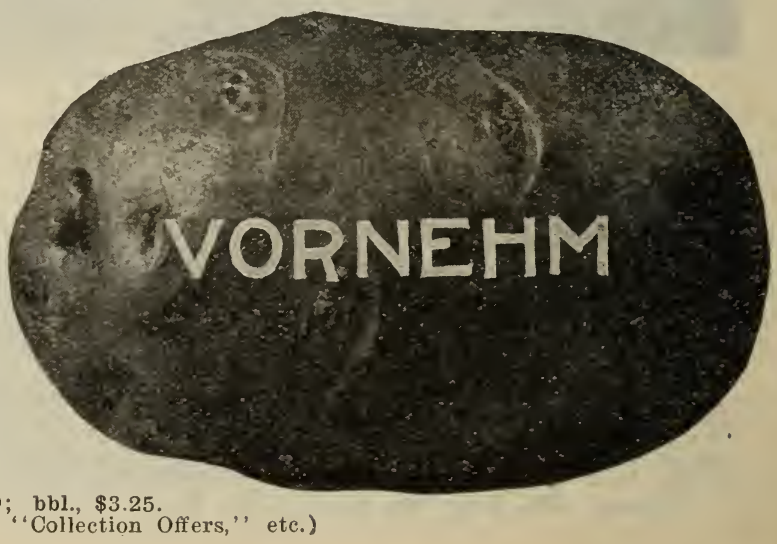




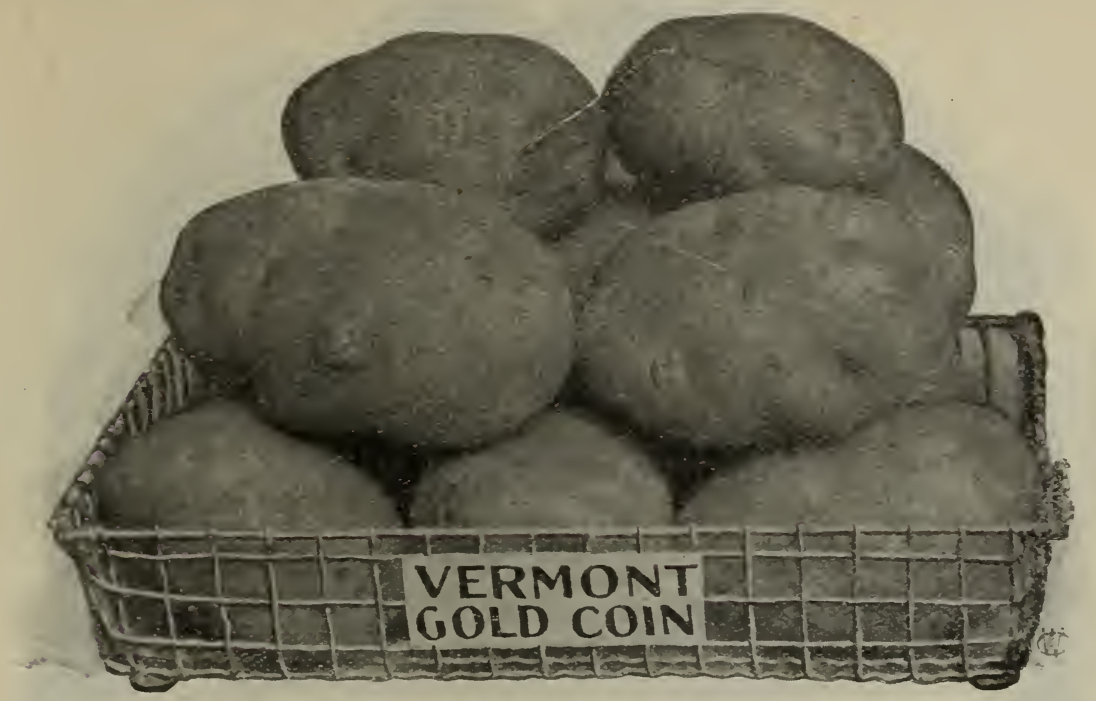

\section{VERMONT GOLD COIN.}

This is fast lecoming one of the great potatoes of the age. It is a main-crop variety, introduced by Burpee in 1903, with a very strong endorsement from the veteran potato specialist. Mr. E. L. Coy. Mr. Coy figured the yield a third more than Carman, Rural, Empire State, ete. Our own growers all fell in love with it because it filled the wagon box so fast. It is a very strong grower, vines very large, with deep green foliage covering the ground. The potato is pure white in color, with netted skin, somewhat subject to scab if planted on old land. Not as smooth as the Rural type varieties, but of rather better quality, cooking up dry and mealy even when very large and overgrown. As a cropper it is a leader and comes as near being blight-proof as anything we have.

Prices: Pk., 50c; bu., $\$ 1.40 ;$ bbl., $\$ 3.00 ; 5$ bbls. at $\$ 2.85 ; 10$ bbls. at $\$ 2.75$.

A. L. Young, Wakefield, Kan., writes, Oct. 21, 1906: "The Vermont Gold Coin I got from you last spring did finely. They are the largest potatoes I ever raised. Every one that sees them thinks they are Colorado potatoes.'

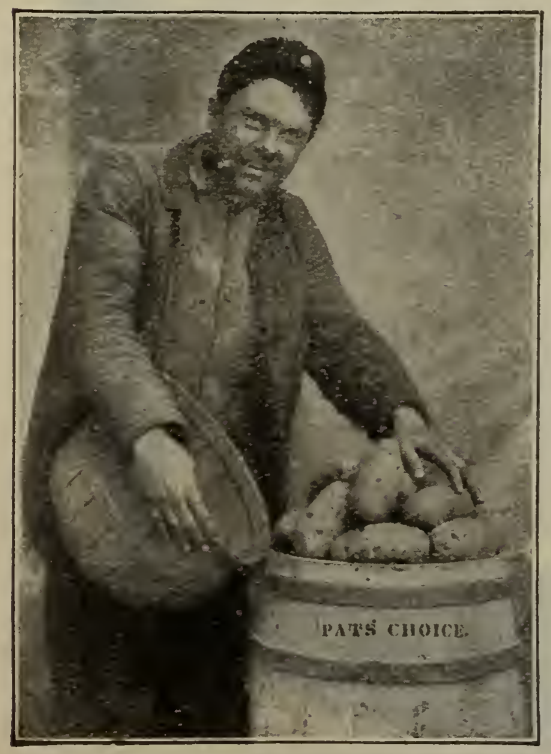

F. A. Snell, Milledgeville, Ill., writes, Marcl 12, 1906: "I have been getting potatoes of you for several years. I prize the Eureka and Gold Coin bought of you last spring very highly."

\section{PAT'S CHOICE.}

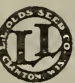

The most famous of all our introductions. TVe introduced it in 1900 as "The Greatest of All Late Potatoes,', basing this claim on the fact that "it outyields the Rural type varieires and is of better quality." These statements still stand all right, although we admit that Pat's Choice is not as good a seller as the Rural varieties, owing to its shape and color. Pat's Choice is the potato that is "different." There is nothing like it. Long, handsome and smooth. No other potato has such shallow eyes. Skin is a beautiful pink color, with deeper colored eyes, very thickly netted, and for quality-well, there is no potato like Pat's Choice for fine cooking qualities, always dry and mealy whether baked or boiled. It is medium late in season, a seed. ling of Seneca Beauty, which it somewhat resembles, but is earlier and does not boil to pieces as its parent does. To crown all, it is tremendously prolific. So now, if you want a thoroughly tried novelty, one that is on top for quality, on top for smoothness and handcome appearance, and on top for yield, choose Pat's Choice.

We have a fairly good stock of Pats this rear, but the demand is always so great we shall probably be out before the season is over. Therefore get your order in early.

Prices: Pk., 50c; bu., $\$ 1.50$; bbl., $\$ 3.25 ; 5$ bbls. at $\$ 3.10 ; 10 \mathrm{bbls}$. at $\$ 3.00$.

Our prices on potatoes are made just as low as is consistent with first-class stock at the time of writing this catalogue, but if later on market prices should decline and so our prices seem too high, write us and we will try and quote lower. Write us anyway if you need a large quantity, stating just what you exject to want. 


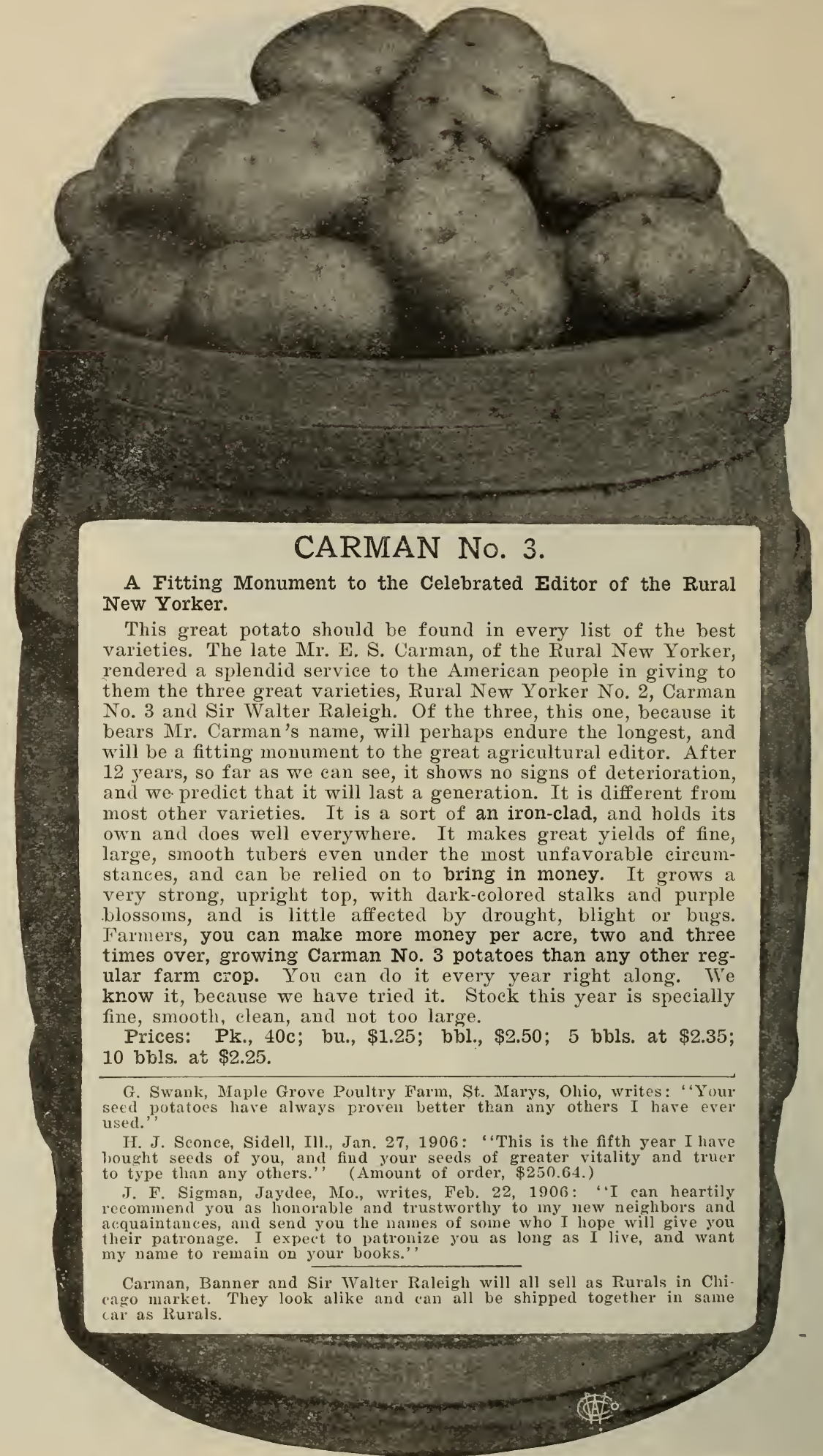

For pound, three-pound and half-peck prices, see page 29 . 


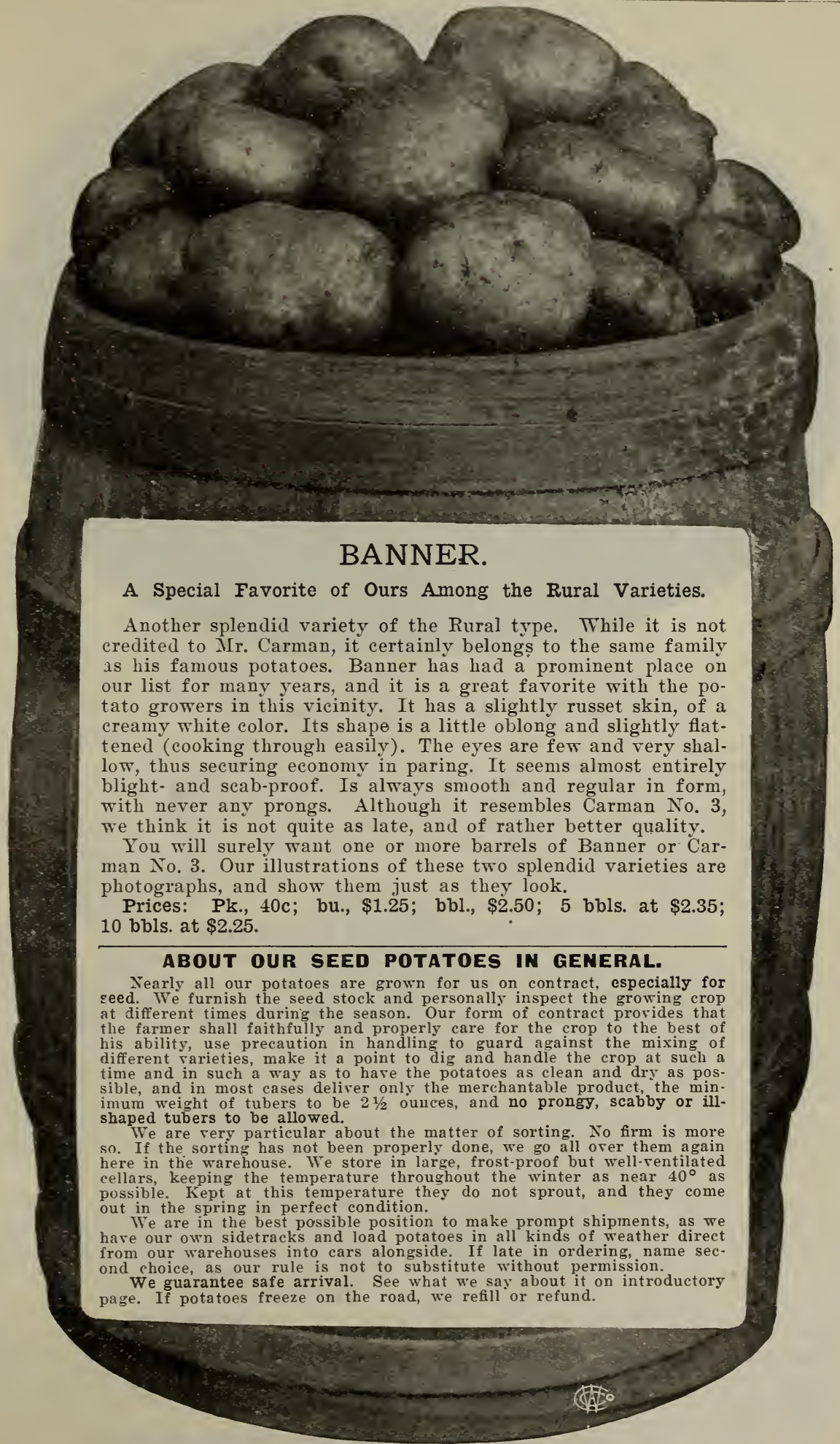

We pack all early shipments in lined barrels without extra charge. 


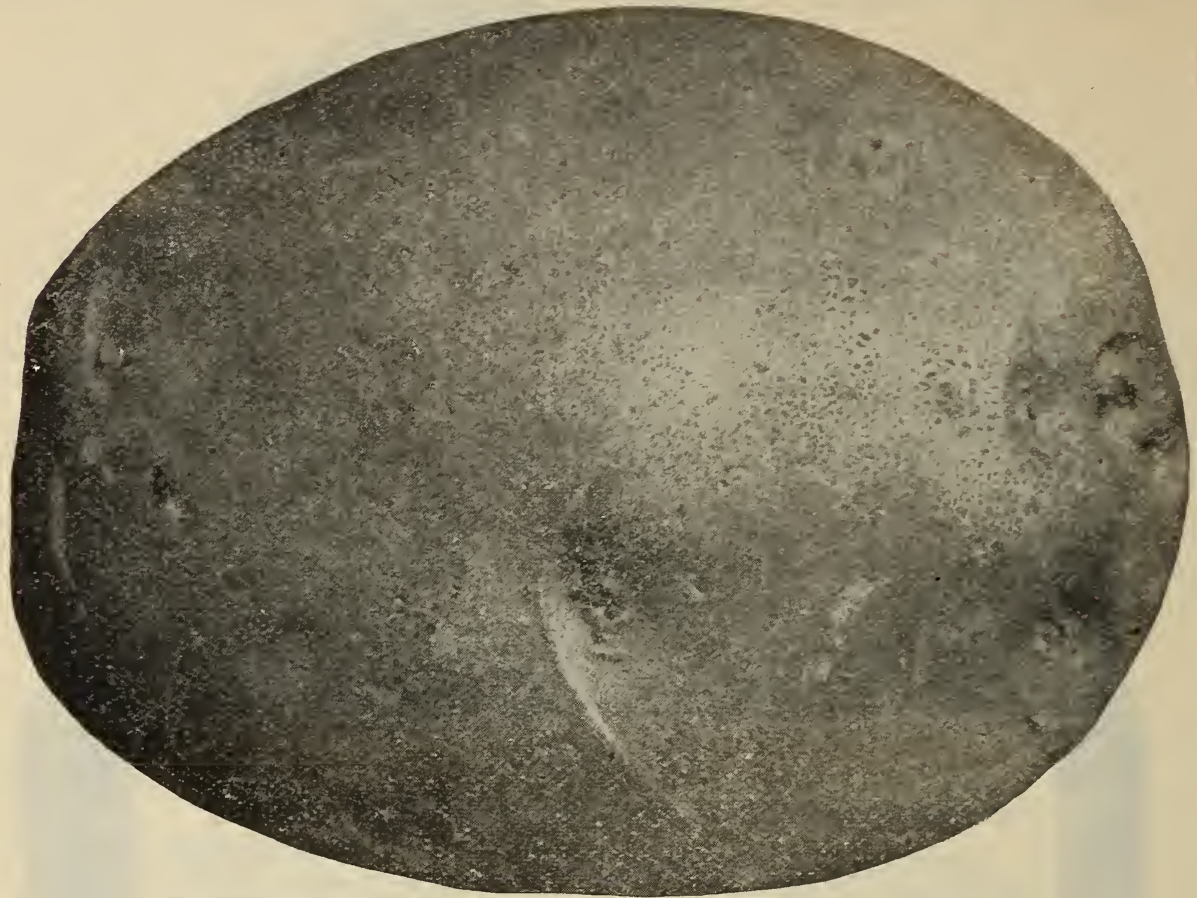

Rural New Yorker No. 2. Best seller in all Markets.

\section{RURAL NEW YORKER No. 2.}

Well known now the country over, and very largely planted for a profitable main crop. "Dusty Rurals', always bring the top price in Chicago market.

When Rural No. 2 first made its appearance in 1889, it introdnced an entirely distinct class of potatoes, unknown up to that time. The class is characterized by a long, rather spindling vine, with dark-colored stalks, dark green leaves and purple blossoms, tubers nearly round, flattened, with very'smooth, pure white skin, uniform in size, numerous in the hill, very attractive.

Send to us if you want genuine Rurals. Our stock is pure, clean and healthy.

Prices: Pk., 40c; bu., \$1.25; bbl., $\$ 2.50 ; 5$ bbls. at $\$ 2.35 ; 10$ bbls. at $\$ 2.25$.

\section{SIX GOOD MAIN.CROP VARIETIES.}

We have but a limited quantity of the following six varieties. They are all heavy-yielding medium late sorts and most of them are of recent introduction.

Prices for all, while our stock lasts: Pk., 50c; bu., \$1.40; bbl., \$3.00; 5 bbls. at $\$ 2.85$.

\section{IONIA SEEDLING.}

Introduced three years ago by a New York firm. It is a heavy-yielding main-crop potato, pure white in color, nearly round in shape. It came from seed balls of the heaviest-yielding main-crop potatoes of modern times, Sir Walter Raleigh and Carman No. 3, although it is slightly different from those varieties in style and manner of growtl. A yield record of 500 bushels per acre is claimed for it. We find it a good one, and consider it a valuable acquisition.

\section{MANISTEE.}

This grows about the largest of anything on our list. It comes from the same people as the Ionia Seedling and was introduced at the same time. It is a seedling of Early Rose, but is not like it except in color. Tubers are broad and flattened and very large, usually but few in a hill. Vines are immense, strong and healthy, a big yielder of big potatoes. Fine for a show variety.

IMPROVED JERSEY PEAGHBLOW.

A red-skinned late potato similar in appearance to the old Peachblow. It came to us last spring highly recommended, but as a yielder it rather failed to make good. We offer it for trial.
MONTANA PRIZE-TAKER.

A very large, white potato, oricinally from Montana It is one of the heaviest growers we have, with large, strong, vigorous vine, and gives an extraordinary yield of handsome white potatoes. Not as smooth as Carman and Sir Walter Raleigh, but of rather better quality. This is the third year we have offered this variety. It seems to have pleased our customers, as several have spoken of good results obtained.

\section{LIVINGSTON.}

Introduced in 1896 by A. W. Livingston's Sons as "A White Seneca Beauty." It is a very handsome potato, white-skinned with pink eves, skin well netted. It is rather long in shape, often grows very large, a great yielder, and of the very best quality. It has long been a favorite variety of ours.

\section{SNOWBALL.}

A pure white, round to oblong potato intro. duced two years ago by an Eastern seed louse as a "blight-proof" and "rot-proof" maincrop variety. We have found it a big yielder and a good one, but have rery few to offer this year.

See pages 9, 10 and 11 for the Best Newer Varieties of Potatoes. 


\section{POUND, THREE-POUND AND HALF-PECK PRICES.}

The uniform prices of all our standard varieties potatoes (pages 19 to 28) are: By mail, postpaid: 1 lb., 25c; 3 lbs., 60c. (See "Potato Eyes by Mail,", below.) By freight or express, not prepaid: 1 lb., 15c; $\frac{1}{2}$ pk., $30 \mathrm{c}$.

(See pages 9, 10 and 11 for pound and half-peck prices of "'Potato Novelties.' )

\section{COLlECTION OFFERS.}

1. Collection Barrels. We offer a barrel made up of any two varieties potatoes on our list, half of each, at barrel rates, plus 15 cents for each barrel; three varieties, 55 pounds of each, at barrel rates, plus 25 cents for each barrel; eleven varieties, one peck of each, at bushel rates.

2. Collection Bushels (packed in strong boxes). We offer a bushel of any two varieties, half of each, at bushel rates; four varieiies, one peck of each, at bushel rates, plus 15 cents for each bushel; eight varieties, $\frac{1}{2}$ peck of each, at peck rates.

3. Pound Collections. We offer one pound each, not prepaid, of any 10 varieties, for $\$ 1.00 ; 2 \pm$ varieties (our entire list), for $\$ 2.00$. We will not sell less than one pound of a variety.

The above Collection Offers are made for the accommodation of those of our customers who want to try several varieties in small quantities, and with a view to saving correspondence in quoting special prices.

\section{SECOND SIZE POTATOES.}

We hare some nice seconds to offer this year of some rarieties. Our second size potatoes are always in great demand and are invariably sold first They go further than first size. They really make re sort them, and for some varieties we would as soon plant them as firsts. They run from $2 \frac{1 / 2}{2}$ ounces (about the size of an arerage hen's egg) down to $1 \frac{1 / 2}{2}$ ounces, with occasionally one a little smaller still. They are smooth and clean, free from prongs and scab, and in fact are sorted by hand just as carefully as we sort our first size.

We offer these choice seconds of the following varieties at the prices named:

Improved Early Ohio and Early Acme at $\$ 2.25$ per bbl.; 5 bbls. at $\$ 2.15$.

Early Roser, Pingree and Vornehm at $\$ 2.50$ per bbl.; 5 bbls. at $\$ 2.40$.

(We will not sell less than one barrel of seconds of a rariety. If late in ordering, name a second choice, or give us permission to fill the order with firsts to the amount of the nomey sent. We have choice, or give us perio, Acme and Early Roser. Just a few barrels of seconds of most other varieties on our list, which we will quote on application. No seconds at all of any of the Rural type varieties, howerer, or of any Red Rivers.)

\section{POTATO EYES, POSTPAID, BY MAIL.}

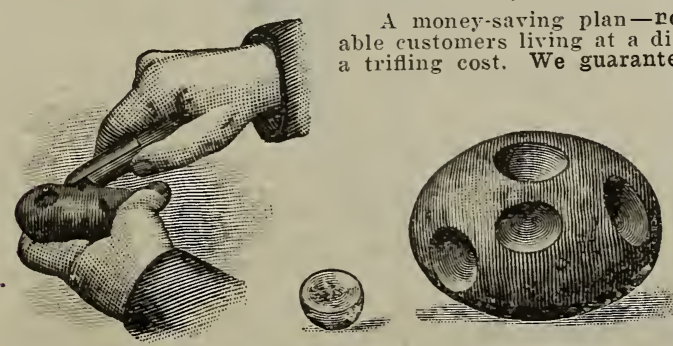

fance to test some of our choice potatoes at the safe arrival of each package in good growing condition. These collections of Potato Eyes are sent postpaid to any address in the United States, carefully packed in damp moss and oiled paper.

Our Mr. Wilson was one of the first to adopt this plan of sending Potato Eyes by mail. A collection of 160 eyes, under favorable circumstances, should produce a fine lot of potatoes. Mrr. Wilson has filled orders for eyes sufficient to plant 5 acres, all sent by mail. Orders from the south can be sent at almost any time during the winter with safety. Orders for the north and west will be booked when receired, and sent when the spring opens. We aim to send off Potato Eyes so as to reach customers at the right time for planting; if customers would designate time wanted when ordering, we would like it: if they should be receired too early, put in moist earth and place in cool location free from danger of freezing.

EARLY POTATO EYE GOLLEGTION.

160 EYES -40 each of any 4 rarieties

of early potatoes, your selection....\$1.00

\section{late potato eye collegtion.}

160 EYES -40 each of any 4 rarieties of late potatoes, your selection.....\$1.00

Two full collections, one of each, will be sent for $\$ 1.90$, postpaid. Or 40 eres each of two early and two late, 160 in all, for $\$ 1.00$.

Jas. J. H. Gregory, the seedsman, of Marblehead, Mass., writes, Oct. 24, 1906: "Planted a package of the potato seed obtained from your firm last spring and had rather remarkable results, one of the vines yielding 8 tubers of marketable size and another vine a tuber which weighed just a pound."

F. S. Fesler, Anderson, Ind., writes: "I reF. S. Fesler, Anderson, Ind., writes: "I re-
ceived the potato eyes and they are all right and have them planted. Thanks for the same.'

\section{HYBRIDIZED POTATO SEED.}

We offer a fine stock of choice potato seed, from which new varieties are produced. Experi-

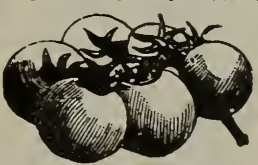

Potato Balls. menting with this seed is very interesting work. Sow early in the house and transplant the same as tomatoes. Every seed makes a distinct rariety - the little tubers the first year are about like marbles. Pkt., 15c; 2 pkts., 25c.

Dan Churchill, Alexis, Ill, writes, March 28 , 1906: "The potatoes at hand all right and full weight. I weighed them. Well pleased. My wotato seed you sent me is growing nicely. I potato seed you sent me is growing nicely. I
sowed them in a box. When I want seeds again you are my man,

John M. Gunn, McNabb, Ill., writes, April 7, 1906: "The potatoes arrived today in good shape, and are better than I expected from your description of seconds.' 


\section{WISCONSIN GROWN SEED CORN.}

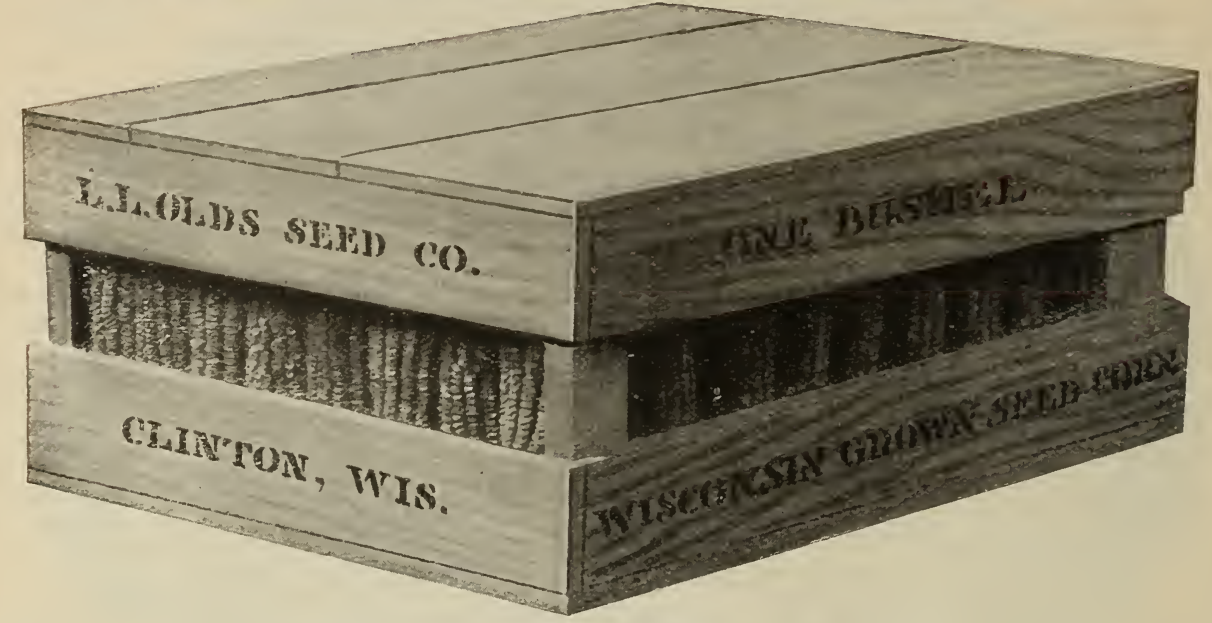

\section{ABOUT OUR SEED CORN.}

CORN ON THE EAR.-The above is a halftone illustration of a bushel crate of our Fire-Dried Wisconsin-grown Seed Corn ready for shipment. We have been putting up our corn in this way for two years. We shall certainly continue the plan, as our customers like it. The most progressive farmers want to see their seed corn before it is shelled, and it is right that they should. All the Agricultural Colleges now recommend buying on the ear. It is more work to handle the corn in this way, but we have some nice ears to offer, and we really want our customers to see them. Of course they are not quite equal to the big ears grown in the corn belt, but they are splendid for Wisconsin.

ADAPTABILITY.-More important by far than the looks of seed corn is the question of adaptability. Select varieties adapied to your latitude. Then insist on knowing where the seed was grown. Do not buy of a seedsman who does not tell where his corn grew. If you live in a northern latitude, look out for seed corn grown south of you.

OUR GUARANTEE. - Note what we say about guaranteeing quality on the second cover page. This applies to corn, as well as other things. If our corn fails to grow and make a good stand under ordinarily favorable conditions, we refund your money. You can rely on the seed if it comes from us. We test every lot of corn carefully and most lots several times. We must know positively that it tests well before it leaves our hands. At the same time we are glad to have our customers order in time to test the seed themselies. No chances should be taken with seed corn. There is too much at stake.

All our home-grown corn is fire-dried and very carefully selected. We are very particular about the selecting, altogether too particular our growers think. We allow the farmers to bring us only choice, select ears; then as it comes in we sort again ourselves and send back all that we do not like. When we take it from the drying room it is again carefully inspected and imperfect ears thrown out. If we shell the corn we tip it by hand before shelling. This makes a lot of extra work, but it pays. Any farner could well afford to pay three times the price we ask in order to secure olds' Select Home Grown Seed Corn. It is a shame that so much mixed up, carelessly grown stuff should be sold every year for "Choice Seed Corn,", when it has not the slightest clain to the title. It may look all right in the bag, but no one can tell much about it there.

The Shelled Corn (Home Grown) that we offer is from ears saved for Ear Corn, bint at the last examination either were considered not quite perfect enough to go in the crates or had to be broken for further examination.

\section{SEED CORN PRIGES FOR 1907.}

The single ear, quart and half-peck prices of all varieties, unless otherwise given, are as follows:

By mail, postpaid: Sample ear, any variety, 25c; one quart, shelled, 30c.

By freight or express: Sample ear, 15c; qt., 15c; 1/2 pk., 40c.

See prices for larger quantities under each variety. Sample packets free on application to in. tending purchasers. Seê page 8 and next page for Free Sample Collection. Half-bushels shelled furnished at bushel rates. Not less than one bushel of a variety sold on the ear. No extra charge for crates and bags. Corn is shipped in seamless grain bags. Sample ear in every full bag.

\section{MURDOCK YELLOW DENT.}

\section{ADAPTED TO SOUTHERN HALF OF WISCONSIN.}

We recommended this variety of corn most highly last year, slowing it in colors. We think no less of it this year, only we like Clark's Yellow Dent a little better. (See page 2, also front cover.) Murdock is a very large variety for an extra early. Is well adapted to the southern lialf of Wisconsin, the northern edge of Illinois, northern Iowa, southern Minnesota and similar latitudes. We call it a 90-day corn. It is as early as Pride of the North, and much larger. The ears average 8 to 9 inches in length, are very symmetrical in shape, with good tips, always well filled out, and with 16 to 20 rows of corn each. Kernels are set very compactly on the cob, something like Reid's Yellow Dent, generally smooth on the outer ends, but of unusual length for a smootli corn. Color of the corn is a uniformly bright golden yellow. As a yielder it is way up, almost equal to Reid's Yellow Dent and other big yielders. Size of stalk and growth medium, not nearly as large as Reid's and not quite as large as Clark's.

Murdock Yellow Dent is not a new variety, as it has been grown and improved by selection right here in Wisconsin for a long term of years. It is sometimes called Wisconsin Yellow Dent. We recommend it as a reliable, sure-to-mature, well-developed and uniform Yellow Dent. Our seed is all grown here, fire-dried and carefully selected.

Prices-Ears, in bushel crates: 1 bu. ( $70 \mathrm{lbs}$ ),$\$ 2.75 ; 5$ bus. at $\$ 2.60 ; 10$ bus. at $\$ 2.50$.

Shelled: Pk., 75c; bu. (56 lbs.), $\$ 2.50 ; 21 / 2$ bus. or over at $\$ 2.25$. 


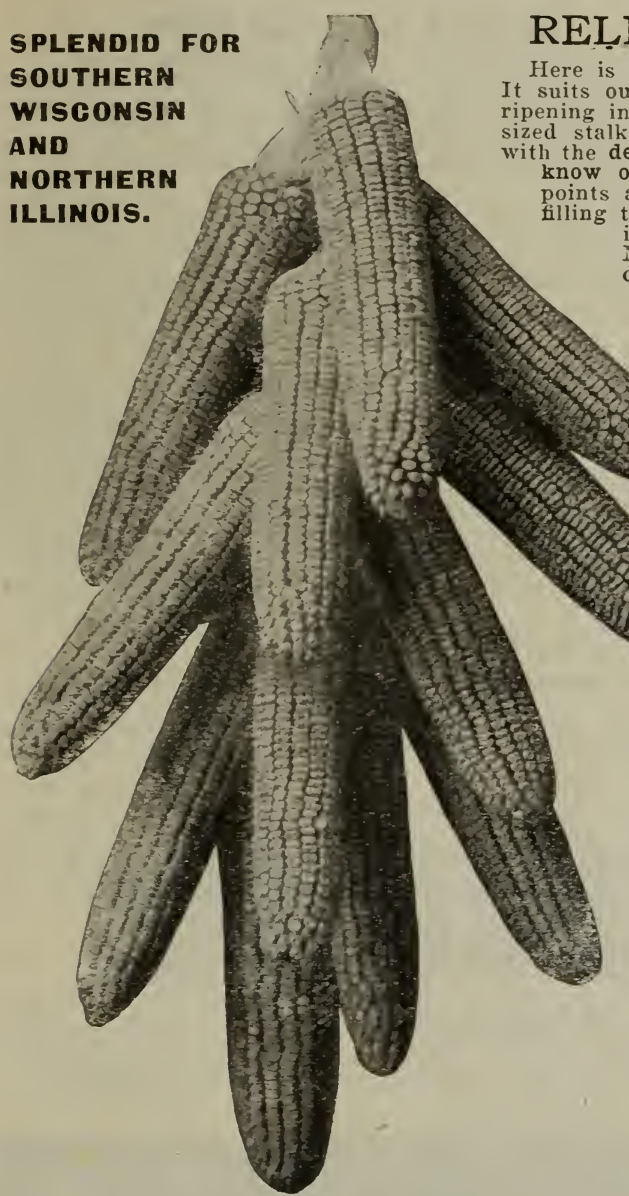

12 Ears of Reliance Yellow Dent.

\section{IMPROVED TWELYE.ROWED FLINT.}

Twelve-rowed corn vields more per acre than 8rowed. The ears are larger in circumference and have row more corn on them. For this rearly feed. Twelveare planting it for the silo and for early fll known Long. Rowed Flint is a selection from the well known Longfellow Flint or Yankee Corn. It is just as early as Longfellow and hast c llor. The one objection to short. By careful selechas been that the ears were too short. By careful selection, we have materially lengthened the ears, so that now we have it nearly as long as the original

fellow. All the stock we offer is home grown. $\$ 2.60$

Frices-Ears: 1 bu., $\$ 2.75 ; 5$ bus. at $\$ 2.60$. $21 / 2$ Shelled: $1 / 2$

lus. 2t $\$ 2.25$. Fight. Rowed Yellow Flint (Longfellow) at the same prices.)

\section{OLDS' MAMMOTH FLINT.}

A new variety of rery large red flint corn introduced by us three rears ago. Henry Field, the corn specialist, calls it the largest of all fints, and that is what it is. Our crop failed us and we have only a few bushels to offer. What we have is home grown.

Prices, same as for Improved Twelve-Rowed.

(See what we say on opposite page about the homegrown shelled corn we offer, also about our methods of loandling corn and our guarantee. Send your order to us and we will take care of you. We will not substi. tu e without permission. If late in ordering, name a second choice.) in this county by crossing Iowa Gold Mine with Murdock Yellow Dent. It was introed by ns 9 years ago and has become a great favorite with the farmers of this section.

We recommend it as, in our judgment, about the most satisfactory all-round corn for this latitude right liere and the section for 100 miles suuth of us. It is a week or ten days later than Murdock Yellow Dent, and while not so very much larger, it produces an immense amount of shelled corn to the acre, on account of its unusually deep kernel. It makes handsome shelled corn. Another thing, it does not run to flinty kernels at the tips, so objectionable in Reid's Yellow Dent. Our stock is all home grown, opposite page, Don't plant your mixed-up corn again, when you can get pure, select seed at the prices for which we offer it.

Prices, same as for Murdock Yellow Dent (see opposite page).

FREE SAMPLE COLLECTION.

(See page 8 for further explanation of this Collection.)

Olds' New Barley (Oderbrucker). Pages 4 and 5.

Swedish Select Oats (Wisconsin No. 4). Pages 6 and 7

Clark's Improved Yellow Dent Corn. Page 2. Silver King Corn (Wisconsin No. 7). Page Kubanka Macaroni Wheat, No. 5639. Page 37 White Hulless Barley. Montana grown $P 3.5$ Alfalfa. Choice American (Utah) seed. P. 8. Medium Red Clover. "Old Gold" brand. P. 42. Alsyke Clover. "Old Gold," the best. P. 42 Timothy. Clean, home-grown seed. Page 43.

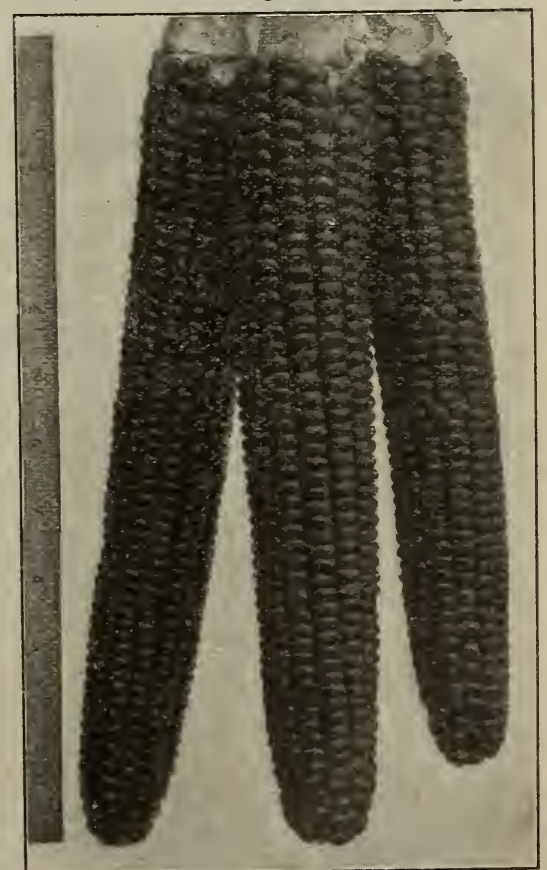

Improved Twelve-Rowed Flint. 


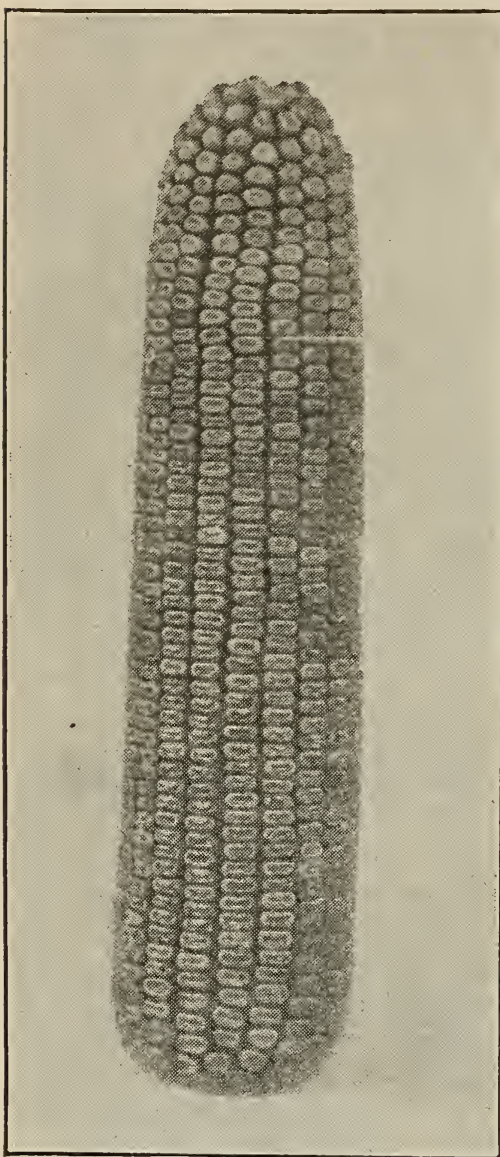

Prize Ear Reid's Yellow Dent at Iowa State Fair.-Courtesy of Wallace's Farmer.

Greatest White for the Corn Belt.

Silver Mine holds nearly the same place among white dents throughout the corngrowing states that Reid's Yellow Dent occupies among the yellow dents. It is a prize-winner and lias made some great yield records. 215 bushels were grown on one acre by an Iowa farmer in 1896, which is the world's best yield record from one acre of any sort or color.

This corn, like Reid's Yellow Dent, originated in Illinois, although first introduced by an Iowa seed house. It is a pure white corn, with large ears often measuring 10 to 12 inches in length and weighing as high as $11 / 2$ pounds each. The ears are very uniform in size and shape, with 16 to 20 straight rows of very deep kernels set on a small white cob. Kernels are of unusua length, usually rough at the outer ends, and ears are splendidly filled out at the tips. The corn matures in about 100 days and can be grown successfully elear to the northern boundary of Illinois.

Our main stock of Silver Mine is from Mr. Young, who grew our Reid's Yellow Dent, and is equally choice. See what we say about his methods above. The illustration at the right is a photograph taken in Mr. Young's drying house in November, 1906. It shows the ears inserted in wire poultry netting, giving a fine opportunity for circulation of air all around and between the ears.

Prices, Mr. Young's Silver Mine, sam as for Reid's Yellow Dent.

\section{REID'S YELLOW DENT.}

Most Popular Yellow Throughout the Corn Belt.

Reid's Yellow Dent is doubtless more largely grown all through the corn belt than all otler varieties of yellow corn combinel. It is always a prize-winner at Illinois State Fair and the other great corn shows, and in fact, carries off most all of the premiums offered for Yellow Dents.

The ears are long, 10 to 12 inches, and the kernels quite thick and very compact in the row, making it a very solid corn. Color, a deep golden yellow. Stalks are very large and tall, in fact, most too large to cut up. It matures in about 100 to 105 days, and throughout the corn belt is considered an early variety. The prize ear at Iowa State Fair last fall, shown on this page, is a typical ear of this variety of corn and as fine a specimen as we ever saw.

The Reid's Yellow Dent that we offer this year was grown in Stephenson County, Illinois, just below the Wisconsin state line and only about 10 or 15 miles south of us. It is therefore practically home grown. All of this corn was grown, selected and fire-dried by Mr. R. A. Young, an enthusiastic corn breeder. Mrr. Young follows the plan of detasseling every other row, as recommended by Prof. Holden, of Iowa, and he also grows his stock seed very carefully in breeding plots, after the plan of the Illinois Corn Breeders' Association.

Prices-Ears: 1 bu., $\$ 2.75 ; 5$ bus. at $\$ 2.60 ; 10$ bus. at $\$ 2.50$.

Shelled (from ears saved for ear corn): Pk., 75c; bu., $\$ 2.50 ; 2 \frac{1}{2}$ bus. or over at $\$ 2.25$.

\section{IMPROVED PRIDE OF THE NORTH.}

Pride of the North is a well-known, very early Yellow Dent. Cobs are rery small and kernels long, so that while the ears are not large, the proportion of shelled corn is very great. Our Improved Pride of the North is from Putnam County, Ill., about 100 miles south. It is much larger than ordinary Pride. It is, in fact, quite a different variety from the old Pride of the North, and should not be confused with it. We think it much superior to that well-known sort. Ears average at least 9 inches. A most desirable, sure-to-ripen variety for latitude of northern Illinois.

Prices-Ears: 1 bu., $\$ 2.25 ; 5$ bus, at $\$ 2.10$.

Shelled: Pk., 65c; bu., $\$ 2.00 ; 21 / 2$ bus. or over at $\$ 1.75$.

(When ordering corn, name second choice, as we may be out of the variety you call for. We always run short of home-grown corn before the end of the season. See pages 2 and 3 for our new Wisconsin varieties. Next page for cheaper corn.)

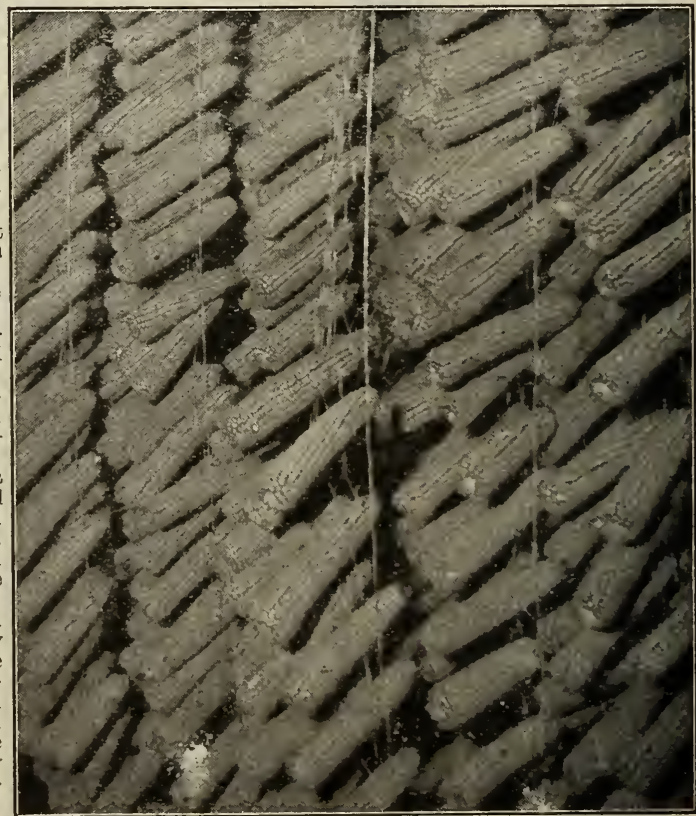

Ears of Iowa Silver Mine in Mr. Young's Drying House. 
Our stock of the first five varieties on this page was grown in northern Ohio, by one of the oldest, as well as largest and most famous breeders and growers of seed corn in the Únited States. This corn is all shelled, but is an extra choice grade, and must not be eonfused with the ordinary commercial grade of seed corn sold by so many seedsmen. Each ear was tipped before being shelled, and it is all guaranteed to show a high germination test.

SIBLEY'S PRIDE OF THE NORTH.

The old, well-known standard extra early put out years ago by Hiram Sibley. A strictly 90-day corn. Ears not large, but kernels very deep with very small cob. Few rarieties will show as high a percentage of shelled corn. Our strain is a choice one, uniform in color and type, and our prices very low indeed for so choice a grade.

Prices-Ohio grown: Peck, 50c; bu., \$1.50; 21/2 to 10 bus. at $\$ 1.35 ; 10$ bus. or over at $\$ 1.25$.

\section{KING OF THE EARLIES.}

Spoken of as "Earliest dent corn in eultivation." splendid variety for farmers in extreme northern latitudes. Ears are medium in size, rather short, cobs small, elosely set with fair length kernels of a bright golden color. Stalks very leafy, furnishing excellen fodder.

Prices, Ohio grown, same as for Pride of the North. MINNESOTA KING (HALF DENT).

A cross between dent and flint. The ear is good-sized, 8-rowed, with small cob, and very large, broad kernels of a golden yellow color. Tery early. We recommend this corn for central and northern Wisconsin, Minnesota and the Dakotas.

Prices, Ohio grown, same as for Pride of the North.

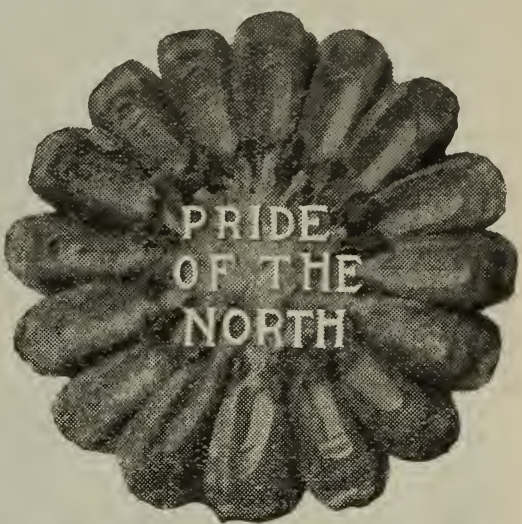

MPROVED LEAMING.

like Reid's popular of all dent varieties in the east. It is a large, heavy-yielding, yellow corn, much like Reid's Yellow Dent, but of a deeper yellow color, ears more pointed, and kernels wider and rougher and not usually as compact on the cob. Not recommended for the north, but a great variety for the corn belt.

Prices, Ohio grown, same as for Pride of the North.

See description on preceding page.

IOWA SILVER MINE.

Prices, Ohio grown, same as for Pride of the North.

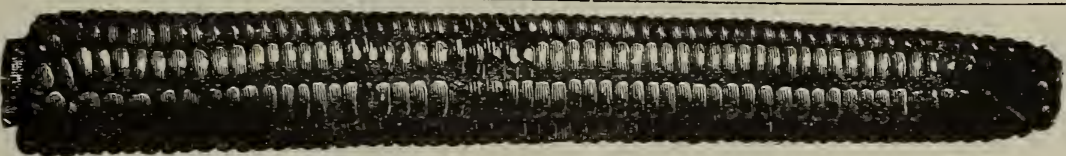

A Typical Ear of Early Longfellow Flint.

FLINT OR YANKEE CORN.

The following six varieties are perhaps the best known and most reliable sorts of flint corn. Flint is earlier than dent corn and is splendid for a fodder crop. Our stock of all these varieties is Nebraska grown.

EARLY LONGFELLOW (YELLOW YANKEE)

The most popular of all flint varieties. It is a beautiful 8-rowed yellow flint, with slender, straight ears, 10 to 15 inches long. Kernels are large and wide, and cob very small. Ripens in 75 to 85 days, and very prolific. Well adapted to the Northern States, and largely grown in Wis, and Minn.

Prices: $1 / 2$ pk., 35c; pk., 50c; bu., $\$ 1.40 ; 21 / 2$ bus. or over at $\$ 1.25$.

KING PHILIP (RED).

A very early 8-rowed red flint. Ripens in 80 days. Stalks are very leafy, splendid for feeding green or for silage. Extremely hardy and a good cropper on poor land.

Prices, same as for Longfellow Flint.

\section{EARLY GANADA.}

An extra early flint, specially valuable for northern Wisconsin and Minnesota. Ears are long, 8 rowed, of a clear yellow color. A popular variety.

Prices, same as for Longfellow Flint.

\section{ANGEL OF MIDNIGHT.}

An extra early 8-rowed Yellow Flint. Ears very perfect in shape, well filled out the entire length, 10 to 13 inches in length. Stalks of medium size.

Prices, same as for Longfellow Flint.

SANFORD'S WHITE. Handsomest of all Flints.

The ears are of unusual length, 12 to 15 inches, smooth and symmetrical in shape, of a flinty white color. Makes a very sturdy, vigorous growth, with broad and succulent leaves. Stalks usually have 2 or 3 ears each. Our stock of this and of North Dakota Flint is more select than of the others.

Prices: $1 / 2$ pk., $40 \mathrm{c}$; pk., $60 \mathrm{c}$; bu., $\$ 1.50 ; 21 / 2$ bus. or over at $\$ 1.35$.

\section{NORTH DAKOTA WHITE FLINT.}

A careful selection for many years of the well-known Squaw corn. Very much better than Squaw. Stalks 5 to 6 feet in height, with beautiful, medium-length ears. Our seed is very select. Prices, same as for Sanford's.

GIANT RED-COB ENSILAGE. Greatest of all Fodder Varieties.

A pure white wh with red wh wh of fow der per acre. It is sweet, tender and juicy, and furnishes more nourishment than any other variety.

No dairy farmer should be without it. It can be fed green or made into silage, or cured and stacked.

We have a fine lot of seed of this largest and most famous of all varieties of fodder corn. Drill in

rows $31 / 2$ feet apart, $1 / 2$ bu. of seed per acre, or more if a large amount of leafy fodder is desired with smaller growth of stalk.

Prices: $1 / 2$ pk., 35c; pk., 50c; bu., $\$ 1.40 ; 21 / 2$ bus. or over at $\$ 1.25$.

\section{EVERGREEN SWEET FODDER CORN.}

A fodder grade of the famous Stowell's Evergreen Sweet Corn. For description, see page 53

Stalks are very sweet. rich and tender, produeing the best fodder.

Prices: 1/2 pk., 40c; pk., 60c; bu. (measured), $\$ 1.60 ; 2 \frac{1}{2}$ bus. or over at $\$ 1.45$.

(For Garden Sweet Corn, see pages 13, 52 and 53; Pop Corn, page 56.) 


\section{NORTHERN GROWN SEED GRAIN.}

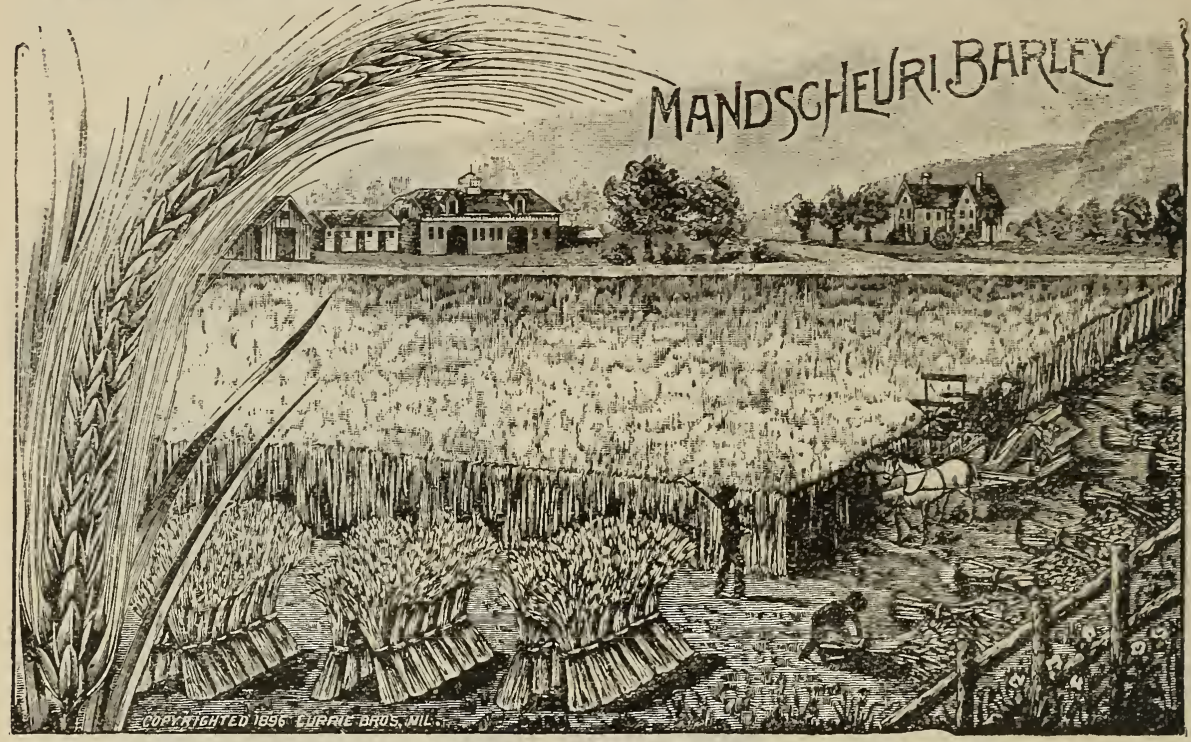

\section{MANDSCHEURI BARLEY. THE BEST STANDARD VARIETY.}

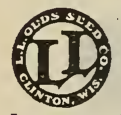

With the exception of the new Oderbrucker (see pages 4 and 5 ), there is no barley that will compare with the Mandscheuri for a reliable money-making variety. It is an early, six-rowed barley that grows very vigorous and strong, bearing long, well-filled heads of plump grain. The strong root formation and large, stiff straw have always been characteristics of this barley, and for yield it beats them all.

Mandscheuri is an improved strain of Manshury, but makes a stronger growth, has a plumper berry, and usually yields 10 to 15 bushels more per acre. The original seed was procured by the Wisconsin Ex. Station from Russia, and was first sent out by the Station in 1895. In the yield record at the Station farm it stands first out of 37 varieties for a term of years, and it has doubled the yield of many common varieties. The professors at the Ex. Station, and Agricultural leaders of Wisconsin generally have done all that they could to induce farmers everywhere to sow this barley and have all the time recommended it unhesitatingly. It is perhaps not too much to say that this variety of barley has been worth millions of dollars to the farmers of Wisconsin alone.

Prof. Zavitz, of the Ontario Agl. College, says Mandscheuri gave an average of 70 bushels and Manshury an average of 59 bushels per acre during a period of 16 years, a difference of 11 bushels per acre in favor of Mandscheuri.

It has been a leader. with us for a long time and we sell thousands of bushels of Mandscheuri to our custon:ers every year. We grow our stock right here, as we are right in the midst of a great karley section. For that reason we are able to make lower prices than other seedsmen. Our stock this year, although slightly colored, is plumper than we have seen it for several years. It is clean and heavy and splendid seed, practically free from smut and oats. Order of us and you will le sure to get the genuine Mandscheuri.

Prices: Pk., 30c; bu. (48 lbs.), 90c; 2 to 10 bus. at $75 \mathrm{c} ; 10$ to 50 bus. at $70 \mathrm{c}$; 50 bus. or over, prices on application. Prices include heavy jute kags.

\section{BLUE RIBBON BARLEY.}

A new six-rowed barley, introduced two years ago by a well-known Minnesota seed house. It out. It contains an nnusual percentage of saccharine matter: in fact, more, it is claimed bv the introducers, than any other barley. This makes it of very great value. Our growers here have been well pleased with it. This last season we could not see that it was very much different from Mandscheuri, but in 1905 it outyielded Mandscheuri by at least 10 to 15 bushels per acre and it was plumper. It seems to be fully equal in every other respect to that well-tested and thoroughly reliable variety, and it is certainly worthy of trial.

Prices: Peck, $35 \mathrm{c}$; bu., $\$ 1.00 ; 2$ to 10 bus. at. $80 \mathrm{c} ; 10$ bus. or over at $75 \mathrm{c}$.

\section{NEW HANNA BARLEY.}

A new variety of 2 -rowed barley recently introduced by the U. S. Dept. of Agriculture. It is a pedigree variety from Europe, and is spolien of as "the great favorite barley among German and Austrian brewers.' It is not 6-rowed, like our other varieties, but 2 -rowed. Two-rowed barley is always plumper than 6-rowed, and the very plump kernels are a distinguishing characteristic of the Hanna. This barley was awarded gold medal at St. Louis. It is grown and highly recommended by several agriculturists of national reputation. Prominent seedsmen are listing it at high prices. It is also called Moravian barley. Is noted for its earliness and mealiness of grain, as well as its plumpness of kernel and heavy vielding capacity.

Prices, same as for Blue Ribbon. 
WHITE HULLESS BARLEY.

No Beards or Hulls. Great for Feed.

White Hulless is different from any other barley. The grain looks like wheat. It is al most as heary as wheat, equal to wheat in feeding value, and will yield nearly twice as much. It succeeds in all barley-growing regions, and also in sections where common barley is not grown at all. It is very early, thus making a splendid nurse crop for seeding with elover; is entirely beardless, with soft straw, splendid for feed. Many farmers cut it for a hay erop. It vields as high as 60 bushels per acre, and for feeding value is not surpassed by any other grain. Sow $1 \frac{1 / 2}{2}$ bushels per acre and treat just as you would any otlier barley. Specially fine for poultry and for grinding for hogs. One man says:

"I fattened 20 logs with it for one butcher, and made a gain of 106 pounds to the hog in five weeks. It makes sweeter meat than corn." As usual, we have some beautiful White Hulless to offer our customers this year. It is Montana grown, is not colored at all, and is just as nice as the stock we have had in previous years, which our customers know is saying a great deal. We will send a small sample free to any one who asks for it. When you see it, you will want to order.

Prices (Montana grown): 1/2 pk., 30c; pk., $50 \mathrm{c} ;$ bu. (48 lbs.), $\$ 1.75 ; 2$ to 10 bus. at $\$ 1.50 ; 10$ bus. or over at $\$ 1.40$. (Prices of Hulless include regular cotton grain bags.)

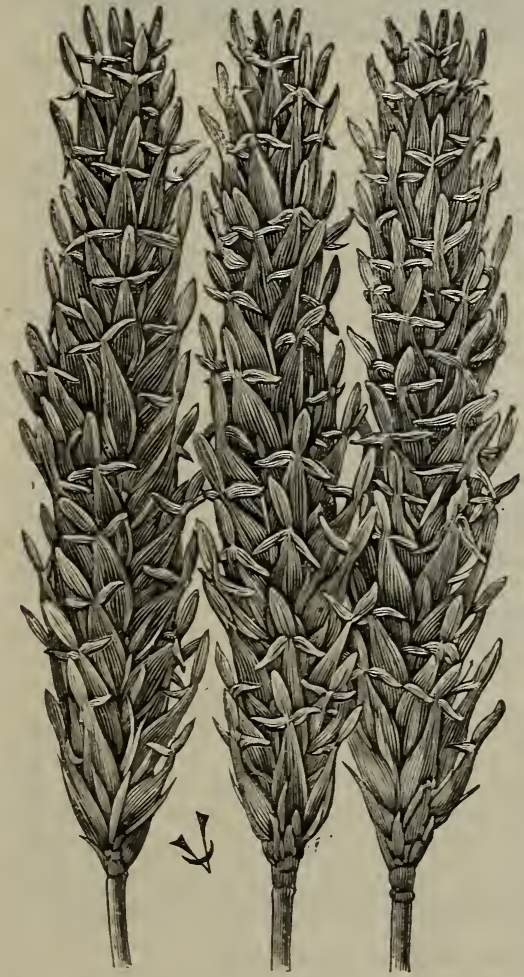

Champion Beardless Barley.

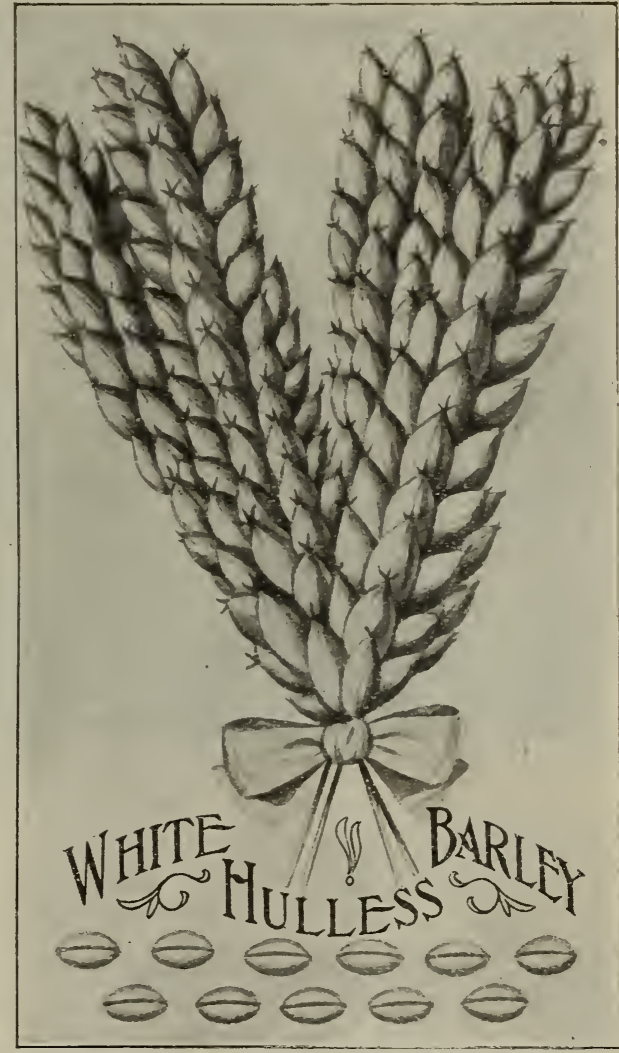

\section{CHAMPION BEARDLESS BARLEY.}

No Beards and Never Any Smut.

The Champion is an improve 1 beardless barley. It is similar to Success Beardless, but is larger, has a longer straw, and yields more per acre. It is literally beardless, just as represented, and this point alone is enough to recommend it, as it is pleasant to handle, and the straw can be fed to stock without fear of injury. While growing, it looks like wheat, but after being threshed looks much like other barley. It is earlier than any bearded barley, better to seed with, better for feeding, usually yields as well, and seems to be smut-proof. We never have seen a particle of smut in a field of beardless barley. We are headquarters for this variety of barley. Have grown it for sereral years and we supply other seeds men. The stock we offer this year is plumper and nicer looking than usual, and while a little colored, is brighter than most years. Beardless barley alwars colors more easily than bearded.

Just one more word. If you should find an occasional bearded head in your field, don't blame us and say the seed was mixed. The fact of the matter is, beardless barley tends to revert back to bearded. The Experiment Stations say this. We used to handpick our beardless barley, going through the fields and cutting out the bearded heads in order to have our seed pure. Then we could not understand why beards appeared occasionally

Prices: $1 / \mathrm{pk}, 25 \mathrm{c}$; pk, 35c; bu., $\$ 1.25 ; 2$ to 10 bus. at $\$ 1.00 ; 10$ bus. or over at $90 \mathrm{c}$.

\section{JAPANESE BUCKWHEAT.}

A popular early variety of buckwheat. It grows a large, heavy straw, with many branches, and succeeds well in the extreme north. About a week earlier than Silver Hull. The grain is very large, of dark brown color.

Prices: Pk., 40c; bu. (50 lbs.), \$1.25; 2 bus. or over at $\$ 1.10$.

(Buckwheat prices include regular grain bags.)

\section{SILVER HULL BUCKWHEAT.}

The best variety in our estimation. It has a rather small grain, light gray in color, nearly round in shape. Our farmers here are sowing Silver Hull quite generally now in preference to Japanese, as it not only sells better, but they claim it vields more. We have a large stock to cffer this year of fancy seed, grown right here at Clinton. Prices, same as for Japanese. (Special prices on large quantities. Samples free.) 


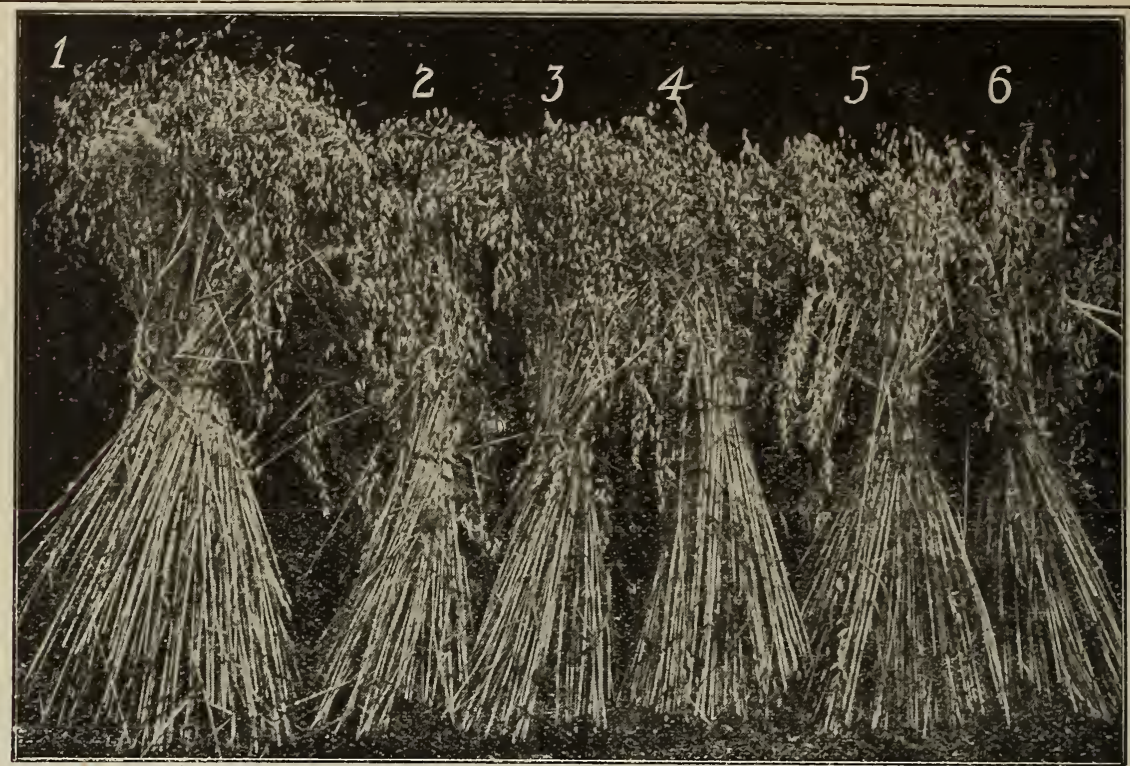

Showing Comparative Length of Straw of our Six Varieties of Oats as Grown by Mr. J. R. Lawrence, of Massachusetts.

J. R. Lawrence, the famous experimenter, reports as follows on varieties of oats tested for us: "No. 1. The Johnson. Best all-round oat of six varieties this season, straw and oats considered. Very elosely resembles Big Four, save was taller.

No. 2. National. Second in list and value. Straw stiffer and shorter than Johnson, yield same.

"No. 3. Swedish Select. Heaviest yielder (by measure) of any of the varieties. Straw stiff, stands up well in storm. Did not stool as well as Johnson, but better than National.

"No. 4. Big Four. Splendid oats. Straw coarse, stiff, yield good but oats lighter weight than other varieties this season. All weighed over standard, 32 lbs. per bushel, however.

'No. 5. Silver Mine. Fifth in comparison to others, both as to straw and oats. Heads light. Straw broke down easily in wind and rain.

"No. 6. Black Tartarian. Heaviest single heads in the lot. This was the latest of the varieties grown: in fact, it was green when cut.

"All oats did exceptionally well. Were all above standard weight per bushel. All free from smut and rust. Yield averaged double what common seed oats purchased from granaries gave."

\section{JOHNSON OATS.}

A new variety that pleases us very well. It is a large, pure white oat with long grains; a very strong grower, medium in season, with good, stiff straw of unusual length. The originator, a Michigan man by the name of Johnson, has produced this valuable variety, not by cross-breeding, but by a systematic selection for a long term of years, until he now has an oat that for freedom from disease, productiveness, weight of grain and color is declared to be without a peer.

Notice Mr. Lawrence's report, placing. Johnson first in our list of varieties. Our stock this year is rather limited and the oats not as heavy as some of our other varieties, although they made a good yield.

Prices: 1/2 pk., 20c; pk., 30c; bu. (32 lbs.), $90 \mathrm{c} ; 2 \frac{1}{2}$ to 10 bus. at $75 \mathrm{c} ; 10$ bus. or over at 70c. Bags free.

\section{BLACK TARTARIAN OATS.}

Black Tartarian is later in ripening than any other variety of oats we have, and we are inclined to think has a stiffer straw than any other. Then it is black. In many sections black oats yield much better than white. These three points will recommend this variety to many of our cus tomers.

Black Tartarian comes originally from England, where they eall it "the hardiest and most productive of all oats." It has done well here, and we consider it a very valuable variety. Order early, as our stock is not large.

Prices, same as for Johnson oats.

\section{BIG FOUR OATS.}

A large, white oat that has been a much-valued variety with us for a number of years. It makes a large, vigorous growth, with strong straw, and has made some great yield records. Not as thick an oat as Swedish Select and a Jittle later in ripening, although not a late rariety. Mr. Law. rence calls it "splendid," with "coarse, stiff straw and good yield."' Our stock this year is somewhat colored.

Prices: Peck, 25c; bu., $75 \mathrm{c} ; 2 \frac{1}{2}$ to 10 bus. at $65 \mathrm{c} ; 10$ bus. or over at $60 \mathrm{c}$.

\section{SILVER MINE OATS.}

First introduced in 1895 . It is a plump, white oat: not quite as large grained as Big Four, but earlier. We never thought as much of it as we do today, as here in our section it did the best of anything last season. It may have been partly due to the way it was handled and the farm where it was grown. The oats are just slightly stained, but not enough to do any harm. They are the heaviest in weight of any we offer except Swedish Select. Our stock was grown on clay land.

Prices, same as for Big Four.

SWEDISH SELECT (Wis. No. 4). The best variety in America today in our estimation. See pages 6 and 7 .

NATIONAL OATS. Without doubt the same thing as Swedish Select. For that reason we do not describe it separately.

TREAT YOUR OATS FOR SMUT.

All the oats we send out are practically free from sinut, and have been thoroughly cleaned. We make a specialty of choice seed stock, and we think no better can be found anywhere, but we advise treating the seed if you want to keep them free from snut. We recommend the formaldehyde treatment, submerging the seed, before sowing, for ten minutes in a solution of one pint formalidehyde to 36 gallons of water. Do not neglect this if you want to keep your oats smut free. 


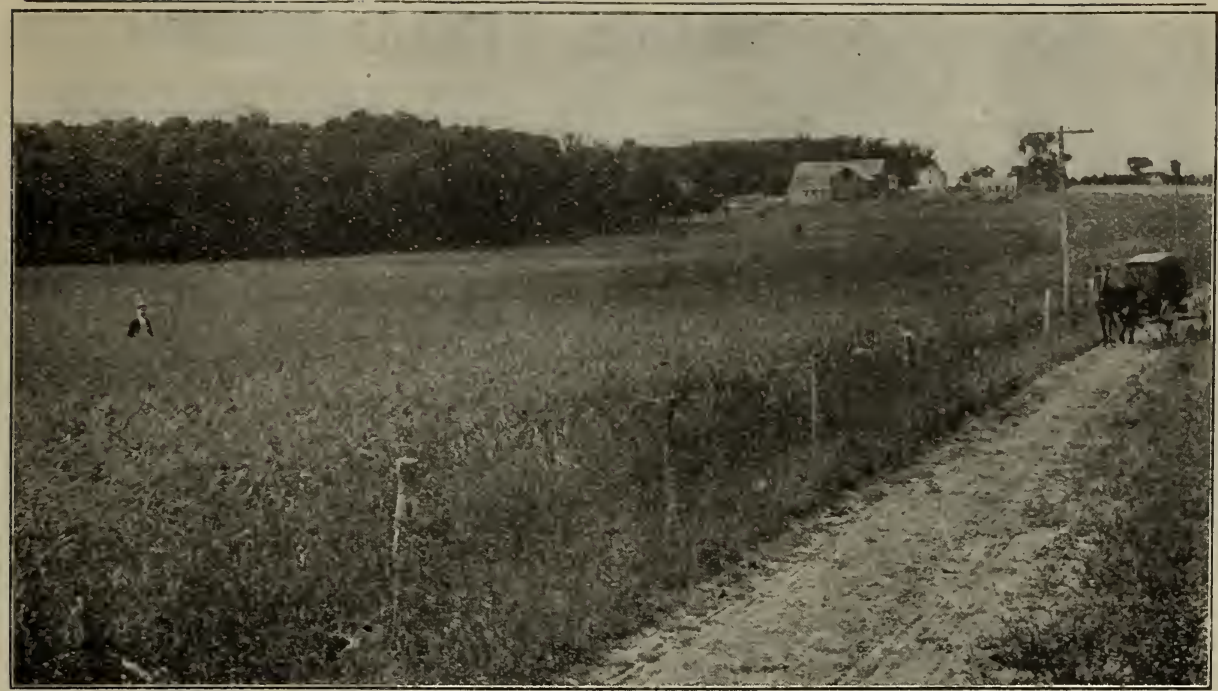

Field of Macaroni Wheat on Farm of L. T. Williams, Clinton, Wis.

\section{DURUM WHEAT (Macaroni).}

\section{KUBANKA NO. 5639.}

Durum Wheat is the best for making bread, declares M. A. Carleton, cerealist of the United States Department of Agriculture at Washington. He also says that there has been more dealing in this cereal at Duluth during the past year than in any other kind of wheat. Prof. Carleton says further: "Every conceivable test has been given Durum flour, and it has been demonstrated to be the equal, and superior in some respects to the usual run of flour on the market."

The entire crop of Durum Wheat last year was not less than $60,000,000$ bushels, and in fact this new wheat is fast taking the place of the old standard varieties of bread wheat all over the northwest. It yields more, grades higher, and is specially adapted to resist dry weather. It succeeds where other wheat cannot be grown at all. It is a spring wheat, and should be treated just like any other spring wheat.

Kubanka is the best of all the varieties of Durum Wheat, and No, 5639, as sent out from the South Dakota Ex. Station, has done the best of the different strains of Kubanka. Our stock is the genuine No. 5639, grown from seed sent nut by Prof. Shepard. It is Minnesota grown.

Prices: 1/2 pk., $30 \mathrm{c} ;$ pk., $50 \mathrm{c} ; \mathrm{bu}$. $(60 \mathrm{lbs}$.), $\$ 1.50 ; 2$ to 10 bus. at $\$ 1.30 ; 10$ bus. or over at $\$ 1.20$.

(Wheat prices include regular grain bags. Special prices for large quantities. Samples free.)

MINNESOTA NO. 169 WHEAT.

Pure Seed from Dean Liggett's Farm.

A new spring wheat of wonderful value. Distributed by the Minn. Ex. Station in 1902. It is an Improved Blue Stem or Velvet Chaff. The average yield of No. 169 for a term of 8 years at the Minn. Ex. Station was 27.4 bus. per acre, and of its parent, Blue Stem, 23.2. This was a net gain of 4.2 bus., or 18 per cent. 89 farmers throughout the state compared the new wheat with other wheat. and their trials averaged 3.3 bus. more per acre for the No. 169.

WVe are fortunate this year in being able to offer our customers seed of this new wheat grown on the farm of Col. Wm. M. Liggett, Dean and Director of the Minn. State Agl. College. He says of it: "There is no question about the wheat being pure and genuine.

Prices (Col. Liggett's pure No. 169): 1/2 pk., $30 \mathrm{c}$; pk., $50 \mathrm{c}$; bu., $\$ 1.75 ; 2$ to 10 bus. at $\$ 1.50 ; 10$ bus. or over at $\$ 1.35$.

\section{PEDIGREE BLUE STEM WHEAT.}

Blue Stem is a leading spring wheat throughont the northwest. The stock we offer is from a large grower in South Dakota, who assures us that the wheat is of his own growing and strictly pure pedigreed Blue Stem.

Prices: Pk., 50c; bu., $\$ 1.50 ; 2$ to 10 bus. at $\$ 1.35 ; 10$ bus. or over at $\$ 1.25$.

\section{TURKISH RED WINTER WHEAT.}

\section{The hardiest and most profitable rariety of} winter wheat. We are not in a wheat country, but many of our farmers here are making money growing this wheat. They get from 30 to 40 bushels per acre almost every year of splendid, bricht, plump wheat. TWe have pure seed.

Prices: Pk., 40c; bu., $\$ 1.25 ; 2$ bus. at $\$ 1.15$.

(Write for special prices and samples when you are rearly to sow next fall.)

CHICKEN FEED WHEAT. See page 85 .

\section{MAMMOTH SPRING RYE.}

Invaluable as a catch crop. Can be sown later than other spring grain. Does not grow quite as large straw as winter rye, but usually vields full as well. The seed we offer is home grown and can be relied upon.

Prices: Pk., 40c; bu. (56 lbs.), \$1.20; 2 bus. or over at $\$ 1.10$.

\section{WINTER RYE.}

New Petkus. A new variety that outyielded everything else here last seasun. Our growers are very enthusiastic over it. It has longer heads and a larger kernel than any other rye we have ever seen.

Prices: 1/2 pk., 30c; pk., 50c; bu., \$1.50; 2 bus. or over at $\$ 1.25$. (Special prices in quantity. Write us next fall.)

Olds' Improved White. A superior rariety originated right here. A cross of the large Iowa White with the common dark-colored rye, comlbining the size and color of the former with the stiffness of straw and hardiness of the latter.

Prices: Pk., $40 \mathrm{c}$; bu., $\$ 1.20 ; 2$ bus. at $\$ 1.10$.

\section{PRIMOST FLAX (Minn. No. 25)}

A new pure-bred variety of flax recently distributed by the Minn. Ex. Station. The arerage yield per acre as reported in 1905 by 48 farmers throughout the state was 15 bushels, as compared with 11.9 bushels, the average for common flax under the same conditions, a gain of $26 \%$ in favor of Primost. Our stock of seed comes direct from Cnl. Liggett's farm.

Prices: $1 / 2$ pk., 50c; pk., 75c; bu. (56 lbs.), $\$ 2.50$.

(We are always glad to quote sperial prices on large orders for seed grain of all kinds, and glar to send samples. "See our Free Sample Collection, page 8 .) 


\section{MISCELLANEOUS FIELD SEEDS.}

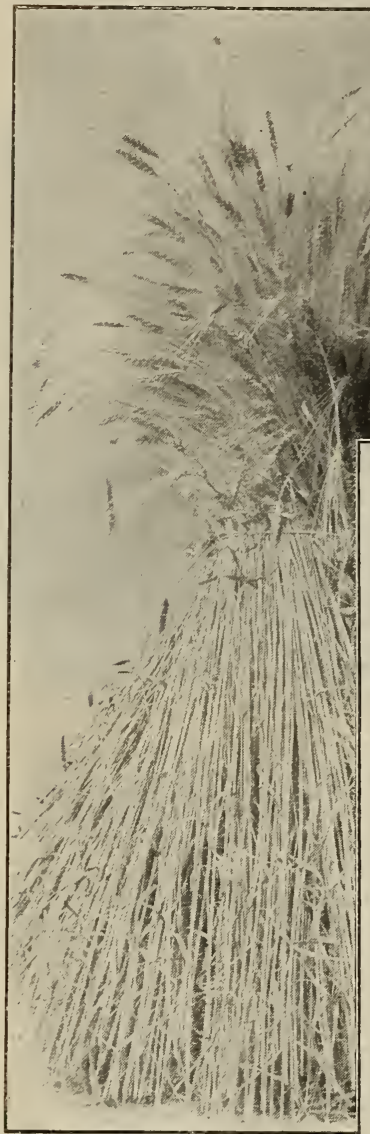

Sheaf of Speltz.

\section{SPELTZ or EMMER. THE WONDERFUL NEW RUSSIAN GRAIN.}

The illustration at the left is an exact representation of a sheaf of speltz. The lead of wheat used in most catalogues for a spelt. head is no more like it than a Holstein is like a Percheron. Speltz looks like barley ratlier than wheat.

It can hardly be recommended too highly. Every farnier in the west ought to sow some. It makes a splendid feed and lots of it. Witl our growers here it averages over one-third more bushels per acre than barley, and we are right in a barley country too. The farmers and stockmen here are all talking alout raising speltz next year. Note the following points about speltz. They are all facts. We can vouch for them personally. We have grown speltz seven year's, and know whereof we speak.

First. It is perfectly hardy and can be grown successfully anywhere. Second. It yields more bushels per acre than either oats or barley. Third. It is specially adapted to dry regions and to localities that are subject to hot, dry summers, as it withstands drought where barley fails entirely.

Fourth. It has such a very stiff straw that it stands up when both oats and barley lodge. In fact, the straw is about as stiff as rye straw.

Fifth. It makes a well-balanced feed for horses, cattle or hogs, as the large hull gives it the lightness of oats, while the double kernel furnishes a rich nieal much like ground rye feed. Prof. Wil. son, of the South Dakota Experiment Station, in a careful experiment with feeding calves, found for pound.

Sixth. It is especially fine as a nurse crop, as it never falls down and smothers the new seeding. Seventh. It is not affected by rust or smut. We never have seen a particle of smut in speltz.

Eighth. No special machinery is required for sowing, harvesting or threshing, different from other grain. Sow 2 to $2 \frac{1}{2}$ bushels per acre and treat in erery way the same as oats or barley. Ninth. The U. S. Dept. of Agriculture recom mends it very highly for stock feed. Thousands of farmers in the west and northwest are now raising speltz for feeding their horses, cattle and

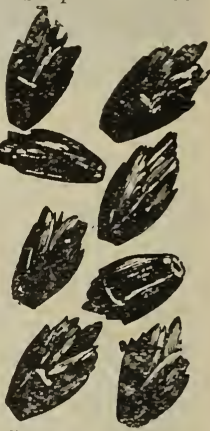

Speltz Kernels. all other stock. We are long on speltz again this year. Our prices are way down, hut write for special quotations if a large quantity is needed. Stock is colored some, but will grow all right

Prices: 1/2 rk., 20c; kk., 30c; bu. (40 lbs.), 80c; 2 to 10 bus, at $65 \mathrm{c} ; 10$ to 50 bus. at $60 \mathrm{c}$.

\section{DWARF ESSEX RAPE. Greatest of All Forage Plants.}

Probably no plant has ever jumped into favor so quickly with farmers everywhere as Dwarf Essex Rape. It is grown from the Atlantic to the Pacific, and although 5 pounds of seed is en:ugh for an acre, it requires hundreds and even thousands of tons of seed to supply the farmers of America. It is the ideal for sheep pasture, and is also now sown largely for hogs and cattle.

Dwarf Essex Rape is an annual, closely resembling in leaf and stalk the rutabaga, but it grows taller and more spreading. A good crop will furnish at least 12 tons of green feed rer acre, and its nutritive value is nearly twice that of clover. It may be sown in the fullowing ways:

1. In early spring for sheep and hog pasture.

2. With spring grain, 2 pounds per acre, to provide sheep pasture after harrest. In this case it is better not to sow the rape until after the grain is about up. 3. With oats and clover seed for pasture and to get a catch of clover.

4. Alone in June or July, on newly plowed land.

5 . With corn just before the last cultivation.

6. Along with rye, in August or September, for late pasture. $\Lambda$ word about the seed. We buy in car lots and handle only the best and purest Dwirt Essex, entirely free from bird rape, mustard or anything of that sort. The Dwarf Essex is the only desirable variety. Some seedsmen give it other names. such as Victoria, English, etc., simply to sell it. It is all imported, as the Rape is higher than usual this year, owing to short crop.

Prices: Lb. 15c; 5 lbs. $50 \mathrm{c}$ 10 lbs., 90c; 25 lbs., $\$ 1.75 ; 100$ lbs., $\$ 6.00 ; 500$ lbs. at $\$ 5.50$.

(Add $10 \mathrm{c}$ per $1 \mathrm{~b}$. if to go by mail.)

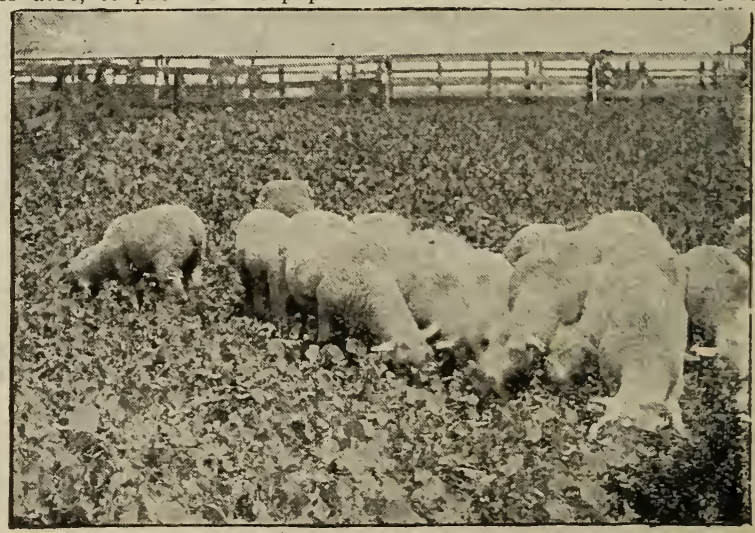

Best and Cheapest Pasture for Sheep. 


\section{SOY BEANS.}

Soy Beans are coming more and more into faror with lead. ing farmers and dairymen all through the northern states. They have a double value. First, they contain a very large amount of protein and are great for feed, both as a green forage plant and as dry beans; and, second, they are, like clover, nitrogen gatherers and enrich the soil wherever grown. Prof. Moore says: "As a forage, their use as a soiling crop is becoming recognized by stockmen and dairynen, as they withstand the drought exceptionally well and will give a good cutting of green forage at the time when other feeds are shriveled and wilted.' Feeding esperiments carried on at the IVis. Station have established the great value of soy

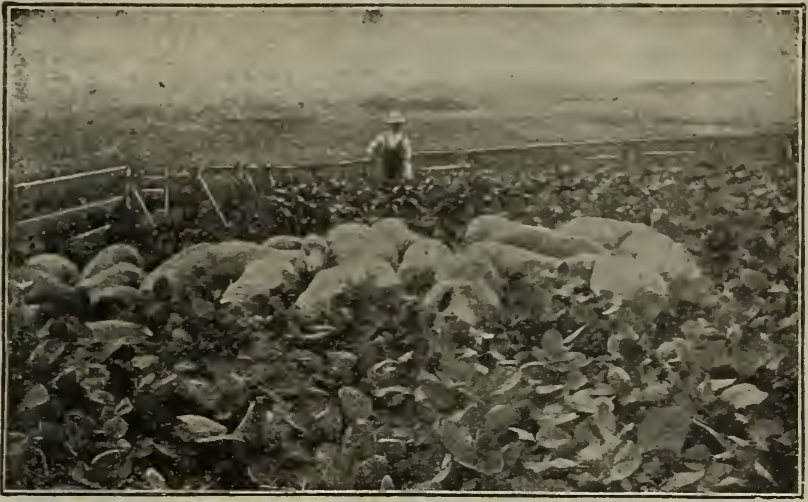

Soy Beans as Pasture.

bean meal for both pigs and soy beans per acre it will be a profitable feed to balance a corn ration for pigs. As high as 50 bushels per acre have been grown at the Wisconsin Station farm.

The Culture is not difficult. Sow just after corn planting, when the ground is warm, in drills 30 inches apart and 3 or 4 inches apart in the drill. From one to two pecks will seed an acre. When desired for hay, cut when the pods are partly dereloped. Soy beans mixed with corn make splendid silage. Every man who has a silo, try them. We offer seed of 3 leading early varieties, and our seed is all Wisconsin grown.

Prices, any variety, by mail: Pkt., 5c; pt., 20c; qt., 35c. By freight: Qt., 20c; 1/2 pk., 50c; pk., $90 \mathrm{c} ;$ bu. (60 Ibs.), $\$ 3.00$. (Special prices for larger quantities.)

EARLY BLACK. A very distinct jet black rariety recently introduced. It originated with Mr. E. E. Erans, the Sor Bean expert of northern Michigan. He says of it: "I consider it by all odds the best for the north yet introduced. It is sure to ripen in the northerm states."

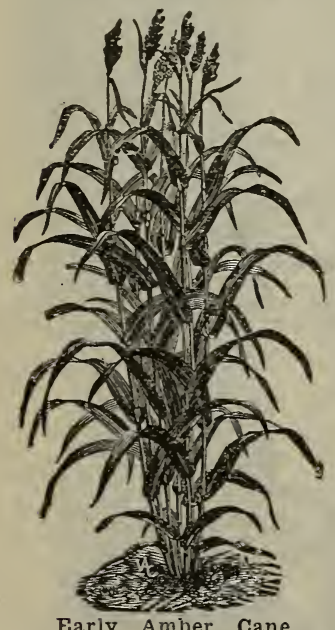

ITO SAN. A small, yellow bean with brown eyes. 'The best soy for hay and soiling and one of the heaviest seed producers. The variety niost largely grown thus far.

MEDIUM EARLY GREEN. Best for soiling and ensilage. A little larger than Ito San, but no later to speak of. Grows 3 to 5 feet high, with numerous branches. Can be grown with corn and harrested at the same time for the silo. Plant four parts of corn to one of soy beans, with ordinary corn planter.

\section{EARLY AMBER CANE (SORGHUM),}

Most Valuable for Dairy Cows.

The leading dairy farmers of the Northwest generally regard Sugar Cane or Sorghum as the best of all fodder plants today for their purpose. It is only recently, howerer, that it has come into general use. It can be easily grown on any good corn ground, is sweet and tender and greedily eaten by cattle, horses and hogs. It yields immense crops of fodder, as high as 100 tons of green feed being claimed from one acre. It may also be used for pastures. Sow any tine from May 15 to July 15,12 to 15 lbs. per acre in rows, and cultivate the same as corn. Or if sown broadcast, use 50 lbs. per acre. The Early Amber is the best variety and the most used. We hare provided a very large

Early Amber Cane. tock of choice seed for our cus-

Frices: $1 \mathrm{lb} ., 10 \mathrm{c}$; $10 \mathrm{lbs} ., 40 \mathrm{c} ; 100 \mathrm{lbs}$, $\$ 2.25$. (Add $10 \mathrm{c}$ per lb. if to go by mail. Special priecs in quantity.)

\section{WHITE KAFFIR CORN.}

\section{Yields Great Crops Everywhere.}

Largels grown in the South, and now coming into favor with vorthern farmers. It is a variety of sorghum cultivated in the South for both forage and grain. It grows 5 or 6 feet high, with a straight, upright growth and numerous broad leares. stalks keep green and are brittle and juicy, not hardening up like other varieties of sorghum. It makes the best kind of fodder for cattle or horses, and is easily grown. The seed is splendid for poultry. Nerer any failure

Sow in rows $2 \frac{1 / 2}{2}$ to $3 \frac{1 / 2}{2}$ feet apart and cultivate the same as corn, but do not sow until the ground is thoroughly warm. Five to ten lbs. will seed an acre if sown in rows, or $1 / 2$ bushel if sown broadcast.

Prices: 1 lb., 10c; 1/2 pk., 25c; pk., $40 \mathrm{c}$; bu. (50 lbs.), $\$ 1.00$. (Add $10 \mathrm{c}$ per $\mathrm{lb}$. if to go by mail. Special low prices in quantity.)

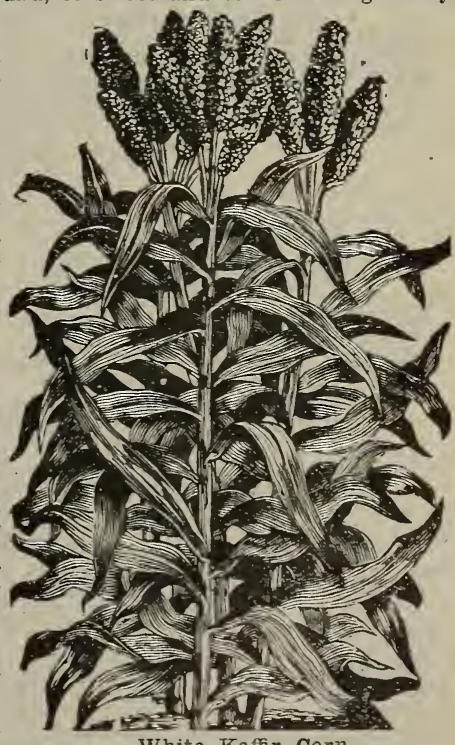

White Kaffir Corn.

(See Kaffir Corn for Poultry Food, page 85.) 


\section{FIELD PEAS.}

Farmers ought to grow more Field Peas. They are perfectly hardy all through the northern states and as easily grown as grain. They make fine pasturage for cattle or hogs, or they may be cut as hay when green or allowed to ripen and run through a threshing machine. Moreover, like all leguminous plants, they furnish the nitrogen so much needed in all soils. The U. S. Dept. of $\Lambda$ griculture says: "Peas could be made to bring more nitrogen to the soils of this country every year than is now purchased annually by the farmers at the cost of millions of dollars." Sow 2 bus. per acre broadcast, or better yet, sow with oats, 1 to $1 / 2$ bus. of each

WHIE ENA. The best known variety and the one usually sown. Our White Canadas this year are as fine as ever offered by any one and prices are low. Write for special prices in large quantity. Prices: Pk., 50c; bu., $\$ 1.50 ; 2$ bus. or over at 1.35. (All prices include bags.)

GREEN CANADA. Like White Canada except in Prices, same as for White Canada.

SCOTGH BLUE. Famous for soup.

Prices: Pk., $50 c ;$ bu., $\$ 1.65 ; 2$ bus. or over at $\$ 1.50$.

BLACK-EYED MARROWFAT. Vines are large and strong, 5 feet high, with large, well-filled pods of large peas.

Prices: Pk., 50c; bu., $\$ 1.80 ; 2$ bus. or over at $\$ 1.65$

WHITE MARROWFAT.' Similar to Black-Eyed

Marrowfat. Prices, same.

(One quart any variety Field Peas, by mail, 25c; by freight, 10c.)
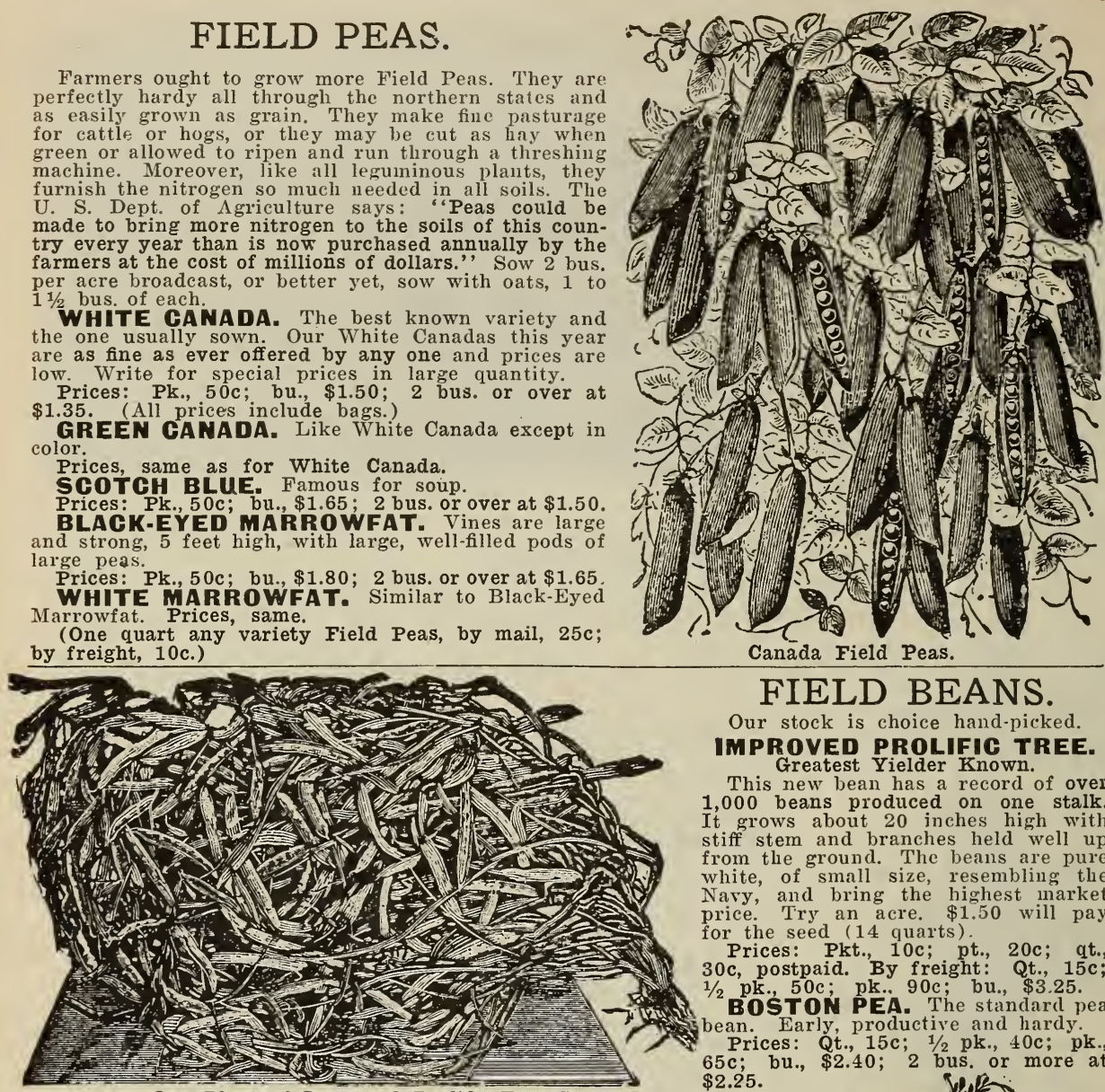

Canàda Field Peas.

FIELD BEANS.

Our stock is choice hand-picked.
IMPROVED PROLIFIC TREE.

Greatest Yielder Known.

This new bean has a record of over 1,000 beans produced on one stalk. It grows about 20 inches high with stiff stem and branches held well up from the ground. The beans are pure white, of small size, resembling the Nary, and bring the highest market price. Try an acre. $\$ 1.50$ will pay or the seed (14 quarts)

Prices: Pkt., 10c; pt., 20c; qt., $30 \mathrm{c}$, postpaid. By freight: Qt., $15 \mathrm{c}$; pk., 50c; pk.. 90c; bu., $\$ 3.25$. BOSTON PEA. The standard pea Prices: Qt., 15c; 1/2 pk., 40c; pk. $65 \mathrm{c} ;$ bu., $\$ 2.40 ; 2$ bus. or more at

One Plant of Improved Prolific Tree Bean.

CHOICE NAVY. Too well known to need describing. Prices, same as for Boston Pea.

RED KIDNEY. A large, handsome bean and quite a favorite Prices: Qt., 15c; 1/2 pk., 50c; pk., 75c; bu., $\$ 2.75$.

(Add 15 cents per quart to bean prices if to go by mail.)

\section{COW PEAS.}

Cow Peas are a standard crop all through the south, and of recent years are being grown with considerable success in the north. Like

Soy Beans, they should not be sown until the soil becomes warm

NEW ERA. An extra early variety, perhaps the best for the north. Pk., 60c; bu., $\$ 2.25$.

WHIPPOORWILL. A standard variety. Most largely grown. Prices, Southern grown: Pk., 60c; bu., \$2.25.

MIXED. A mixture of several leading varieties.

Prices, same as for Whippoorwill.

\section{SAND VETCH (VICIA VILLOSA).}

A most valuable leguminous plant. It belongs to the pea family, but the vines are longer and more leafy. It grows at a time of year when other plants have made their growth, and brings an immense amount of fertility to the soil, as well as making splendid pasture. Remains green all winter. Ten pounds will seed an acre.

Prices, by mail: Pkt., 5c; lb., 30c. By freight: Lb., 20c;

lbs., 75c; 10 lbs., \$1.25; 100 lbs., \$10.00.

MAMMOTH RUSSIAN SUNFLOWER. A great food for

Prices, by mail: Pkt., 5c; pt., 15c; qt., 20c. By freight: Qt. $10 \mathrm{c} ;$ pk., $50 \mathrm{c} ; \mathrm{bu}$. (22 ibs.), $\$ 1.40 ; 100$ libs., $\$ 4.00$.

SPANISH PEANUT. The earliest variety and a great yielder. Pods small but very numerous. Profitable to grow for hogs.

Prices, by mail: Pkt., 5c; pt., 15c; qt., 25c. By freight: Qt.,

15c; pk., $75 \mathrm{c}$; bu. $(22$ lbs. $\$ 2.50$ ins. Resemble the almond in

Whetness and flavor. Very prolific and easily grown anywhere.

Prices: Pkt., 5c; 1/4 Ib., 15c; Ib., 40c; 3 lbs., 90c, postpaid.

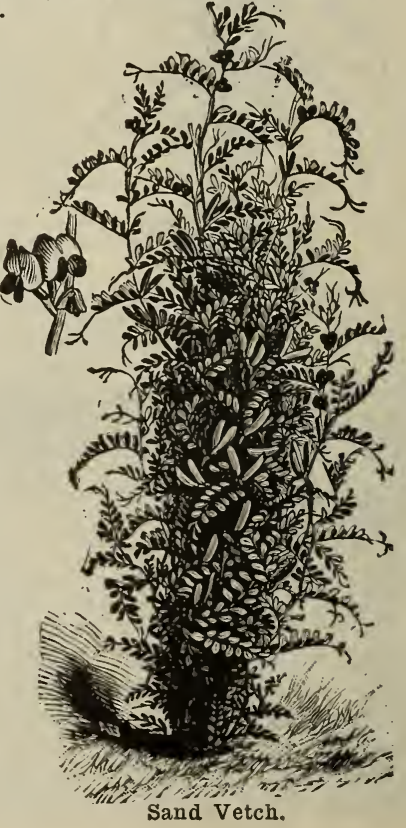




\section{JAPANESE MILLET. \\ (BILlion DOLlaR GRASS.)}

Japanese Millet is one of the most remarkable forage plants we have: remarkable for its marvelous, luxuriant growth, often growing six feet tall; remarkable for the immense amount of hay it produces from each acre, and remarkable for its feeding value. It is adapted to all sections: does especially well on low ground; makes more hay than German or any other kind of millet, and requires less seed per acre; produces a crop in a very short time is relished as hay by stock of all kinds, or, if allowed to ripen, will yield about as many bushels per acre as oats. The seed can be used for feed, and is specially fine for poultry.

Sow in May for best results, 15 to 20 pounds per acre. If desired for hay, cut just before it heads out. Or it can be left to ripen and then threshed the same as timothy. Our halftone illustration, showing heads of Japanese Millet over six inches long, as picked from the field of one of our growers here, gives some idea of the immense seed production-a handful of seed from every head.

Prices: $1 / 2$ pk., 35c; pk., 50c; bu. (40 lbs.), $\$ 1.50$; 2 to 10 bus. at $\$ 1.25 ; 10$ bus. or over at $\$ 1.15$.

GERMAN MILLET. Grows larger than Common Mil let, and is much more productive. Our seed is grown in the southwest, and is brighter and finer looking than northern grown. It will yield more, too. Here is a case where southern-grown seed is better than northern. In

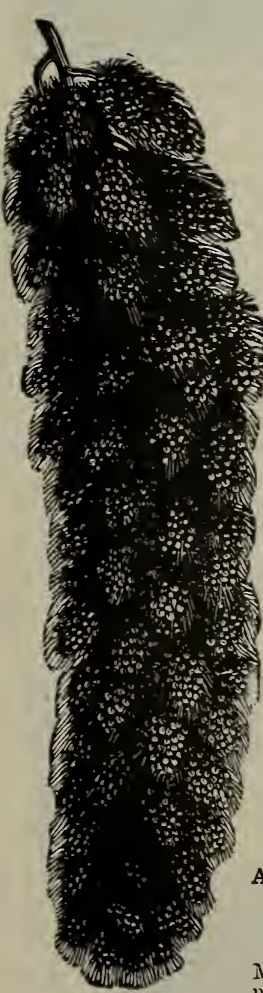

fact, German Millet becomes Common Millet, losing its plumpness grown in the north. Sow $1 / 2$ bushel to 3 pecks per acre.

Prices: Pk., 35c; bu. (50 lbs.) $\$ 1.10 ; 2$ bus. or over at $\$ 1.00$. (Prices subject to change. Write for samples and special prices when ready to buy.)

COMMON MILLET. Pres ent prices same as for German.

HUNGARIAN. Preferred by some to German Millet, as it is about a week earlier. Does not grow as large, but makes finer hay.

Prices: Choice seed, pk., 35c; bu. (48 lbs.), $\$ 1.20 ; 2$ bus. or over at $\$ 1.10$.

SIBERIAN MILLET. A new rariety from Russia, and earlier than either German Millet or Hungarian. The South Dakota Ex. Station says: "The most promising variety yet tested."

Prices: Choice grade, pk., 35c; bu. (50 lbs.), $\$ 1.20 ; 2$ bus. or over â $\$ 1.10$.

EARLY FORTUNE MILLET. Another very promising new variety, 2 weeks earlier than German Millet. Astonishing yields are reported. Seed large in size and very beautiful.

Prices: Pk., 40c; bu. (50 lbs.), $\$ 1.30 ; 2$ bus. or over at $\$ 1.20$.

HOG OR BROOM CORN MILET. Also called Dakota Millet. Makes inferior hay, unless cut very young, but yields enormous quantities of seed as high as 60 or 70 bushels per acre. This seed is fine for poultry, hogs and other stock. Prices, same as for Early Fortune Millet.

PEARL MILLET. Quite different from all other millets. Grows rery tall and produces an immense amount of fodder. Will not mature seed in the north.

Prices: $5 \mathrm{lbs}$., $50 \mathrm{c} ; 10 \mathrm{lbs}$. (enough for one acre), 90c; $100 \mathrm{lbs}$., $\$ 6.50$.

(One pound, any one of the above varieties, by mail, $25 \mathrm{c}$; by freight, 15c. Sample packets free.)

\section{PENCILARIA.}

Ahead of Everything else in Amount of Fodder Produced.

Pencilaria is a species of Pearl Millet, although it looks and grows more like cane or kaffir corn.

German Millet.

A yield of 95 tons per acre of green fodder is claimed, and 16 tons of good in one season. Grows to can be cut four or fire times left long enough, but should be cut when only half that height, as it is more tender. Superior in quality to corn fodder, kaffir corn or any similar plant. Sow at cornplanting time, in rows 2 or 3 feet apart, and 3 or 4 seeds to each foot of row. One pound will seed an acre. Cover very shallow, only $1 / 4$ to $1 / 2$ inch deep. Cultivate same as corn. The seed we offer is from the original introducers.

Prices: Pkt., 5c; 1/4 lb., 15c; lb., 35c, postpaid. By freight: Lb., $25 \mathrm{c} ; 5 \mathrm{lbs}$. at $20 \mathrm{c} ; 25 \mathrm{lbs}$. at $15 \mathrm{c}$. 


\section{CLOVERS AND GRASS SEEDS.}

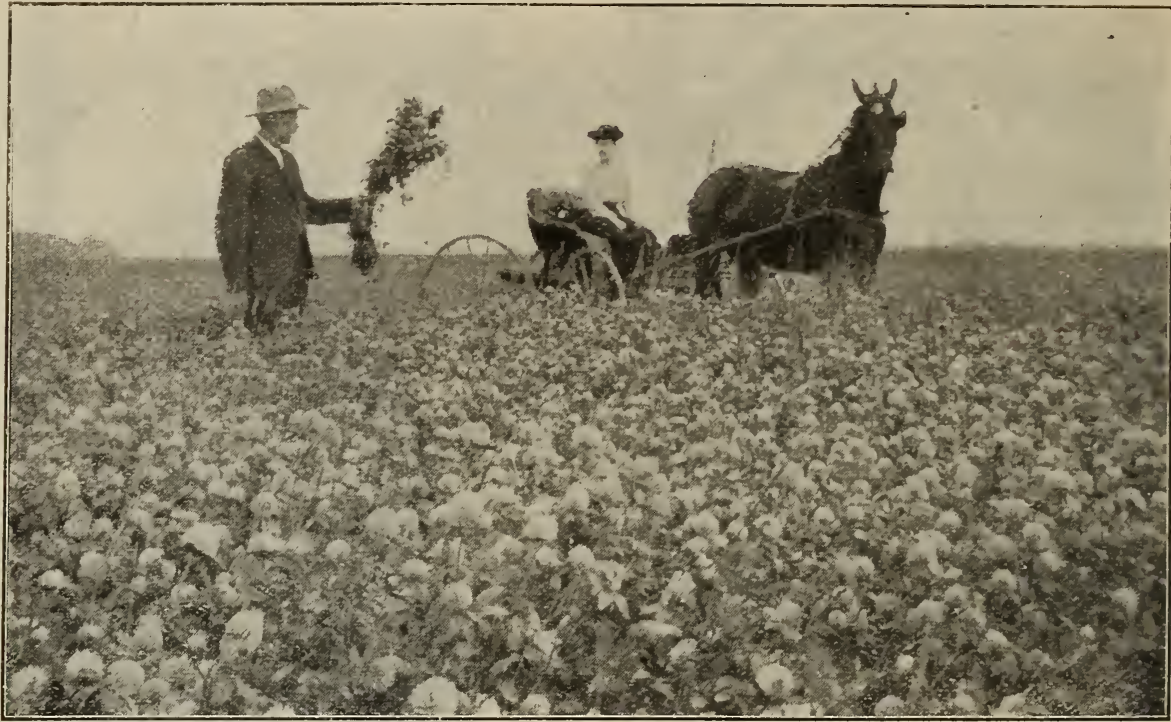

A Fine Field of Medium Red Clover.-Grown by J. W. Scott at Gilby, Grand Forks Co., N. Dak.

\section{OLDS' CHOICE CLOVER SEED.}

\section{GET OUR PRICES AND SAMPLES BEFORE BUYING.}

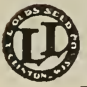

We make a specialty of choice Clover Seed, buying and seliing in large quantities. TTiseonsin is a great state for Clover Seed, and the crop the past season was better than in most states. The clover crop generally throughout the country was a short one, and as hardly any seed was carried over, it looks as if prices would be considerably ligher than they are now. We have stocked up heavily, anticipating an unusually large demand, and at the time of cleaned. Our cleaning machinery is of the very best. It always pays to get the cleanest seed possible when it comes to clover.

Prices of Clover Seed can never be fixed definitely to last throughout the season. Write us wlien you are ready to buy, and we will submit samples and quote lowest net prices at that date. The sample method is the most satisfactory way to buy clover and timothy. If desired, however, we will fill orders to the best of our ability, sending as much seed as the money will pay for of the grade we think will be most satisfactory. Our old Gold Brand represents the best, and small orders, less than one bushel, are always filled with this grade. Bushel prices do not include bags. Add $18 \mathrm{c}$ for each bag required.

MEDHUM RED GLOVER. This is the standard common red clover, and the best for hay Be sure to get our samples and prices before buring elsewhere. Considering quality we think you will find our prices the lowest of any. Remember, "The best is the cheapest" when it comes to clover seed.

Prices-OLD.GOLD BRAND, by mail: Lb., 30c; 3 lbs., 80c. By freight, present price: Pk. $\$ 2.25$; per bu. (60 lbs.), $\$ 8.50$. Other grades, $\$ 8.00$ and $\$ 8.25$ per bu. Bags extra, $18 \mathrm{c}$ each.

MAMMTH RED CLOVER. Resen.bles Medium, but larger and coarser. Best for pasture and as a fertilizer, but not usually considered as desirable for hay, because too large.

Prices, same as Niedium for similar grades.

ALSYKE CLOVER. Finer and more leafy than Red Clover, but grows to a good height and makes a heary yield of hay. Also fine for pasture. Alsyke is the only clover that will produce a root cill out on wet land. The seed is very small, and goes fully twice as far as otler clover. Five or six pounds will seed an acre. Many farmers mix a little Alsyke with all the Medium they sow, a decidedly good idea. We have some splendid Alsyke to offer this year, and prices are considerably lower than for Red Clover.

Prices-Old Gold Brand, by mail: Lb., 30c; 3 lbs., 80c. By freight, present price: Pk., $\$ 2.15$; per bu., $\$ 8.00$. Other grades, $\$ 7.50$ and $\$ 7.75$ per bu.

WHITE DUTCH GLOVER. Desirable for pasture mixtures Also fine for lawns, The hardiest of all clovers. Its low creeping habit and tenacity of root make it valuable for establishing a new turf. Five to $7 \mathrm{lbs}$. will seed an acre.

Prices-Old Gold Brand, by mail: Lb., 35c; 3 lbs., 90c. By freight: Lb., 25c; 5 lbs., $\$ 1.00 ;$ pk., $\$ 2.25 ;$ bu., $\$ 8.50$. Second grade, $\$ 7.50$ per bu.

CRIMSON GLOVER (see illustration). Also called Giant Incarnate. This is an annual clover largely used in the east and south, and now being tried somewhat in the north. Sow in April or May, 15 los, per acre, or it may be sown in corn at the time of the last cultivation in July. We have but one grade, the best.

Prices-by mail: Lb., 25c; 3 lbs., 65c. By freight: Lb., $15 \mathrm{c}$; pk., $\$ 1.50$; bu. (present price), $\$ 5.00$.

OLDS" CLOVER MIXTURE.

A mixture of Medium, Mammoth, Alsyke and White stand. We recommend this for sowing with
Permanent Pasture Mixture (see next page).

Prices-by freight: Lb., 20c; pk., \$2.25; bu. (60 lbs.), \$8.25.

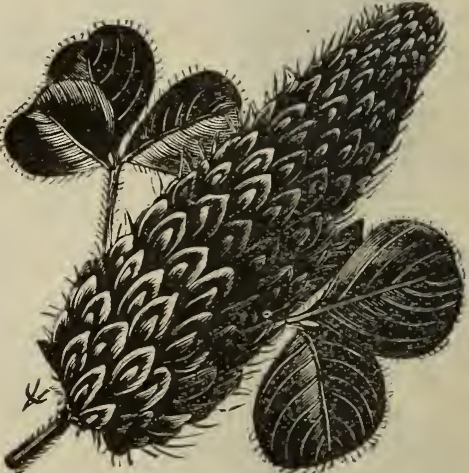

Crimson Clover. 


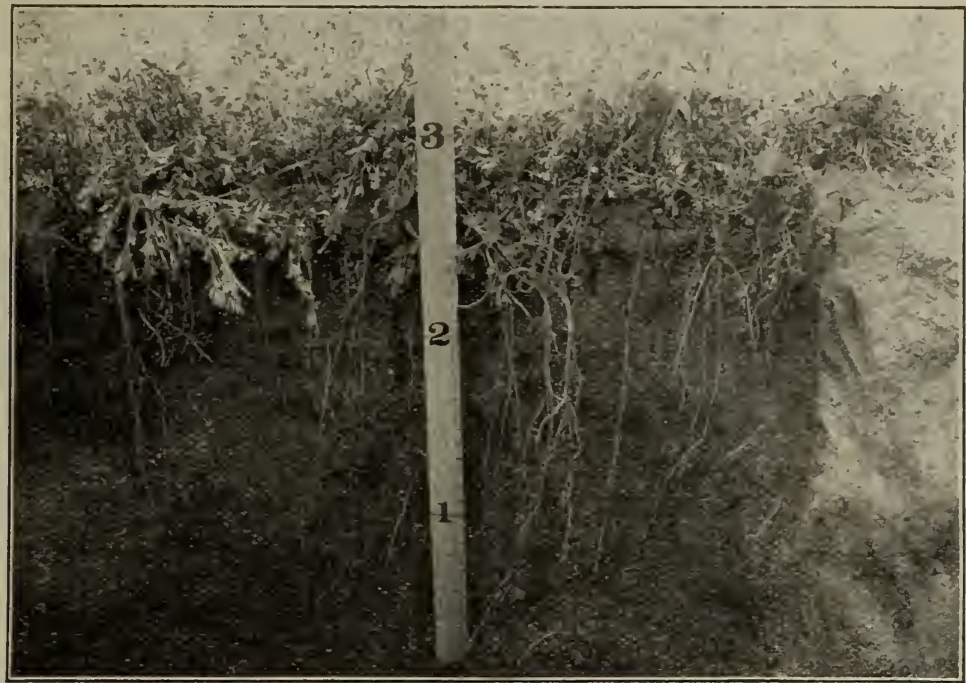

Showing Root Development of Yearling Alfalfa Plants. See page 8.

\section{BROME GRASS (Bromus Inermis).}

Most Valuable New Grass Introduced in Recent Fears.

Bromus adapts itself to nearly all conditions of soil and climate, and yields enormous quautities of hay and makes abundant pasture. It defies drought, and is not affected by frost. Splendid fur

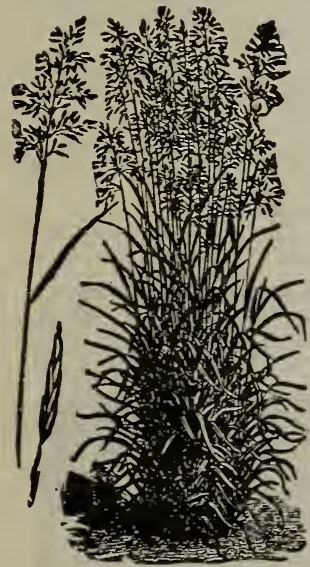

Bromus Inermis. permanent grass.

The Culture is not difficult. Sow broadcast on a still day early in spring on well-prepared ground, harrowing in the seed. Sow grain about one bushel per acre only, of barley or vats for a mirse erop.

The grass is inconspicuous and tender the first year. Do not plow it up, thinking the stand is insufficient. IIany fine fields of Brone Grass have been lost in this way. The second year, a crop of seed and a crop of hay may be secured. When the seed is ripe, cut high with a binder, shock and thresh same as oats. In about two weeks, cut the hay with a mower. After the first year, Brome Grass will hold its own and is not easily killed except by plowing.

Prices: Pedigree Seed (very choice): By mail, lb., 40c; $3 \mathrm{lbs} ., \$ 1.00$. By freight, lb., 30c; 10 lbs., $\$ 2.25 ; 100$ lbs., $\$ 18.00$. (Bromus prices

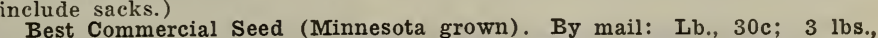
75c. By freight: Lb., $20 \mathrm{c} ; 10 \mathrm{lbs}$., $\$ 1.15 ;$ per $100 \mathrm{lbs}$., $\$ 9.50$.

(Our Pedigree Seed was grown by Prof. Jas. H. Shepard, of the South Dakota Agl. College, a Brome Grass specialist, and is guaranteed genuine and free from foul seed of any kind. Ten pounds of this seed is sufficient for an acre, while 20 to 30 of ordinary seed is generally recommended.)

\section{TIMOTHY.}

This is the most valuable of all grasses for hay, especially here in the nortl. We have a large stock of choice seed on hand, all home grown. We know what farmers grew it, and know it is free from foul seed.

Prices-First grade, by mail: Lb, 20c; 3 lbs., 50c. By freight, present price: Pk. $60 \mathrm{c}$; per bu, ( $45 \mathrm{lbs})$, $\$ 2.15$. Other grades: Per bu., $\$ 1.90$ and $\$ 2.00$. Bags extra at $18 \mathrm{c}$.

(We are able to make low prices on Timothy because we buy all our seed direct from the men who grew it. Write us for lowest quotations with samples, when ready to buy.)

\section{OLDS' PERMANENT PASTURE MIXTURE.}

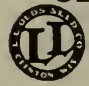
his is a mixture of the best grasses for a permanent pasture, Red Top and Orchard Grass being the foundation. In many sections of the country, Timothy and Clover are sown exclusively. While Timothy is of itself an excellent grass, and Clover the basis of all successful farming, the fact that both of these, even under the most favorable conditions, have to be re-sown, leads us to look for something more permanent for pasture. Timothy and Clover are both affected by drought, while the grasses in our Perma. nent Mixture have been selected with a view to withstand soil and climatic conditions. Sow 25 pounds to the acre, and 10 pounds extra of our clover mixture if clover is wanted (see page 42), sowing the clover separately.

Prices-by freight: Lb., 15c; 10 lbs., \$1.30; 25 lbs., $\$ 3.00 ; 100$ lbs., $\$ 11.00$, sacks included." Sample free.

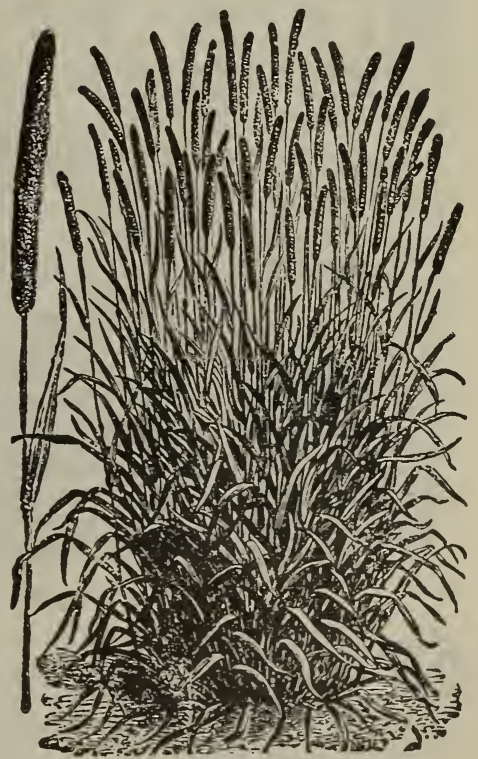

Timothy. 


\section{A SELECT LIST OF LIGHTER GRASSES.}

The following are the most valuable of the lighter grasses. We aim to handle only the best grades, and we believe all the seed we offer is pure and clean.

Prices quoted on this page include sacks but not postage. If wanted by mail, add 10 cents per pound. Ask for samples and special prices if large quantities are wanted.

ORCHARD GRASS. One of the most desirable grasses; withstands drought, will grow in the shade, and does well on poor land. Sow 3 bushels to the acre. Lb., 20c; bu. (14 lbs.), \$1.75; 100 lbs., \$10.00.
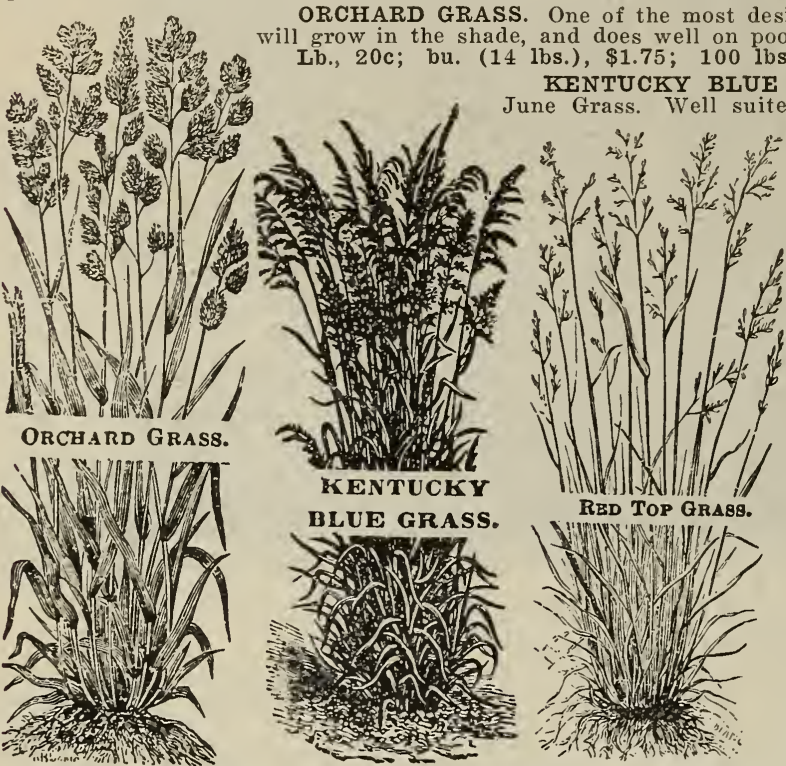

SWEET VERNAL. Useful to mix with other grasses on account of its early growth and agree able odor; fine for lawns.

Lb., 25c; 10 lbs., \$2.00.

able for low ground.

, $25 \mathrm{C}$;

Recommended for shor herbage. Should be in all sheep pasture mixtures.

Lb., 20c; bu. (12 lbs.), \$1.75.
BLUE GRASS.

RED TOP GRAss.

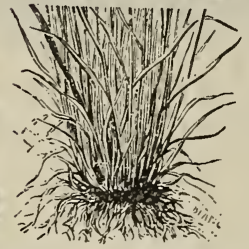
cre.
Tell suited for pasture, and a perfect lawn grass. Sow 2 to 3 bus to the acre. Lb., 2jc; 5 lbs., $\$ 1.00$; bu. (14 lbs.), $\$ 2.50 ; 100$ lbs., $\$ 14.50$. RED TOP. Also known as Herd Grass; well adapted to the for meadows and pastures. Sow 30 to 40 pounds to the acre. Lb., 15c; bu. (14 lbs.), $\$ 1.50$ 100 lbs., $\$ 8.50$.

FANCY RED TOP. Solid Seed. The same variety as the above, but chaff ; ligher priced, but reap in the end, as 3 pounds will equal ne bushel of ordinary IRed Top. Lb., 20c; bu. (42 lbs.), \$5.00; 100 lbs., $\$ 10.25$.

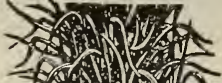

ENGLISH or PERENNIAL RYE GRASS. Used for pastures and lawns; succeeds well in the shade. Sow 2 bushels to the acre.

Lb., 15c; bu. (24 lbs.), $\$ 1.50$; 100 ibs., $\$ 5.00$.

ITALIAN RYE GRASS. Dis tinet from the preceding, being larger and stronger in growth. 100 lbs., $\$ 5.75$.

MEADOW FESCUE. Also known as English Blue Grass. Excellent for permanent pasturage, foliage tender and nutritious. Sow 2 bus. to the

Lb., 15c; bu. (24 lbs.), \$2.25; 100 lbs., $\$ 8.00$ TALL MEADOW OAT GRASS. For dry soils. Lb., 20c; 10 lbs., \$1.75.

(No trouble to ., Tend like to have our customers ask for samples when needing any amount of seed.)

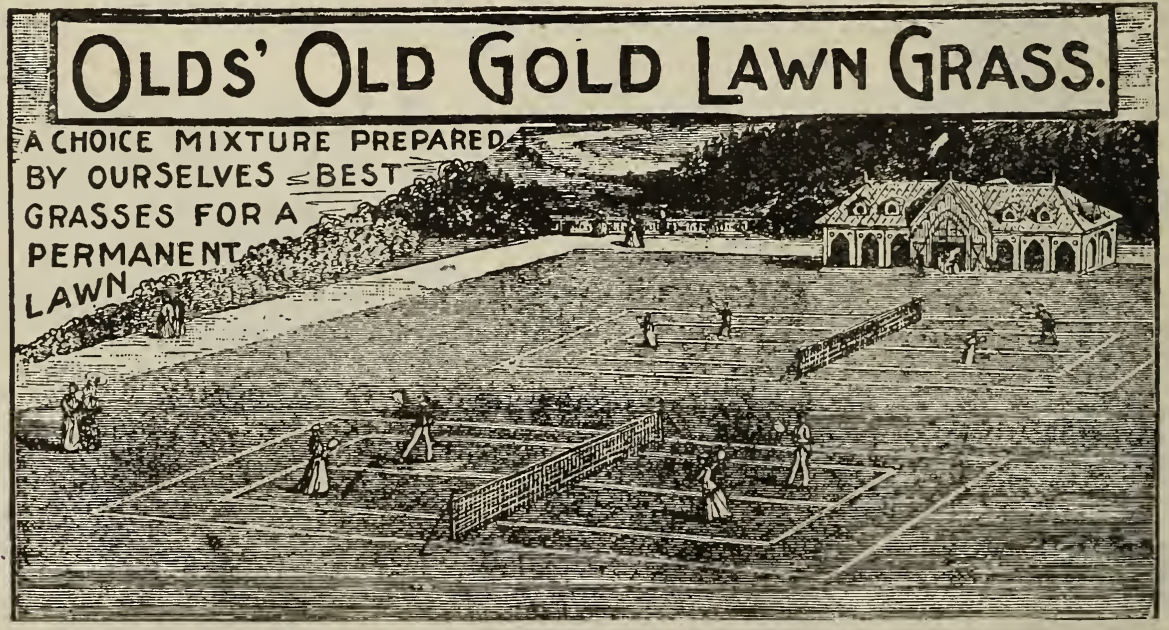

\section{OLD GOLD LAWN GRASS.}

(III) Nothing adds more to the attractiveness of the home than a nice, clean, well-kept, velrety lawn. Thousands of dollars are spent every year for sodding, which could be saved and better results obtained by sowing Choice Lawn Grass Seed. Our mixture contains the best grasses for a permanent lawn, Kentucky Blue Grass being used as the foundation. For making new lawns, sow from 3 to 5 bushels per acre; for a plot 15 by 20 , or 300 square feet, sow one pound of seed.

Lb., 25c; $1 / 2 \mathrm{pk}$., $50 \mathrm{c}$; pk., $90 \mathrm{c}$; bu. (20 lbs.), $\$ 3.25$. Add $10 \mathrm{c}$ per pound if to go by mail.

(White Dutch Clover, see page 42 , is splendid for lawns, but is best sown separately. We put no clover at all in our Lawn Grass Mixture. as it does not mix well with the lighter grasses.) 


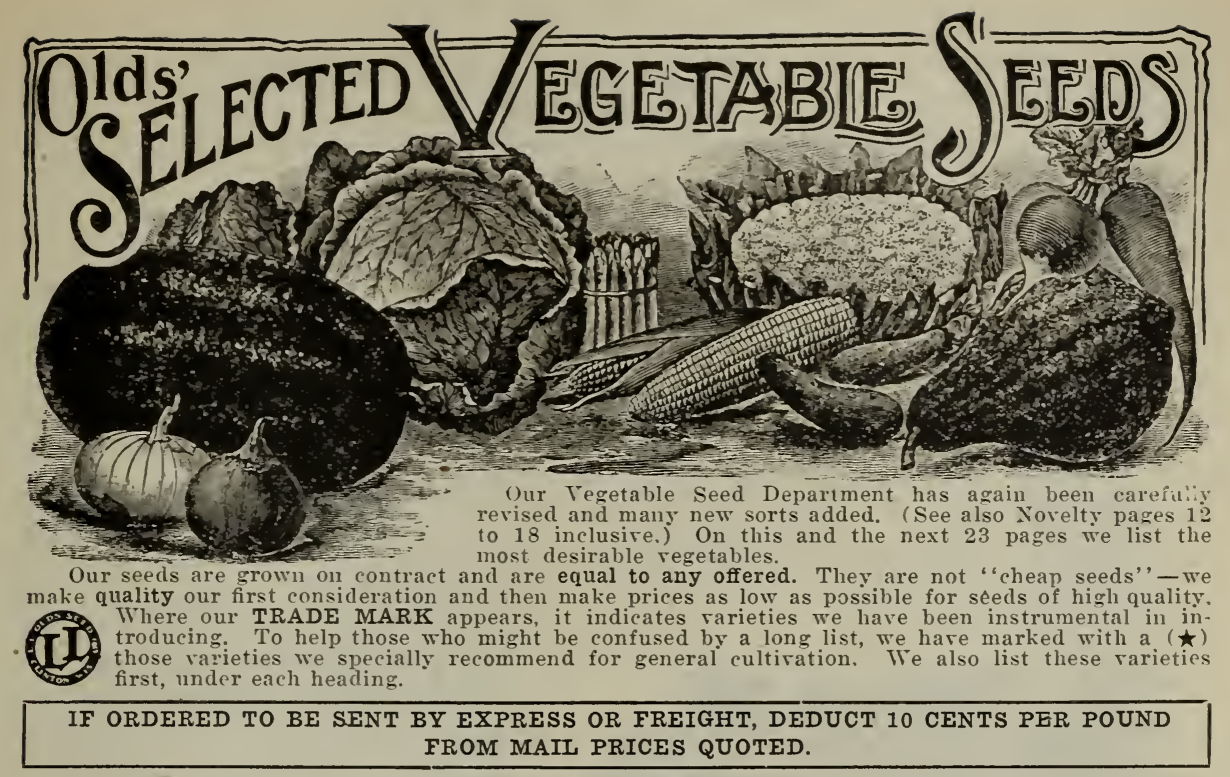

\section{DISCOUNTS.}

To Market Gardeners and those whose orders amount to ten dollars or more, we will make special prices. Send us your list before ordering.

CASH DISCOUNT. We allow the following discounts on all Garden Seed orders, excepting for packets and ounces, and for Beans, Peas and Onion Sets by the bushel and Onion Seed in 5-lb, lots:

5 per cent on all Garden Seed orders, excepting as abore, amounting to $\$ 3.00$

8 per cent on all Garden Seed orders, excepting as abore, amounting to from $\$ 3.00$ to $\$ 5.00$.

12 per cent on all Garden Seed orders, excepting as abore, amounting to from $\$ 5.00$ to $\$ 10.00$.

15 per cent on all Garden Seed orders, excepting as abore, amounting to $\$ 10.00$ or more.

On packets and ounces (excepting Collections), deduct 25 per cent (one-fourth) on orders amounting to $\$ 1.00$ or more. Please remember, howerer, the 25 per cent discount does not apply to Discount, and we invite comparison between our prices and those of any other reputable house.

\begin{tabular}{|c|}
\hline NORTHERN GROWN SEEDS \\
\hline \hline $18 \mathrm{C}$ TEANS \\
PENCIL POD WAX \\
\hline L. L. Olds Seed Company, Clinton, Wis. \\
\hline
\end{tabular}

\section{DO OUR SEEDS GROW?}

Our seeds are not allowed to go out on orders until the germination is prored by test. A record of each test is kept in our stock book. The stock letter is stamped on the face of each package, as shown in illustration (one of our seed bags, reduced in size). By reference to this stock letter, we can tell exactly what the germination is of any particular stock.

Order early. We want to receive as many orders as we can before our busy

Order by number. The number appears at the left of each rariety, and if used will expedite the filling of orders.

\section{ASPARAGUS}

The Asparagus bed furnishes the first green delicacy for the table in the spring. is unicersally popular, and requires but little care. Our packets each contain 1/1 oz. of seed and will plant 15 feet of drill; four to fire pounds, an acre. We recommend planting roots, however, rather than seed.

1. CONOVER'S COLOSSAL. The standard rariety. Two-year-old roots: 25,35 cts.: 100 , $\$ 1.15$, postpaid. By express or freight, not prepaid: 25,25 cts.; 100,65 cts.; 1,000, \$5.00. SEED: Pkt., 3 cts.; oz., 5 cts.; $1 / 4$ lb., 15 cts.; 1b., 45 cts., postpaid.

2. COLUMBIAN MAMMOTH WHITE. A new rariety, with white shoots that stay white. Rather more rigorous in growth and shoots larger than those of Conorer's Colossal. Two-year-old roots: Doz., 25 cts.; 25, 40 cts.; 100, $\$ 1.40$, postpaid. By express or freight not prepaid: 25,30 cts.; 100, 75 cts.; 1,000, \$6.00. SEED: Pkt., 5 cts.; oz., 10 cts.; 1/4 lb., 15 cts.; 1b., 50c, postpaid.

3. BARR'S MAMMOTH. Large and productire; grows twice as large as Conover's Colossal. Pkt., 5 cts.; Oz., 8 cts.; 1/4 lb., 15 cts.; lb., 50 cts., postpaid.

4. BONVALLET'S GIANT. This new Asparagus has prored to be in great demand: its flaror, size and whiteness recommend it ahead of any other. Pkt., 5 cts.; 0z., 10 cts.; 1/4 lb., 30 cts.; lb., $\$ 1.00$, postpaid.

We can furnish roots of Conover's Colossal and Columbian Mammoth White only-50 of a kind at the 100 rate; 500 at the 1.000 rate. Special prices on larger lots on application.

FLOWER SEEDS, BULBS and PLANTS-Pages 71 to 79 inclusive. 


\section{BEANS}

Our Packets each contain full 2 ounces and will plant from 15 to 20 feet of drill. One quart will plant 150 feet of drill; $1 \frac{1 / 2}{2}$ bushels, 1 acre. Of the many varieties of beans the following comprise the best. Our beans are Northem grown, thoroughly rogued and carefully hand-picked.

\section{VARIETIES WE SPEGIALLY REGOMMEND.}

All beans by the pint, half-peck and half-bushel will be sup plied at quart, peck and bushel rates, respectively.

Early Orders Solicited. Order by Number.

18. OLDS' PENCIL FOD WAX. The best early wax pod Bean

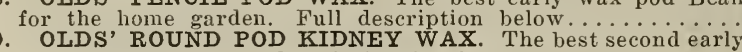
19.

21. BURPEE'S STRINGLESS GREEN POD. The best Bean 24. CURRIE'S RUST-PROOF WAX. The best Wax Bean for

Market Gardeners. Full description below

26. BURPEE'S BUSH LIMA. The best bush Lima Bean-no

14. Poles or stakes. Full description next page.

20. THE LONGFELLOW. See page 12

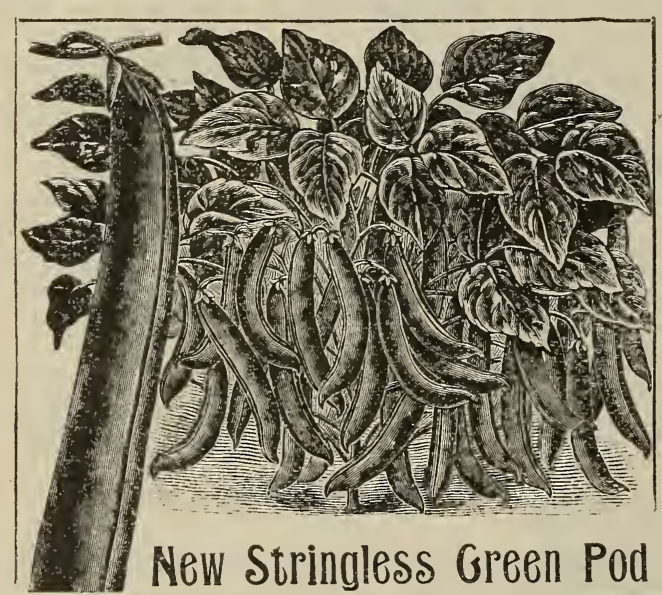

\begin{tabular}{|c|c|c|c|c|c|}
\hline \multicolumn{3}{|c|}{ By Mail, Postpaid } & \multicolumn{3}{|c|}{$\begin{array}{l}\text { By Frt. or Exp. } \\
\text { not prepaid. }\end{array}$} \\
\hline Pkt. & Pt. & Qt. & Qt. & Pk. & $\mathrm{Bu}$. \\
\hline$\$ 0.10$ & $\$ 0.20$ & $\$ 0.35$ & $\$ 0.20$ & $\$ 1.50$ & $\$ 5.50$ \\
\hline .10 & .25 & .40 & .25 & 1.75 & 6.00 \\
\hline .10 & .20 & .35 & .20 & 1.45 & 5.00 \\
\hline .05 & .20 & .35 & .20 & 1.25 & 4.00 \\
\hline .10 & .20 & .3 & .20 & 1.50 & 5.5 \\
\hline .1 & .20 & .35 & .20 & 1.50 & 5.00 \\
\hline .10 & .20 & .35 & .20 & 1.25 & 4.50 \\
\hline
\end{tabular}

\section{A NEW EXTRA EARLY.}

21. ^BURPEE'S STRINGLESS. If you want just one variety of beans, take this. We used to think the wax pods were the best, but we have found that Stringless Green Pod
beats them all for crispness and tenderness. We have noticed also that the pods hold tlieir crispness right along until the beans are nearly ripe. You will find that nearly all seedsmen are giving this variety first place now as the best of all dwarf green pods, and one that is absolutely stringless. The pods are five inches long, of a rich green color, very round and straight (see illustration op posite). By repeated plantings, fine pods may be had in constant succession from spring until cut off by heavy frosts in the fall. For either the market or home garden, no other green podded bean is so entirely satisfactory. We will let you try it for yourselves. Pkt., 10 c.s.; 2 pkts., 15 cts.; pt., 20 cts.; qt., 35 cts., postpaid. By express or freight, not prepaid: Qt., 20 cts.; 1/2 pk., 75 cts.; pk., $\$ 1.45$; bu., $\$ 5.00$.

FREE SAMPLES FOR TRIAL. See page 13.

\section{OLDS' PENGIL POD WAX.}

18, $\star A$ new Wax Bean, very early very productive, and of most excellent flavor. The pods are long, straight,
roind like a pencil (see illustration), fieshy, and of a bright yellow color: tender, brittle and absolutely stringless. TVe think this is the best wax pod Bean for the home gardentry it. Pkt., 10 cts.; pt., 20 cts.; qt., 35 cts.; postpaid. By express or freight, not prepaid: Qt., 20 cts.; $1 / 2$ pk., 80 cts.; pk., \$1.50; bu., $\$ 5.50$. 23. JONES' STRINGLESS WAX. A fine wax pod variety. A week earlier than Black JVax, with pods perfectly round, solid and tender. Pkt., 5 cts.; pt., 20 cts.; qt., 35 cts., postpaid. By express or freight, not prepaid: Qt., 20 cts.; pk., $\$ 1.45$; bu., $\$ 5.25$.

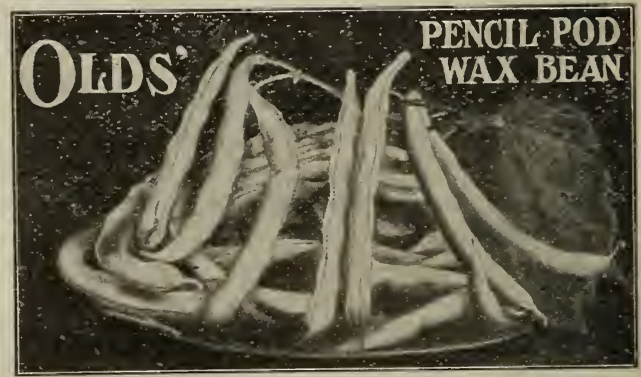

GURRIE'S RUST-PROOF WAX.

24 . $\star$ The best Wax Bean for Market Gar deners - Proof Against Rust. Early and productive; pods straight, rather flat (see illustration), five inches long, of a light golden yel low : of very fine flavor and most excellent quality; crisp, tender and entirely stringless. Pkt., 5cts.; pt., 20 cts.; qt., 35 cts., postpaid. Not prepaid: Qt., 20c; pk., $\$ 1.25$; bu., $\$ 4.00$

WARDWELL'S KIDNEY WAX.

17. About the earliest, hardiest and most productive of all wax pods. Famous with market gardeners. Pods are long and showy, a third longer than Golden Wax, and a week earlier. A rich, golden yellow, brittle and en tirely stringless. Pkt., 10 cts.; 2 pkts., 15 cts.; pt., 25 cts.; qt., 40 cts., postpaid. Not prepaid: Qt., 25 cts.; pk., \$1.75; bu., $\$ 6.50$. 


\section{BURPEE'S BUSH LIMA BEAN. THE BEST BUSH LIMA.}

26. $\star$ This is the only bush form of the true Lima bean. Nothing is quite so delicious in the regetable line as fresh Lima beans, right from the garden. But the

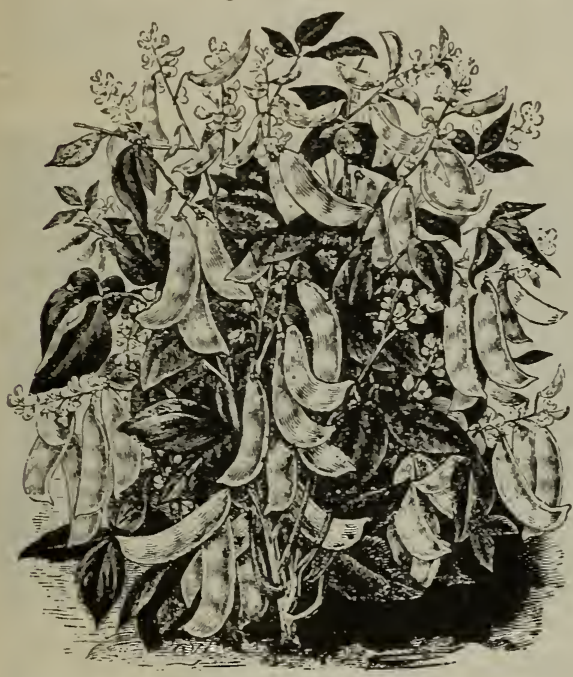

The Best Bush Lima Bean. old pole Limas are not easy to
raise in the north. Burpee's Bush Lima, lowever, can be successfu!ly grown by any one, and it ought to be in every garden. The bushes grow 18 to 20 inches high, of stout, erect growth, requiring no Each nod contains 3 or 4 mammoth beans; very tender and of a most delicious flavor. Every one testifies to the worth of this variety. 20 cts.; qt., 35 cts., postpaid. By express or freight, not prepaid: Qt., 20 cts.; pk., \$1.50; bu., \$5.50.

Write us for special prices on larger quantities-see Discounts, Page 45. Any 3 ten-cent pkts. for $25 \mathrm{cts}$.

"I received your catalogue, and as my neighbor gets his seed from you, so I want to try you this year. I have been getting my seed from another seedsman in this Stateplease send me the extras.

April 23, 1906.

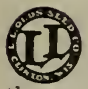

22. OLDS' BEST OF ALL BUSH. One of the finest and most productive of all the Green Pod Bush varieties. The plants grow erect, 18 to 20 inches in height, bearing a profusion of long, straight pods, well above the soil. The pods are fleshy, succulent, stringless and of extra fine flavor, altogether one of the most desirable both for market and home use. Pkt., 5 cts.; pt., $20 \mathrm{cts}$.; qt., 30 cts., postpaid. By express or freight, not prepaid: Qt., 15 cts.; pk., $\$ 1.00$; bu., $\$ 3.50$.

25. GIANT GREEN POD VALENTINE. A new Stringless Green Pod. Round, stringless pods, a week earlier and a third larger than Red Valentines. No grower need fear to plant this most valuable new Bean. We can and do recommend it. Pkt., 5 cts.; pt., 20 cts.; qt., 35 cts., postpaid. By express or freight, not prepaid: Qt., 20 cts.; pk., $\$ 1.25$; bu., $\$ 4.50$.

32. LAZY WIFE. POLE. The most popular Pole Bean in cultivation today. Stringless and of a rich, buttery flavor when cooked. The pods are dark green in color, $4 \frac{1 / 2}{1}$ inches in length, and are produced in great abundance. The beans are white and unsurpassed as shell beans for winter use. Price same as Burpee's Bush Lima.

33. GOLDEN CLUSTER WAX POLE. This is one of the finest of all the Pole Beans. The pods are 6 to 8 inches long; they are borne in large clusters, and are a beautiful yellow color, which they retain a long time after being picked. They snap easily, are stringless and very delicious - can be used either as a snap short or shell winter bean. Pkt., 10 cts.; 2 pkts., 15 cts.; pt., 20 cts.; qt., 35 cts., postpaid. By express or freight, not prepaid: Qt., 20 cts.; pk., $\$ 1.50$; bu., $\$ 5.50$.

36. GOLDEN GARMINE. A new Horticultural Pole Bean. The pods grow frum 6 to 8 inches long (see illustration, two-thirds natural size). It is ten days earlier than the old Horticultural and a stringless variety. The pods are very tender, and remain so for a long time. It is also fine as a shell bean for winter. It is very productive, and we believe will prove satisfactory to all who plant it. Pkt., 10 cts.; 2 pkt3., 15 cts.; pt., 20 cts.; qt., 35 cts., postpaid. By express or freight, not prepaid: Qt., 20 cts.; pk. $\$ 1.25$; bu., $\$ 4.50$.

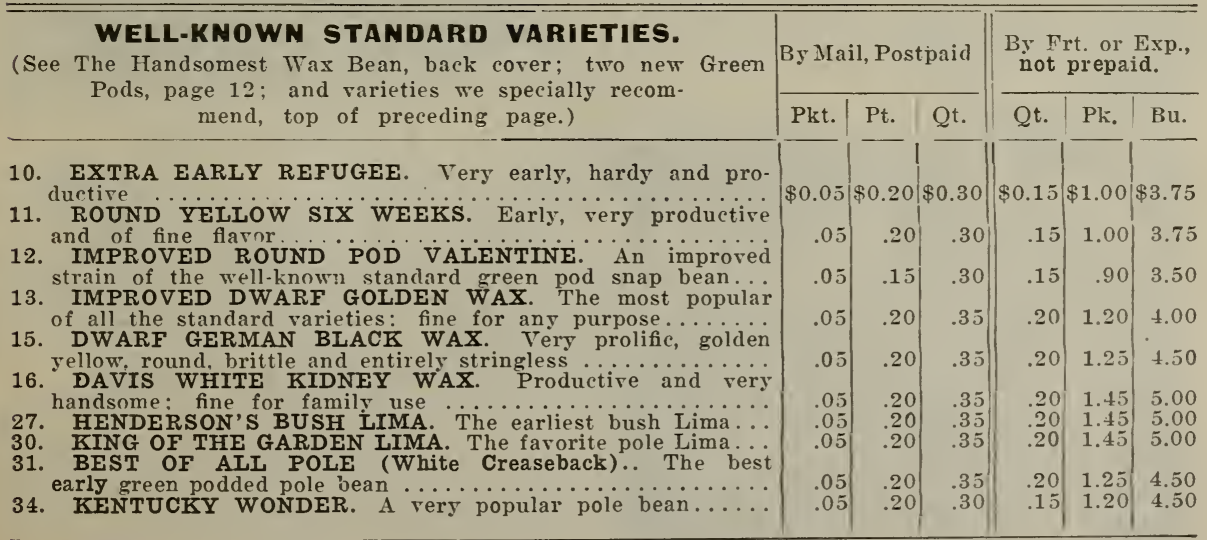




\section{BEETS}

OUR BEET SEED IS IMPORTED. We find imported seed produces better beets than seed grown in this country. We test all the seed (see page 45) and try every variety in the trial grounds-see illustration, a photograph from our trial grounds. We take great care to have seed that will produce beets free from rootlets and uniform in size. Our packets each contain $1 / 4$ oz. of seed and will plant from 12 to 15 feet of drill; five to six pounds, one acre. Order by number.

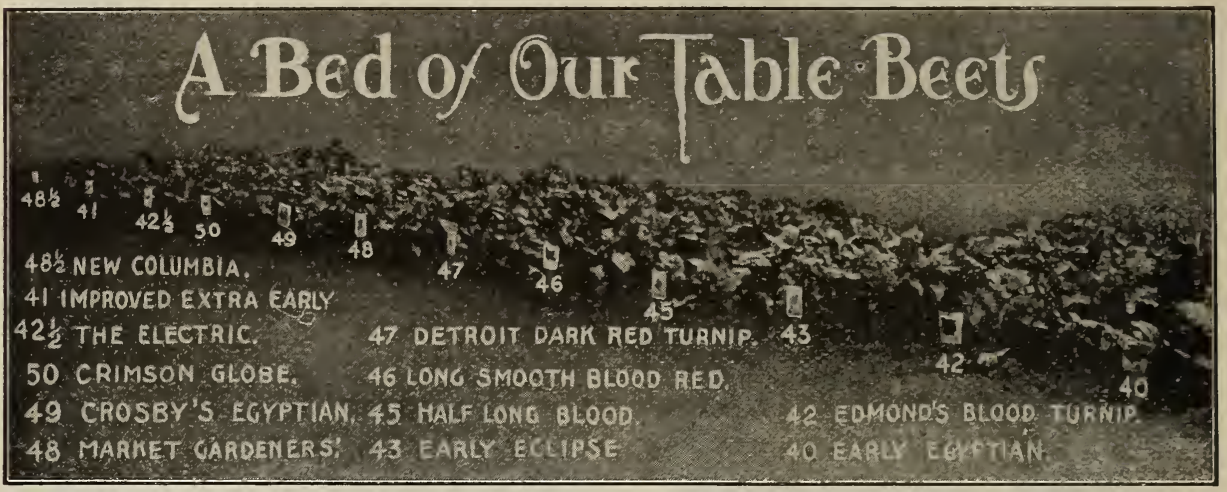

VARIETIES WE SPECIALLY RECOMMEND.

41. OLDS' IMPROVED BLOOD TURNIP. The best first early beet.

50. CRIMSON GLOBE. The most suitable beet for a main crop.

44. NEW EARIY MODEL. The perfect beet. See page 12

\begin{tabular}{|c|c|c|c|c|}
\hline kt. & oz. & $1 / 4 \mathrm{lb}$. & lb. & $5 \mathrm{lbs}$ \\
\hline 0.05 & T30.10 & $\$ 0.15$ & $\$ 0.5$ & $\$ 2$ \\
\hline .05 & .10 & .15 & 40 & 1.75 \\
\hline $0=5$ & 1 & .20 & .70 & 3.00 \\
\hline
\end{tabular}

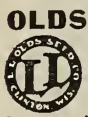
41. The Early Blood Turnip Beet is one of the best-known and most popular of the early sorts. Olds' Improved is very smooth, of medium size (see illustration opposite), dark red flesh, fine grain, very sweet and tender. It grows quickly, with small, uniform tops, and is the best first early. Pkt., 5 cts.; oz., 10 cts.; 1/4 lb., 15 cts.; lb., 50 cis.; 5 lbs., $\$ 2.00$, postpaid.

\section{THE ELEQTRIG.}

121/ The best second early beet. The Electric is a thoroughbred, remarkably uniform in shape and size, with smooth, dark red skin, small leaves and a small tap root. The flesh is fine grained and tender; color, rich red, ringed with dark crimson. We recommend the Electric Beet to all those wanting a fine early table beet. Pkt., 5 cts.; oz., 10 cts.; 1/4 lb., 15 cts.; lb., 50 cts.; 5 lbs., $\$ 2.00$, postpaid.

$481 / 2$. NEW GOLUMBIA. A superb maincrop variety. This Beet orows from 3 to 4 in. in diameter; smooth and free from small rootlets. Flesh deep blood-red, tender and of rich flavor. It retains its fine qualities until nearly full size. Compared with the large standard varieties, Columbia has proven earlier than any, and best of all in quality. Price same as for Electric.

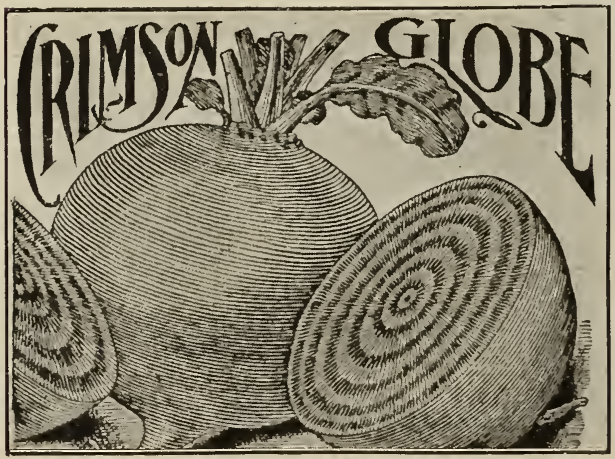

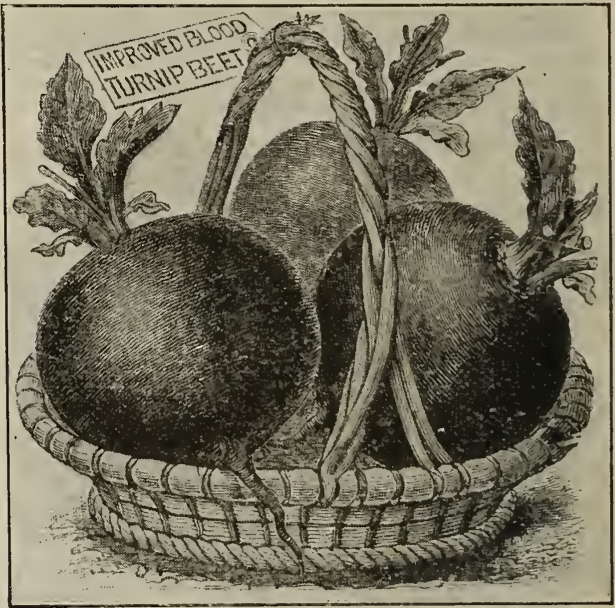

GRIMSON GLOBE,

50. $\downarrow$ A new variety of great merit. Unequaled for table use; very handsome, early, most suitable for a main-crop variety, of medium size, almost globe-shaped and free from rootlets (see illustration). The flesh is a deep purplish crimson and of the finest quality, always sweet and tender, and never stringy. Pkt., 5 cts.; oz., 10 cts.; $1 / 4$ lb., 15 cts.; lb., 40 cts.; 5 lbs., $\$ 1.75$, postpaid.

\section{GROSBY'S EGYPTIAN.}

49. The most desirable early market Beet. A selection from Early Egyptian, which is the standard extra early market beet. It retains the earliness of its parent, but has a more desirable shape, being rounder. Deepest red in color, being almost black, and of even better quality than Egyptian. Pkt., 5 cts.; oz., 10 cts.; 1/4 lb., 15 cts.; lb., 40 cts.; 5 lbs., $\$ 1.75$, postpaid. 


\section{BEETS. WELL-KNOWN STANDARD VARIETIES.}

If ordered by express or freight, deduct $10 \mathrm{cts}$. per $1 \mathrm{~b}$. $2 \mathrm{lbs}$. or more at $5-1 \mathrm{~b}$. rates.

40. IMPROVED EARLY EGYPTIAN. The standard market variety, best for forcing. Grows quickly, producing smooth, flat, turnipshaped roots averaging two inches or more in diameter...

42. EDMAND'S EARLY BLOOD TURNIP. Dark red; fine flavor; good for winter use; one of the best beets grown; can be planted closely, as it has a very small top.

43. EARLY ECLIPSE. Very early, globe-shaped, with small top, thin root; skin bright red; flesh fine and excelled by none. Popular both for market and the home garden.

45. HALF LONG BLOOD. Best for winter use. Always smooth, crisp and tender, remaining so until late in the season; dark red flesh.

46. LONG SMOOTH BLOOD-RED. Old stand-by. A well-known win-

ter beet; late in maturing, but an excellent keeper.

47. DETROIT DARK RED TURNIP. A very fine early turnip beetone of the best for the ntarket garden; dark red skin, and bright red flesh; smooth, tender and sweet

48. MARKET GARDENERS'. The great all-seasons beet; splendid for autumn or winter use. Makes a rapid growth and a heavy root; sweet and crisp

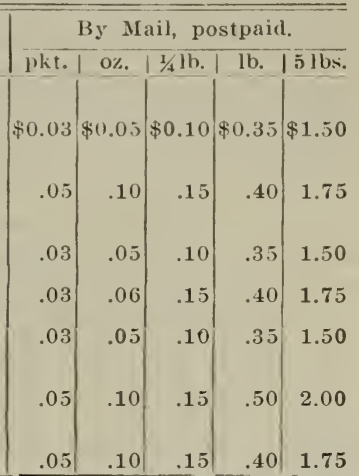

MANGELS AND SUGAR BEETS

Five or six pounds of seed will sow an acre. If ordered by express or freight, deduct $10 \mathrm{c}$ per $\mathrm{lb}$. Mangels are good keepers and immensely productive. They increase the flow of milk for cows; are also relished by horses, hogs and sheep. 35 to 50 tons can be readily grown to the acre.

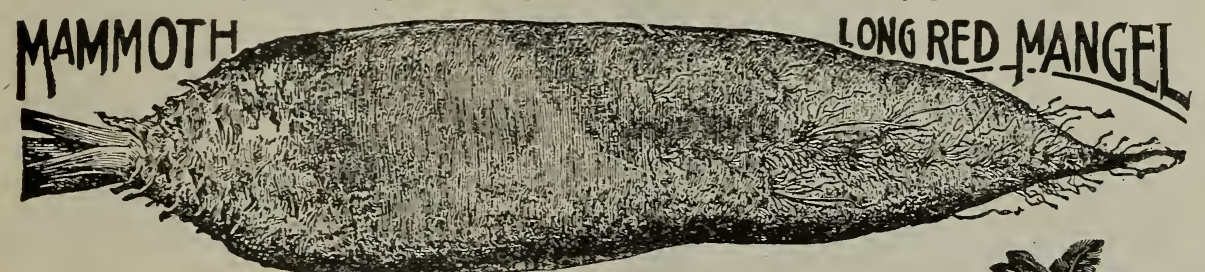

55. MAMMOTH LONG RED. Very productive, often yielding 50 tons to the acre. It grows well abore the ground and is easily pulled. It is the best long red Mangel, and of the greatest value for stock feeding. (See illustration above.) Oz., 5 cts.; 1/4 lb., 10 cts.; lb., $30 \mathrm{cts}$; 5 lbs., \$1.40, postpaid.

56. GOLDEN TANKARD. The best yellow Mangel in cultivation. It contains a larger percentage of sugar than the red Mangels; rery desirable and easily pulled - see illustration. Oz., 5 cts.; 1/4 lb., $10 \mathrm{cts}$.; lb., $30 \mathrm{cts}$.; 5 lbs., $\$ 1.40$, postpaid.

57. GOLDEN GIANT INTERMEDIATE. Root interme liate between the long and the globe-shaped. Flesh white, firm and sweet, much liked by cattle. Oz., 5 cts.; 1/4 lb., 10 cts.; 1b., 25 cts.; 5 lbs., $\$ 1.20$, postpaid.

58. CHAMPION YELLOW GLOBE. The best globe-shaped Mangel. Oz., 5 cts.; 1/4 lb., 10 cts.; lb., 20 cts.; 5 lbs., 95 cts., postpaid.

59. RED GLOBE. Early and smooth. Globe-shaped, red in color, and often 8 inches in diameter. Prices same as for Yellow Globe.

\section{SUGAR BEETS.}

Price: Oz., 5 cts.; 1/4 lb., 10 cts.; lb., 30 cts.; 5 lbs., $\$ 1.40$, postpaid. 60. LANE'S IMPERIAL. A great farorite with stockmen. Not so rich in sugar as Vilmorin's, but larger and more profitable to grow for feeding.

61. KLEIN WANZLEBEN. Largely grown for Sugar Beets. The root is straight and even. A heavy vielder and rich in sugar.

62. VILMORIN'S IMPROVED. An improved French variety, very rich, containing usually as high as 16 per cent of sugar.

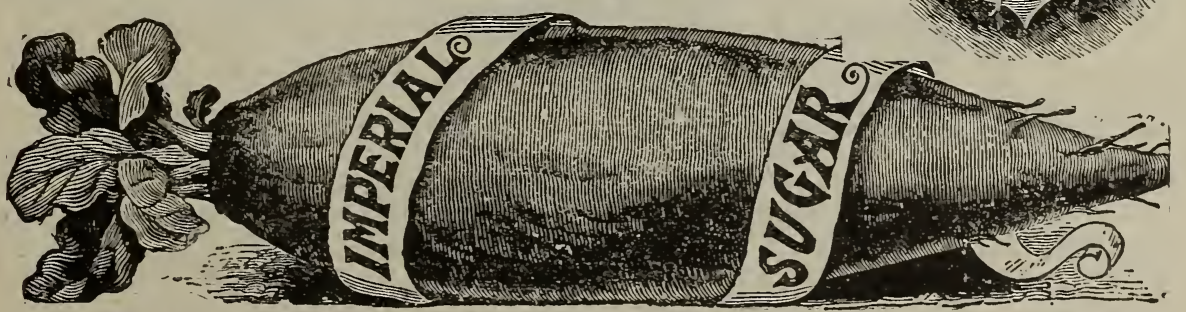

65. BRUSSELS SPROUTS. A most delicious regetable-used as greens; rery tender and rich, after being touched by frost. Pkt., 5 cts.; 0z., $10 \mathrm{cts}$.; 1/4 lb., $25 \mathrm{cts}$., postpaid.

"I had some of your seeds last spring; they were good; had the best garden I ever had." J. W. Rogers, Mazomanie, Wis., April 4th, 1905.

DON'T MISS OUR COLLECTIONS-Pages 69 and 70. 


\section{CABBACE}

Excepting the potato, cabbage is now more extensively grown for market than any other vegetable. We exercise the greatest care in selecting our cabbage seed-all of it is the best Americangrown, excepting Ballheal, which can only reach perfection in Denmark. Our packets each contain 1-6th oz. of seed, sufficient to produce 500 plants; $1 / 41 \mathrm{l}$. will plant one acre.

Order by number. If ordered by express or freight, deduct 10 cts. per lb. Half-pounds at pound rates.

VARIETIES WE SPECIALLY RECOMMEND.

70. OLDS' SELECT EARLY JERSEY WAKEFIELD. The most pupular 74. ALLHEAD EARLY. The best all-the-year-round cabbage; good fo

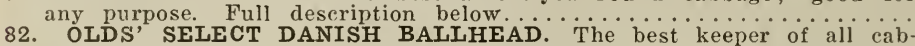

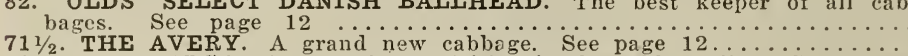

$73 \frac{1}{2}$. THE VOLGA. A valuable acquisition in the cabbage line. Sce p. 12

\begin{tabular}{|c|c|c|c|}
\hline \multicolumn{4}{|c|}{ By Mail, postpaid. } \\
\hline pkt. & oz. & $1 / 4 \mathrm{lb}$. & lb. \\
\hline$\$ 0.05$ & $\$ 0.15$ & $\$ 0.40$ & $\$ 1.50$ \\
\hline .05 & .10 & .35 & 1.25 \\
\hline .05 & .15 & .40 & 1.50 \\
\hline .1 & .20 & .70 & 2.50 \\
\hline .10 & .20 & .60 & 2.00 \\
\hline
\end{tabular}
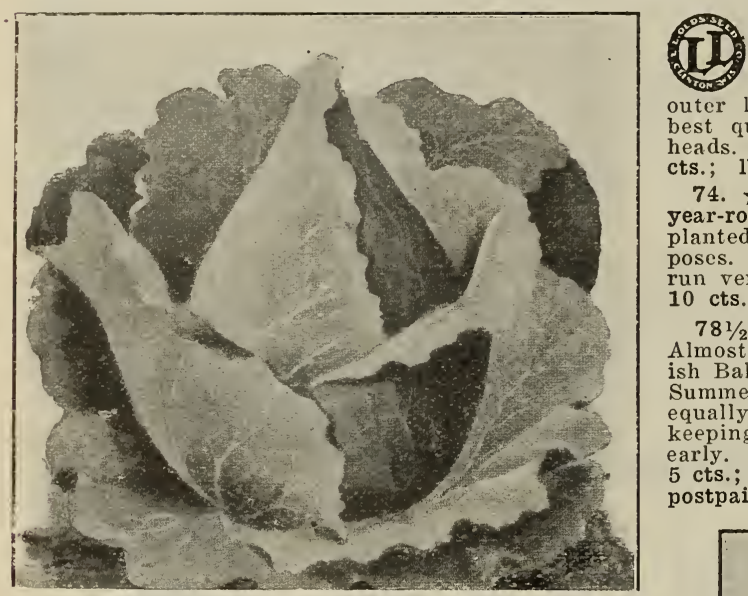

70. ` OLDS' SELECT EARLY JERSEY WAKEFIELD: The best early cabbage in cultivation. It forms fine, solid heads of good size, very few outer leaves (see illustration), and is of the best quality. Seed grown only from selected heads. Pkt., 5 cts.; oz., 15 cts.; 1/4 lb., 40 cts.; lb., \$1.50, postpaid.

74. * ALLHEAD EARLY. The best all-theyear-round cabbage; if only one variety is planted, nothing is better than this for all purposes. The heads are deep, flat and solid and run very uniforın in shape Pkt., 5 cts.; oz 10 cts.; 1/4 lb., 35 cts.; lb., \$1.25, postpaid.

78 $\frac{1}{2}$. DANISH SUMMER BALL HEAD. Almost everybody is now acquainted with Danish Ball Head Calbage (see page 12). Danish Summer Ball Head is an early variety and equally as hard as the original, with the same keeping qualities. It is an excellent second early. Best Imported Danish-grown Seed: Pkt., 5 cts.; oz., 10 cts.; 1/4 lb., 35 cts.; lb., \$1.25, postpaid.

Clds' Select Early Jersey Wakefield.

$75 \frac{1}{2}$. THE HOUSER. This is fast becoming the favorite of all the newer varieties of late winter cabbage. The heads are large, perfect in every respect as to size, weight, quality, smallness of heart, sure-heading and longkeeping qualities-see illustration. The Houser is a strong grower, and withstands drought better than most varieties. Pkt., 5 cts.; oz., 15 cts.; 1/4 lb., 45 cts.; lb., \$1.75, postpaid.

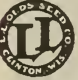

79. OLDS” BRIDGEPORT DRUMHEAD.

We offer this as a most select strain of this finest of all Drumheads. Our seed is grown only from the largest and most perfect heads. It makes a $1 / 4$ lb., 40 cts.; lb., $\$ 1.50$, postpaid.

83. PREMIUM FLAT DUTCH. This is a greatly improved strain of the old favorite cabbage. The Flat Dutch is very largely grown for main crop. It is the most profitable cabbage grown and a great farorite for general use. Pkt., 5 cts.; oz., 10 cts.; 1/4 lb., 35 cts.; lb., \$1.25, postpaid.

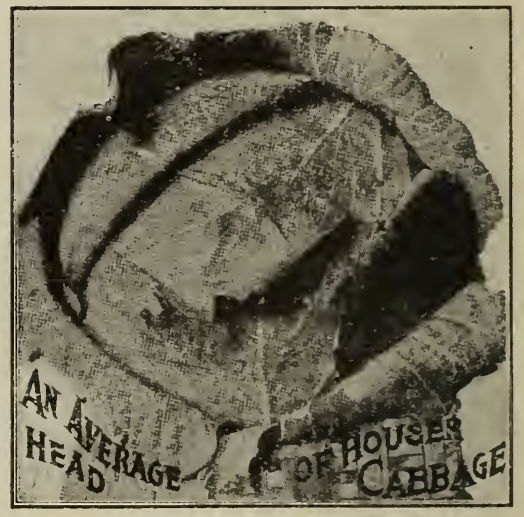

WELL-KNOWN STANDARD VARIETIES

If ordered by express or freight, deduct $10 \mathrm{cts}$. per $1 \mathrm{~b}$. Half-pounds at pound rates.

71. EXTRA EARLY EXPRESS. Earliest of all. Small pointed heads

72. LARGE WAKEFIELD or CHARLESTON. About a week later than Jer-

73. EA Wakefield and about half as large again.......

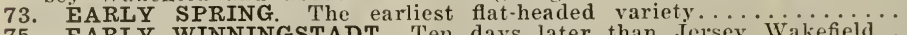

75. EARLY WINNINGSTADT. Ten days later than Iersey Wakefield...

77. ATNERON'S SUCCESSION Second early

78. SURE HEAD. All Head and sure to head.

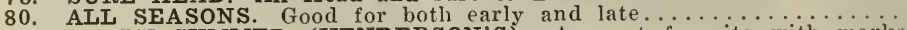

81. EARLY SUMMER (HENDERSON'S). A great favorite with market

gardeners; large, solid, compact heads

85. MAMMOTH ROCK RED. Hard-heading; fine for pickling.

86. PERFECTION DRUMHEAD SAVOY The best of all the cavoys...

87. FILDERKRAUT. Pointed heads; best for kraut

88. RED DUTCH. Best red Cabbage for pickling.

\begin{tabular}{l|r|r|r}
\multicolumn{4}{c}{ By Mail, postpaid. } \\
\hline pkt. & \multicolumn{1}{c}{ oz. } & \multicolumn{1}{|c}{ 1/4lb } & \multicolumn{1}{l}{ lb. } \\
\hline$\$ 0.05$ & $\$ 0.10$ & $\$ 0.35$ & $\$ 1.25$ \\
.05 & .10 & .35 & 1.25 \\
.05 & .15 & .40 & 1.40 \\
.05 & .10 & .30 & 1.00 \\
.05 & .10 & .30 & 1.00 \\
.05 & .10 & .35 & 1.25 \\
.05 & .10 & .35 & 1.25 \\
.05 & .15 & .40 & 1.50 \\
.05 & .15 & .40 & 1.40 \\
.05 & .15 & .45 & 1.75 \\
.05 & .10 & .35 & 1.25 \\
.05 & .10 & .35 & 1.25 \\
.05 & .10 & .35 & 1.25 \\
\hline
\end{tabular}

Two New Cabbages (page 12). Use Slug Shot for Cabbage Worms (page 83). 


\section{CARROT}

The Carrot is one of the most uutritious and heatliful of roots and ouglit to be more generally used for the table as well as for stock feeding. Our Carrot seed is all grow frum curefully roots-true to type- and our list comprises the best table and field sorts. Our packets each contain $1 / 4$ oz. of seed, sufficient for a drill 50 feet long. Three pounds will sow an acre in drills 2 feet apart.

If ordered by express or freight, deduct 10 cts. per ll). Two $1 \mathrm{bs}$. or more at 5.1b. rates.

\section{VARIETIES WE SPECIALLY RECOMMEND.}

$100-D A N V E R S$ HALF LONG. $\Lambda$ general favorite both for table use

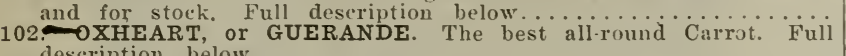
103 EARLY CHANTENAY. Probably the most profitable of all car $1001 / 2-$ EARLY SHORT TOP. The best carrot for family use. See p. is

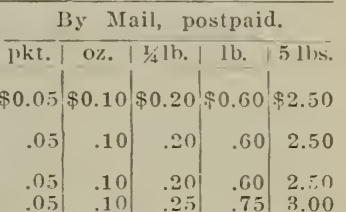
100 . DANVERS HALF LONG. Stump rooted (see ilbest flavor and a most wouderful producer. Easily harvested and a farorite, both for table use and stock. Pkt., 5 cts.; oz., 10 cts.; $11 / 4$ lb., 20 cts.; lb., 60 cts.; 5 lbs., $\$ 2.50$, postpaid.

I02. $\star 0 \times$ H EAR T, or GUERANDE. (Stump-rooted). The best all-rouxd Carros. Very thick, 5 inches long and nearly as broad, and rery blunt at the lower extremities (see illustration). Equally good for table use or stock. Pkt., 5 cts.; oz., 10 cts.; 1/4 1b., 20 cts.; lb., 60 cts.; 5 lbs., \$2:50, postpaid.

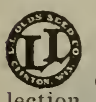

\section{0ก OLDS' IMPROVED LONG}

\section{ORANGE I standard late rariety} (see illustration); deep orange color: of recent years much improved by selection of the best formed and deepest col15 cts.; lb., 45 cts.; 5 lbs., $\$ 2.00$, postpaid.

103. TEARLY CHANTENAY. Very early, and. altogether the most profitable of all early Carrots. Grows fire or six inches long, very smooth (see illustration). Primarily a table carrot, but also profitable for stock. Price, same as Danvers.

10 NANTES HALF LONG SCARLET. A very fine early variety and the sweetest of all Carrots. The roots are very smooth (see illustration). Price, same as Improved Long Orange.
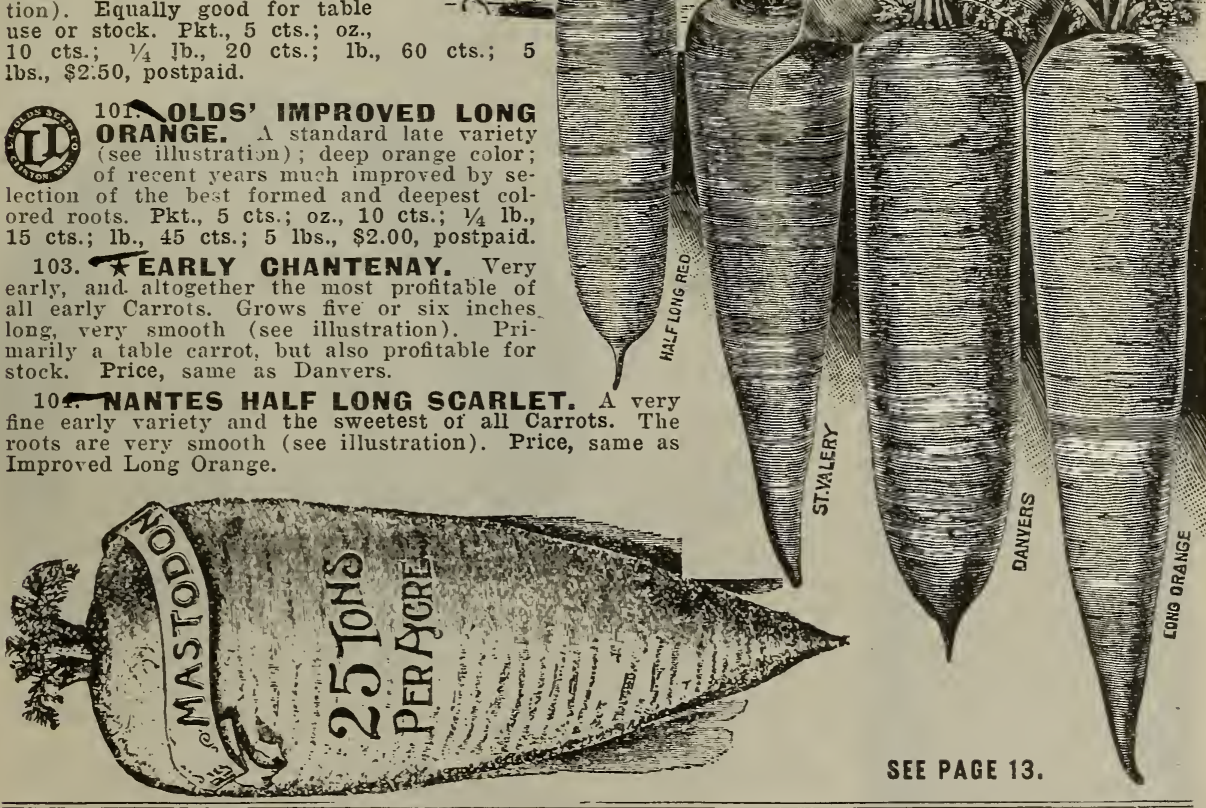

WELL-KNOWN STANDARD VARIETIES.

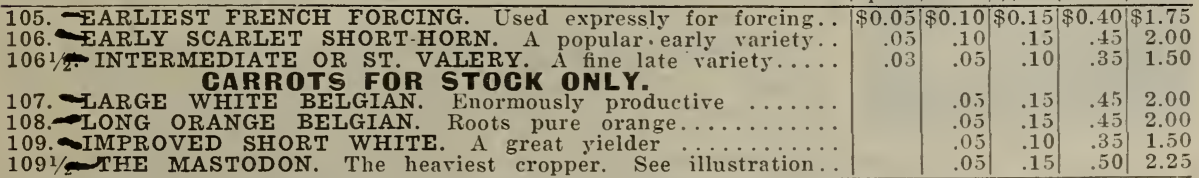

121. CHICORY Large Rooted. Fine for salads, with oil and vinegar; roots - a good substitute for coffee. Pkt., 5c; oz., 10c; $1 / 4$ 1b., 20c; 1b., $60 \mathrm{c}$.

154. CRESS. Extra Curled." (Pepper Grass.) The best variety. Every one should sow a little for early spring use. Pkt., $5 \mathrm{c}$; oz., $8 \mathrm{c} ; 1 / \frac{1}{4} \mathrm{lb} ., 15 \mathrm{c}$,
150. COLL.ARDS.

150. CoLLARD . A . Southern cabbage. 152. CORN SAIAD. A fine salad and a good substitute for lettuce. Pkt., $5 \mathrm{c}$; 0z., $10 \mathrm{c} ; 1 / 41 \mathrm{~b} ., 20 \mathrm{c}$. 120. CELSRIAC. Turnip-rooted Celery; fine for soup. Pkt., 5c; oz., 15c. Celery-page 55. 


\section{SWEET CORN}

Our Sweet or Sugar Corn is all properly cured and first-class in every respect. Sweet Corn should not be planted until the ground is warm - see cultural directions on the back of each package. Plant at intervals of two weeks until July; yon will then have corn at the proper stages from July to October. Our packets each contain $1 \frac{1}{2}$ ounces; sufficient to plant 20 hills. One peck will plant 1 acre in hills. We have a good crop of Sweet Corn this year and give our customers the beneit by making frices low. Order ly number.

VARIETIES WE SPECIALLY RECOMMEND. By Mail, postpaid. By Frt. or Exp., not prepaid. rates when not otherwise quoted.

125. PEEP O' DAY. A new extra early. Described as the "ear132. EARLY CHAMPION. The best all-round second early.

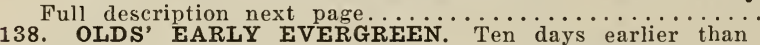
138. OLDS' EARLY EVERGREEN. Ten day 114. WHITE MEXICAN. The best early market variety. See page 13

\begin{tabular}{|r|r|r||r|r|r}
\hline Pkt. & Pt. & Qt. & Qt. & Pk. & Bu. \\
\hline$\$ 0.05$ & $\$ 0.15$ & $\$ 0.25$ & $\$ 0.15$ & $\$ 1.00$ & $\$ 3.00$ \\
.05 & .15 & .25 & .15 & .75 & 2.50 \\
.05 & .15 & .25 & .15 & $.7 \$$ & 2.50 \\
.10 & .20 & .30 & .20 & 1.25 & 3.75 \\
\hline
\end{tabular}

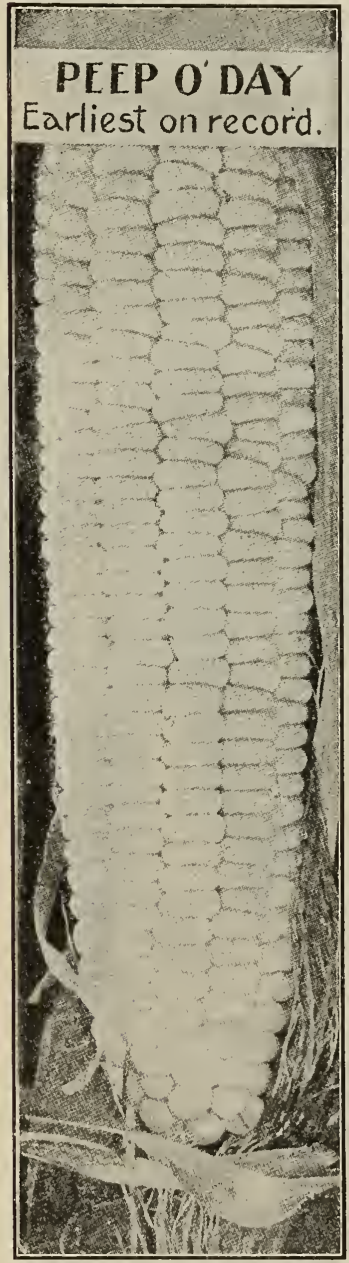

\section{PEEP O' DAY.}

125. ^ A new Extra Early. Described as the "earliest on earth." Originated in Minnesota; ears 5 inches long, perfectly formed, and well filled-see illustration. The corn is very tender and sweet. In our trial grounds, Peep O' Day proved decidedly, earlier than Bantam and other so-called extra earlies. We believe it is the earliest variety of Sweet Corn yet introduced. Pkt., 5 cts.; pt., 15 cts.; qt., 25 cts., postpaid. By express or freight, not prepaid: Qt., 15 cts.; pk., $\$ 1.00 ;$ bu., $\$ 3.00$.

\section{OLDS' EARLY EVERGREEN.}

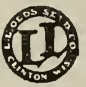

138. \ Like Stowell's Evergreen, only ten days earlier. Large ears - see illustration. About 8 inches long and 12 to 16 rowed, and identical in flavor with the famous Stowell's Evergreen. This new variety is indispensable to the market gardener as a succession to the second earlies. Equally desirable for the home garden. Two plantings will cover the entire season. Pkt., 5 cts.; pt. 15 cts.; qt., 25 cts. postpaid. By express or freight, not prepaid: Qt., 15 cts. pk., $75 \mathrm{c}$; bu., $\$ 2.50$.

\section{PREMO.}

\section{Claimed to} be the best early Sweet Corn in cultivation. First introduced in 1900. A genuine Sweet Corn, as early as the Adams Extra Early. The Premo reaches maturity in from 56 to 60 days from planting, and it not only combines all the merits of the leading early varieties, but is really superior to many of them in size, quality and appear ance. Pkt., 5 cts.;

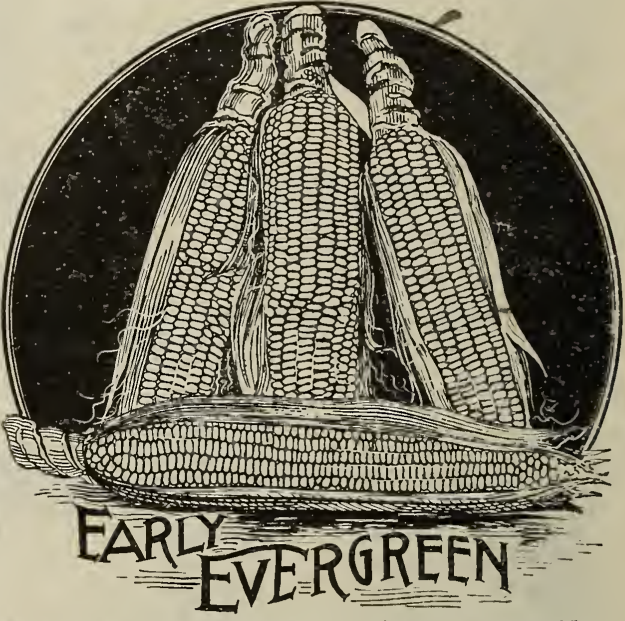
pt., 15 cts.; qt., 25 cts., postpaid. By express or freight, not prepaid: Qt., 15 cts.; pk., 80 cts.; bu., $\$ 2.75$

143. GOLDEN BANTAM (BURPEE'S). Claimed to be the earliest Sweet Corn, but with us, planted at the same time with Peep $O^{\prime}$ Day, Cory and other early varieties, it matured 10 days after Peep $O^{\prime}$ Day. The Bantam originated in Massachusetts; is a deep yellow in color and very sweet. We have the genuine. Pkt., 5 cts.; pt., 15 cts.; qt., 25 cts., postpaid. By express or freight, not prepaid: Qt., 15 cts.; pk., 70 cts.; bu., $\$ 2.25$.

127. COUNTRY GENTLEMAN. Without doubt the sweetest and most delicious flavored sweet corn grown; also one of the most productive, each stalk producing from 3 to 5 ears. Kernels are very, deep and cob small. Season medium. Pkt., 5 cts.; pt., 15 cts.; qt., 25 cts., postpaid. Not prepaid: Qt., 15 cts.; pk., 75 cts.; bu., $\$ 2.50$.

SIZE OF PACKETS. - With most Seedsmen the word "Paeket" is rather an indefinite quantity; it may mean many or few seeds. We think this is a very important point to seed buyers. We state under the heading of each variety the quantity of seed eacli packet contains and how much ground it will plant, also how much seed it requires to plant an acre.. 


\section{THE BEST THREE FOR SUCCESSION.}

One pkt. each, 10 cts.; one pt. each, 35 cts.; one qt. each, 65 cts., postpaid. By express or freight, not prepaid: One qt. each, 35 cts.; one pk. each, $\$ 2.00$.

126. MАMMOTH WHITE CORY. Our earliest rariety, with the exeeption of Peep O' Day. It

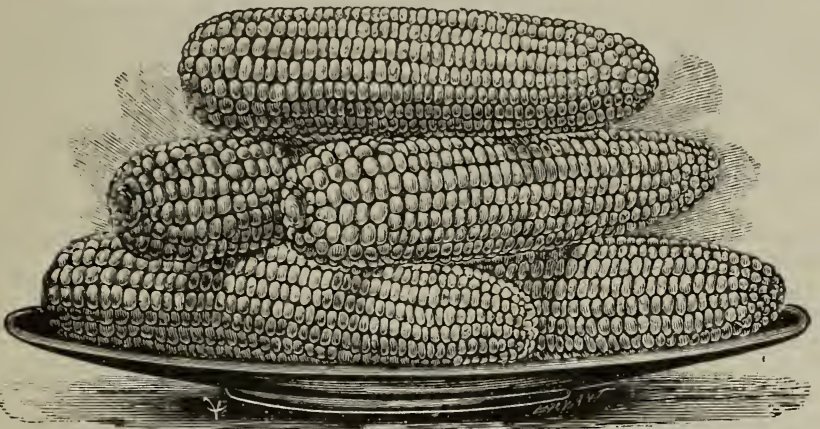
is large but not mammoth. The name "IIammoth" should not have been given to it, as it indicates something very large. Mammoth White Cory is no later than the old Cory, so famous as the standard ex ra early, but is 12 -rowed in stead of 8-rowed, and the ears are quite good-sized (see il. lustration opposite), which makes it a much more valuable variety. The grain is large, broad, pure white, and of excellent quality for an extra early. Pkt., 5 cts.; pt., 15 cts.; qt., 25 cts., postpaid. By express or freight, not rrepaid: Qt., 15 cts.; pk.,

132. EARLY CHAMPION. The Earliest Large Sweet Corn. Produces ears twelve inches long in sixty days. Only a few days later than the small early sorts, and ears nearly as large as the largest late sorts. (See illustration.) Kernels are pure white, with white cob; very sweet and tender and full of milk. If you want but one variety for both early and late, for table use and for stock, plant Early Champion. Pkt., 5 cts.; pt., 15 cts.; qt., 25 cts., postpaid. By express or freight, not prepaid: Qt., 15 cts.; pk., 75 cts.; bu., $\$ 2.50$.

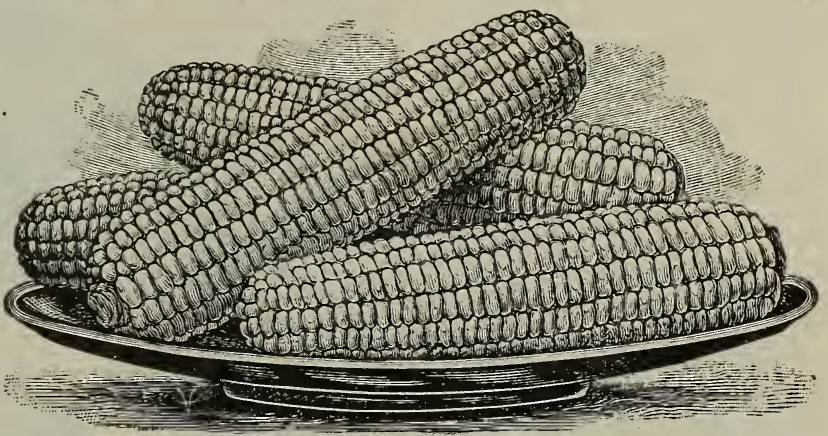

139. STOWELL'S EVERGREEN. The best late Sweet Corn for any purpose. Well known and very popular ererywhere. It is very large eared (see il lustration), very hardy and productive, sweet and tender, and remains a long time in suitable condition for cooking. Our seed is very care fully selected for large ear and deep kernel. Pkt., 5 cts.; pt., 10 cts.; qt., 20 cts., postpaid. By express or freight, not prepaid: Ot., 10 cts.; pk., 60 cts.; bu., $\$ 2.00$;

bus. or more $\$ 1.85$ per bu.
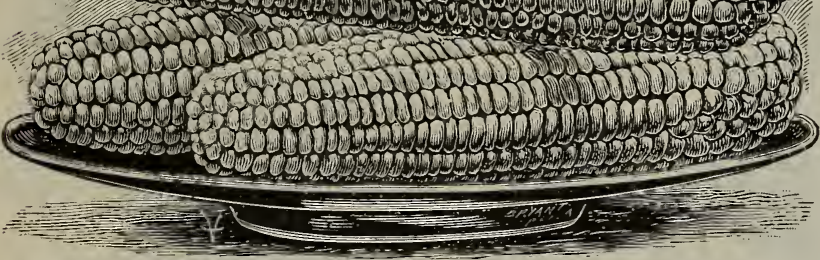

Select $\$ 1.00$ worth of packets and ounces and remit 75 cts. See page 45.

\section{FIRST EARLY VARIETIES.}

Pints, half-pecks and half-bushels at qt., pk. and bu. rates.

128. EARLY MINNESOTA. Nearly as early as Cory; of dwarf growth: ears white, very sweet and tender.

129. CHICAGO MARKET. A great favorite in Chica market

130. PERRY'S HYBRID. A good second early, of large size.

131. METROPOLITAN. Henderson's New Corn

136. CROSBY'S EARLY. A favorite with can

13. KENDEL'S GIANT. A wonder

137. COSMOPOLITAN. A new variety : VARIETIES

140. ZIG-ZAG EVERGREEN . Large kernels, very sweet.

111. WHITE EVERGREEN. A new variety. Pure white.

142. LATE MAMMOTH. This variety produces the largest ears

of any sort. It is excellent, sweet and tender

FODDER EVERGREEN. See Field Seeds, page 33

\begin{tabular}{|c|c|c|c|c|c|}
\hline \multicolumn{3}{|c|}{$\begin{array}{l}\text { By Mail, } \\
\text { postpaid. }\end{array}$} & \multicolumn{3}{|c|}{$\begin{array}{l}\text { By Exp. or Frt., } \\
\text { not prepaid. }\end{array}$} \\
\hline pkt. & pt. & qt. & $\mathrm{qt}$. & pk. & bu. \\
\hline$\$ 0.05$ & $\$ 0.15$ & $\$ 0.25$ & $\$ 0.15$ & $\$ 0.70$ & $\$ 2.25$ \\
\hline .05 & .10 & .20 & .10 & .60 & 2.00 \\
\hline .05 & .10 & .20 & .10 & .60 & 2.00 \\
\hline .05 & .15 & .25 & .15 & .75 & 2.50 \\
\hline .05 & .10 & .20 & .10 & .60 & 2.00 \\
\hline .05 & .15 & .25 & .15 & .70 & 2.25 \\
\hline .05 & .10 & .20 & .10 & .60 & 2.00 \\
\hline .05 & .10 & .20 & .10 & .60 & 2.00 \\
\hline .05 & .10 & .20 & .10 & .60 & 2.00 \\
\hline .05 & .15 & -.25 & .15 & .70 & 2.25 \\
\hline
\end{tabular}

See our Back Cover-THE PERFECT MUSKMELON-One Packet Free. 


\section{CUCUMBER}

The cucumber seed crop, with the exception of one or two varieties, was again good last year. Be. cause our prices are lower than those of some other seedsmen, do not think our seed is not as good () n account of the uncertainty of the crop of cucumber and most other vine seeds, we always coniract for more than our actual needs, and so when we have a full crop, we can afford to make lower prices. Whe would, liowever, advise early orders. Our packets each contain 1/4 oz. of seed; sufficient to plant from 15 to 20 hills; 2 lbs. will plant one acre in hills.

Order by number. If ordered by express or freight, deduct $10 \mathrm{cts}$. per $1 \mathrm{~b}$. Half-pounds at pound rates. If larger quantities are wanted, write us for special prices.

\section{VARIETIES WE SPEGIALLY REGOMMEND.}

By Mail, postpaid.

161. CUMBERLAND. The best pickling cucumber known, also fine for 165 slicing. FARLY CYCLONE. King of the Earliest, also very productive. 157. IMPROVED CHICAGo PICKLE. Mostly used for pickies, also good for slicing. Full description below $\ldots \ldots \ldots \ldots \ldots \ldots \ldots \ldots \ldots \ldots \ldots \ldots \ldots$
$1671 / 2$. DAVIS PERFECT. Unequaled for color, shape and productive $1671 / 2$. DAVIS PERFECT

\begin{tabular}{|c|c|c|c|}
\hline kt. & $0 \%$ & $1 / 4 \mathrm{lb}$. & 16. \\
\hline & .10 & 0.2 & $\$ 0.75$ \\
\hline 0. & 10 & .20 & 65 \\
\hline .05 & .10 & .15 & .50 \\
\hline 10 & .20 & .75 & 2.50 \\
\hline
\end{tabular}

\section{CUMBERLAND.}

161. ‡ The best pickling cucum. ber known; very prolific, a shy seeder, and fine for both slicing and pickling. The Cumberland is a rapid, strong grower, producing fruit very straight and symmetrical in form (see illustration). The flesh is firm, very crisp and tender at all stages. Pkt., 5c; 0z., 10c; $1 / 4$ lb., 20c; ib., 75c.

EX. EARLY WHITE SPINE.

158. An extra fine type of what is probably the most popular variety it $\Lambda$ merica today. Unsurpassed for table use; also used for piekling; very productive. Pkt., 5 cts.; oz., 10 cts.; $1 / 4$ lb., 15 cts.; lb. 50 cts., postpaid.

$165 \frac{1}{2}$. $\star$ EARLY CYCLONE. King of the Earliest. Not only the earliest, but also rery productive and one of the most desirable of all of the White Spines, being shorter and thicker, and holding better its deep green color than any other early cucumber in cultivation. See illustration. Valuable both for slicing and for pickling. We offer strictly pure, genuine seed, froin originator. Pkt.,
cts.; $1 / 4$ lb., 20 cts.; lb., 65 cts., postpaid.

cts.; 1/4 lb., 20 cts.; lb., 65 cts., postpaid. our best White spine, is an extra select strain. 2. The cucumbers are almost cylindrical in shape, Ling i very productive: fruits dark green in color, and unequaled alike for market 5 cts.; 0z., 10 cts.; $1 / 4$ lb., 15 cts,; lb., 50 cts., postpaid.

159. ARLINGTON WHITE SPINE. A fine strain of the well-known white Spine, Large, sym-

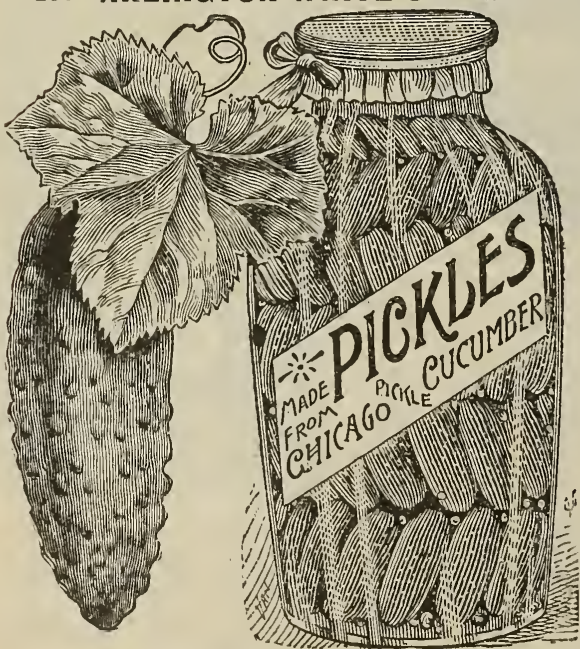
metrical and handsomest fruits. Pkt., 5 cts.; oz., 10 cts.; 1/4 lb., 15 cts.; lb., 45 cts., postpaid.

\section{IMPROVED CHIGAGO PIGKLE.}

157. $\star$ King of picklers. Used almost exclusively by the factories about Chicago. It is of medium length, pointed at both ends (see illustration); color deep green; begins to set its fruit when the vines are quite young. Also valuable for slicing, fine flavor; never overgrown and seedy. We have a choice strain of this variety. Pkt., 5 cts.; oz., 10 cts.; 1/4 lb., 15 cts.; lb., 50 cts., postpaid.

1571\%. PERFEGTED JERSEY PICKLE. A very strong der fruits which make excellent pickles. The skin is quite thin, flesh pure white, solid, crisp and tender. Pkt., 5 cts.; 0z., 10 cts.; $1 / 4$ lb., 15 cts.; lb., 50 cts. postpaid.

156. FORDHOOK PICKLING. Excenting the Cumberland, the Fordhook is one of the best and most prolific varieties for medium-sized pickles vines vigorous, healthy and productive; fruits tender, crisp, and if allowed to grow to full size, excel lent for table use. Pkt., 5 cts.; 0z., $10 \mathrm{cts} . ; 1 / 1$ lb., 15 cts.; lb., 50 cts., postpaid.

We will positively NOT SUBSTITUTE, unless given permission to do so. We will send just what is ordered or refund the money. We try to satisfy our customers, and we believe such treatment will benefit US THE MOST in the long run.

Do not fail to take advantage of our most liberal Cash Discounts. See page 45. 
CUCUMBER. WELL-KNOWN STANDARD VARIETIES.

If larger quantities are wanied than those quoted, write for special prices. Half-pounds at pound rates.

155. EARLY FRAME. An old and nost popular variety; very productive

excellent for pickles, and at maturity a good table cucumber

155 1/2. EARLY GREEN CLUSTER. A good early variety, very desirable for small pickles

160. COOL AND CRISP. Extra early, excellent for pickling or slicing;

good size, tender and crisp: very desirable.

163. IMPROVED LONG GREEN. One of the best for pickles and salad.

The seed we offer is an improved strain...

164. THORBURN'S EVERBEARING. A continuous bearer; fruit nie.

165. IIVINGSTON'S EMERALD. A grand new cucumber first-class in

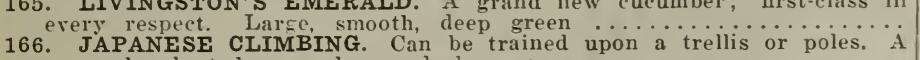

167. WEST INDIA GHERKIN, or BURR. Small prickiy fruit

169. GIANT PERA. Large, long, smooth; flesh clear, crisp and tender

$1691 / 2$. OLDS' MIXED. Cucumbers the entire season, either for pickling

or slicinc

\section{CELERY}

Celery seed is slow to germinate-sow thinly and cover lightly, and then keep constantly moist. Our packets each contain seed sufficient to produce 500 plants; $1 / 1 \mathrm{lb}$. of seed sufficient for one acre. Order by number. One pound of any variety at 3 times the cost of $1 / 41 \mathrm{~b}$.

\section{VARIETIES WE SPECIALLY RECOMMEND.}

By Mail, postpaid.

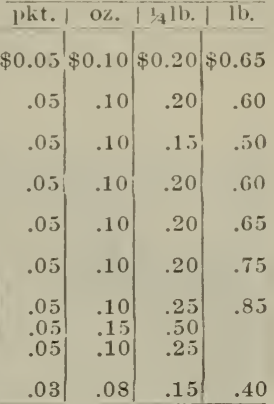

112. GOLDEN SELF-BLANCHING. The leading early variety now in all markets.

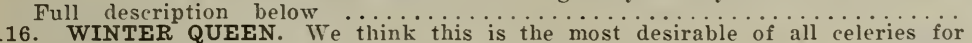

116. WINTER QUEEN. We think
winter. Full description below

117. SNOW WHITE. A free blancher and not subject to rust. See page 13

\section{$\frac{\text { Mail, postpaid. }}{\text { plit. } \text { oz. }^{1 / 4} 1 \mathrm{lb}}$}

112. $\star$ GOLDEN SELF - BLANCHING.

The leading early variety now in all markets. Stalks are broader and hearier than those of White Plume (see illustration), and much superior in quality, while it is only a little later. Our seed is a selected strain and as good as any in the market. Pkt., 5c; oz., 30c; 1/4 lb., $\$ 1.00$.

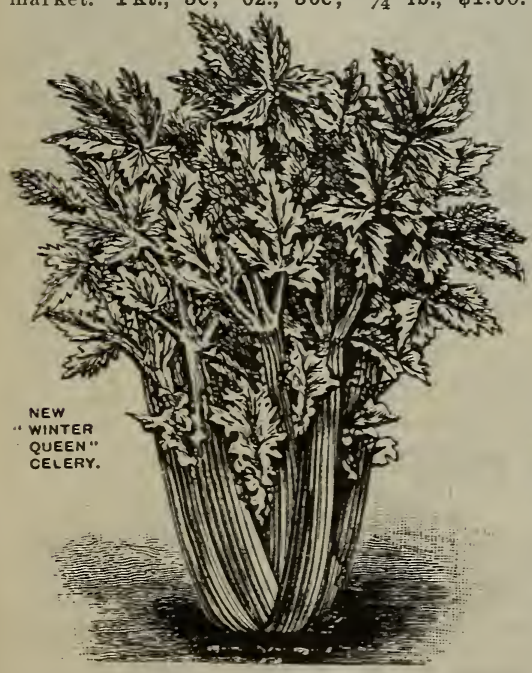

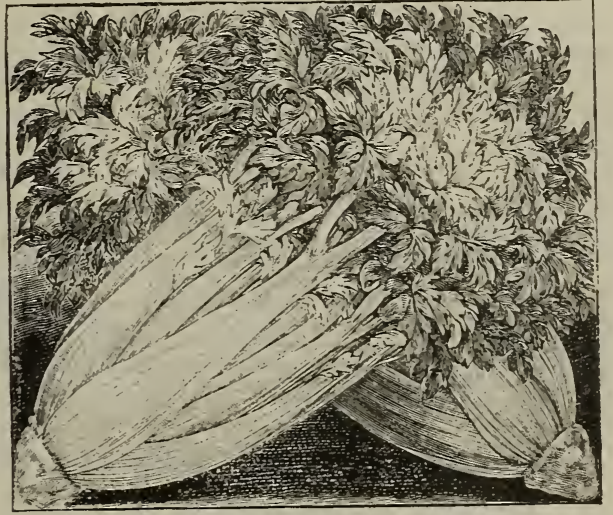

Golden Self-Blanching Celery.

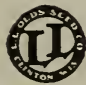

110. WHITE PLUME. Olds' Select. The earliest Celery known. A great favorite. Its stalks are naturally white, so that the work of blancliing is accomplished by simply drawing them together. It is not a good keeper, but it is an excellent sort for fall and early winter use. Pkt., 5 cts.; oz., 15 cts.; 1/4 lb., 40 cts., postpaid.

116. * WINTER QUEEN. The most desirable of all varieties of Celery for winter. It will keep late into spring; is beautiful in appearance (see illustration), of close habit and compact growth; ribs perfectly solid and crisp. This celery is worthy of a place in any garden. Pkt., 5 cts.; oz., 20 cts.; $1 / 4$ lo., 60 cts.

\section{WELL-KNOWN STANDARD VARIETIES.}

One pound of any variety at 3 times the cost of $1 / 4 \mathrm{lb}$.

111. PINK PLUME. A strong, healthy, compact grower; early, solid and crispremaining, when trenched, in good condition a long time.

113. GIANT PASCAL. Best for fall and winter use. Stalks are very large, solid 114. DWARF GOLDEN HEART. A standard variety, and largely grown for 114. DWAR

115. ROSE-RIBBED SELF-BLANCHING. A new variety unrivaled for beauty and quality-rellow, streaked with pink

118. CELERY FOR SEASONING. Good, clean seed

Mail, postpaid.

\begin{tabular}{|r|r|r}
\hline pkt. & oz. & $1 / 4 \mathrm{lb}$ \\
\hline$\$ 0.05$ & $\$ 0.15$ & $\$ 0.50$ \\
.05 & .15 & .40 \\
.05 & .10 & .35 \\
.05 & .15 & .45 \\
.05 & .10 & .20 \\
\hline
\end{tabular}




\section{CAULIFLOWER}

There is perhaps no seed that the market gardener is as particular about as Cauliflower. Good seed is always high-priced and always will be. It is the poorest kind of policy to buy poor seed of any kind, but especially so of Cauliflower. Beware of cheap seed. Our Cauliflower seed is grown in Denmark, and is the very best we can buy. No one has any better. Our packets each contain seed suffcient to produce 250 plants; from 2 to $3 \mathrm{ozs}$. of seed will furnish plants enough to transplant one acre. Order by number. Cultural directions on the back of eacli packet.

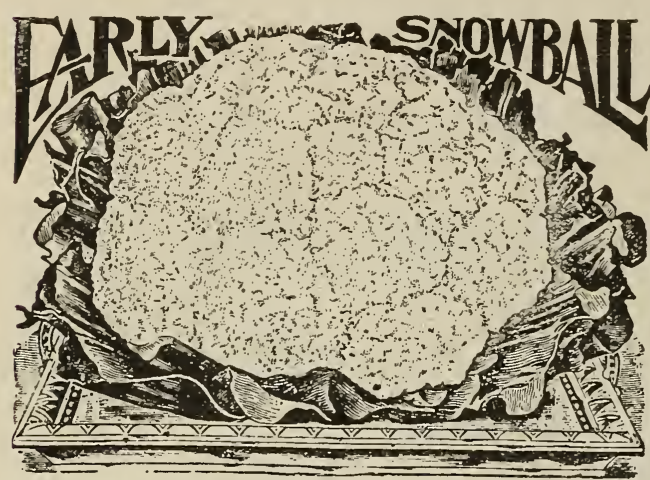

90. IMPROVED EARLY SNOWBALL. We know of no better type of this variety-
very early, smooth, rounded heads (see illus. tration), fine grained, compact and even in size. The Snowball is now the standard variety the country over. Good for either family use or market. Pkt., 10 cts.; 1/4 oz., 40 cts.; $1 / 2$ 0z., 75 cts.; oz., $\$ 1.25 ; 1 / 4$ lb., $\$ 4.50$, postpaid. Write us for special prices on larger quantities.

91. EARLY FAYORITE. This really is a fine strain of Cauliflower, but the seed costs us much less than what we pay for our Snowball. If you want a good variety at a low price, you will, male no mistake in ordering the "Fiarorite." Pkt., 5 cts.; 1/2 oz., $30 \mathrm{cts}$.; oz., 50 cts.; 1/4 lb., $\$ 1.50$, postpaid.

92. LARGE EARLY ERFURT. Best for second early, about two weeks later than Early Snowbali. Pkt., 10 cts.; 2 pkts. 15 cts.; 1/2 0z., 60 cts.; oz., $\$ 1.00 ; 1 / 4$ lb., $\$ 3.50$.

93. DRY WEATHER. See page 13. Pkt., 15 cts.; 2 pkts., 25 cts.; $1 / 4$ oz., 60 cts.; 1/2 oz., $\$ 1.00 ;$ oz., $\$ 1.50 ; 1 / 4$ lb., $\$ 5.00$, postpaid. 94. AUTUM N GIANT. The best late variety. Pkts., 5 cts.; oz., 35 cts.; $1 / 4$ 1b., $\$ 1.25$, postpaid.

\section{HERBS.}

The following medicinal herbs are so well known they need no special description. What is more healthful than Fennel, Sage or Anise tea? Also much used for flavoring; very desirable for an unused corner of the garden.

470. Anise

471. Balm

472. Caraway

474. Dill

475. Fennel, sweet

476. Horehound

477. Lavender

478. Marjoram, Sweet

479. Rosemary

480. Sage ... Plit. 5

483. Summer Savory

487. Winter savory

488. Wormwood

490. Mixed (all the above)

Pkt. 5 cts., oz, 10 cts. Pkt. 5 cts., oz. 15 cts Pkt. 5 cts., oz. $10 \mathrm{cts}$. Pkt. 5 cts., oz. 10 ets. Pkt. 5 cts., oz. 10 ets. Pkt. 5 cts., oz, 20 cts. Pkt. 5 cts., oz. 15 cts. Pkt. 5 cts.; oz. 10 cts. Pkt. 5 cts., oz. 20 cts. z. 10 ets., $1 / 4$ lb. 25 cts. Plit, 5 cts., oz, 10 cts. Pkt. 10 cts., oz. 15 cts. Pkt. 5 cts., oz. 20 cts. Pkt. 5 cts., oz. 15 cts. Pkt. 5 cts

\section{PEANUTS.}

315. MAMMOTH VIRGINIA. The largest, sweetest and most productive variety. (See illustration.) Every boy and
girl can grow their own Pea10 1 nuts here in the Nortl. DEANUTS Erect stems and upright fo-

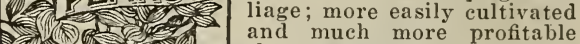
than the common spreading 50 sort. Large pkt., 5 cts. pt., 15 cts.; qt., 25 cts. postpaid. By express or freight, not prepaid: Qt., 15 . cts.; $1 / 2$ pk.,
40 cts.; pk., 75 cts.

FREE.-Any boy or gir sending us an order amounting to 50 cents or more can have a packet of these Peanuts freebe sure and ask for it when you order.
POP-CORN FOR THE BOYS AND GIRLS.

145. IMPROVED WHITE RICE. The most popular variety

146. ILLINOIS SNOWBALI. Best adapted for home use.

147. QUEEN'S GOLDEN. Largest and most productive.

148. RED BEAUTY. A new Red Rice variety. Page 13
By Mail, By Exp or Frt. postpaid. not prepaid. pkt. $\$ 0.05|\$ 0.20| \$ 0.30|| \$ 0.10 \mid \$ 0.15 \$ 0.50$

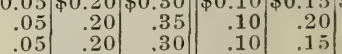

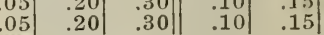

\section{A FEW MISCELLANEOUS VEGETABLES.}

\section{Order by Number.}

GOURDS. Any of the following varieties: Pkt., 5 cts.; oz., 10 cts.; 1/4 lb., 20 cts., postpaid.

180. JAPANESE NEST EGG. These resemble

hen's egg. SUGAR TROUGH. Very useful.

182. THE DIPPER. Useful.

183. HERCULES CLUB. Ornamental.

184. ORANGE. Size and shape of an orange.

\section{MIXED. All the aboye.}

170. NEW YORK IMPROVED. Very large, smooth and spineless. Pkt., 5 cts.; oz., 25 cts.; $1 / 4$ lb., 75 cts., postpaid.

175. GREEN CURLED. A refreshing salad. Can be used all through the fall and winter. Pkt. 5 cts.; oz., 10 cts.; 1/4 lb., 20 cts., postpaid.

\section{KALE OR BORECOLE.}

Pkt., 5 cts.; oz., 10 cts.; 1/4 Hb., 20 cts., postpaid. 190. DWARF GERMAN. Tery hardy, with dark green leaves; much improved by frost. 191. DWARF CURLED SCOTCH. Dwarf beaitifully curled, bright green and very hardy. 192. TALL GREEN CURLED. Tall, very fine. KOHL RABI, TURNIP CABBAGE.

Pkt., 5 cts.; oz., 10 cts.; 1/4 lb., 30 cts., postpaid. 195. EARLY WHITE VIENNA. Probably the best variety. Early and tender.

196. PUंRPLE VIENNA. A popular variety

for table use.
197 . GREEN or WHITE. Good for table use and stock feeding.

Next page-for Leeks.

QUANTITY OF SEED REQUIRED TO PLANT AN ACRE.- We find a great variation in the tables given by different seedsmen - which certainly is confusing to those seeking information. The quan tity of seed required for an acre, as given by us under each heading, is taken from our own field notes and agrees substantially with Prof. L. H. Bailey.

BLACK BEAUTY EGG PLANT-The best early market variety-See page 14. 


\section{LETTUCE}

Lettuce is in demand every month of the year, and is one of the most profitable crops grown by market gardeners. Our seed is grown by one of the most careful seed growers in California. Our packets each contain seed enough to procuce over 500 plants; $3 \mathrm{lbs}$. will seed one acre.

Order by number. One pound of any variety at three times the cost of $1 / \mathrm{ll} \mathrm{lb}$.

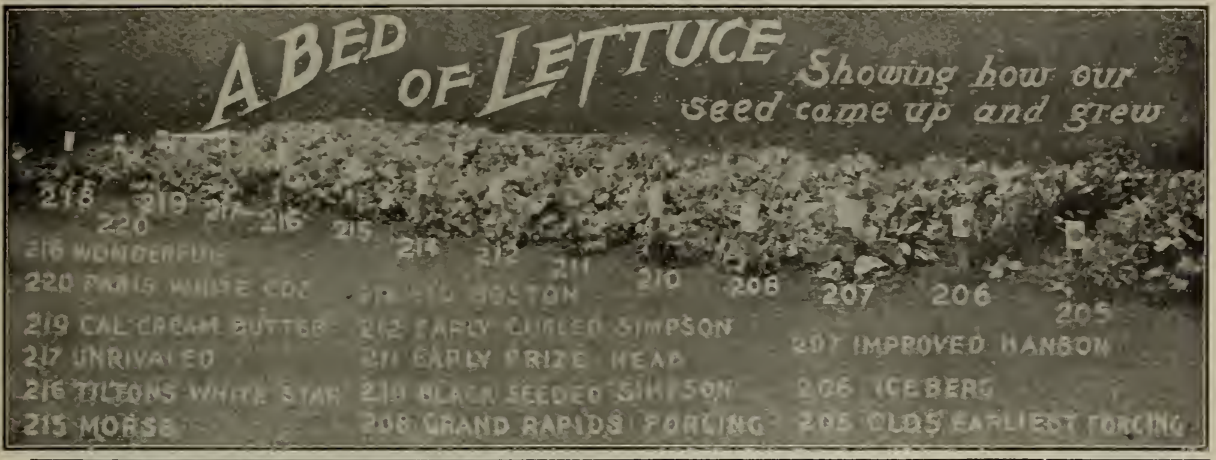

VARIETIES WE SPECIALLY RECOMMEND.

Mail, postpaid

211. EARIY PRIZE HEAD. The best all-year-round head lettuce-just right for

family use. Full description below

217. UNRIVALED. A new lettuce, combining all the qualities required by a ${ }_{\text {market gardener Full description below. }} .05$

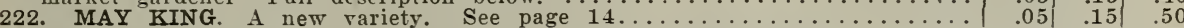

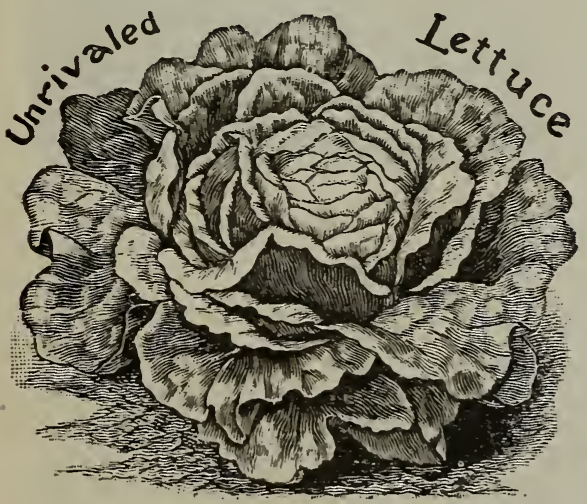

217. \ UNRIVALED. This new lettuce is just the rariety we have been looking for. It comes nearer combining all the qualities required by a market gardener than any other sort we know of. It is early, large (see illustration), attractive in color, and re. sists the summer heat. It can be sown almost the whole year round, and is crisp and solid when other lettuce is tough-try it. Pkt., 5 cts.; oz., 15 cts.; $1 / 4$ lb., 40 cts., postpaid.

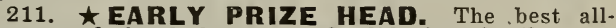
year-round head lettuce-splendid for family use. Heads large, solid, tender and of delicious flavor, remaining so throughout the season. Pkt., 5 cts.; oz., 10 cts.; 1/4 lb., 25 cts., postpaid.

At 3c per pkt., 8c per oz. and $20 \mathrm{c}$ per $1 / 4 \mathrm{lb}$., we an also furnish postpaid (except wliere noted) the following standard sorts: 206, Iceberg; 207, Improved Hanson; 209, Denver Market; 212, Early Curled Simpson; 213, Deacon or San Francisco Market; 216, Tilton's White Star; 218, Wonderful; 219, California Cream Butter; 220, Paris White Cos; 221, OAK LEAVED. Pkt., 5 cts.; oz., 15 cts.; $1 / 4$ lb., 50 cts.

OTHER GOOD VARIETIES.

One pound of any variety at 3 times the cost of $1 / 4 \mathrm{lb}$.

205. OLDS' EARLIEST FORCING (Grand Rapids). The best variety for forcing rapid upright growth crisp and tender-just right for the home garden.

210. BLACK-SEEDED SIMPSON. A popular variety-largely grown by market gardeners. Large curled leaves

214. BIG BOSTON. The best large-headed variety for forcing when full-grown. A selected strain

215. NEW MORSE. A seleted st

221. OLDS' IETTUCE MIXTURE. Salad throughout the whole season.

\section{LEEK.}

200. AMERIGAN FLAG. Most popular rariety. Leeks are raluable for soups and salads; also they may he sliced and cooked like green peas. Pkt., 5c ; oz., 10c; 1/4 lb., 25c, postpaid.

\section{MUSTARD.}

210. NEW WHITE CHINESE. Large leaves, tender, delicious and pungent. Pkt., 3c; oz., 5c; 1/4 1b., 10c; 1b., 35c, postpaid.

241. NEW MONSTROUS. A new thickleaved variety. All who have ever used mustard will like this sort. Pkt., 5c; oz., 10c; $1 / 4 \mathrm{lb}$., $15 \mathrm{c} ; 1 \mathrm{~b} ., 50 \mathrm{c}$, postpaid.

\section{MUSHROOM.}

Pure Culture Spawn. Repeated trials have dem nnstrated that the Pure Culture Spawn is far superior to spawu that is im ported; and when once used no other is wanted. It costs more than the imported, but the results show it is by far the cheaper. A brick weighs 1.3 lbs. Cultural direc tions free with every order One brick, $35 \mathrm{c} ; 3$ bricks ( 4 lbs.), $\$ 1.00$, postpaid. Not prepaid: 1 brick, $20 \mathrm{c} ; 3$ briciss, $50 \mathrm{c}$. Special prices on larger quantities.

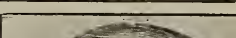




\section{MUSKMELON}

Our Muskmelon Seed is the best that can be procured and our prices are probably lower than those of some other seedsmen. With the exception of one or two varieties, we have a good crop of seed this year, and give our customers the benefit, by lower prices. Our packets each contain 1/4 oz. of seed, sufficient to plant from 15 to 20 hills; 2 to 3 lbs. will plant one acre in hills. Order by number.

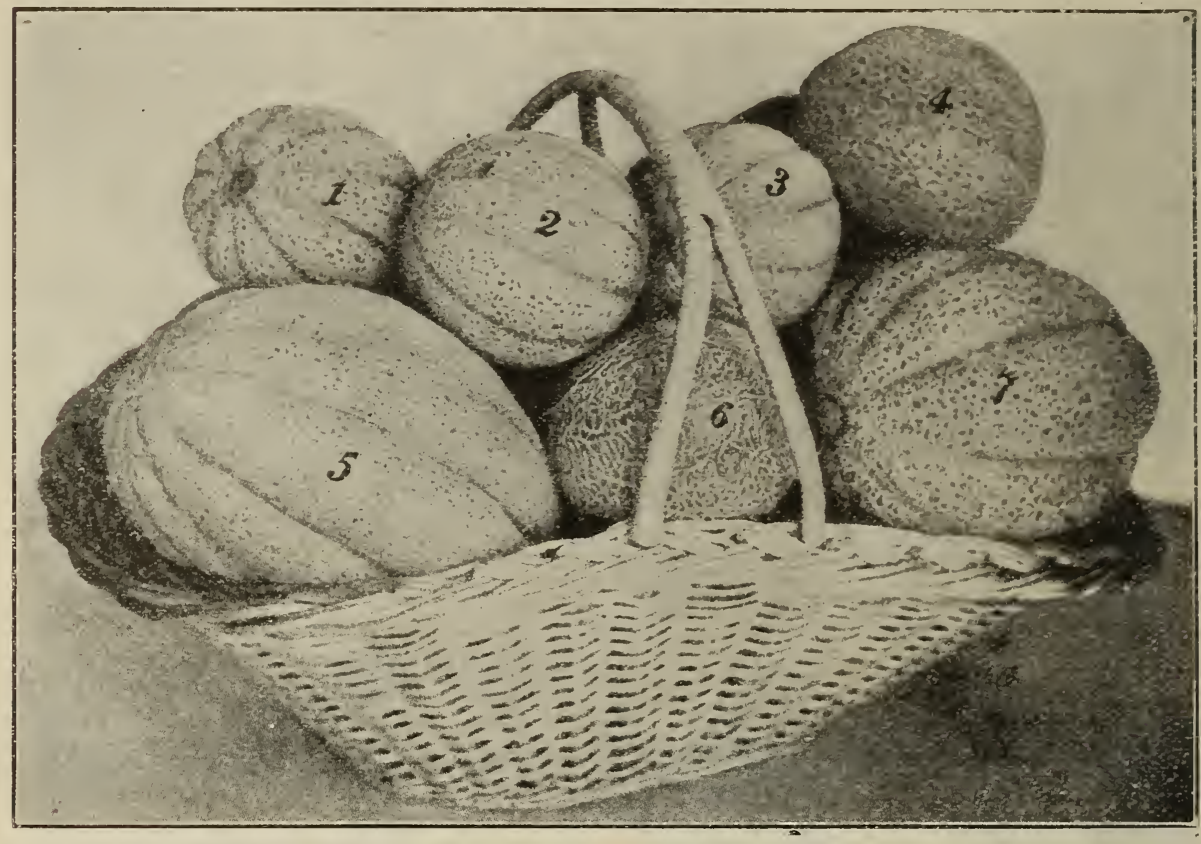

VARIETIES WE SPEGIALLY RECOMMEND.

If ordered by express or freight, deduct $10 \mathrm{cts}$. per $\mathrm{lb}$.

By Mail, postpaid.

229. OLDS' SELECT OSAGE. The most popular melon-just right for the

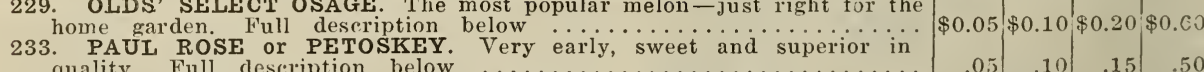
235. OLDS, FARLY MODEL. The perfect melon. See page is

\begin{tabular}{l|l|r|r}
.05 & .10 & .15 & .50 \\
.10 & .20 & .50 & 1.25
\end{tabular}

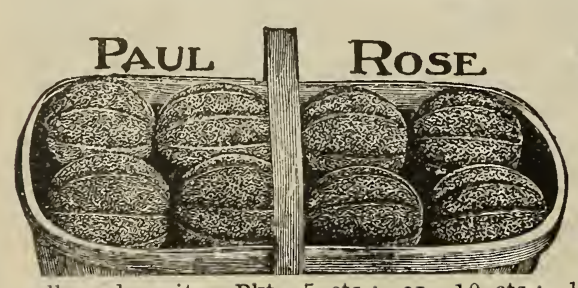

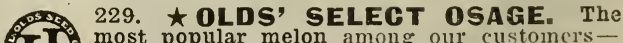
D. most popular melon among our customersis pointed oval, or egg-shaped, skin sliglitly netted, with thick, salmon-colored flesh, retaining its sweetness close to the rind. Our seed is from selected stock and low in price, because we have a large stock. Pkt., 5 cts.; oz., 10 cts.; 1/4 lb., 20

cts.: lb., 60 cts., postp2id. (1. berry.) A brand new market melon, of medium size and most excellent quality. It is an early melon, green flesh, with a small seed cavity. Pkt., 5 cts.; oz., 10 cts.; 1/4 lb., 25 cts., postpaid.

233. \ PAUL ROSE or PETOSKEY. Combines the sweetness of the Osage with the fine nettin and shipping qualities and extreme earliness of the Gem, being a cross of the two varieties. 'The melons are very uniform in shape and size (see illustration), a half-bushel basket holding 16 melons. The flesh is red or salmon colored and exceedingly sweet and highly flarored, with a very small seed cavity. Pkt., 5 cts.; oz., 10 cts.; 1/4 lb., 15 cts.; lb., 50 cts., postpaid.

\section{OTHER STANDARD VARIETIES.}

If larger quantities are wanted, write for special prices.

225. CHICAGO MARKET. (3) Early, of uniform size; green-fleshed. .

226. EXTRA EARLY HACKENSACK. Earlier and larger than the oid

227. Hackensack ' BURPEE'S NETTED GEM. (1) Early ; small, round and of fine flavor 228. EMERALD GEM. One of the sweetest melons in cultivation

230. MONTREAI NUTMEG. (7) A large, late variety, of superior quality. 231. CHAMPION MARKET. (5) As early as Netted Gem; large; prolific. 231. CHAMPION MARKET. (5) As early as Netted Gem, (6) Hardy, strong and vigorous; sweet.

234. ROCKY FORD. (2) Type of Netted Gem.

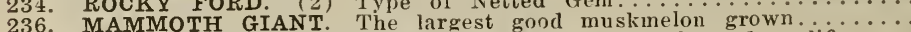

238. NEW GREEN-FLESHED OSAGE. (4) Very hardy and prolific.....

239. MANGO MELON Vegetable Orange or Vine Peach.

\begin{tabular}{|r|r|r|r}
\hline \multicolumn{4}{|c}{ By Mail, postpaid. } \\
\hline pkt. & oz. & $1 / 41 \mathrm{~b} . \mid$ & $1 \mathrm{l}$. \\
\hline$\$ 0.05$ & $\$ 0.10$ & $\$ 0.15$ & $\$ 0.50$ \\
.05 & .10 & .15 & .50 \\
.05 & .10 & .15 & .50 \\
.05 & .10 & .20 & .75 \\
.05 & .10 & .20 & .75 \\
.05 & .10 & .20 & .75 \\
.05 & .10 & & .15 \\
.05 & .10 & .15 & .50 \\
.05 & .10 & .15 & .50 \\
.05 & .10 & .20 & .75 \\
.05 & .10 & .20 & .75 \\
\hline
\end{tabular}




\section{WATERMELON}

Our Seed is saved from melons grown exclusively for seed, and by seed-growers of experience. With the exception of one or two rarieties, we have plenty of seed this year, and accordingly make our prices low. Watermelons do best on a rich, sandy soil and a warm location. Our packets each contain $1 / 4 \mathrm{Oz}$. of seed, sufficient to plant from 10 to 15 lills; 4 to $5 \mathrm{lbs}$. will plant one acre in hills.

Order by number. If ordered by express or freight, deduct $10 \mathrm{cts}$. per lb. Half-pounds at lb. rates.

\section{VARIETIES WE SPECIALLY RECOMMEND.}

247. COLE'S EARLY. A very early melon-just right in size and sliape. ICE CREAM OR PEERLESS. i stundard liome variety early and 261. ALABAMA SWEET. A new early maturing melon. Full description

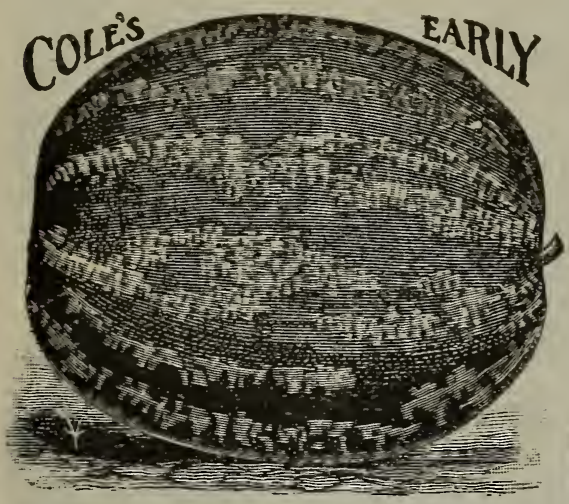

262. HALBERT HONEY. A new melon, that after a thorough trial we are satisfied is one of the finest for the home garden. It is large, attractive, oblong in shape; rind dark green; flesh crimson;
very sweet and tender. The vines grow quickly, and melons ripen even in the northern states. It is not good shipper, but it is, without doubt, as sweet as the sweetest melon yet introduced. Pkt., 5 cts.;

FREE SAMPLES FOR TRIAL. For 1908 Introduction.

We have a new Sweet Corn (rery sweet, early and productive) and a new Melon (very attractive and worth testing), which we want.our customers to try this year.

If you order anything from this catalogue, amounting to $\$ 1.00$ or more, we will gire free, on request, a packet of either of the abovestate which one you want.

We believe in halftone illustrations made from photographs. If you raise anything extra fine from our seeds, send us a good photograph of it. We will pay the cost of the photograph, and if we can do so, will use it in our next catalogue.

247. ‡ COLE'S EARLY. A fine, extra early watermelon of medium size, almost round in shape, mottled with rarious shades of green (see illustration); very sweet, tender and delicious. Pkt., 5 cts.; oz., 10 cts.; $1 / 4$ lb., 15 cts.;

lb., 50 cts., postpaid.

252. $\star$ ICE CREAM. A standard home melon. Extra early, very sweet, of good size and very productive; flesh bright scarlet, solid to the center, melting and delicious. Pkt., 5 cts.; oz., 10 cts.; $1 / 4$ lb., 15 cts.; lb., 45 cts., postpaid.

261. ^ALABAMA SWEET. A new, early-maturing melon, oblong in shape and very at tractive - see illustration. The vines are healthy and produce melons in great abundance during a long season. The color is dark green; flesh. firm and lus cious. A good shipper and a prize-winner - try it. Pkt., 5 cts.; oz., 10 cts.; 1/4 lb., 20 cts.; lb., 60 cts., postpaid.

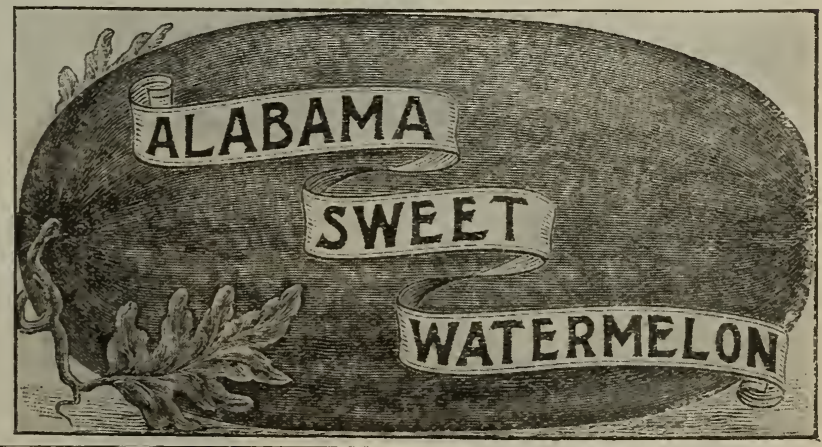

\section{OTHER GOOD VARIETIES.}

If larger quantities are wanted, write for special prices. 245. WONDERFUL SUGAR. (McIver's.) A leading melon of the day; very handsome in appearance; very productive, sweet and luscious. $\$ 0.05 \$ 0.10 \$ 0.15 \$ 0.50$ 246. SWEET HEART. The best long shipper. Large oral; flesh briglit red, solid, tender and sweet.

248. FORDHOOK EARLY. The earliest large melon a good shipper.

219. SEMINOLE. A very popular sort-one of the best.

250. KOLB'S GEM. A well-known shipper. Large and a heavy yielder: bright red flesh of very good quality.

251. DUKE JONES. An excellent shipper; flesh red, sweet and juicy

253. THE DIXIE. One of the best shipping melons grown.

254. JONES' JUMBO. Round, of large size, and of extra good quality.

255. MAMMOTH IRON CLAD. Very large and a good shipper

256. GIRARDEAU'S TRIUMPH. A variety of recent introduction; of enormous size, prolific and very sweet. A good shipper.

257. BLACK DIAMOND. A new melon-large and productive

258. KLECKLEY SWEETS. The finest melon yet introduced for home use : very handsome in appearance; flesh briglit scarlet, ripening close to the rind, crisp, melting and entirely stringless...
264. PRESERVING CITRON. Red seeded ...........

By Mail, postpaid. pkt. | oz. | 1/4lb. | lb.

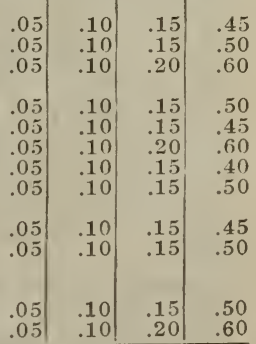
A.CASH DISCOUNT allowed on Garden and Flower Seeds-see pages 45 and 71 . 


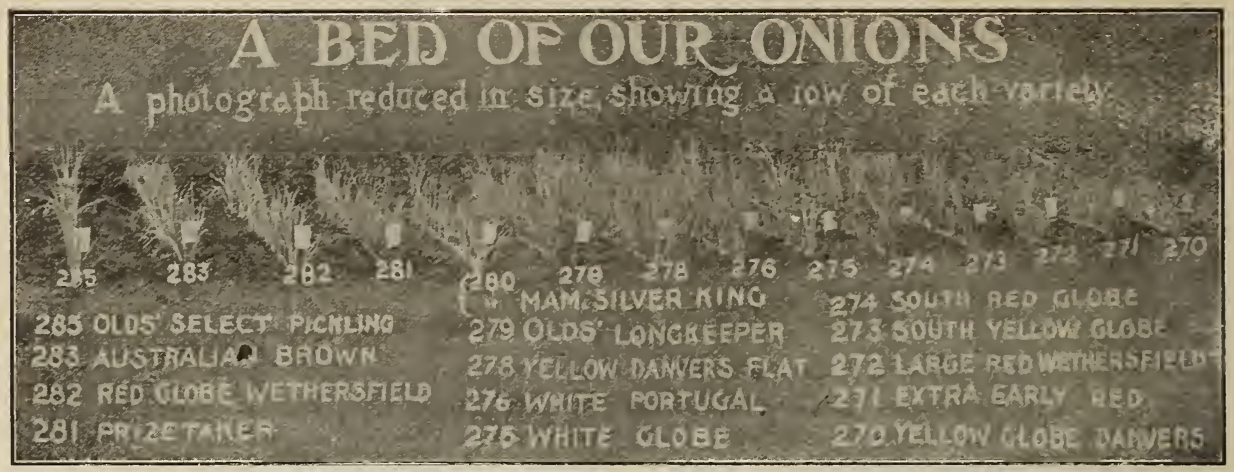

The first essential thing for success in growing fine onions is to plant strictly reliable seei. The onion seed crop was shorter last year than it has been for twenty years; consequently price.; are much higher than they have been for a long time (see foot note). Packets each contain 1-6th oz. of seed, sufficient to sow from 15 to 20 feet of drill 4 to 5 lbs. will sow one acre in drills.

272. OLDS' EXTRA LARGE RED WETHERSFIELD. The standard red onion. The skin

is deep purplish red, flesh purplish white; fine-grained and stronger flavored than any other

10 sort. It is in every respect a perfect red onion for home use and market purposes. Our strain Wes of Large Red the best that can be secured by most careful selection and cultivation. The crop is very short, and we advise early or ders. Pkt., 5c; oz., 15c; $1 / 4$ lb., $50 \mathrm{c} ;$ lb., $\$ 1.60$, postpaid. Not prepaid: 5 lbs., $\$ 7.00$.

$272 \frac{1}{2}$. Calif. Grown: Pkt., 5c; oz., $10 \mathrm{c} ; 1 / 4 \mathrm{lb}$,
$35 \mathrm{c} ;$ lb., \$1.25, postpaid.

\section{0 . $\star$ YELLO W} GLOBE DANVERS. The Yellow Globe Danvers is a standard Onion, more largely grown than any other variety. It is a large, globe-shaped onion and very productive. The skin is a light golden brown; flesh pure white, crisp and mild in flavor. The entire crop ripens down at one time and winters well. What we have here is the best strain of Yel low Globe Danvers. Seed very scarce. Pkt. $5 \mathrm{c} ;$ oz., 20c; $1 / 4$ lb., 60c; lb., $\$ 2.25$, postpaid. By express or freight, not prepaid $\$ 10.00$.

$2701 / 2$. Calif. Grown: Pkt., 5c; oz., $15 \mathrm{c}$; $1 / 4$ lb., 40c; lb., $\$ 1.50$, postpaid.

274. ^ SOUTHPORT LARGE RED GLOBE. The most handsome and perfectly globe-shaped onion in cultivation. The skin is a deep rich crimson, with a satin-like gloss flesh fine-grained, mild and very tender. The Large Red Globe is a splendid keeper, of excellent quality, and very desirable. We offer the true Southport strain.

Tellow Globe Danvers.

2741/2. California Grown: Price, same as for Yellow Globe Danvers-Calif. Grown.

273. SOUTHPORT YELLOW GLOBE. Identical with the Red Globe, except in color Our seed is the true Southport type-no better at any price. Pkt., 5c; oz., 20c; 1/4 lb. $70 \mathrm{c}$ : lb., $\$ 2.50$, postpaid.

2731/2\% California Grown: Pkt., 5c; oz. 15c; $1 / 4$ lb., 40c; lb., $\$ 1.50$, postpaid.

275. WHITE GLOBE. (Southport.) Beautiful and symmetrical, with clear, pure white skin. The flesh is firm and fine-grained. The Southport White Globe is a good keeper and a good market onion. Pkt., 5c; oz., 25c $1 / 4$ lb., 80c; lb., $\$ 2.75$, postpaid.

$2751 / 2$. California Grown: Pkt., 5c; oz.

15c; $1 / 4$ lb., 50c; lb., $\$ 1.75$, postpaid.

NOTE.-Onion seed in 1905 was a short crop, and last year the seed crop was in mauy cases almost a complete failure. New seed is bound to be high-priced this year. Our seed this year, except where noted is Eastern-grown. We find many prefer Eastern-grown onion seed to California-grownit is higher-priced and is generally considered the best to be had. 


\section{ONION SEED}

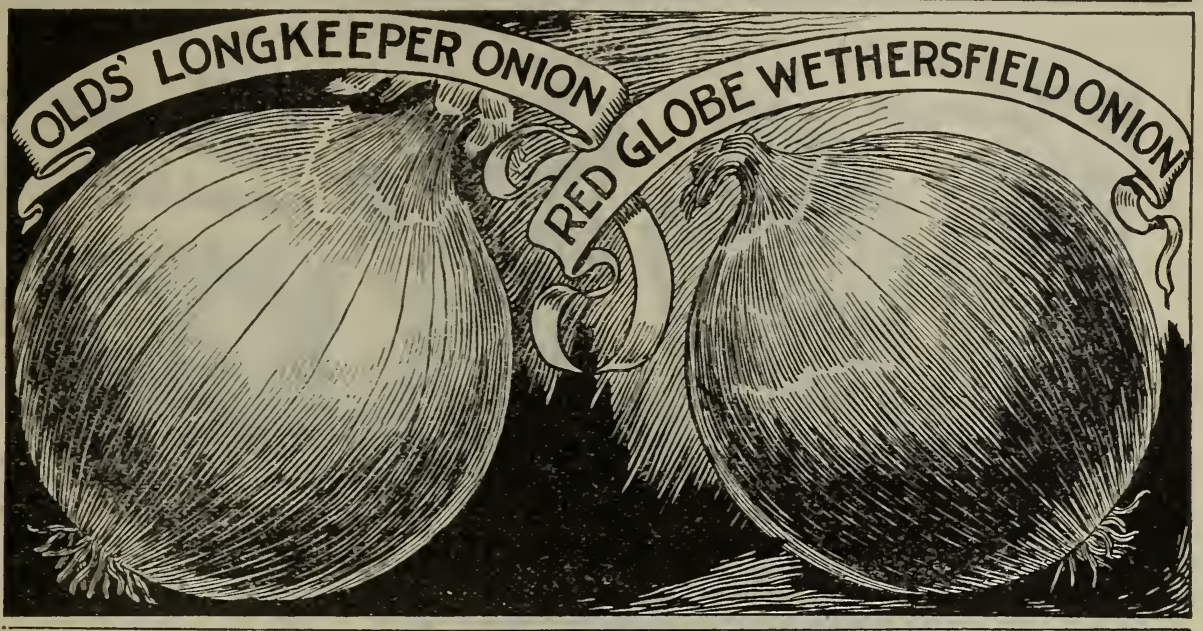

VARIETIES WE SPECIALLY RECOMMEND.

270. OLDS' YELLOW GLOBE DANVERS. The standard Yellow Globe 282. RED GLOBE WETHERSFIELD. The old reliable Large Red Wethersfield bred to a globe shape. Full description below.

274. SOUTHPORT LARGE RED GLOBE. The most handsome globe281. PRIZE-TAKER. Full description below on preceding page 281. PRIZE-TAKER. Full description below

285. OLDS' SELECT PICKLING. Full description below.

\section{(2)}

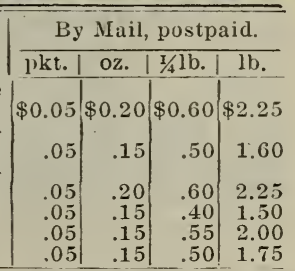

282. * RED GLOBE WETHERSFIELD. A rery handsome onion-see illustration above. The Globe Wethersfield is attractive appearance will cause it to sell at sight and bring the highest market price. Seed, a short crop. We advise early orders. Pkt., 5c; oz., $15 \mathrm{c}$; $1 / 4$ lb., $50 \mathrm{c}$; 1b., $\$ 1.60$, postpaid.

$282 \frac{1}{2}$. Catif Grown: Pkt., 5c; oz., $10 \mathrm{c} ; 1 / 4$ lb., 35c, postpaid.

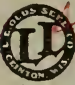
279. OLDS' LNGKEPER. A long-keeping Yellow Globe. A globe-shaped yellow onion, very quick growing and a sure cropper. The onions are perfectly globe-
shaped, uniformly thin-necked (see illustration above), with flesh pure white, solid, crisp, sweet and mild in flavor. The Longkeeper will keep in fine condition several months after harvest, and will furnish onions when prices are high. Pkt., 5c; oz., $15 \mathrm{c}$; 1/1 1b., 55c; 1b., $\$ 2.00$, postpaid.

$2791 / 2$. Calif." Grown: Pkt., 5c; oz., 15c; 1/4 lb., 40c; lb., $\$ 1.50$, postpaid.

280. MAMMOTH SILVER KING. In appearance, the most striking onion grown. Skin a beautiful silver white; flesh sweet, tender and mild in flavor. Our seed is American grown, new erop. Pkt., 5c; oz., 15c; $1 / 4$ lb., 55c; lb., \$2.00, postpaid $2801 / 2$. Calif. Grown: Pkt., $5 \mathrm{c}$; oz., $15 \mathrm{c}$; $1 / 4$ lb., $45 \mathrm{c}$; lb. $\$ 1.60$, postpaid.

281. $\star$ PRIZE-TAKER. The Genuine. A very large, handsome, yellow onion. An excel. lent keeper. American-grown seed-with only a half crop. Order early. Pkt., 5c; oz., 15c; 1/s lb., 40c; lb., $\$ 1.50$, postpaid.

$281 \frac{1}{2}$. Calif. Grown: Pkt., 5c; oz., 10c; $1 / 4$ lb., 35c; lb., $\$ 1.25$, postpaid.

286. OHIO YELLOW GLOBE. $\Lambda$ bright relloy onion, with a small neck (see illustra-

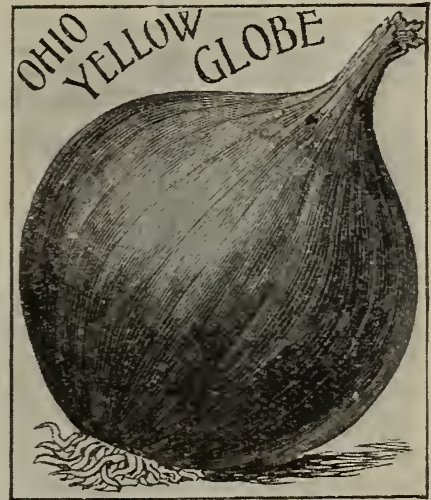

tion); ripens early and all at once; well adapted to any well-enriched soil. Pkt., 5c; oz., 20c; $1 / 4 \mathrm{lb} ., 75 \mathrm{c}$, postpaid. 285. $\star$ OLDS, SELECT PICKLING.
This select pickling onion is early, round,
hard, crisp, tender and very liandsome; $1 / 4$ lb., 55c; 1b., \$2.00, postpaid.

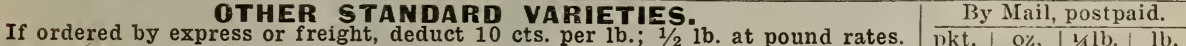

271 EXTRA EARLY RED. (Flat.) Most desirable for extra early :

closegrained, solid and heary. It is adapted to almost any soil......
WHIT PORTUGA, or Silver Skin. A favorite; Calif. grown. 27612. WHITE PORTUGAL, or Silver Skin. A farorite; Calif. grown $2831 / 2$ AUSTRALIAN BROWN. A sure cropper. Calif. grown 871 MICHIGAN YELLOW GLOBE. A heavy cropper

\begin{tabular}{|r|r|r|r}
$\$ 0.05$ & $\$ 0.10$ & $\$ 0.35$ & $\$ 1.25$ \\
.05 & .15 & .40 & 1.50 \\
.05 & .10 & .35 & 1.25 \\
.05 & .10 & .30 & 1.00 \\
.05 & .20 & .70 & 2.50 \\
\hline
\end{tabular}

At $5 \mathrm{c}$ per pkt., $10 \mathrm{c}$ per oz. $30 \mathrm{c}$ per $1 / \mathrm{lb}$ and $\$ 1.00$ per $\mathrm{lb}$, we can also furnish postpaid the following, all California Grown: 271 1/2, Extra Early Red; 2851/2, Olds' Select Pickling; 286 1/2, Ohio Yellow Giobe; $2871 / 2$, Michigan Yellow Globe.

Our California-grown Seed is crop of 1905, but shows a strong germination test. 


\section{ONION SETS}

Many prefer to grow onions from sets, as they are less trouble and are ready for use earlier than those grown from seed. Our sets this year are very nice and just the right size. One quart will plant a row 50 feet long. 10 bus. will plant one acre.

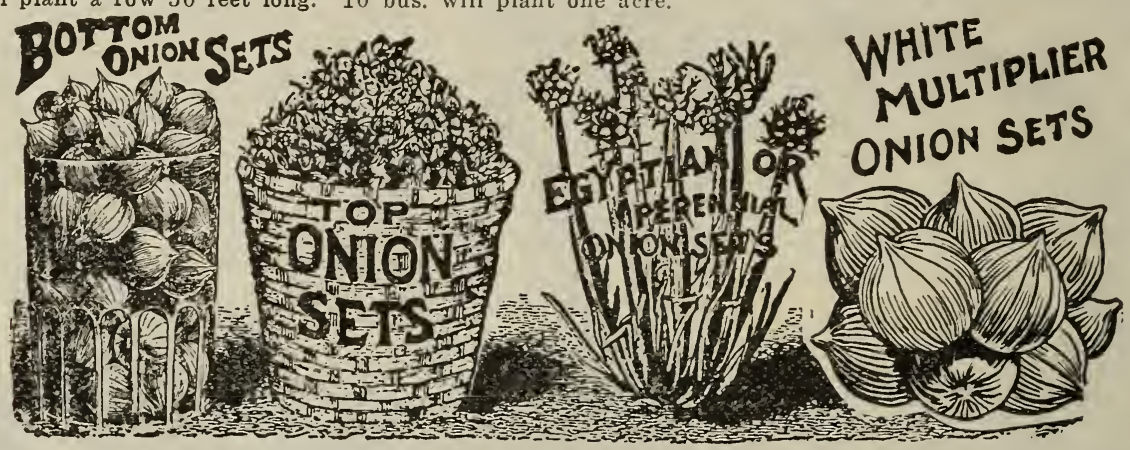

Bottom Sets are grown from seed and are the most used. Top Sets are still much called for in some sections. Egyptian or Perennial may be set either in spring or fall. They come up early in spring without any protection and furnish the earliest onions. White Multipliers are fine for buncliing green. They are enormously productive and are becoming very popular. Bottom Sets and Multipliers, bu., 32 lbs., Top Sets, bu., $28 \mathrm{lbs}$. Bushel prices are subject to market changes.

\begin{tabular}{|c|c|c|c|c|c|c|c|}
\hline \multirow{2}{*}{$\begin{array}{l}\text { VARIETIES MOST GALLED FOP. } \\
\text { If larger quantities are wanted, write for special prices. }\end{array}$} & \multicolumn{2}{|c|}{$\begin{array}{l}\text { By Mail, } \\
\text { postpaid. }\end{array}$} & \multicolumn{5}{|c|}{ By Exp. or Frt. } \\
\hline & pt. & qt. & pt. & qt. & $1 / 2 \mathrm{pk} .1$ & $\mathrm{pk}$. & bu. \\
\hline WHITE BOTTOM & $\$ 0.15$ & $\$ 0.25$ & $\$ 0.10$ & $\$ 0.15$ & $\$ 0.40$ & $\$ 0.75$ & $\$ 2$. \\
\hline YELLOW BOTTOM & .15 & .25 & .10 & $\mid .15$ & .35 & .60 & \\
\hline RED BOTTOM & .15 & .25 & .10 & .15 & .35 & .65 & 2.3 \\
\hline RED TOP (Improved) & .15 & .30 & .10 & .20 & .60 & 1.00 & 3. \\
\hline EGYPTIAN 0 & .15 & .25 & .10 & .15 & .35 & .60 & 2.00 \\
\hline WHITE MULTIPLIF & .15 & .30 & .10 & .20 & .50 & .90 & 3.25 \\
\hline
\end{tabular}

\section{PEPPER}

Our packets each contain seed sufficient to produce over 200 plants; $1 / 41 \mathrm{~b}$. of seed sufficient to transplant one acre. Order by number. One pound of any variety at 3 times the cost of $1 / 4 \mathrm{lb}$.

\section{CHINESE GIART.}

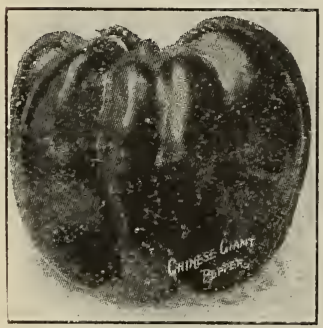

355. A new variety, and, every. thing considered, the most desirable pepper yet introduced-see illustration. Pkt., 5c; oz., $20 \mathrm{c} ; \quad 1 / \pm$ lb., $75 \mathrm{c}$, postpaid. $\mathbf{R} \mathbf{U} \mathbf{B} \mathbf{Y}$ KING. The most popular red pepper: of large size, mild and sweet. Pkt., 5c; Oz., $15 \mathrm{c} ; 1 / 4 \mathrm{lb} ., 50 \mathrm{c}$,
postpaid.

351. BELL or BULL NOSE. The best early red pepper; fine for pickling. Pkt., 5c; oz., $15 \mathrm{c} ; 1 / 4$ lb., $45 \mathrm{c}$, postpaid.

353. SWEET MOUNTAIN. Very large, productive and sweet. Pkt., 5c; oz., $15 \mathrm{c} ; 1 / 4 \mathrm{lb}$., 40c. 352. GOLDEN QUEEN. Bright golden yellow, very productive, handsome, mild and sweet. Pkt., 5c; oz., 20c; $1 / 4$ lb., 60c, postpaid.

356. RED CLUSTER. Small, coral-red; very productive. Pkt., $5 \mathrm{c}$; oz., $15 \mathrm{c}$; $1 / 4 \mathrm{lb}$., $50 \mathrm{c}$, post. paid.

354. LONG RED CAYENNE. A standard household variety-hot and pungent. Price, same as for Red Cluster.

358. MIXED PEPPERS.. All abore varieties mixed. Pkt., 5c; oz., 15c; 1/4 lb., $50 \mathrm{c}$.

\section{PARSLEY.}

One packet contains seed enough to sow a row 40 feet loug; $3 \mathrm{lbs}$, will seed one acre. Order by number. Half-pounds at pound rates. Beautifully curled and crumpled leaves-just right for seasoning; also useful for salads and garnishing. Pkt., 3cts.; 0z., 5 cts.; 1/4 lb., 10 cts.; lb.. 35 cts., postpaid.

306. FERN-LEA VED. Fern-shaped leaves: Price, same as for Cliampion Moss Curled.

\section{OKRA.}

265. WHITE VELVET. Very productive and superior in flavor and tenderness to any other variety. Pkt., 5 cts.; oz., $10 \mathrm{cts.;} \mathrm{1/4} \mathrm{lb.}$ 15 cts.; lb., 40 cts., postpaid.

We give Cultural Directions with every
Packet and Ounce. These directions are
printed on the back of each package- such
directions are always at hand when wanted,
and are better than general directions given
in the catalogue.

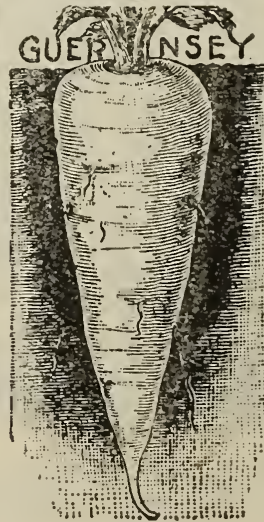

\section{PARSNIP.}

Our packets each contain seed sufficient to sow a row 30 feet long; 5 lbs. will seed 1 acre. Order by number.

\section{$310 . \quad$ IMPROVED}

GUERNSEY Te consider this the best parsnip; easily harvested. Pkt., 3c; oz., 5c; 1/4 lb., 10c; lb., 35c, postpaid. Not prepaid: 2 lbs. or more $20 \mathrm{c}$ per lb.

311 . H OL L O W CROWN. The old standard. Price, same SHORT A ROUND. An early variety, well adapted for shallow soils. Pkt., 5c; oz., 10c; $1 / 4$ lb., 15c; 1b., 40c,

See Back Cover for our new pepper-NEAPOLITAN. Pkt., 5c; oz., 20c; 1/1 1b., 75c, postpaid. 


\section{PEAS}

Of the many varieties of Garden Peas, the following comprise the best, selected as to prolonged seasoll of bearing and distinct character of growth. Our peas are grown North, are free from bugs, carefully rogued and hand-picked. Each packet contains full 2 ounces and will plant from 10 to 15 feet of drill; one quart will plant 100 feet of drill; $1 \frac{1 / 2}{2}$ to $3 \mathrm{bu}$., an acre.

Order by number. Pints, half-pecks and half-bushels at quart, peck and bushel rates, respectively, when not otherwise noted. With the exception of a few varieties, we have a good crop of peas this year. Those marked with a $(*)$ are wrinkled varietie.

\section{VARIETIES WE SPECIALLY RECOMMEND.}

320* SURPRISE. The earliest of all wrinkled peas-good326.* NOTT'S EXCELSIOR. The best early dwarf pea-rery tender and sweet. Full description below. $333 . *$ ENGIISH WONDER. We consider this the sweetest pea in cultiration today. Full description beluw.

\begin{tabular}{|r|r|r|r|r|r} 
By Mail, postpaid. & \multicolumn{3}{c|}{ By Exp. or Frt. } \\
\hline pkt. & pt. | & qt. & qt. | & pk. & bu. \\
\hline$\$ 0.05$ & $\$ 0.15$ & $\$ 0.30$ & $\$ 0.15$ & $\$ 1.00$ & $\$ 3.75$ \\
.10 & .20 & .35 & .20 & 1.25 & 4.75 \\
.10 & .20 & .35 & .20 & 1.25 & 4.50 \\
.10 & .25 & .45 & .30 & 2.00 & 7.50 \\
\hline
\end{tabular}

\section{$\frac{338 . * \text { OLDS DWARF T }}{\text { SURPRISE }}$}

320.* A new pea well named-the earliest of all wrinkled peas. The pods are good-sized and well filled. The peas are very tender and sweet, retaining their tine flavor even when fully deAlaska and the American Wonder. It possesses the quality of the latter and is as early as the earliest smooth varieties. The rines grow 24 inches high, but need no support. Pkt., 5 cts.; pt., 15 cts.; qt., or freight, not prepaid: Qt. or 1reight, not pr.; 15 i., $\$ 1.00$; bu., $\$ 3.75$.

\section{ENGLISH WONDER.}

\section{3.* The} know of. This is a new dwarf second early rariety. The pods are produced in abundance and are well filled with large, dark green peas (see illustration). It is a sure cropper. Vines
grow about 18 inches high. We highly recommend this new pea. Pkt., 10 cts.; pt., 20 cts.; qt., 35 cts., postpaid. Not prepaid: Qt., 20 cts.; pk., $\$ 1.25$; bu., $\$ 4.50$.

324.* GRADUS. The earliest large-podded pea in cultivation; pods well filled with peas of

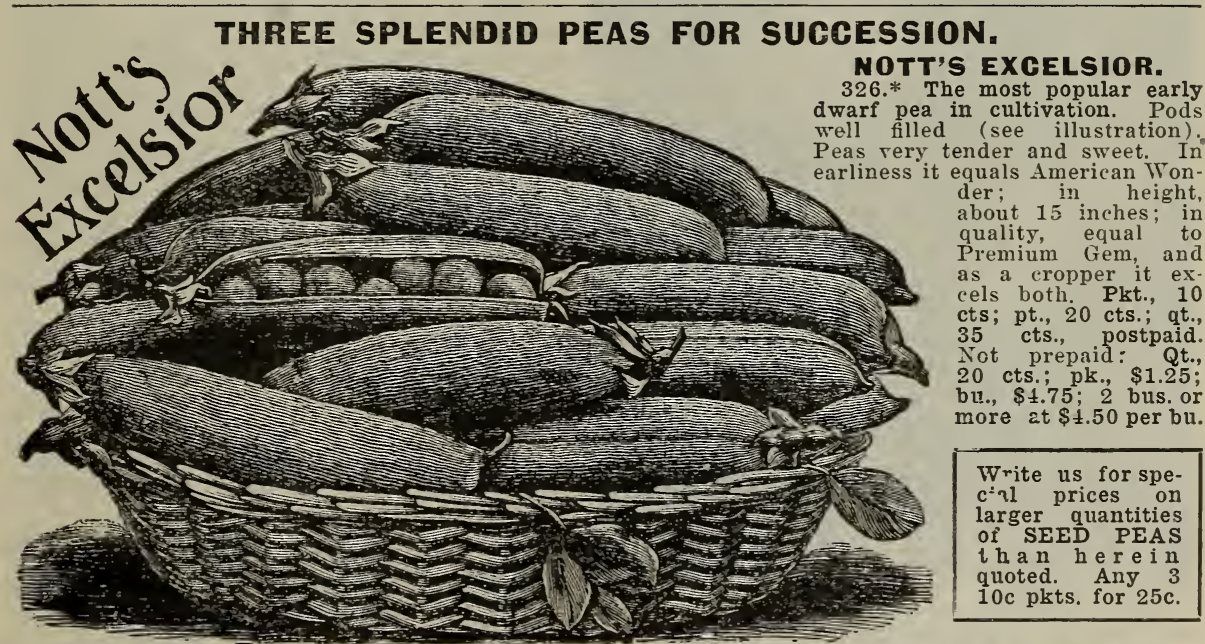

321.* THE HEROINE. Our best second early. It bears profusely and produces large pods, well filled with the rery best peas. It is a fine pea for the most critical market gardener, and we predict it will become a general-favorite. Pkt., 5 cts.; pt., 15 cts.; qt., 30 cts., postpaid. By express or freight. not prepaid: Qt., $15 \mathrm{cts}$; pk., $\$ 1.00$; bu., $\$ 3.75$.

NOTE.-Wherever you go, you will find OLDS

SEEDS GROW and are as good as THE BEST do" to please our customers. best of all the large-podded late peas; pods of 2 bus. or more at $\$ 1.50$ per bu.
327.* IMPROVED STRATAGEM. The immense size, well filled with large, dark green peas of the finest quality; height is inches-one of the very finest for a later second early. Pkt., 10 cts.; pt., 20 cts.; qt., 35 cts., postpaid. Not prepaid: Qt., 20 cts.; pk., $\$ 1.25 ;$ bu., $\$ 4.75$. fine flaror; height 3 feet. Our stock this year, for
this rariety, is a good crop, and we have reduced our prices accordingly - order early. Fkt., 10 cts.; pt., 25 cts.; qt., 40 cts., postpaid. $\$ 6.50 ; 2$ bus. or more at $\$ 6.00$ per bu. 


\section{PEAS.-Continued.}

Any $310 \mathrm{c}$ pkts. for $25 \mathrm{c}$.

\section{OTHER GOOD VARIETIES.}

Those marked with a (*) are wrinkled varieties.

323. ALASKA. The earliest of all blue peas. Very productive and of excellent quality-largely used by cauning factories. 330* AMERICAN WONDER. Dwarfest of all varieties; 12 335.* MCLEAN'S LITTLE GEM. Very prolific and a general favorite

331.* EXTRA EARLY PREMIUM GEM. A very fine dwarf pea of the Little Gem type, orer which it is an improvement: larger pods and more productive. We have a large stock.

322.* TELEPHONE. Most popular late variety; vines large; pods well filled; peas tender and of fine quality.

332.* BLISS' EVERBEARING. A very popular pea-continues bearing about two montlis. Season medium to late.

328.* CHAMPION OF ENGLAND. One of the best peas grown; a late variety; delicious and productive.

329. MELTING SUGAR. Edible pods-can be cooked and eaten, pods and all; stringless and a great improvement over the ordinary Sugar Pea

334.* THOMAS LAXTON. A cross of Gradus and Earliest of All-large pods, well filled; peas large and rich.
By Mail, postpaid. $\quad$ By Exp. or Frt. pkt. I pt. I qt. $\$ 0.05|\$ 0.15| \$ 0.30$ || $\$ 0.15 \$ 1.00 \mid \$ 3.25$ \begin{tabular}{r|r|r|r|r|r}
.10 & .20 & .35 & .20 & 1.25 & 4.50 \\
.10 & .20 & .35 & .20 & 1.25 & 4.50 \\
.10 & .20 & .35 & .20 & 1.25 & 4.00 \\
.05 & .15 & .30 & .15 & 1.00 & 3.50 \\
.05 & .15 & .30 & .15 & .85 & 3.25 \\
.05 & .10 & .25 & .10 & .75 & 2.75 \\
.10 & .20 & .35 & .20 & 1.50 & 5.00 \\
.10 & .20 & .35 & .20 & 1.50 & 5.00 \\
\hline
\end{tabular}

\section{PUMPKIN}

Some varieties are desirable for pies only, while others are profitable to grow for stock. Pumpkins are generally raised with corn, but of course do better in fields by themselves. Our seed has all been saved from pumpkins grown for seed purposes, and we have a good crop this year. Each packet contains $1 / 4 \mathrm{oz}$. of seed, sufficient to plant from 10 to 15 hills; 4 to 5 lbs. will plant one acre; one pound, one acre with corn.

Order by number. If ordered by express or freight, deduct 10 ets, per lb. Half-pounds at pound rates. If larger quantities are wanted, write for special prices.

\section{VARIETIES WE SPECIALLY RECOMMEND.}

360. KING OF MAMMOTHS. Surpasses all others for size; just right

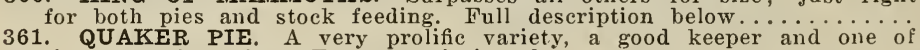
the best for pies. Full description below. ....................... 362. LARGE CONN. YELLOW FIELD. The standard field pur
sure cropper and a good keeper. Full description below.

\section{QUAKER PIE.}

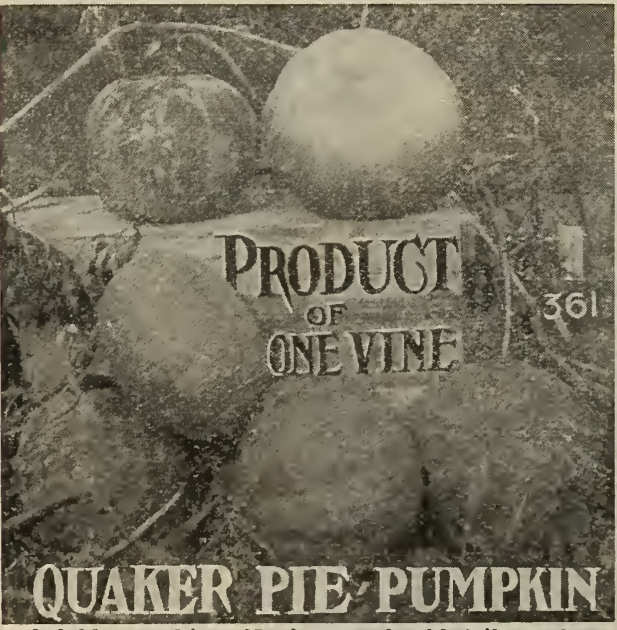

361. $\star$ A distinct variety; very prolificsee illustration, which is a photograph re duced in size, showing the product of one rine. The pumpkins are nearly round in shape; creamy white inside and out when ripe; finegrained and rich in flavor; good keepers and among the very best for pies. Until last year we never had enough seed of this variety to go around. Order early. Pkt., 5 cts.; oz., 10 cts.; 1/4 lb., 20 cts.; lb., 60 cts., postpaid.

368. GOLDEN OBLONG. A fine, new, productive variety, growing oblong in shape, Golden orange skin, thin but tough. Rich yellow flesh, very sweet, dry and excellent for pies. A good keeper. Pkt., 5 cts.; oz., 10 pts.; 1/4 lb., 15 cts.; lb., 50 cts., postpaid.

\section{KIAG OF MAMMOTHS.}

360. $\star$ Has been grown to weigh $200 \mathrm{lbs}$. surpassing any other variety for size. The flesh and skin are both bright yellow and of excellent quality. The Mammoth is one of the best pie pumpkins grown, also a splendid keeper and valuable for feeding purposes. Pkt., 5 cts.; oz., 10 cts.; 1/4 lb., 20 cts.; lb., 70 cts., postpaid.

362. \ LARGE CONN. YELLOW FIELD (Yankee Cow Pumpkin). The stand ard field pumpkin. No farmer should fail to plant this pumpkin with corn; a sure cropper, a gond 10 cts.; lb., 30 cts. postpaid. Not prepaid: 5 lbs., $90 \mathrm{cts}$.

363. SMALL SUGAR, or Yankee Pie. This is the noted New England Pie Pumpkin. Sweetest of all varieties. It resembles Large Yellow, but is much smaller-prolific, sweet and a good keeper. Pkt., 5 cts.; oz., 10 cts.; $1 / 4$ ib., 15 cts.; lb., 45 cts., postpaid.

367. LARGE' CHEESE. A fine keeper, excellent for pies, also grown in large quantities for stock. Very productive; flesh yellow and sweet. Price, same as for Small Sugar.

366. JAPANESE PIE. A new pumpkin of Japanese origin; flesh very thick, fine-grained, dry and sweet; productive and desirable for pies or cooking. Pkt., 5 cts.; oz., 10 cts.; 1/4 lb., 20 cts.; lb., 60 cts., postpaid.

365. CALHOUN. A small pie pumpkin, but of extra fine quality. Price, same as Japanese.

364. WINTER LUXURY. A new variety. pronounced by many the best pie pumpkin; o medium size. Price, same as for Japanese. If you raise anything extra fine from our seeds, send us a photograph of it-see page 59. 


\section{RADISH}

THE RADISH is one of the most profitable crops to grow for market or the private garden. It is in demand at all seasons of the year, especially in winter and early spring. Our list comprises the best varieties, and our seed is. choice French grown, from selected and transplanted roots. Pkts. contain 1/4 $\mathbf{~ o z}$. of seed, sufficient to sow from 25 to 30 feet of drill; 8 to $10 \mathrm{lbs}$, will sow one acre.

Order by number. If ordered by express or freight, deduct 10 ets. per $1 \mathrm{~b}$. Half-pounds at $1 \mathrm{~b}$. rates.

\section{VARIETIES WE SPECIALLY RECOMMEND.}

372. LOLDS' IMPROVED FRENCH BREAKFAST. Early, handsome, tender 378. CNEW LEAfLESS. Very quick growtli ; flesh white, crisp and ten 385. LWHITE ICICLE. The best long, pure white radisli: tender Full description below 374. ZeRIASON GIANT. The best new radish. See page i 7 $371 \frac{1}{2}$ IIRST AND BEST. See page 17 . $373 \frac{1}{2}$ AHITE DELICIOUS. See page 17 .
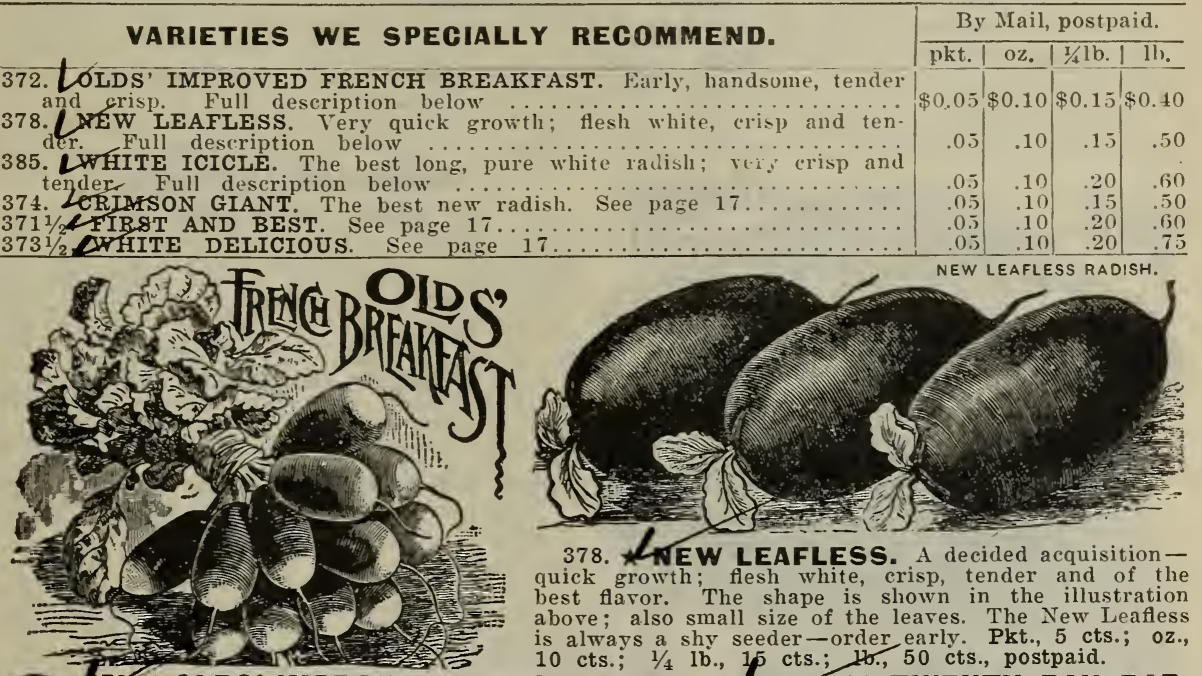

378. * NEW LEAFLESS. A decided acquisitionquick growth; flesh white, crisp, tender and of the above also small size of the leaves. The New Leafless is always a shy seeder-order early. Pkt., 5 cts.; oz., 10 cts.; $1 / 4$ lb., 15 cts.; 10., 50 cts., postpaid.

\section{8. * OLDS' IMPROVED FRENGH}

II DREAKFAST. Early, handsome, tender and crisp. Deep, glossy crimson, with the white tips well defined. We consider this radish superior to all others for forcing. Pkt., 5c; 0z., 10c; $1 / 4$ lb., 15c; lb., $40 \mathrm{c}$, postpaid.

OLDS' SNOWBALL (White Box). Earliest white turnip, forcing yurer glass, or growing in the open ground

g., 10 cts.; 1/4 lb., 15 cts.; lb., 40 cts., postpaid.
WHITE ICICLE. TRe finest pure white long variety. Roots niforif in shape, and smooth (see illustration); very early, only a few days later than the small round varieties. This radish is not only erisp and tender when young, but retains these qualities until the roots reach a large size. Pkt., 5 cts.; oz., 10 cts.; 1/4 lb., 20 cts.; lb., 60 cts., postpaid.

STANDARD AND OTHER GOOD VARIETIES.

If ordered by express or freight, deduct $10 \mathrm{c}$ per lb.

370 SCARLET TURNIP WHITE TIP. A very pop37 ylar Fariety largely grown for market. ... round, red variety

37 WHITE STRASBURG. ' $\mathrm{A}$ summer radish 37 TONG WHITE VIENNA. One of the best. 376 EARLY SCARLET GLOBE. Similar to Scaret furnip, but larger and deeper red. 38 BRIGHTEST IONG SCARLET. The most handsome long red radish

38 IIIPROVED CHARTIER. For all seasons 382 FEINA ROSE WINTER. Rose colored. 383 LINCINNATI MARKET. An early radish, 384 With omall tops - bright scarlet.......... ipg. early and globe-shaped

386 LARLY LONG SCARLET. The standard.

387 WONG BLACK SPANISH. Good keeper. 388 NAT WHITE CHINESE. The best large 388.) MIXED RADISHES.

\section{SALSIFY.}

Vegetable Oyster. There is no vegetable more rich and delicious than the Oyster Plant. Sal sify makes a rich, delicious winter vegetable, and nught to be more largely grown.

395. MAM. SANDWICH ISLAND.

largest and most profitable sort in cultivation white, smooth roots. Pkt., 5 cts.; oz., 10 cts.; $1 / 4$ lb., 20 cts.; lb., 75 cts., postpaid.

Page 15: WIS, GOLDEN SALSIFY

\begin{tabular}{|r|r|r|r}
\hline \multicolumn{4}{c}{ By Mail, postpaid. } \\
\hline pkt.| & oz. & 1/1b. & lb. \\
\hline$\$ 0.03$ & $\$ 0.05$ & $\$ 0.10$ & $\$ 0.35$ \\
.05 & .10 & .15 & .40 \\
.05 & .10 & .15 & .40 \\
.03 & .05 & .10 & .35 \\
.03 & .05 & .10 & .35 \\
.05 & .10 & .15 & .40 \\
.03 & .05 & .10 & .35 \\
.05 & .10 & .15 & .40 \\
.05 & .10 & .15 & .45 \\
.05 & .10 & .15 & .50 \\
.05 & .10 & .15 & .40 \\
.05 & .10 & .15 & .45 \\
.05 & .10 & .15 & .50 \\
.05 & .10 & .15 & \\
\hline
\end{tabular}

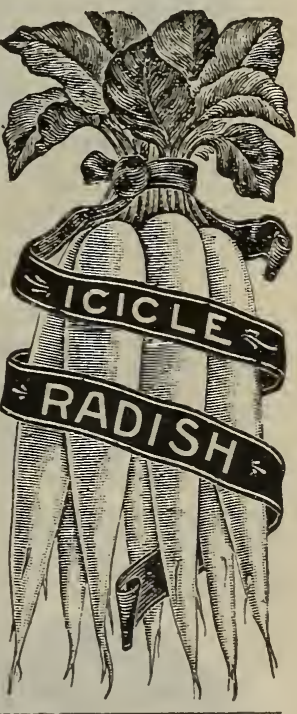

\section{RHUBARB.}

Pie Plant. Plants are easily grown from seed. 390. LARGE VIGTORIA. The standard variety, of quick growth and fine flavor. Pkt., 5 cts.; oz., 10 cts.; 1/4 lb., 30 cts., postpaid.

Wherever you go, you will find OLDS' SEEDS GROW and are as good as THE BEST and better than the rest. See Our Test, page 45 . 


\section{SQUASH}

The Squash is one of the most nutritious and valuable of all our garden vegetables-few farmers appreciate the value of winter squash as food for stock. The seed we offer is grown strictly for seed purposes. Our packets each contain $1 / 4 \mathrm{oz}$. of seed, sufficient for about 10 hills; 3 or 4 llos. of seed will plant one acre in hills. Order by number.

\section{VARIETIES WE SPEGIALLY RECOMMEND.} If ordered by express or freight, deduct $10 \mathrm{c}$ per lb. $1 / 2$ lbs. at lb. rates. $\mid$\begin{tabular}{c} 
By Mail, postpaid. \\
\hline lokt
\end{tabular} 406. GIANT SUMMER CROOKNECK. Earliest of all. Larger than com410. DELICIOUS. The thickest-meated squash yet introduced-just right

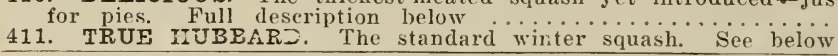

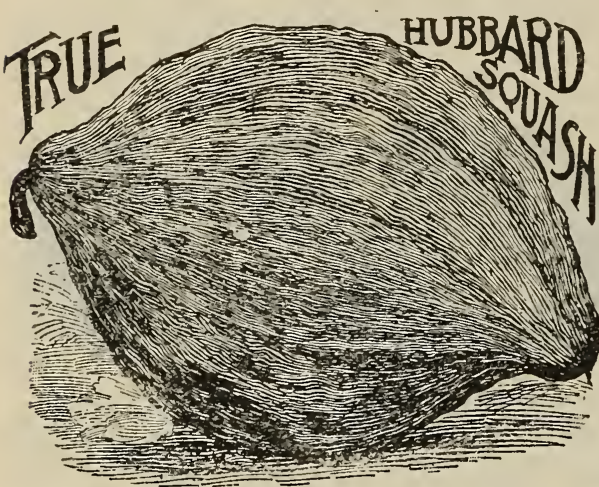

\section{HUBBARD SQUASH.}

411. ^ TRUE HUBBARD. The standard winter squash. Large, olive-shaped fruits (see illustration), with dark green skin and vêry rich flesh. Almost every one is well acquainted with Hubbard squash. Our strain is extra fine and we have a nice lot of seed this year at reasonable prices. Pkt., 5 cts.; 0z., 10 cts.; 1/4 lb., 15 cts. lb., 55 cts., postpaid. Not prepaid: 5 lbs., $\$ 2.00$.

412. WARTED HUBBARD. Similar to the above, but larger and heavily warted. Very handsome in appearance, and an excellent keeper. It has the hardest shell of all Hubbards. Price, 413. GOLDEN HUBBARD. Hearily warted like the above, with a rich orange-vellow skin, turning to a deep salmon-red when ripe. It is equally as productive and superior in quality, if anything, to the other Hubbards. We have found this to be a very desirable squash and a better keeper than any other variety. Order early. Pkt., 5 cts.; 0z., 10 ct.s.; 1/4 lb., 20 cts.; lb., 70 cts., prepaid. Not prepaid: 5 libs., $\$ 2.75$.

410. $\star$ DELIGIOUS. A recent introduction. One of the thickest-meated varieties (see illustration), and one of the best for pies. Its color is a dark flesh, a deep orange. It cooks up drier and finergrained than most other squashes, and retains these good qualities throughout the winter. We think we have enough seed this year, but order early. Pkt., 5 cts.; 0z., 10 cts.; 1/4 lb., 20 cts.; lb., 60 cts.

416. DELICATA. It is a new, early, smallfruited variety; orange color, splashed and striped with dark green. It is very solid, rich and dryextra fine for private 65 cts., postpaid. 1/4 lb., 20 cts.; lb., 65 cts., postpaid. summer Crookneck is a very old squash and almost every one is familiar with it. In the Giant Summer Crookneck we have the earliest summer squash and one much larger than the common variety. Pkt., 5 cłs.; oz., 10 cts.; 1/4 lb., 15 cts.; lb., 50c, postpaid.

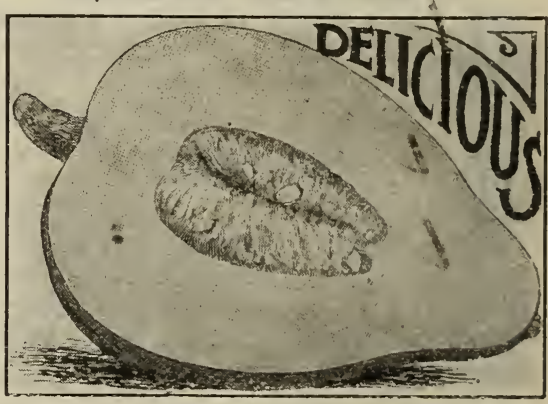

\section{STANDARD VARIETIES.}

Write us for special prices on larger quantities.

405. MAMMOTH WHITE BUSH. The best summer squash

407. FORDHOOK. Very fine for pies. A good yielder.

408. CHICAGO ORANGE MARROW. Best fall squash...........

414. GOLDEN BRONZE. A promising winter squash.

417. SIBLEY, or PIKE'S PEAK. A general favorite.

\section{SPINACH}

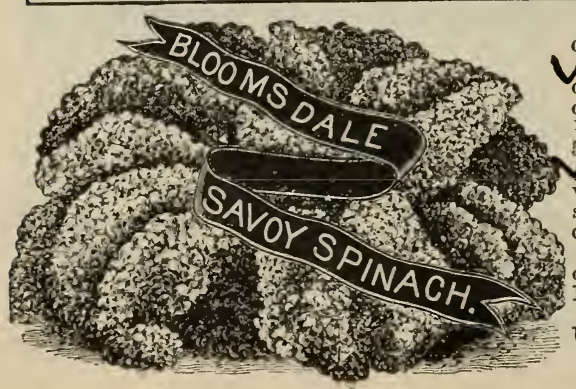

Spinach is a very important market crop. If larger quantities are wanted, write for special prices.

403. BLOOMSDALE. A great favorite; thick, ark rreen, wrinkled leaves (see illustration); liardy. of fine substance and flavor. Pkt., 3 cts.; 0z., 5 cts.; 1 lb., 10 cts.; 1b., 30 cts., postpaid. Not prepaid: lbs., 75 cts.

401. ROUND LEAVED. A well-knowr standard rariety; hardy, and especially desirable for early spring sowing. Pkt., 3 cts.; oz., 5 cts.; $1 / 4$ lb., 10
cts.; lb., 25 cts., postpaid. 42. LONG STANDING. Leaves large, thick and Price, sanie as for Round Leared.

Well-pleased Customers have made our successUnsolicited Testimonials sent on request. See page 17. 


\section{TOMATO}

BEWARE of so-called "pure cheap seed." It is folly to try to save on the first cost of Tomato Seed, when $1 / 4 \mathrm{lb}$, will plant a whole acre. Our seed is from tomatoes grown for seed, and from choice selected stocks. There are many rarieties of tomatoes and the list keeps growing longer each year. We have greatly reduced our list and offer the following varieties as, in our judgment, the best. Our Packets each contain seed sufficient to produce 150 plants; 1/4 lb. of seed is enough to transplant one acre.

Order by number. One pound of any variety at 3 times the cost of $1 / 4 \mathrm{lb}$. If ordered by express or freight, deduct $10 \mathrm{cts}$. per $1 \mathrm{~b}$.

\section{VARIETIES WE SPECIALLY RECOMMEND.}

Iail, postpaid.

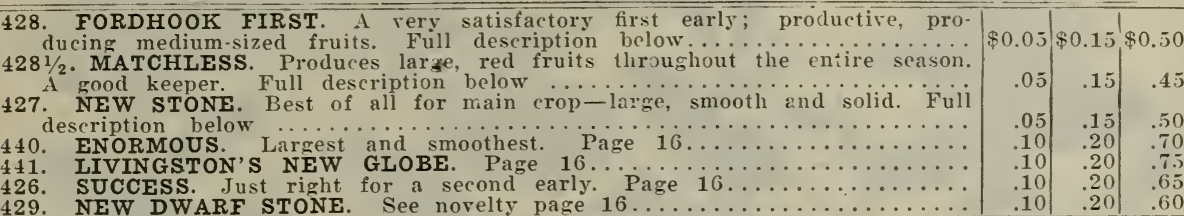

429. NEW DWARF STONE. See novelty page 16

\section{SPARK'S EARLIANA.}

425. No rariety of recent introduction has attracted more attention than this. Early tomatoes are invariably of small size, but Spark's Earliana is not only rery early, but remarkable for its large size. Handsone in shape, of a dark red color and rery firm-flesh deep red, with solid and equal to the best offered by other seedsmen. Pkt., 10 cts.; 2 pkts., 15 cts.; oz., 20 cts.; $1 / 4$ lb., 75 cts., postpaid.

\section{FORDHOOK FIRST.}

428. $\star$ We regard this rariety as a very satisfactory first early. Plants of strong growth, fruits of medium size, perfectly smooth (see illustration), and free from cracks; very handsome, productire and of the finest quality. Pkt, 5 cts.; oz., 15 cts.; 1/4 lb., 50 cts., postpaid.

436. GHALK'S EARLY JEWEL. One of the finest and most handsome early tomatoes. The fruits are large, very solid and almost round. The color is bright scarlet, and it will ripen up to the stem without any cracks or green core. The flesh is thick, solid, and with few seeds. It is productive and a good shipper. Pkt., 5 cts.; oz., 15 cts.; $1 / 4$ lb., 50 cts., postpaid.
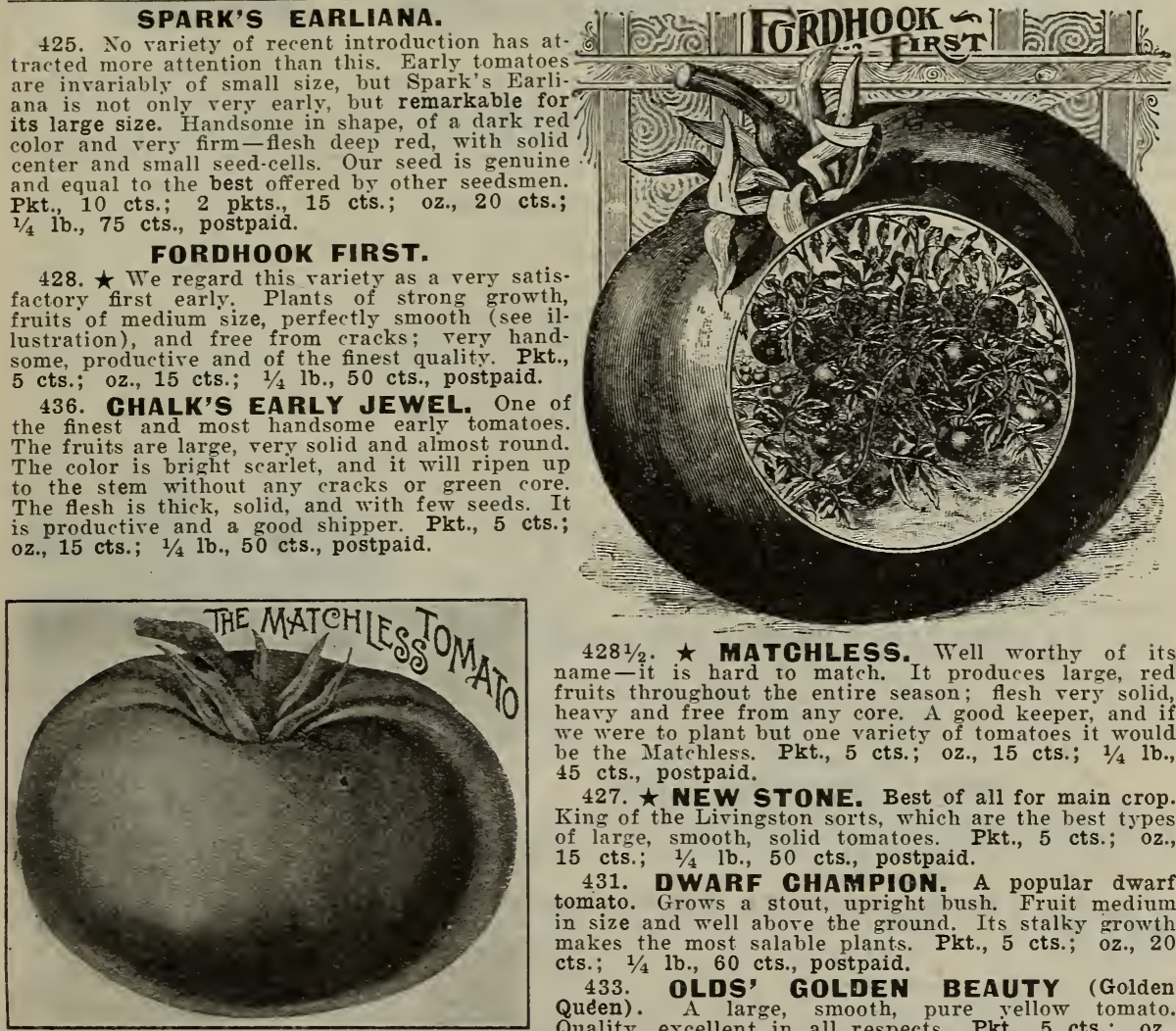

4281/2. \ MATCHLESS. Well worthy of its name-it is hard to match. It produces large, red fruits throughout the entire season; flesh very solid, heary and free from any core. A good keeper, and if we were to plant but one variety of tomatoes it would be the Matchless. Pkt., 5 cts.; oz., 15 cts.; 1/4 lb., 45 cts., postpaid.

427. ^ NEW STONE. Best of all for main crop. King of the Livingston sorts, which are the best types of large, smooth, solid tomatoes. Pkt., 5 cts.; Oz., 15 cts.; 1/4 lb., 50 cts., postpaid.

431. DWARF CHAMPION. A popular dwarf tomato. Grows a stout, upright bush. Fruit medium in size and well abore the ground. Its stalky growth makes the most salable plants. Pkt., 5 cts.; oz., 20 cts.; $1 / 4 \mathrm{lb}$., $60 \mathrm{cts}$., postpaid.

433. OLDS' GOLDEN BEAUTY (Golden Queen). A large, smooth, pure yellow tomato. Quality, excellent in all respects. Pkt., 5 cts.; oz. 15 cts.; 1/4 lb., 40 cts., postpaid.

STANDARD AND OTHER GOOD VARIETIES.

One pound at 3 times cost of $1 / 4 \mathrm{lb}$. Order by number.

430. TRUCKER'S FAVORITE. , A large, purple tomato. A great farorite

434. GREAT TALL TREE (Mansfield). Suitable for any purpose- can be readily trained to grow out of reach of chickens.

435. PONDEROSA (Henderson's). The largest of all.

437. RED TROPHY. Bright red, large and solid...

438. ATLANTIC PRIZE. Good flavored, early, smooth and solid

SMALI FRUITED VARIETIES. 445, Peach; 446, Yellow Pear; 417 , Yellow Plum; 448, Red Cherry. Each

450. STRAWBERRY or GROUND CHERRY. Husk Tomato. Fine for preserving or for pies

Fine for

\begin{tabular}{|l|} 
By Mail, postpaid. \\
\hline pkt. $|1 / 20 z$.$| oz. 1 / 1 / 4 \mathrm{lb}$
\end{tabular}

Don't miss Our MODEL COLLECTION-See back cover, EARLY BIRD COLLECTION, Page 70. 


\section{TURNIP AND RUTABAGA}

Perhaps there are no vegetables to which so little attention is given as the Turnip and Rutabaga. For feeding stock in fall or winter, there is nothing better, and we advise farmers to grow more of these remunerative crops. There are many varieties, but our list comprises the best sorts for the garden or farm. Our seed is grown on the best adapted soils, and from selected stocks. Our packets each contain $1 / 4 \mathrm{oz}$. Of seed, sufficient to sow from 30 to 40 feet of drill; $2 \mathrm{lbs}$. will sow one acre in drills; 4 lbs., broadcast.

Order by number. $2 \mathrm{lbs}$. or more at 5 -1b. rates. Write for special prices on larger quantities.

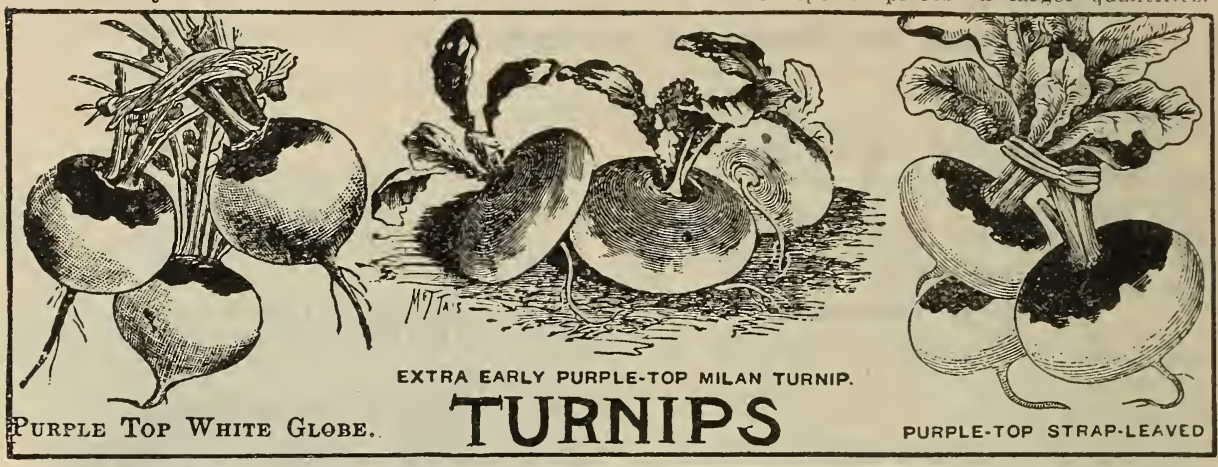

VARIETIES WE SPEGIALLY REGOMMEND.

455. PURPLE TOP STRAP LEAF. A well-known standard variety and a 456. EXTRA EARLY PURPLE TOP IMILAN. "The earliest turnip in cultivation. Flat, with a purple top. Full description below.

$\checkmark 460$. PURPLE TOP WHITE GLOBE. An early variety, globe-shaped in.

stead of flat. Full description below

$4601 / 2$. SNOWBALL. The best table turnip. Page 17 .

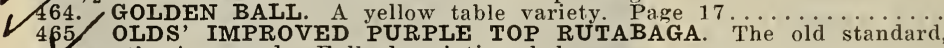

greatly improved. Full description below

\section{PURPLE TOP STRAP LEAF.}

455. $\star$ The well-known standard variety, and a great favorite for table use. Flat in shape, purple above ground, and white below (see illustration). Our seed of this variety is of the best, and we sell more of this one sort than of all the other's combined. Pkt., 3 cts.; 0z., 5 cts.; 1/4 lb., 10 cts.; lb., 35 cts., postpard. Not prepaid: 5 Ibs., $\$ 1.00$.

456. * EXTRA EARLY PURPLE TOP MILAN. A new vtrap-leaved variety - the earliest in cultivation. The bulb is flat, of medium size, quite smooth and with a purple top. The leaves are few, short, light colored and compact (see illustration). Flesh white, nard and of fine quality. It is a good keeper and a fine market and table variety. Pkt., 5 cts.; oz., 10 cts.; $1 / 4$ lb., 15 cts.; lb., 50 cts., postpaid. Not prepaid: 5 lbs., $\$ 1.75$.

\section{PURPLE TOP WHITE GLOBE}

460. $\star$ Very attractive in appearance (see illustration). It is Hapid grower, with pure white flesh. It is a sure cropper, and on account of its shape will outyield any other sort. Price, same as for Pfarple Top Strap Leaf.

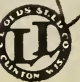

65. ` OLDS' IMPROVED PURPLE TOP RUTA. BAGA. An improved strain of the well-known standard variety. It is a heavy yielder and without tendency to rained and has a good flavor. It is has a purple top; is fine keeper and altogether very satisfactory for both table use and feeding stock. Pkt., 5 cts.; oz., 10 cts.; 1/4 lb., 15 cts.; lb., 40 cts., postpaid. Not prepaid: 5 lbs., $\$ 1.25$.

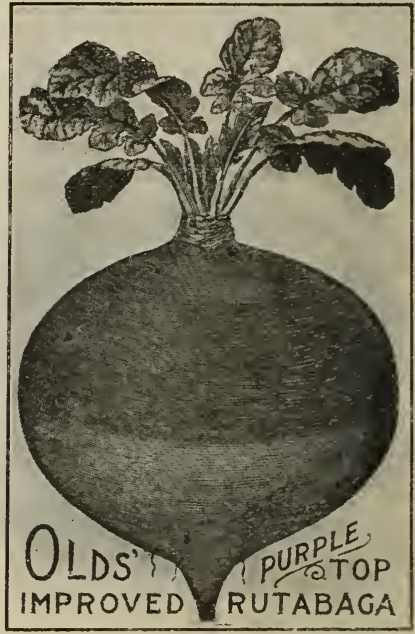

STANDARD VARIETIES.

If ordered by express or freight, deduct $10 \mathrm{c}$ per Ib. Order by number.

457. EARLY WHITE MILAN. A rapid grower and very handsome.

458. WHITE FLAT DUTCH. Flat, smooth, white, of medium size and grows quick: one of the best. 5 lbs., not prepaid, $\$ 1.25$

459. WHITE EGG. A quick grower, egg-shaped, smooth, with small top

462. COW HORN. Grows large; fine for fall or winter.

463. YELLOW ABERDEEN. The best yellow turnip for stock; tender, sweet and productive. 5 ibs., not prepaid, $\$ 1.25$

466. IMPROVED YELLOW MAMMOTH RUTABAGA Hardy of good

shape and productive. $\Lambda$ good keeper and fine for stock. 5 lbs., not pre467. WHITE RUSSIAN. 468. LAING'S IMPROVED RUTABÄGAS, each

By Mail, postpaid. \begin{tabular}{l|l|l} 
pkt.| oz. $11 / 4 \mathrm{lb} . \mid$ lh. \\
\hline
\end{tabular} $\$ 0.03 \$ 0.05 \$ 0.10 \$ 0.35$ \begin{tabular}{l|l|l|l}
.05 & .10 & .15 & .50
\end{tabular} \begin{tabular}{l|l|l|l}
.03 & .05 & .10 & .35 \\
.05 & .10 & .15 & .50 \\
.05 & .10 & .15 & .5
\end{tabular}

pkt. I oz. | 1/41b. I $1 \mathrm{~b}$. $\$ 0.05 \$ \$ 0.10 \mid \$ 0.15 \$ 0.55$

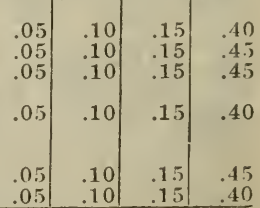
We give Cultural Directions with every packet-see page 62 . 


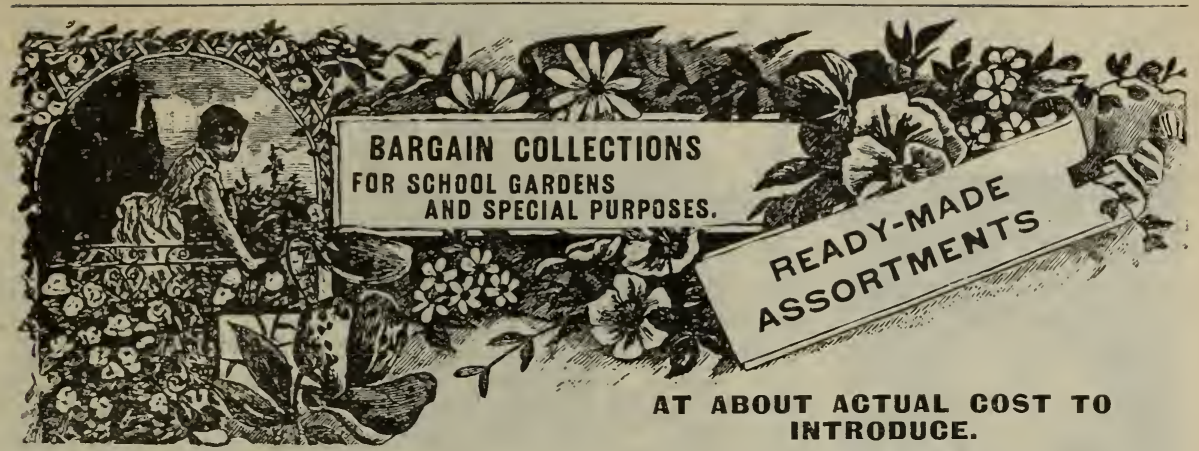

We have prepared the following collections, comprising the most desirable Vegetables and Flowers, for those who do not care to take time to make up their own selections. They have been chosen with a view to giving the table a fresh supply of vegetables and flowers throughout the whole season, and are suitable for different sized gardens. They are also just right for school gardens, and
we have made the price of each at abont actual cost. Special prices to schools wanting a number of collections.

These collections contain full-sized packets of fresh tested seed, the same as offered throughout our catalogue. They are put up before the busy season, and we cannot make any changes. Prices are
net. No discount-our discount offers on pages 45 and 71 do not apply to collections. Order by number.

\section{No. I. ANNUAL COLLECTION. $49 \mathrm{c}$ Worth for $15 \mathrm{c}$.}

This Flower Seed Collection is a great favorite-it contains 10 porular Annuals; fresh seeds. One packet each -10 packets in all- for 15 cts.: Asters 801, Balsams 850, Pinks 931, Pansies 1031, Petunias 1041, Phlox 1046, Verbena 1166, Sweet Peas 1102, Mignonette (Sweet) 1005 , and Sweet Alyssum 825 .

\section{NO: 2. CEM COLLECTION.}

This Flower Seed Collection is a beauty and hard to beat-it includes some of our best novelties in flower seeds. One packet each-12 pkts. in all-for 25 cts.: Asters 807, Carnation (Manguerite) 880, Alyssum (Little Gem) 826 Mignonette 1005, Morning Glory (Japanese) 1015 , Nasturtiums 1020 , Pansies 1030 , Petunias 1040, Phlox 1C45, Poppies 1050, Sweet Peas 1100 , and Verbenas 1165.

\section{Ho. 3. STAR COLLECTION.}

This Vegetable Seed Collection is a very pop ular one and most suitable for an early garden. One packet each -10 pkts. in all - for 25 cents : Beet 43, Cabbage 71, Cucumber 1651/2, Lettuce 205. Muskmelon (Rocky Ford) 234, Onion (Best Red Globe) 282, Parsnip (Improved Guernsey) 310 , Radish 371 , Spinach 403 , and Tomato 428

\section{4. PANSY COLLECTION.}

This Pansy Seed Collection is a dandy. It in cludes the best white, black and yellow-rich and effective colors. One packet each -5 pkts. in all-for 15 cts.: Snow Queen 1033, Black Prince 1039, Golden Gem 1035, Giant Trimar deau 1032, and President McKinley 1037.

\section{No 5 SWEET PEA COLLECTION.}

This Sweet Pea Collection is a fine one-all gilt-edged varieties, no two alike. One packet each -15 pkts. in all - for 25 cts. : Two pure whites, Blanche Burpee 1105, Emily Henderson 1106; two light colored, Lottie Eckford 1110 Stella Morse 1115: two lavenders, Countess of Radnor 1116, Dorothy Tennant 1117; two pinks, Blanche Ferry 1121, Katherine Tracy 1123; two reds, Her Majesty 1130, Salopian 1132; two blues, Captain of the Blues 1135, Emily Eckford 1137; one black, Stanley 1142; and the two cupids, White 1145 , and Pink 1146.

THE ABOVE COLLECTIONS ARE BY MAIL, POSTPAID. For descriptions and full prices, refer by numbers throughout Vegetable and Flower Seed list. See back cover for our NEW MODEL COLLECTION.

\section{To B BEST BARGAIN GOLLETIOH.}

This Vegetable seed Collection is our best bargain in vegetable seeds-no two alike. It includes our "Star" Collection-10 pkts. most suitable for an early garden, together with one packet each: Beet 49, Cabbage 79, Carrot 102, Celery 110, Sugar Corn (fine for early) 125, Sugar Corn (excellent for late) 141, Cucumber (king of picklers) 157, Lettuce (a sure header) 207, Muskmelon (Netted Gem) 227, Watermelon 246 , Onion 270, Radish 370 , Squash 413 , Tomato 427 , and Turnip 456. 25 pkts. in all for 50 cents.

\section{MO. 7. BANNER COLLEOTIOK. $\$ 1.82$ Worth for $50 \mathrm{c}$.}

This Flower Seed Collection is our best offer in flower seeds - a complete flower garden. "It includes our "Gem" Collection (some of our best novelties in flower seeds), together with some of the most select varieties from our entire list, one packet each: Asters 808, Ageratum 820, Bachelor's Button 845, Balsams 851, California Poppies 858, Calliopsis 860, CandyDianthus 932, Heliotrope 970, Hollyhocks 975 , Nasturtiums 1025, Pansies 1032, Scabiosa (Mourning Bride) 1080, Schizanthus (Butterfly Flower) 1085, Sweet Peas (best pink shades) 1151 , and Zinnias (which are always popular) 1180. 30 pkts. in all for 50 cents.

\subsection{CARDEN COLLECTION.}

This Bargain Collection is the greatest of all hargains - a complete family garden far $\$ 1.00$. It includes our "Bargain", Collection of vegetable seeds, and our "Annual" Collection of flower seeds (regular full-sized packets of our choicest Nortliern grown vegetable and flower seeds), together with a choice selection from our entire list, one packet each: Asparagus 1, Beans (the most popular bush) 13, Beans (the most popular pole) 32, Cauliflower 90, Egg Plant 170, Gourds 185, Leek 200, Lettuce 215, Watermelon 256 , Onion 281, Peas (early and productive) 323 , Peas (the best second early) 321, Parsley 305 , Pepper 350 , Pumpkin 360, Radish 385 , Salsify 395 , Squash 406, Tomato 437 , and Sage (the most useful herb) 480. At catalogue prices this collection of seeds would amount to $\$ 2.97$. Only $\$ 1.00$, by mail, postpaid, or if ordered by express or freight, not prepaid, 90 cents:

See Potato-Eye Collections, page 29.

For full list of Summer Bulbs, see page 7

Rose and other plant collections, page 79

See back cover for our NEW MODEL COL- 


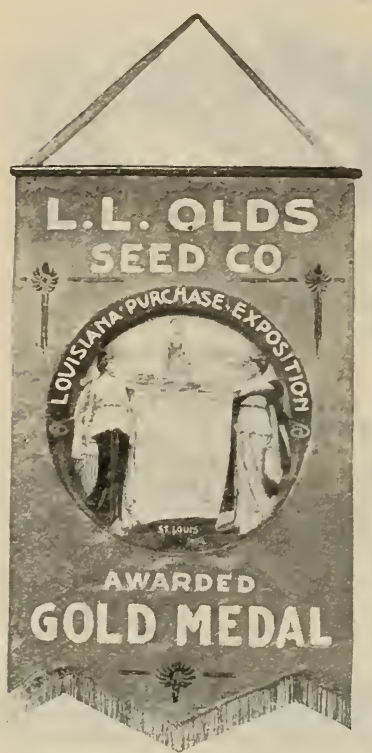

\section{EXPOSITION COLLECTION. 8 CHOICE VEgetables and 5 pOpular flowers.} 13 PACKETS FOR 25 CENTS.

The varieties in this collection of thirteen regular, full-sized packets, are fully described and in many cases illustrated in body of catalogue. One packet each-13 pkts, in all-for $25 \mathrm{cts}$.

50. BEET, New Crimson Globe (page 48). 5 cts.

70. CABBAGE, Olds' Select Jersey Wakefield (page '50) $\ldots 5$ cts.

162. CUCUMBER, Olds' Select White Spine (page 54 )...5 5 cts

205. LETTUCE, Olds' Earliest Forcing (page 57 ) . . . 5 cts.

233. MUSKMELON, Paul Rose (page 58) ........ 5 cts.

279. ONION, Olds' Longkeeper (page 61 . .............

372. RADISH, Olds' Improved Franch Breakfast (page 65 ) 5 cts.

425. TOMATO, Spark's Earliana (page 67) .......... cts

805. ASTER, White Ostrich Plume (page 72$) \ldots \ldots \ldots \ldots 10$ cts

1015. MORNING GLORY, New Japanese (page 7 i) ...... 5 cts.

1025. NASTURTIUM, Finest Tall Mixed (page 73) ... 5 cts.

1031. PANSY, Olds' Large Flowering Mixed (page 74 ) ...10 cts. 1100. SWEET PEAS, Olds' Prize Mixed (page 75$) \ldots \ldots \ldots 5$ cts

Tosal. .................. $\overline{80 \mathrm{cts}}$

With two of these collections we give free our collection of choice Pansy Seed.-See page 69

At regular catalogue prices, the above packets amount to 80 cents, but to induce all to give Olds' Seeds a trial, we offer the collection for 25 cents, by mail, postpaid; 5 collections for $\$ 1.00$. If sent by express or freight, our collection of the Best Sweet Peas (page 69) goes with every order for 5 collections. See preceding page for ther collections; back cover page for our brand new Collection "EARLY MODEL."

\section{EARLY BIRD COLLECTION.}

TEN FIRST VEGETABLES-50 CENTS, POSTPAID, WITH 25 CENTS REBATE.-See below. This collection we illustrated in colors on the back cover of our catalogue last year. It consist of ten vegetables most suitable for an Early Family Garden. One packet each-io pkts. in allfor 50 cents: TOMATO-The New Globe. Livingston's 1905 introduction - see illustration (441, page 16). BEET-Olds' Improved Blood Turnip (41, page 48). IETTUCE-New Unrivaled (217, page 57). RADISH-Crimson Giant (374, page 17). CABBAGE-Olds' Select Early Jersey Wakefield ( 70 , page 50 ). ONION - Olds' Longkeeper (279, page 61). CUCUMBER Early Cyclone, the king of the earliest $(1651 / 2$ page 54). SWEET CORN-Peep O' Day (125, page 52). BEANS - Stringless Green Pod (21 page 46). PEAS-Surprise; a new pea, well named (320, page 63)

The above are ten regular, full-sized packets, and we offer them for 50 cents, postpaid; 3 collections for $\$ 1.25$. By express or freight, $1 \mathrm{col}$ lection $40 \mathrm{cts}$. 3 for $\$ 1.00$ Each collec tion is enclosed in a coupon envelope, which when returned to us, will be accepted as a cash payment of 25 ets. on an order of $\$ 1.00$ or more.

Next year (1908) we shall introduce a new SWEET CORN (very sweet, early and productive) and a new MELON (very attractive and worth testing). We would like every one to give these a trial this year. With every order for collections or anything else amounting to $\$ 1.00$ or more, we will give free, on request, a packet of either-state which one you want.

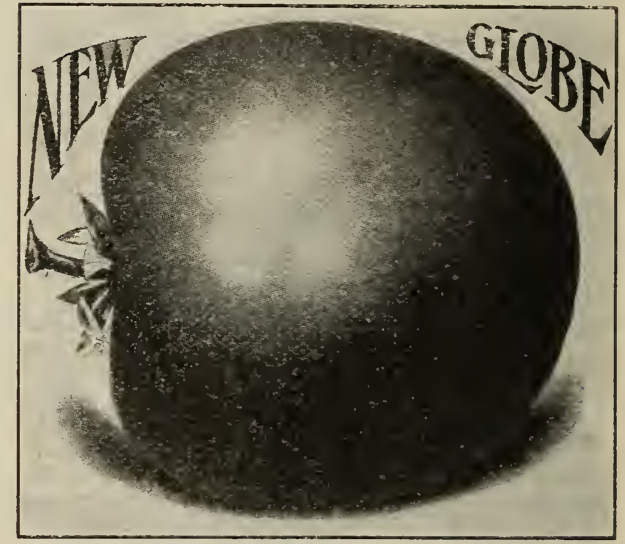

\section{BOYS' AND GIRLS' COLLECTION.}

FATHERS, GIVE THEM A SHOW-THIS COLLECTION 20 CENTS, WITH THE WHOLE AMOUNT REBATED.

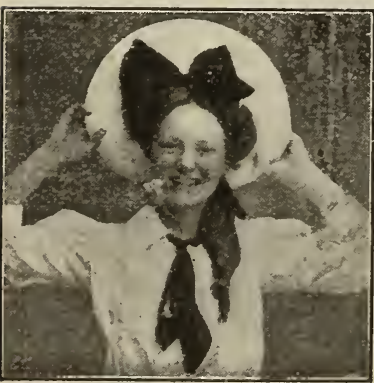

Not so many years ago we were boys ourselves, and we have boys and girls now. This collection contains full-sized packets of 8 useful vegetables and 5 flowers of easy culture. One packet each-13 pkts, in all - for 20 cents, with a rebate: Beet-The earliest blood turnip; Lettuce-Good the whole season; Radish-Grows quick, good and handsome; Spinach-Very hardy, fine flavored and orilamental; Turnip-Very productive and good for any purpose; Pop Corn-Pops like flakes of snow-large, tender and just right-see page 13: Peanuts-The largest and sweetest kind-see page 56 Muskmelon-Our New Early Model-see back cover; AstersMany colors, large and double; Dianthus-The best China Pinks; Petunia-The kind that produces large flowers; Verbena-All fine shades, and our Old-Fashioned Garden-A packet of which goes free with every order containing flower seeds - see next page.

Each collection is put in a coupon envelope, good for 20 cts. on any future order of $\$ 1.00$ or more.

Send for one or more of these collections, give the coupon envelopes to father and tell him to use them as cash in part pay. ment on his orders, paying you 20 cents each. 


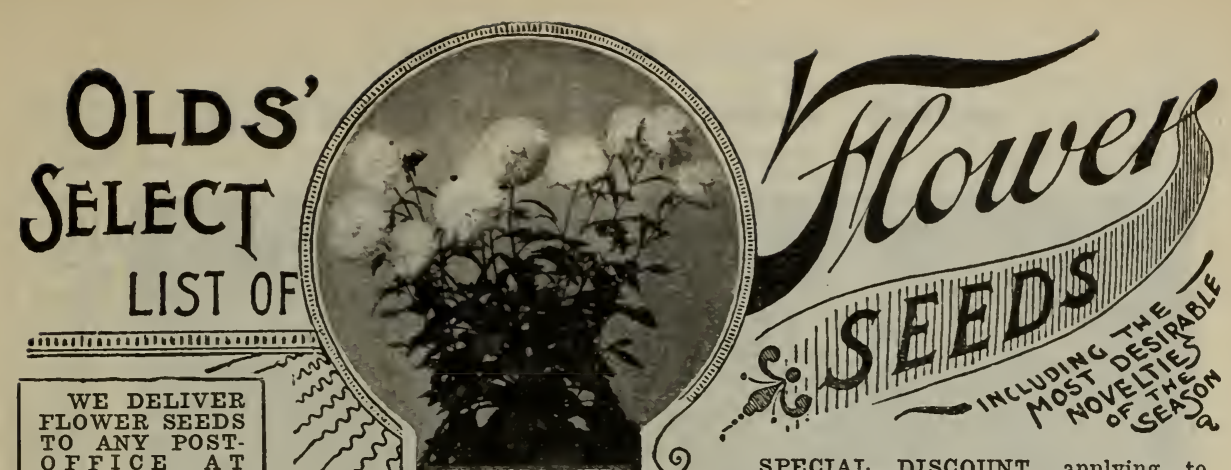
TFICT PRICES QUOTED

If ordered by express or freight select an extra 5. cent Packet.

SPECIAI DISCOUNT, applying to flower seeds by the Pkt. only. Order 50 cents' worth of Flower Seeds in packets (excepting collections-pages 69 and 70 ), and remit 35 cents -in other words, deduct 30 per cent. Our Flower Seeds are equal to the best offered anywhere. Our list has again been carefully re. rised, many new kinds added, and all inferior sorts thrown out.

We know our Flower Seeds will give satisfaction, with proper eare in sowing the seed and cultirating the plants. We will, in addition to the above liberal discount, no matter whether the order is for few or many packets, give free, on request, one liberal-sized packet of our Old-Fashioned Garden Mixture-see offer below.

Order by the number, as shown at the left of each variety. Wherever the following abbreriations occur, $A$ indicates Annual, one that grows, blooms and dies the first year from seed; $\mathbf{B}$ indicates Biennial, that blooms the second year from seed; $\mathbf{P}$ indicates Perennial, that usually blooms the second year from seed, and continues to grow and bloom sereral years-if sown early, some $\mathrm{Bi}$ ennials and Perennials will bloom the first year; $\mathbf{H}$ means Hardy, $\mathbf{H} \mathbf{H}$ means Half Hardy, and $T$ Tender-thus, H. H. A. is a Half Hardy Annual.

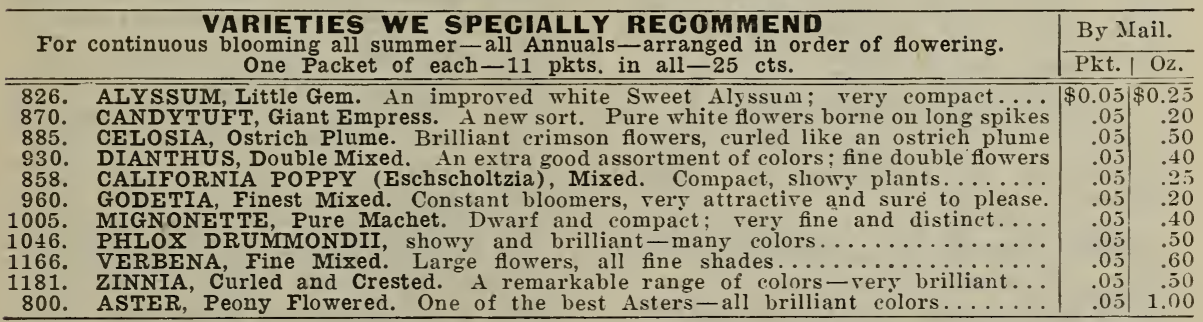

MIXED PERENNIALS

Why not have a bed of hardy perennials? It requires but little care when once established, and it will afford a succession of flowers from the earliest springtime throughout the whole season. Those who wish such a bed should order one of our large-sized ( $1 / 2$ oz.) packets of Mixed Perennials. Pkt., 10 cts.; oz., 15 cts.

\section{SPECIAL OFFER: 50 CENTS.}

If you have not the time and inclination to make your own selection and do not care for any of our collection offers, send us 50 cents and we will send you the 11 pkts. of Annuals, abore mentioned, and 50 cents' worth of other choice varieties, - sufficient seed to make your garden a blaze of bloom all summer long.

\section{OLD-FASHIONED GARDEN MIXTURE.}

For the sake of the old folks, who love the old-fashioned flowers, and for the value of the flowers themselves, we should never have a garden without some of the following: Bachelor's Button, Balsam, Candytuft, Hollyhock, Larkspur, Mignonette and others.

If you order fiower seed from this catalogue, no matter whether the order is large $00^{\circ}$ small, we will give free, on request, a liberal-sized packet of Old-Fashioned Garden Nixture as indicated abore-in addition to the other free packet offers - see pages 13, 56 and back corer.

$1029 \frac{1}{2}$. NICOTIANA SANDERAE. The New Hardy Annual. As easy to grow as a Petunia. The plants are bushy and laden with handsome carmine red blossoms; sure to be a great favorite. Plit., 10 ets.; 2 pkts., 15 cts.

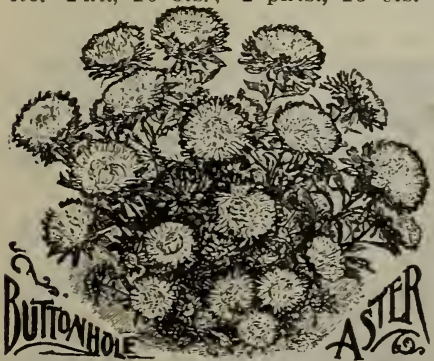

\section{NEW ASTERS.}

810. DAYBREAK. The Daybreak is of American origin and a new variety, growing about 18
inches high. The flowers are globeshaped and of a delicate pink color. Will blcom in August pkt, 5 ets. 811. GLORIA or BUTTONHOLE. This is a free blooming, branchins Aster (see ills. opposite). The plants grow about 10 inches high, with flowers $2 \frac{1 / 2}{2}$ inches in diameter. Pkt., 10 cts.; 2 pkts., 15 cts.

812. ALICE ROOSEVELT. Delicate Yellow, changing to flesh color. The flowers, when opening, are pure yellow, turning gradually to delicate flesh color-producing a very charming hue. This rare blending of colors is most desirable for cut flowers. Pkt., 10 cts.: 2 pkts., 15 cts. Other New Asters, page 18. NEW VARIETIES FLOWER SEEDS, page 18-BALANCE OF LIST, pages 72 to 76. 


\section{ASTERS. PAGKETS CONTAIN ABOUT 150 SEEDS.}

The Aster is becoming more popular every year. No plant produces a more handsome effect, and
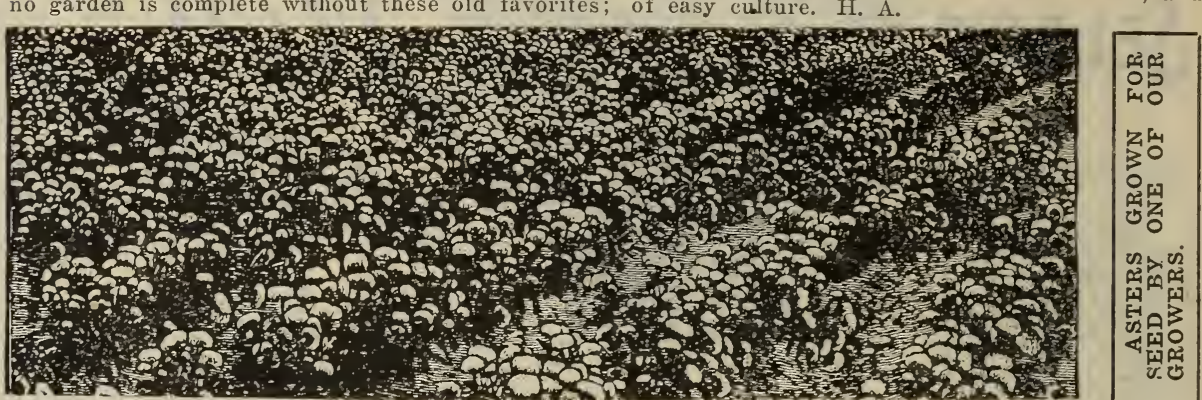

800 Peony Flowered Mixed

Plants literally covered with large, double flowers of rich, brilliant colors. Pkt., 5 cts.

801. Giant Comet Mixed. Immense double flowers, resembling chrysanthemums; many col

802 . Victoria Mixed. Very handsome. The petals curve out and down, while those of the Peony Flowered curve up and in. Pkt., 10 cts. 2 pkts., 15 cts.

803. Chrysanthemum - Flowered. Dwarf mixed; large, handsome flowers. Pkt., 5 cts. 804. Surprise Aster (Sunlight). New. Sul found in Asters. kt., 10 cts.; 2 pkts., 15 cts.

805. White Ostrich Plume. Without doubt one of the finest Asters grown. Large, graceful flowers, free from all stiffness; well adapted for cut flowers. Pkt., 5 cts.; 3 pkts., 10 cts.

ABUTILON. Chinese Bell Flower. A splendid AButin. $P$.

815. Fine Mixed. Extra fiñe. Pkt., $10 \mathrm{cts}$. AGERATUM. Floss Flower. Fine bedding

plants; valuable for borders. H. H. A.

820. Fine Mixed. Pkt., 5 cts.

ALYSSUM. A great favorite; blooming con

tinually throughout the summer. $H_{\text {. A. }}$

825. Sweet. Maritimum. White. Pkt., 3 cts.

826. Little Gem. Compact. Snow white. Pkt., 5c. AMARANTHUS. Very strong and rapid growers; ornamental foliage. H. H. A.

830. Mixed. Best sorts. Pkt., 3 cts.

ANTIRRHINUM. Snapdragon. Very showy :

blooming first season from seed. H. P.

835. Majus. Tall mixed. Pkt., 5 cts.

836. New Giant Fragrant. Mixed. Pkt., 5c. AQUILEGIA. Centaurea. Splendid for per

manent borders; of easy culture. H. P. ASPARAGUS PIANT Page 71, Pkt, $15 \%$ BACHELOR'S BUTTON. Centaurea Cyanus.

Free flowering plant; blooms until frost. H. A 845. Mixed. Very choice. Pkt., 5 ets.

BALSAMS. Pkts. contain 30 to 50 Seeds.

Balsams, like Asters, are one of our special-

ties. Our strain cannot be excelled. Large double flowers in great abundance. $H$. A.

850 Olds' Camellia Flowered Mixed

Darge, perfect, double flowers. Mixed colors. Pkt., 5 cts. Double Mixed. Pkt., 3 ets.
806. New Japanese. A very striking variety. Tassel-shaped flowers, resembling a Japanese chrysanthemum. Pkt., 5 ets.; 3 pkts., 10 ets 807. Olds' Excelsior Tall Mixed. 'A very lect mixture of the most beautiful and striking colors of the best tall sorts. Pkt., 10 cts.; pkts., 15 cts. Olds' Excelsior Dwarf Mixed.

D. very choice best dwarf varieties: most desirable colors mixed. Pkt., 10 cts.: 2 pkts. 15 c. 809. Snowball. The best divarf, white Aster. A profuse bloomer; snow-white flowers of immense size. Pkt., 5 cts.

810. Daybreak. See page 71. Pkt., 5 cts.

811. Gloria. See preceding page. Pkt., 10c.

812. Alice Roosevelt. See page 7i. Pkt., 10c.

813. Violet King. See page 18. Pkt., $15 \mathrm{c}$.

814. White Hercules. Page 18. Pkt. 10e.

CALENDULA. Pot Marigold. Profuse bloom ers all summer. $H$. A.

855. Orange King. Double, deep orange. Pkt.,3c. 856. Double Mixed. Fine shades. Pkt., 3 ets. CALIFORNIA POPPY. Eschscholtzia, Compact and bushy; fine foliage, covered with a mass of showy flowers. $H$. A

858. Fine Mixed. Many colors. Pkt., 5 cts.

CALLIOPSIS. Coreopsis. One of our best free blooming summer plants; of easy culture. H. A 860. Fine Mixed. Fine for cut flowers. Pkt., $5 c$ CANARY BIRD FLOWER. One of the most desirable climbers, producing yellow-fringed flowers throughout the whole season. H. H. A 865. Tropaeolum Canariense. Pkt., 5 ets.

CANDYTUFT. One of the most popular flow ers grown; fine for beds or edgings; of easy culture. H. A.

870. Giant Empress. A new sort. Flowers borne on long spikes. Pure white. Pkt., 5 ets.

871. Fine Mixed. All colors. Pkt., 3 ets.

872. Dwarf Hybrids Mixed. Dwarf and com pact (see illustration, preceding page). Pkt., $5 \mathrm{c}$ CANNA. Large Flowering French. A new and distinct class of Cannas of dwarf habit and producing very large flowers.

875. Crozy's Best Mixed. All the finest colors. Soak the seed twelve hours in warn water before wing. Pkt., 5 cts.; 0z., 20 cts.

CANTERBÜRY BELLS. Campanula Medium. Very handsome, rich and stately; profuse bloomers. H. B.

877. Mixed. Best and most striking single and double varieties. Pkt., 5 cts.

\section{Garnations.}

FROM SEED.

Carnations are ve ry much admired for their beauty and fragrance: will bloom in about four months after sowing - seed sown in the fall, slightly protected over winter, will produce plants in full bloom early in the spring. H. IT. P.

880. Marguerite. New Giant (see ills, opposite) producing large flowers of producing large fowers of 2 pkts., 15 cts.

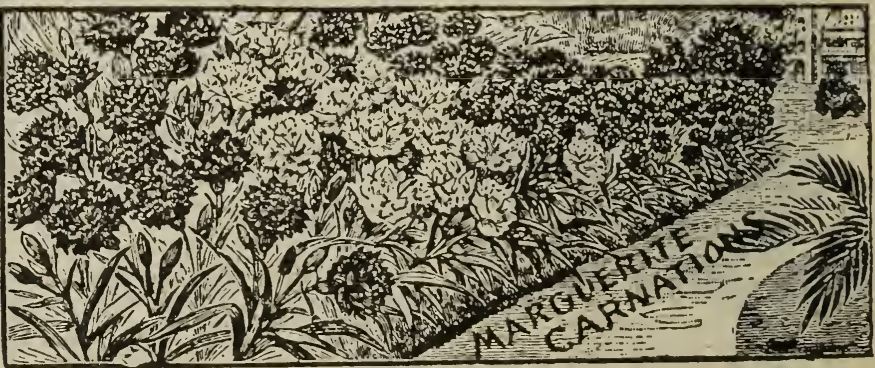
30 PER CENT CASH DISCOUNT on Flower Seed by the Packet-see preceding page. 
OLDS’ SELECT NASTURTIUMS. Dwarf, Tall and Climbing.

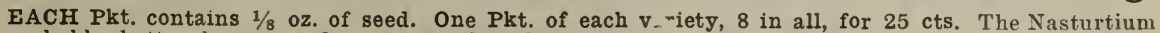
is probably better. known and more popular than any other flower grown-no garden is complete without it. One of our specialties, and our seed cannot be surpassed.

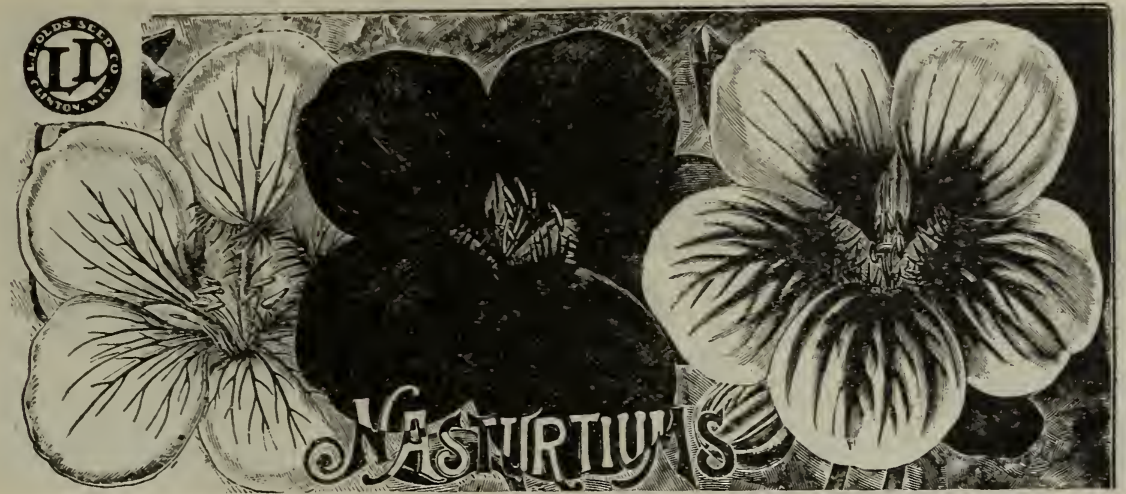

DWARF NASTURTIUMS.

Dwarf or Tom Thumb varieties are unrivaled in beauty. They bloom profusely and are well adapted to poor soil. One pkt. of each for $15 \mathrm{c}$. 1020. Dwarf Mixed. All choice colors. Pkt., 3 cts.; oz., 8 cts.; $1 / 4$ lb., 20 cts.

1021. Empress of India. Deep crimson, dark leaved. Pkt. 5 cts. oz, 20 ets.

1022. Ladybird. Golden yellow, barred with crimson. Pkt., 5 cts.; oz., 20 cts.

1023. Chameleon. 'Dwarf French, variegated colors. Pkt., 5 cts.; oz., 20 ets.

One lb. Nasturtiums at 3 times cost of $1 / 4 \mathrm{lb}$.; $1 / 4 \mathrm{lb}$. when not otherwise mentioned, 3 times cost of $1 \mathrm{oz}$. Not postpaid, $10 \mathrm{cts}$. per lb. less.

CELOSIA. Cockscomb. Plume-shaped flowers. 885. Ostrich Plume. Crimson flowers, curled like an ostrich plume. Pkt., 5 ets.

886. Fine Mixed. The best tall sorts. Pkt., 3c. CENTAUREA. Profuse bloomers, suitable for bouauets and general floral decoration. H. A. 890. Margaret. Pure white flowers. Pkt., 5c. 891. Imperialis. A new, sweet-scented Cenaurea: very showy. Pkt, 5 cts.

CHRYSANTHEMUM. Blooming continually all summer; suitable for pot culture. H. A.

895. Mixed. Single and double. Pkt., 5 ets. 896. Golden Ball. An annual variety and a very free bloomer. Pkt., 5 cts.

COBAEA SCANDENS. One of our finest summer climbers, fine foliage; large, bell-shaped flowers. H. H. P.

900. Purple. A rery rapid grower. Pkt., 5c. Cosmos. A very handsome flower, becoming more popular every year. One of the last flowers to bloom in the fall; fine for rases. H. H. A. 905. Early Dwarf Dawn. A new rariety. Blooming in.July and until frost. Pkt., 5 cts. 906. Early Hybridus Mixed. Pkt., 3 ets.

CYPRESS VINE. A rery beautiful climber with delicate dark green leaves and star-shaped flowers. T. A. Height about 15 feet.

910. Mixed. Rose, scarlet and white. Pkt., 5c. 912. Ivy Leaved. A new scarlet variety. with ivy-shaped leares. Pkt., 5 cts.

DAHLIAS. From seed; blooming the first seasin. H. H. P. Dahlia Bulbs, page 77 .

915. Double Mixed. Large fowering. Pkt.,

916. Superb Single. Nixed colors. Plit., 3c.

\section{DOUBLE DAISIES.}

One of the most charming early spring flowers: very easily raised from seed. H. I1. P. 920. Fine Mixed. All colors. Pkt., 5 ets. 921. Shasta. A new sort, with very large, graceful flowers. Pkt., 10 ets.

922 . New Snowball. Very large and double.

Pure white. Pkt., 10 cts.: 2 pkts. 15 cts.

DATURA. Showy trumpet-shaped flowers. H.A 925. Cornucopia. Horn of Plenty. Pkt., 5c. DOLICHOS. Hyacinth Bean. A rapid growing climber; pea-shaped blossoms.

935. Mixed. Plit., 5 cts.

\section{TALL NASTURTIUMS.}

The tall varieties are suitable for trellis, porch or veranda decorations, and no flower is more attractive or brighter than these.

1025. Tall Mixed. The finest assortment. Pkt., 3 cts.; oz., 8 cts.; $1 / 4$ lb., $18 \mathrm{cts}$.
1026. Madam Gunther's Hybrids. A new sort, very choice. Pkt., 5 cts.; oz., 20 cts.

CLIMBING NASTURTIUMS.

Flowers are borne in great profusion.

1028. Lobbs' Mixed. Pkt., 5 cts.; oz., 20 cts.

1029. Ivy Leaved. A new, distinc', showy climbing variety; iry-shaped leares. Pkt., 5 cts.; oz., 25 cts.

\section{DIANTHUS. CHINESE PINKS.}

One of the most bountiful bloomers the garden can contain; blooming the first summer and also the second if protected over winter. H. B.

930. Double Mixed. Extra choice. Pkt., 5 cts.

931. Imperialis fl. pl. Mixed colors. Pkt., 3e.

932. Single Mixed. Extra fine. Pkt., 5 ets.

933. The Bride. Compact dwarf plants; pure

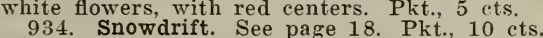

EVERLASTING FLOWERS. Beautiful flowers of a great variety of color. H. A.

940. Helichrysum. Very fine. Pkt., 5 cts.

FORGET-ME-NOT. Myosotis. Everybody's favorite. Star-like flowers. Blooming first year from seed, if sown early. T. H.

945. Mixed. Many colors. Pkt., 3 ets.

FOUR O'CLOCK. Narvel of Peru. H. A

950. Fine Mixed. Pkt., 3 cts.

FUCHSIA (from seed). This well-known plant can easily be grown from seed.

953. Double Mixeá. Pkt., 15c; 2 pkts, $25 \mathrm{c}$

GAILLARDIA. Blanket Flower. Tery desirable for masses, borders and for cutting. H.H.A. 955. Double Mixed. Round as a ball. Pkt., 3e. GODETIA. Constant bloomers, rery attractive, and well adapted to any soil. H. A.

960. Finest Mixed. Sure to please. Pkt., 5c. GOURDS. Ornametital. Also useful as well as ornamental. T. A. See page 56 for named sorts. 965. Mixed. Many sorts. Pkt., 5 cts.

HELIOTROPE. From seed the first year. Produces delicate blue and white flowers the entire season; very fragrant. H. H. P.

970. Choice Mixed. Pkt., over 500 seeds, HOLLYHOCK. A perennial. Seed sown in June or July will produce plants that will bloom early the next summer. H. P.

975. Double Mixed. Producing the largest and finest double flowers. The best colors. Pkt., 5c. HUMULUS. Japanese Hop. A rapid growing limber, with luxuriant foliage. H. A.
980 . Japonicus. Withstands heat, drought nd insects. Pkt. of over 50 seeds, 5 cts.

LATHRYUS. Everlasting Peas. Very attractive. 990. Litifolius Mixed. Pkt., 5 ets. 


\section{OLDS' GIANT PRIZE and Other PANSIES.}

Finest Selection of Pansies that can be found anywhere. Choice Pansy Seed is our greatest spe. cialty in Flower Seeds - nothing is more inportant in our select list, and we have spared no trouble or expense to have the very best. Our Packets contain about 150 seeds each.

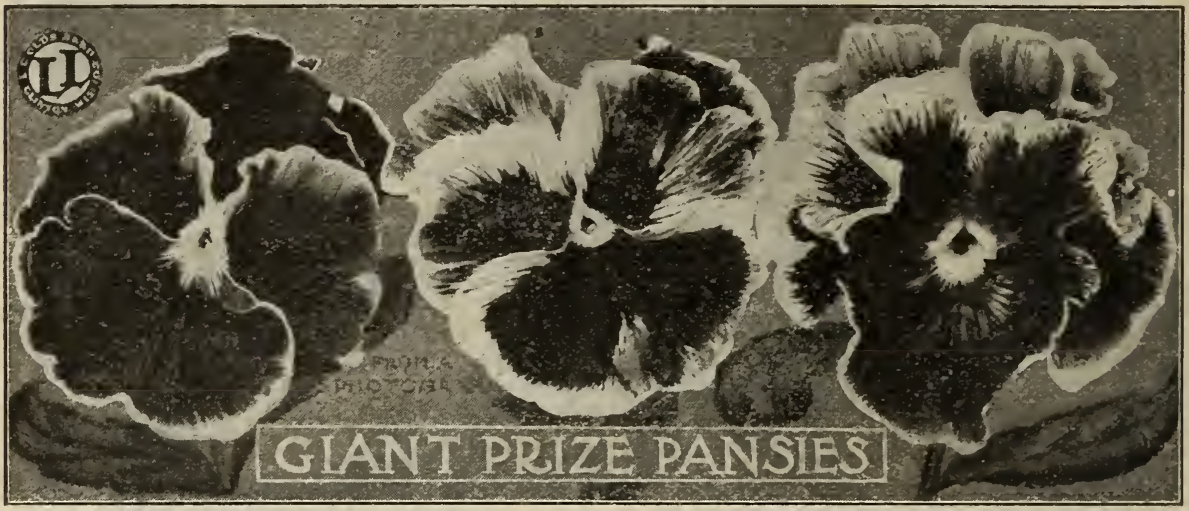

10301/2, OLDS' GIANT PRIZE MIXED. This seed produces the largest, richest and best formed flowers of any we have ever offered, and we believe, from our own trials, there is no better pansy mixture to be had anywhere or at any price-see illustration from a photograph. Pkt., 20 cts.; 3 pkts., 50 cts.

1030. INTERNATIONAI MIXED. A very fine mixture of pansy seed, gathered from all nations; saved from named exhibition flowers. The usual price of this mixture is 25 cents per pkt. Pkt., 15 cts.; 2 pkts., 25 cts.

1031. OLDS' LARGE FLOWERING. A superb mixture, producing large flowers, of a great variety of charming colors - the best German varieties mixed. Pkt., 10 cts.; 3 pkts., 25 cts.

Any one sending us the names of ten prospective buyers can have a packet of No. 1031 free in addition to their order-please mention it when ordering. This is in addition to any other offer.

1032. GIANT TRIMARDEAU MIXED. Large flowers: rich and varied shades. Each flower is marked with three large blotches. Pkt., 5 cts.; 3 pkts., 10 cts.

\section{BEDDING PANSIES.}

Named sorts. Any 3 Packets for $10 \mathrm{cts}$.

1033. SNOW QUEEN. Pure white, center slightly tinged with yellow. Pkt., 5 cts.

1034 FAUST. King of the Blacks. Pkt. 5c.

1035. GOLDEN GEM. Golden yellow, without black center. Pkt., 5 cts.

1036. SUNSHINE. Striped and Mottled.

One pkt. each, and 1 pkt. Large Flowering Mixed. amounting to 30 cts., for 20 cts.

$10371 / 2$. MASTERPIECE. Page 18. Pkt., 10c. 10381\%. HERCULES GIANT. Page 18. Pkt. 15 cts.

LARKSPUR. Tall Rocket. One of the best known of our garden flowers. H. A

985. Fine Mixed. Best tall varieties. Pkt., 3c. LOBELIA. Cardinal Flower. Fine for edgings. 995. Mixed. Dwarf varieties. Pkt., 5 cts. MARIGOLD. Very effective for beds or borders, free flowering, of easy culture. H. H. A. 1000 . Mixed. Dwarf French varieties. Pkt., 3c. MIGNONETTE. A great farorite on account of its sweet and delicate fragrance. H. A. 1005. Pure Machet. An extra fine strain. Dwarf and compart. Pkt., 5 cts.

MOONFLOWER (Ipomoea Noctiflora). A

beautiful climber, producing large, white flowers. 1010. White Seeded. Pkt.. 5 cts.

OLDS; SELECT MORNING GLORIES. The Finest Annual Climbers in Exist-

ence We take delight in our Morning Glories-large flowers, exquisite colors, magnificent foliage.

1015. Imperial Japanese. Wonders of nature, and of such incomparable beauty that descrip. tions are inadequate. Pkt., 5 cts.; oz., 25 cts.; $1 / 4$ lb. 85 cts.

1016. Dwarf Mixed. Grows 12 inches ligh and blooms later in the day. Pkt., 3c: oz., 5c.

$10291 / 2$. Nicotiana Sandarae. Page 71. Pkt.,10c.

DON'T MISS OUR EARLY BIRD COLLECTION. See Page Seventy.

Ten regetables most suitable for an early garden-all for 50 cents and enclosed in a coupon envelope good for 25 cents on your next order, if it amounts to $\$ 1.00$.

\section{WHITE HOUSE PANSIES.}

Named sorts. Of the largest size. finest form and good substance. Any 2 pkts., 15 cts.

1037 PRESIDENT MCKINLEY. Very effective. Black, bordered with yellow. Pkt., 10 cts. 1038. GIANT PURE WHITE. Large, pure white flowers, without blotches. Pkt., 10 cts.

1039. BLACK PRINCE. Giant jet black flowers. Pkt., 10 cts.

1039 1/2. GOLDEN QUEEN. Large, pure golden rellow, shaded with canary. Pkt., 10 cts.

One pkt. each and 1 pkt. International Mixture, amounting to $55 \mathrm{cts}$., for $40 \mathrm{cts}$.

\section{PETUNIAS.}

Liberal Packets. 1 Pkt. of each, 35 cts. The Petunia is the people's flower. Succeeds well everywhere Very showy in beds and masses; a universal favorite on account of its richness of color, fragrance and continuons blooming. H. H. P.

1040. Fine Mixed. Large flowers and the finest colors mixed. Pkt., $10 \mathrm{c} ; 3$ pkts., $25 \mathrm{c}$.

1041. Hybrids Mixed. Should be in every garden. All colors mixed. Pkt., 5c; 3 pkts., $10 \mathrm{c}$.

1042. Snowball. Pure satiny white flowers, suitable for edgings. Pkt., 5 cts.

1043. Double Mixed. Very handsome, large flowers. Pkt. (30 seeds), 10 cts.

1044. Olds' Finest Mixed. Page 18. Pkt., $15 \mathrm{cts}$.

\section{PHLOX DRUMMONDII.}

Liberal Packets. 1 Pkt. of each, $30 \mathrm{cts}$.

Few flowers more showy or brilliant; no garden complete without Phlox; suitable for beds and borders. H. A

1045. Grandiflora Mixed. The largest flowering mixed varieties. Pkt., 10c; 2 pkts., 15c.

1046. Fine Mixed. Many colors. Plit., 5 ets.

1047. Alba. Large, pure white flowers; fine for borders. Pkt., 5 cts.

1048. Starred and Fringed. A distinct varicty: star-like flowers. Pkt., 5 cts.

1049. New Yellow. Flowers extra large; of a rich straw yellow. Pkt., 5 ets.

10491/2. Snowball. Flowers pure white; reembling snowballs. Pkt., 5 cts.

LLECTION-OUTSIDE BACK COVER. 


\section{OLDS' GILT-EDGED SWEET PEAS.}

Sweet Peas are not only the most popular flowers that grow, but they are also among the most beautiful and fragrant. We have made a very careful selection of the Best and newer sorts, and have arranged them according to colors. Each pkt. contains a full quarter-ounce of seed. Order by number.

Any six 5c pkts. for 25 cts.; any five $10 \mathrm{c}$ ounces for $35 \mathrm{cts}$.; 1/4 lb. of any variety at 3 times cost of $1 \mathrm{oz}$., except where noted; $1 \mathrm{lb}$. of any variety at 3 times cost of $1 / 4 \mathrm{lb}$; $5 \mathrm{lbs}$., 4 times the price of $1 \mathrm{lb}$. Deduct $10 \mathrm{cts}$. per $\mathrm{lb}$. if by express or freight. Special prices on larger quantities.

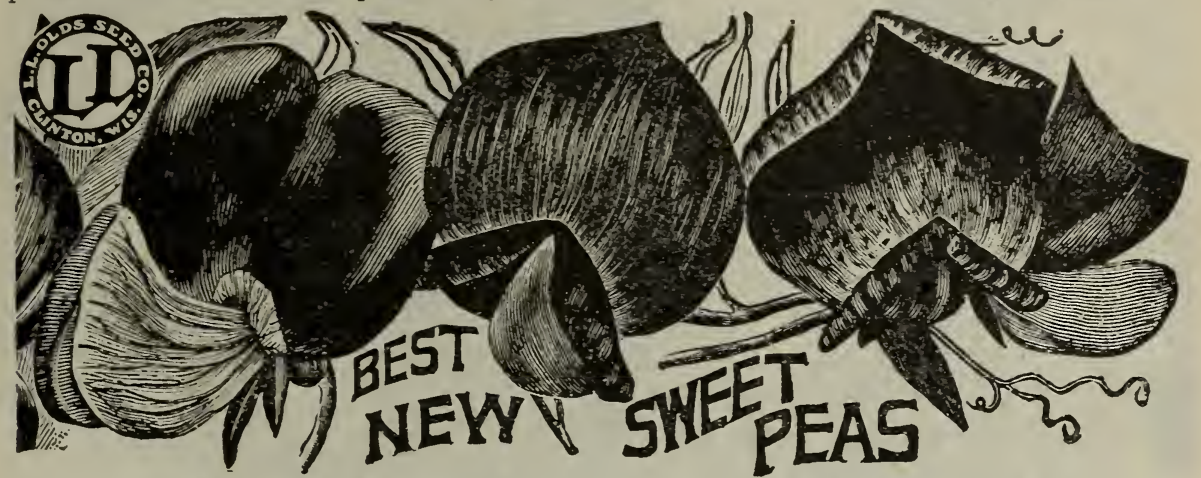

OLDS' PRIZE MIXED.

1100. This mixture is from the Best, newest, larcest flowering sorts, - Giants of California, and is unsurpassed. The seed has been carefully grown from selected stocks. It includes also Eckford's latest introductions. There are no better colors offered in any collection. Pkt., 5 cts.; 0z., 10 cts.; 1/4 lb., 20 cts.; lb., 40 cts.
EARLIEST OF ALL.

1101. This pink and white Sweet Pea blooms 10 days in adrance of any other: highly prized by florists. Pkt., 5 cts.; oz., 10 cts.; $1 / 4$ lb., $15 \mathrm{c}$.

\section{ECKFORD'S MIXED.}

1102. This strain contains a tine assortment of Eckford varieties. Pkt., 3c; 0z., 5c; 1/4 lb., $12 \mathrm{c}$.

\section{LATER INTRODUGTIONS OF EGKFORD AND OTHERS.}

The following list contains the best named varieties, selected from those of most recent introduction and arranged according to color. Except where otherwise noted, Pkt., 5 cts.; oz., 10 cts.

\section{PURE WHITE.}

One Packet each, 15 cts.

1105. Blanche Burpee.

1106. Emily Henderson.

1107 . Sadie Burpee.

1108. Dorothy Eckford. P. 18. LIGHT SHADES

One Packet each, $35 \mathrm{cts}$.

1110. Lottie Eckford.

1111. Modesty.

$1111 \frac{1 / 2}{2}$. Evelyn Byatt. P. 18. 1112. Mrs. Eckford.

$11121 / 2$. Golden Rose. P. 18.

1113. Mrs. Jos. Chamberlain.

1114. Senator.

1115. Stella Morse.
LAVENDER and LIGHT BLUE

1116. Countess of Radnor.

$1116 \frac{1}{2}$. Helen Pierce. P. 18.

1117. Dorothy Tennant.

1118. Lady Grisel Hamilton.

1119. New Countess.

SHADES OF PINK.

1120. Apple Blossom.

$11201 / 2$. Janet Scott. P. 18.

1121. Blanche Ferry.

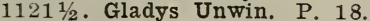

1122. Blushing Beauty.

1123. Katherine Tracy.

1124. Lady Mary Currie.

1125. Lovely.

1126. Prima Donna.

1127. Triumph.

1127. Triumph.

1129. Countess Spencer. P. 18. 1142. Stanley.

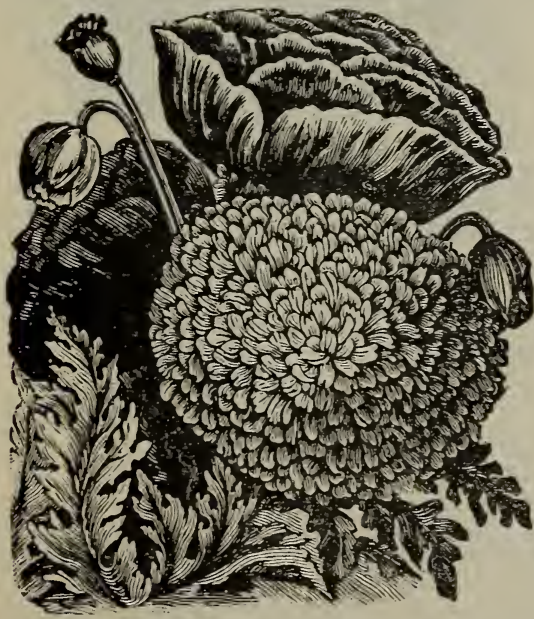

Improved Carnation Poppies.

1151. Lady Blushes. A selection of the best pink shades. Pkt., 5 cts.; oz., 10 cts.; 1/4 lb., 15 cts.

\section{SMART MIXED.}

1152. Red, White and Blue. This mixture is composed of the best red, white and true blue varieties. Pkt., 5 cts.; oz., 10 cts.; 1/4 lb., 15 cts.

\section{DOUBLE MIXED.}

1155. Producing a large per cent of fine double flow. ers. Pkt., 5 cts.; 0z., 10 cts.; 1/4 lb., 15 cts.

DWARF OR CUPIDS.

Pkt., 5 cts.; oz., 10 cts.; 1/4 lb., 20 cts.

1145. White. The first Dwarf Sweet Pea.

1146. Pink. Very dwarf, with large flowers.

1147. Beauty. Delicate rose color.

1148. Primrose. A rich, creamy tint

1149. Alice Eckford. Rich cream, with white wings.

1150. Mixed. Above and other Cupids mixed.

\section{POPPIES.}

Great farorites with everybody-old-fashioned but rery showy. greatly improved varieties.

1050. Improved Carnation. Double mixed. A splendid mixture (see illustration). Pkt., 5 cts.

1051. Single Mixed. A choice selection. Pkt., 3c.

1052. White Swan. Double white; very effectire and desirable. We recommend this variety. Pkt., 5c.

1053. Double Yellow. A new color. Pkt., 5c.
1054. Iceland Mixed. Beautiful and fragrant; excellent for vases. Pkt., 5 cts.

BURBANK'S FAMOUS NEW POPPY, Santa Rosa, No. 10531/2, page 18. Pkt., 10 cts. 


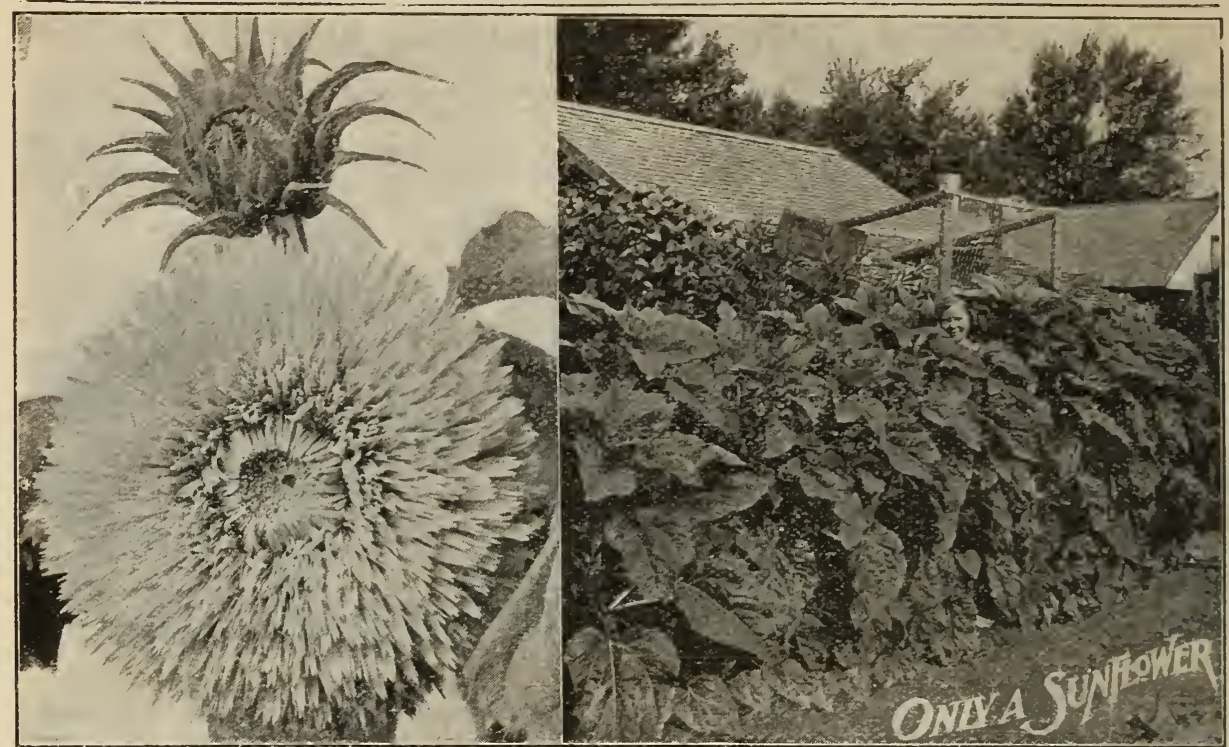

"Only a Sunflower!" and yet where will be found a more perfect or attractive flower? Sec illustration, a photograph of a row when 4 feet high and a flower taken later. These improved Sun. flowers are just right for a background for other flowers, as well as to hide fences, buildings or any unsightly object-a good solution for the back yard problem. They also absorb the impurities of the atmosphere, acting as a preventive of sickness. $H$. A. 1097. Double Globe. Rich-colored flowers. Pkt., 3c. 1098. Miniature. Very bright and showy. Pkt., 5c. 1099. Chigh; flowers perfectly double-see illus 5 to 7 feet high; flowers perfectly double-see illusand perfect in form, resembling double chrysanthemums. Pkt., 5 cts.; 0z., 15 cts.

PORTULAGA. Unrivaled for beauty. H. A. choice double flowers. Pkt., 10 cts.; 2 pkts., 15 cts. 1056. Single Mixed. Large flowers; all colors. Pkt., 5 cts.; 3 pkts., 10 cts.

PRIMULA. Chinese Primrose. Easily grown from seed. Sow very early in spring and transplant.

1060. Large Flowering. Best fringed varieties, mixed. Pkt., 15 cts.; 2 pkts., 25 cts.

1061. Obconica. Grandiflora, mixed. Dwarf and compact. Pkt., 10 ets.; 2 pkts., 15 cts.

RICINUS (Castor Oil Bean). Tall-growing ornamental plants; useful as centers for large beds.

1065. Mixed. 6 to 15 feet high. Pkt., $5 \mathrm{c}$; oz., $10 \mathrm{c}$

SALPIGLOSSIS. Velvet Flower. One of the great

est favorites. A continual bloomer. H. H. A.

1070. Fine Mixed. Very ornamental. Pkt., 5 ets.

SALIVIA SPLENDENS. Flowering Sage. An ex-

cellent bedding plant; very popular. H. H. P.

1075. Scarlet Sage.' See illustration. Pkt., 5 cts.
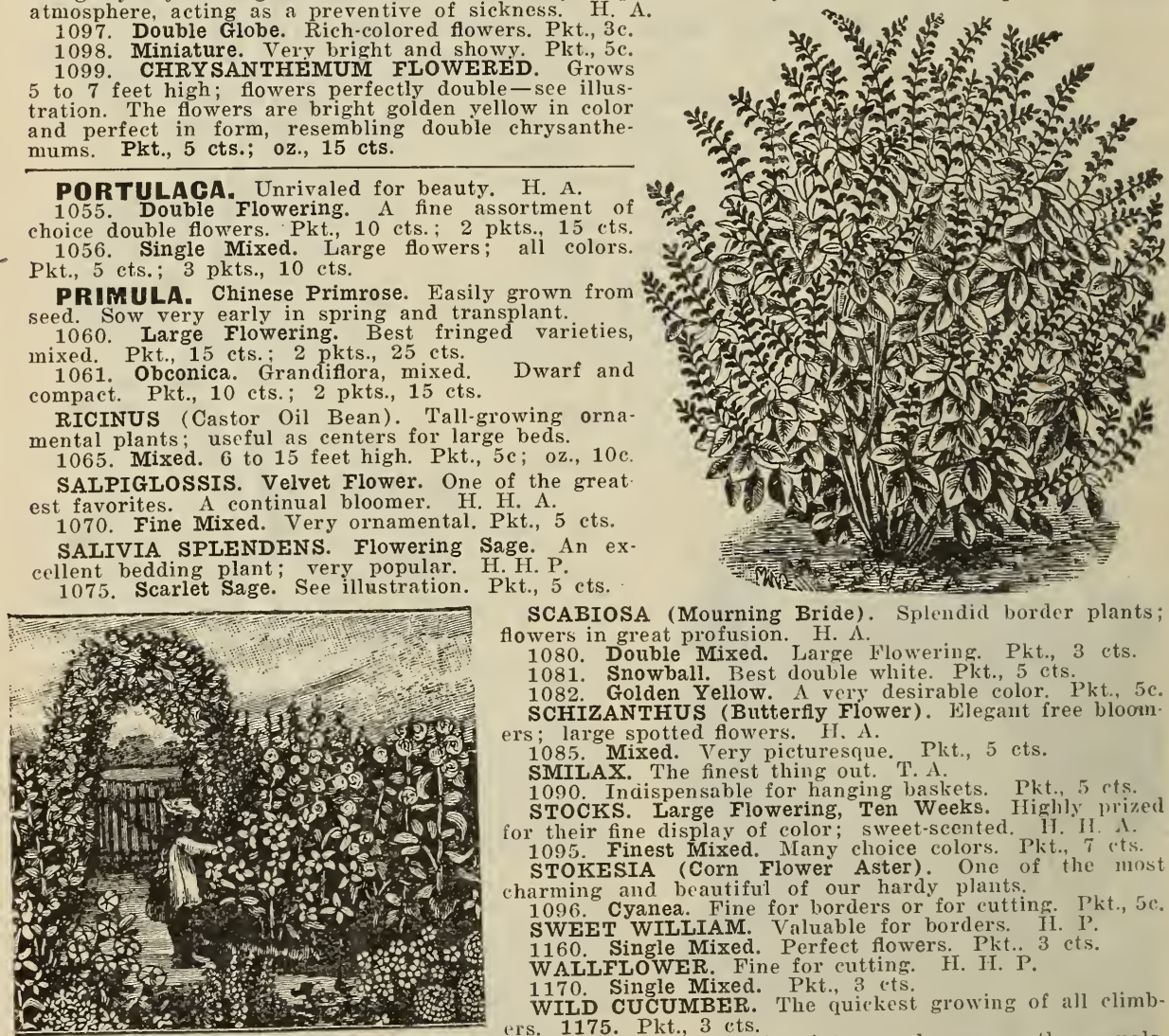

SCABIOSA (Mourning Bride). Splendid border plants; flowers in great profusion. H. $\Lambda$

1080. Double Mixed. Large Flowering. Pkt., 3 cts.

1081. Snowball. Best double white. Pkt., 5 ets.

1082 Golden Yellow A very desirable color Pkt. $5 \mathrm{c}$ SCHIZANTHUS (Butterfly Flower). Elegant free bloom. ers; large spotted flowers. H. A. 1085. Mixed. Very picturesque. Plit., 5 ets. SMILAX. The finest thing out. T. A.

1090 . Indispensable for hanging baskets. Pkt., $5 \mathrm{cts}$. STOCKS, Large Flowering, Ten Weeks. Highly prized for their fine display of color; sweet-scented. 11. II. $\perp$. 1095. Finest Mixed. Many choice colors. Plit., 7 c'ts. STOKESIA (Corn Flower A hardy plants. 1096 cyanea. Fine for borders or for cutting. Pkt., 5c. SWEET WILLIAM. Valuable for borders. IH. P'. 1160. Single Mixed. Perfect flowers. Pkt.. 3 ets. WALIFLOWER. Fine for cutting. H. H. P. 1170 Single Mixed. Pkt., 3 cts.

WILD CUCUMBER. The quickest growing of all climb-

1175. Pkt., 3 ets. 1185. GLORIOUS MIXED. A Whole Garden for 5 cents. This mixture embraces mostly annuals, with a few perennials of easy culture, and will produce a with any order amounting to $25 \mathrm{c}$ or more. tion. Pkt., 5c; 6 pkts., 25 c, or one pkt free, on request, with any orde 


\section{SUMMER FLOWERING BULBS.}

Planted in spring will bloom all summer. For want of space we offer only a small list of the choicest Summer Bubs. Jiany of our customers do not care for a long list, bit there is no reason why every one should not plant a few Gladiolus and Dahlia Bulbs. They are as easily raised as potatoes, and when once given a trial will not be dispensed with. With every dollar's worth of Bulbs ordered, select 15c worth extra.

\section{DAHLIAS.}

Nothing more showy than our large Double Dahlias. Our mixture of Dahlias is made up from a large number of the choicest named sorts. The colors range from deep maroon and crimson through all the shades of pink and yellow to pure white - our white Dahlias have been specially admired. If people only knew what a beautiful show a few dahlia bushes make in a garden, and how easy it is to grow them, everybody would have some.

BEST DOUBLE MIXED. Single tubers by mail, 10 cts, each; 3 for 25 ets.; doz., 8.5 ets., postpaid. Large field roots, in clumps, not prepaid, 15 cts. each; 4 for 50 ets.; $\$ 1.25$ per doz.

NAMED SORTS. The best red, white, rellow and pink-all large Show Varieties; well-formed flowers showing solid colors. Any of the following: Single tubers, each, 15 cts. ; 3 for 35 cts.; doz., $\$ 1.25$, postpaid. Large field roots, in clumps, not prepaid, 30 ets. each; 4 for $\$ 1.00 ; \$ 2.25$ per doz.

STORM KING. Pure white, very large and sliowy. A strong, rigorous grower.

RED HUSSAR. Purest cardinal red; regularly formed flowers, on long, slender stems. A vigorous grower and the best red show variety.

QUEEN VICTORIA. A beautiful deep yellow, finely quilled and perfect in form.

PINK DANDY. The finest clear pink show dahlia to date-see illustration. A strong, rigorous grower, producing large, perfect flowers, on long stems.

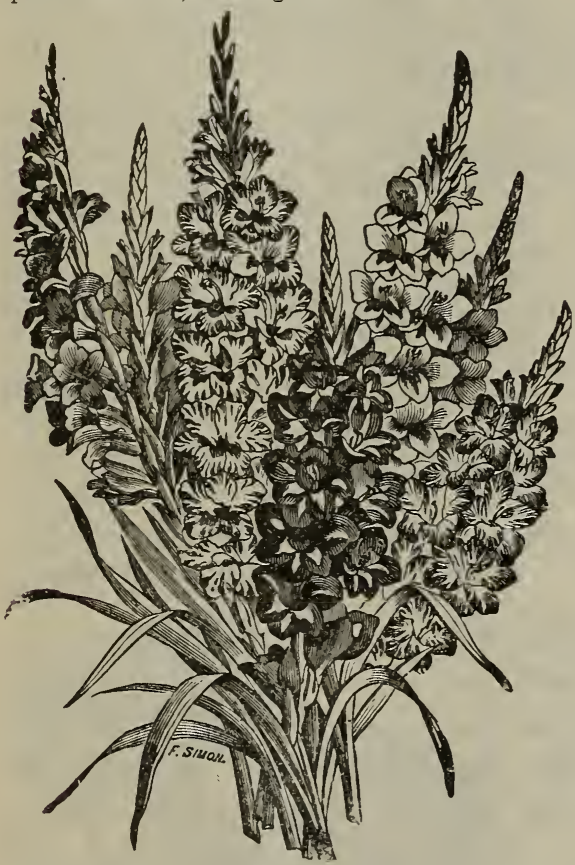

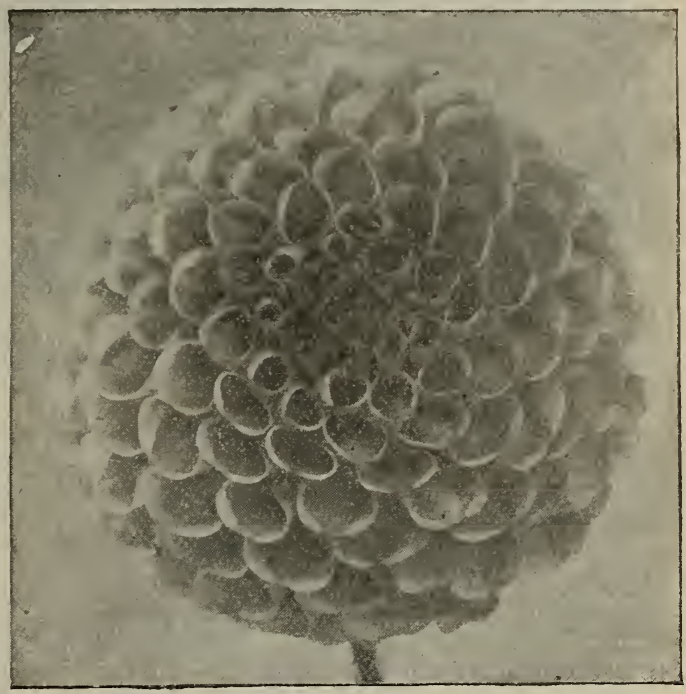

Pink Dandy.

\section{OLDS' GLADIOLUS MIXTURES}

ranks first among all summer flowering bulbs. The tall, stately red, yellow and white flower spikes are very magnificent (see illustration opposite). They are very easily grown and inexpensive. Our mixtures are choice and run to the more desirable light shades.

EXTRA SELECTED MIXTURE. Mostly light and yellow shades. Each, 10 cts.; doz., 50 cts., postpaid. Not prepaid: Doz., 35 cts; $100, \$ 2.25$.

STANDARD MIXTURE. First size, each, 5 cts.; doz., 30 cts., postpaid. Not prepaid: Doz., 20 cts. 100, $\$ 1.25$ Second size, each, 3 cts.; doz, 20 cts., postpaid. Not prepaid: 75 cts. per 100 .

TUBEROSE.

The Sweetest Scented Flower that Grows. The Tuberose is one of the most charming of our summer flowering bulbs; blooming all summer if started in March. Notice our low prices for large bulbs.

EXCELSIOR DWARF PEARL. The largest flowering variety. First size bulbs: 3 for 10 ets.; doz. 30 cts., postpaid. By express, not prepaid: $\$ 1.75$ per 100.

\section{GLOXINIAS.}

Charming flowers, varying from pure white through all shades of rose, crimson and violet. Best Mixed bulbs, each 10 cts.; 3 for 25 cts.; doz., 85 cts., postpaid.

\section{GINNAMON VINE.}

The prettiest thing out. For full description and illustration, see page 87 . Good strong roots, each, 5 cts.; 6 for 25 cts.; doz., 40 ets., postpaid.

\section{BEGONIAS.}

Giant Tuberous-rooted. Tery showy flowers of many brilliant colors.

Sgl. White. . Each, 10c. Dbl. White. . Each, 15c.

“Yellow.. Each, 10c. “4 for 30c. “ Yellow. Each, 15c.

“Scarlet. dozen 80c. “ Scarlet. doz., \$1.35

“ Pink...

\section{VERBENAS.}

Free-flowering, hardy annuals of low, spreading growth; great favorites.

1165. Mammoth Mixed. Largest-flowering. Pkt., 5 ets.

1166. Fine Mixed. All fine shades. Pkt., 3 cts.

1167. Mammoth White. Very choice. Pkt., 5 c.

1168. Defiance. Bright scarlet. Pkt., 5c.

1169. Italian Striped. Very showy. Pkt., 5c.

\section{ZINNIAS.}

Large free-flowering plants; always popular, and fine for borders. There is no flower more easily grown from seed and few bloom so continuously throughout the entire summer. H.H.A.

1180. Superb Double Mixed. Double flowers of good form and large sire. Pkt., 5 cts.

1181. Curled and Crested. A handsome variety; petals curled and twisted. Pkt., 5 cts. 


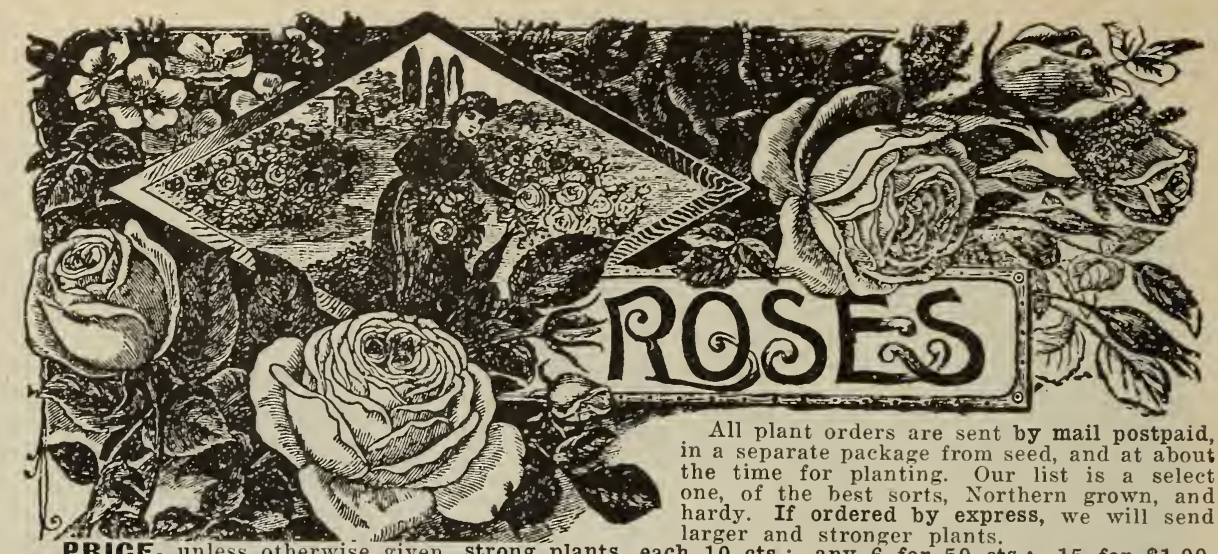

PRICE, unless otherwise given, strong plants, each 10 cts.; any 6 for 50 cts.; 15 for $\$ 1.00$

Three 15-cent plants for 40 cts.; three 20 -cent plants for 50 cts. We can also furnish larger (2 year-old) plants, each $25 \mathrm{cts}$; 6 for $\$ 1.00 ; 15$ for $\$ 2.00$. Three (2-year-old) 15 -cent plants for 75

cts.; three 20-cent (2-year-old) for $\$ 1.00$. For a larger number and for cheaper plants, see Collections, bottom of page.

HARDY LA FRANCE ROSES.

Pink La France. The Old Favorite.

Giant La France. Mad. Caroline. Testout. $15 \mathrm{c}$.

Climbing La France. Peach pink color.

Red La France. Duchess of Albany.

MERMET FAMILY OF ROSES. Catherine Mermet, light pink. The Bride or White Mermet, ivory white. Bridesmaid, deep pink.

FAMOUS SOUPERT ROSES. Best for pots or bedding; ever-blooming. Clotilde Soupert, white, rosy blush in center. Mosella, white with yellow center.

BEST PURE WHITE TEA ROSES. The Queen, pure snow white. Kaiserin Augusta Victoria, best white. 15 cts.

TULIP TEA ROSES. Helen Cambier, coppery yellow, 15 cts. Madame de Watteville, cream yellow.

VELVETY CRIMSON ROSES. Meteor, velvety red, ever-bloomer, 15 cts. Souvenir of Woolton, equal to Jacqueminot. General Jacqueminot, most popular large red.

HARDY EVER-BLOOMING HERMOSAS. Yellow Hermosa, Coquet de Lyon, yellow tea, 15c. White Hermosa, Marie Lambert, no better white. Pink Hermosa, old favorite, hardy as oak.

FOLYANTHA or FAIRY ROSES. Pacquerette, snow white; Mignonette, clear pink, tinged with white.

BEAUTIFUL MOSS ROSES. Glory of Mosses, rich glossy pink, tinged crimson, 20 cts. Comtesse de Murinais, white, tinged flesh color, 20c.

CLIMBING PRAIRIE ROSES. Baltimore Belle, double, blush, carmine, hardy. Greville or Seven Sisters, clusters, white to crimson.

DEEP GOLDEN YELLOW ROSES. Perle des Jardins; you cannot do without this tea. Star of Lyon (Etoile de Lyon), magnificent tea.

MALMAISON ROSES. Souvenir de la Malmai-

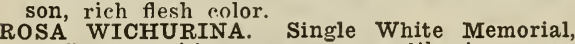
or Japan trailing rose; creeps like ivy.

BABY RAMBLER. The Wonderful New Rose. Full description and illustration, back cover.

BARGAIN GOLLECTIONS OF ROSES. Our selection-all named. Our collections are very fine. Each collection contains some of the $15 \mathrm{c}$ and $20 \mathrm{c}$ novelties. Order by number.

NO 15. Hardy Rose Collection, 25 cts. Four hardy, ever-blooming Roses, no two alike, beautiful colors, will bloom first year

NO. 18. Collection comprises Ten Beautiful Ever-Blooming Roses, all colors, splendid varieties; only 50 cts.

NO. 19. $50 \mathrm{c}$ Collection of Beauties. Comprises four Tea Roses, four hardy Roses, and two Climbing Roses, all for 50 cts.

NO. 21. Collection of your selection, $25 \mathrm{cts}$. Select one each of any three $10 \mathrm{c}$ Roses, or two $10 \mathrm{c}$ and one $15 \mathrm{c}$ Rose. All are $10 \mathrm{cts}$. each unless otherwise quoted.

NEW JAPANESE RAMBLER ROSES, CLIMB ERS. Crimson Rambler, grows 10 to $12 \mathrm{ft}$. in a season; grand climber for buildings. Pink Rambler, hardy, vigorous and fragrant. White Rambler, clusters perfectly double. Yellow Rambler, stands zero weather, immense clusters. HARDY HYBRID PERPETUAL ROSES.

Margaret Dixon. White, awarded gold medal in England, 15 cts.

Mrs. John Laing. Bright shell pink. Gloire de Lyonnaise. The only yellow hybrid perpetual.

Madame Chas. Wood. Flowers extra large, continuous bloomer.

Paul Neyron. Deep slining rose, strong grower. Vick's Caprice. Bright rose, striped rich crim. son, 15 cts.

Dinsmore. Dazzling erimson; stands any winter. Prince Camille de Rohan. The richest crimson. General Jacqueminot. Best rich red.

Madame Plantier. White cemetery rose.

Magna Charta. Bright clear pink, fine.

NEW HARDY ROSES OF SPECIAL MERIT.

Climbing Meteor. Red, brightest perpetual, 15c. Marechal Neil. Deep sulphur yellow.

Mrs. Robert Peary, or Climbing Kaiserin Augusta Victoria. First pure white, hardy, ever blooming, climbing rose, 20 cts.

Champion of the World. Champion bloomer Deep, rosy pink, $15 \mathrm{cts}$.

Golden Gate. Ever-blooming tea, creamy white American Beauty. World-famous. Deep, brilliant red, hardy, fragrant, largest size, everblooming, $15 \mathrm{cts}$

Mary Washington. Pure white, double, vigorous, ever-blooming, raised by George Washington, 15 cts.; 2 for 25 cts

Beauty of Stapleford. Bright pink tea.

Madame Hoste. Lovely, white, tea rose.

Duchess de Brabant. People's rose, pink.

President Carnot. Lovely fawn, shaded pearl, 15 cts.; 2 for 25 cts.

General Robert E. Lee. Nasturtium, yellow.

\section{POPULAR PLANT GOLLEGTIONS.}

Please order by number. These are our selection. All grand named varieties.

NO. 24 50c. -10 choice double and single Geraniums, fine for small garden.

NO. 25. 50c. -12 choice Chrysanthemums, large flowering, all differently labeled.

NO. 26. 50c. -8 choice Carnation Pinks, large, double, sweet scented.

NO. 28. 50c. -12 Coleus. The best and most distinct varieties.

NO 29. 50c.-Window Garden Collection. Comprises 1 scented Geranium, 1 grand double Geranium, 1 splendid Fnchsia, 1 fine ever-blooming Rose, 1 prize Clirysanthemum, 1 double Carnation, 1 choice Coleus, 1 Heliotrope, and 1 Violet. Nine in all. A rare bargain.

PANSY PLANTS. Imperial German. Large flowers throughout the entire summer. Per doz., 35

cts.; $\$ 2.50$ per hundred. HOLT'S MAMMOTH SAGE. The most desirable sage, but never seeds. See page 88. 


\section{THE BEST NEW FUCHSIAS.}

PRICE: $10 \mathrm{cts}$. each. The 7 for 50 cts. Strong plants. New Double White Giant. Largest and best white sort. Black Prince. Finest Fuchsia, free win te r blonmer.

$\mathrm{J}$ u p it e r

Wo on d e rf u $\mathrm{l}$

large flowers

Storm King.

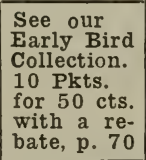

Double flowering, weeping, crimson.

Mrs. E. G. Hill. White and red, graceful and beautiful.

Champion of the World. Coral red, dark purple. large.

Spiceosa. Coral red, very

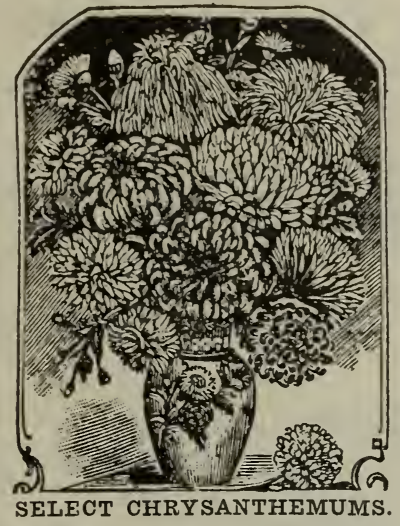

\section{SELEGT}

CHRYSANTHEMUMS.

A list of the 12 choicest and most PRICE: 7 cts. each; any 4 for 25 cts.; 10 for 50 cts.

Helen Bloodgood. Very bright pink. Frank Thompson: White, fluslied with pink

Golden Wedding. Finest of all ellows.

Maud Dean. Almost pure self-pink. Wm. H. Chadwick. A grand double white. Best of its style.

Black Hawk. A fine deep crimson. Ivory. White flowers. Perfectly Ivory and a general favorite.

Major Bonaffon. Deep golden yellow. Periect in form and color. Mrs. W. B. Chamberlain. Delicate lavender pink; curved petals.

Mrs. Perrin. Brightest of pinks.

Miss Minnie Bailey. Very fine pink.

Invincible. The best late white.

SWEET VIOLETS.

DOUBLE GERANIUMS.

Price $10 \mathrm{cts}$. each. Any 6 for $40 \mathrm{cts}$.

Gen. Grant. Orange scarlet, fine bedder.

Firebrand. Large, dazzling scarlet.

La Favorite. Double, white, magnificent.

S. A. Nutt. Double crimson, grandest of all.

Queen of the Fairies. Most beautiful.

Jean Viand. Large, double pink.

Emerson. Distinct rosy salmon.

John Doyle. Tery bright red.

Hoff Beach. Deep magenta. Very fine.

BEST SINGLE GERANIUMS.

Wonder. Dazzling scarlet, very large.

Mrs. E. G. Hill. Salmon pink.

Snowdrop. Pure white, very fine.

Clyde. Rich red, a grand bedder.

Granville. Clear, rosy pink.

IVY GERANIUMS.

Price $10 \mathrm{cts}$. each. Set of 3 for $25 \mathrm{cts}$.

Joan of Arc. Double, white as snow.

Comtesse Horace de Choiseul. Brightest golden salmon.

Souv. Chas. Turner. Bright pink.

\section{BEAUTIFUL COLEUS.}

Price 5 cts.

Fire Brand. Dark crimson, shaded.

Fire Crest. Crimson, marked yellow.

Golden Bedder. Deep golden yellow.

Golden Verschafeltic. Best yellow.

Yeddo. Yellow, splotched bright green.

Spotted Gem. Crimson, gold and bronze.

Beckwith Gem. Color gorgeous.

\section{SUPERB CANNAS.}

Choicest Novelties. The set of 6 for $60 \mathrm{cts}$ Madame Crozy. Vermillion, gold border. $10 \mathrm{cts}$.

Queen Charlotte. Glowing scarlet. $10 \mathrm{cts}$.

Florence Vaughan. Yellow spotted. $10 \mathrm{cts}$.

Italia. Gigantic, scarlet, yellow border. 15 cts.

Austria. Orchid, yellow with crimson. 15 cts.

Alphonzo Borevier. Dark crimson. 20 cts.

\section{HELIOTROPES.}

Price $6 \mathrm{cts}$. each. The 4 for $20 \mathrm{cts}$. Albert Delaux. Golden foliage, lavender flower. Snow Wreath. Flowers of snowy whiteness.

The Queen. Purple with white center.

Florence Nightingale. Light lavender.

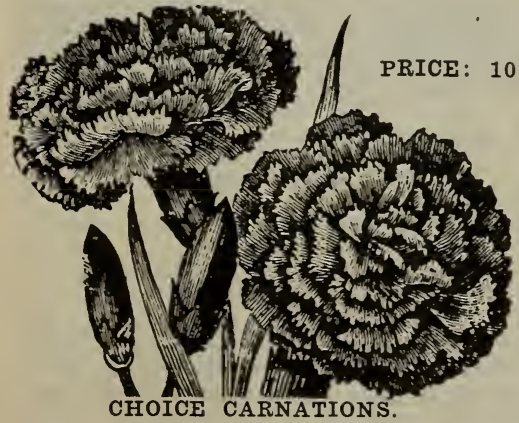

CHOICE CARNATIONS.
Price 10 cts. each. 3 for 2

Swanley White. Best white, fragrant.

Hardy Russian. Deep purple.

SNOWBALL (Viburnum Sterilis). Height 8 to 10 feet, snow white, flowers in June, $10 \mathrm{cts}$. CHINESE HHBISCUS. We have a very fine variety of these beautiful plants, double and single. Price $10 \mathrm{cts}$; 3 for $25 \mathrm{cts}$.

PEACHBLOW. The new pink Hibiscus. 15 cts.

OTAHEITE ORANGE. A dwarf Orange, bearing beautifully colored fruits. Price $15 \mathrm{cts}$. each; 2 for $25 \mathrm{cts}$. SWEET SCENTED JASMINES. Confederate Jasmine. A grand climber.

Poetica. Double, cream white flowers.

HARDY LILIES.

Lillium Auratum. Grandest of all. $25 \mathrm{cts}$ PLUMBAGOS.

Capensis. Blue, always in bloom. 15 cts.

\section{GHINESE MATRIMONY VINE.}

Hardy everywhere, covers a veranda, purple flowers and scarlet berries from spring until late fall. $10 \mathrm{cts}$; 3 for $25 \mathrm{cts}$.

\section{ABUTILON.}

Flowering Maple. $10 \mathrm{cts}$.; any 4 for $35 \mathrm{cts}$. Rosaflora. Shell pink. Beautiful.

Golden Fleece. Enormous yellow flowers.

Eclipse. Flowers deep scarlet, trailing habit.

Robt. George. Flower's orange, veined maroon.

Snowdrift. Flowers pure white.

ACALYPHA SANDERII. Comet plant. Introduced from the Philippine Islands by Admiral Dewey. Scarlet flowers 12 inches long. 10 cts.

\section{AGERATUM.}

Great bedding plants. $5 \mathrm{cts}$; 3 for $10 \mathrm{cts}$

Stella Gurney. Silky blue. Princess Pauline.
Maid of Orleans. Elegant bloomer, white.

Harrișii. The Bermuda or Easter Lily. 20 cts.

Capensis Flora Alba. Clear white. $10 \mathrm{cts}$.

Mrs. Thos. sort in Boston; of a true pink color and very large in size. Della Fox. Rosy, orange shade, striped with carmine. Jubilee. Very dwarf, rich, dazzling bright scarlet. Abundance. Flowers large and perfect, bright rosy pink. Gold Nugget. A pure yellow, of strong. growth.

Gaiety. Body of the flower pure white; large and full. Her Majesty. The standard white, long, strong stem. Morning Glory. A beautiful light pink satin color. Prosperity. The largest carnation ever offered.

White Cloud. Large, white, one of the best.

Whitcomb Riley. A faint blush, fluffy in appearance, ne of the finest in form.

Enchantress. The $\$ 10,000$ beanty. The greatest forward stride in carnations since the advent of Mrs. Thos. Law. son; large flowers of a rosy blush-pink, on a strong stem. (Larger plants furnished, at double the above prices. CINNAMON VINE and CLEMATIS-page 87.) 


\section{GARDEN AND FARM TOOLS.}

\section{PLANET JR. FARM AND GARDEN TOOLS.}

Space will not permit our showing and describing all of the Planet Jr. tools, but we will send a fully illustrated catalogue free for the asking. Planet Jr. goods are standard machines, the best on the market. Note our Reduced Prices. Fifty Cents Saved on every Planet Jr. purchased of us.

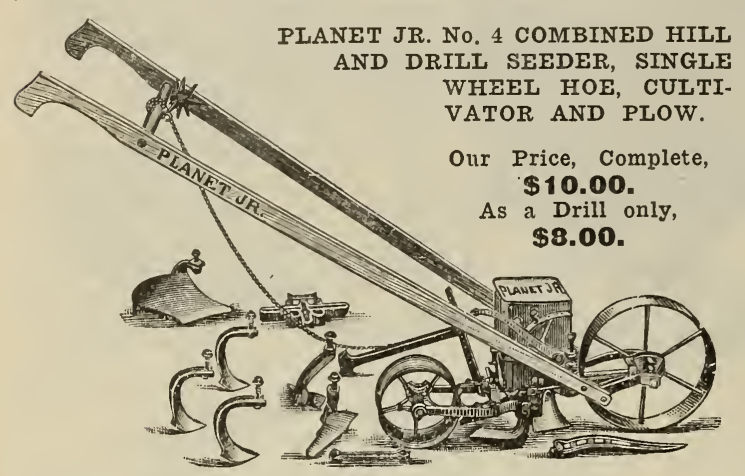

This most perfect development of the hand seed drill sows evenly in drills, and also drops in single hills, at $4,6,8,12$ or 24 inches apart. No time is lost; no seed is wasted. It covers and rolls down and marks the next row; hopper holds 2 quarts. The drill is detached and the tool frame substituted by removing but one bolt. It then becomes a single wheel hoe. It is useful almost every day of the season. The accurate lill-dropping drill, which gives a regular stand of plants with the least seed, saves its cost over and over in seed alnne. We guarantee this drill to be more accurate than any other made and to give satisfaction.

No. 25 Combined Machine. A com bination of the No. 4 Drill and No. 12 Double Wheel Hoe.

Our Price, Complete, $\$ 13.00$

\section{PLANet JR. NO. 12 dOUble WheEL hOE.}

For easy, clean and perfect gardening, the kind which will make your garden the talk of the neighborhood, nothing is quite equal to this Planet Jr. No. 12 Double Wheel Hoe. It is suited to all garden crops. You can do more and better hoeing with it in one day than you can do in three with a hand hoe.

Our price, with attachments, $\$ 6.50$.
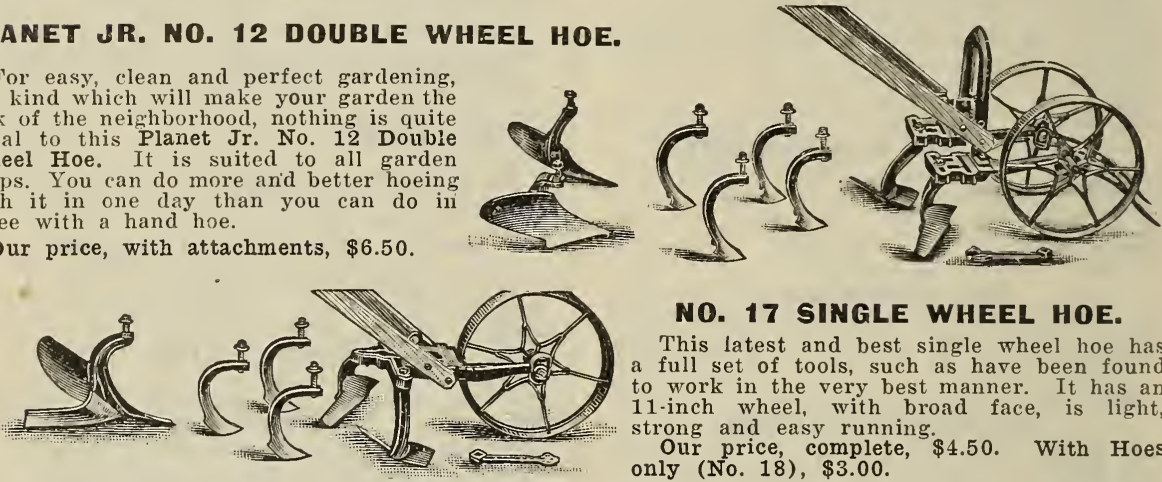

NO. 17 SINGLE WHEEL HOE.

This latest and best single wheel hoe has a full set of tools, such as have been found to work in the very best manner. It has an 11-inch wheel, with broad face, is light, strong and easy running.

Our price, complete, $\$ 4.50$. With Hoes only (No. 18), $\$ 3.00$

NO. 5 HORSE HOE. Only $\$ 6.85$.
NO. 8

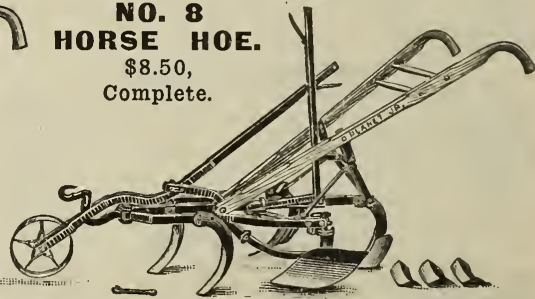

PLANET JR. HORSE TOOLS.

The No. 8 Combined Horse Hoe and Cultivator is probably the most perfect, up-to-date cultivator in the world. It has both depth and width levers, deptl regulator and all the latest improveregulator and all the latest improve-
ments. Light and easily handled, but strongly built, it is the tool that pleases.

Our price, complete, $\$ 8.50$

Without Depth Regulator (No. 7) $\$ 8.00$.

No. 5 Horse Hoe. One lever only. A special style. Only $\$ 6.85$.

No. 4. No levers. Only $\$ 6.10$.

No, 4, Plain Cultivator, $\$ 4.75$.

12-Tooth Harrow. This is the popular tool among sugar beet, strawberry and tobacco growers. The small, chisel-shaped teeth do thorough
work, yet without throwing earth on the young plants. Price, only $\$ 6.90$; with Pulverizer, $\$ 8.50$. Remember, 50 cents saved on every Planet Jr. Tool bought of us. Ask for complete catalogue. 


\section{THE BARKER WEEDER AND MULCHER.}

It operates on the plan of a lawn mower. It is better than a hoe. It is ten times as fast. It is easy to operate. It forms a dust mulch. Bny a Barker Weeder and Mulcher and cut your garden the same as rou buy a lawn mower to cut your lawn. It cuts the weeds under the ground as well as the weeds out of the ground. It pulverizes the ground fine, which holds the moisture to feed the plant.

\section{IT HAS NO RIVALS.}

It is so different from all others that it is in a class by itself.

You will be interested in it as soon as rou see it. When you have seen the kind of work it does you will want it.

It makes no difference how many other hand cultivators you liave or have used you will be couvinced after trying it that this one does different work from any of them and that it will pay you to have it.

The lower knife in connection with the revolving blades kills every weed.

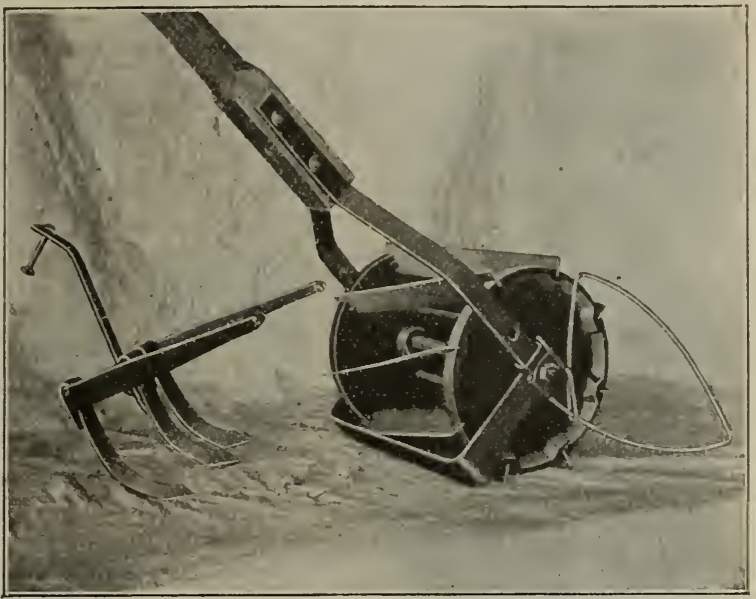

To appreciate the value of this tool you must take it to the field; you cannot judge it properly by looking at it. Take it out into the patch, pick out a piece of regetation that needs weeding. Notice the work it does. Let your man work it. If you are not satisfied with it after giving it a fair trial, you can return it. Hundreds of the best market gardeners and onion growers have taken this tool to try and have kept it and bought more. It is a money saver.

Made in three sizes: 6-inch cut for lettuce and crops planted in close rows; $81 / 2$-inch cut, the standard size, for onions and ordinary market garden crops; 11 -inch cut for rows 14 to 18 inches apart.

Price, any of the three sizes, complete, with all attachments, only $\$ 5.00$.

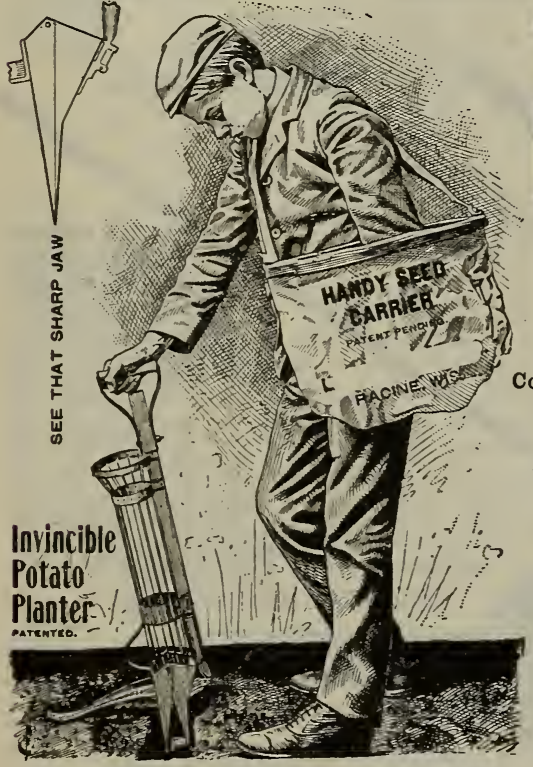

INVINGIBLE POTATO PLANTER.

A great labor saver. Two acres a day can be planted with one of these tools. The open wire sleere reduces the wind resistance to a minimum. The sharp jaw enters the ground as easily as a spade. The handle is adjustable. It has a double leaf spring, and is strong and durable.

Price, $\$ 1.25 ; 3$ for $\$ 3.25$.

\section{HARDY SEED CARRIER.}

Made especially for the purpose, with iron loop to keep the moutl open: strons and convenient. Price, $45 \mathrm{c} ; 3$ for $\$ 1.15$.

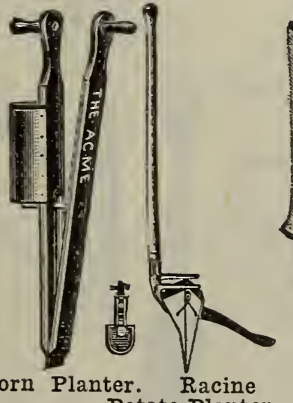

Potato Planter.

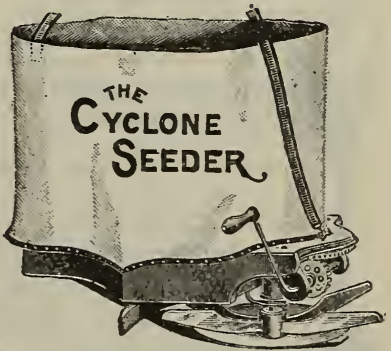

GYGLONE SEEDER.

Warranted to Give Satisfaction. The Cyclone has a national reputation as a High-Grade

Seed Sower. It is built, not for cheapness, but for durability and accurate work. It weighs less than 4 lbs., yet is strong and durable, and so simple that a boy can operate it. Just the thing for sowing all kinds of clover and grass seed, millet, rape, and even larger grains. Price, reduced, $\$ 1.25$.

\section{RAGINe POtato Planter.}

A popular, straight handle, stick planter, at a low price. Price, only $60 \mathrm{c}$; 3 for $\$ 1.75$.

ACME CORN PLANTER.

Simple, durable and accurate. With the Pumpkin Seed attachment pumpkins can be planted at the same time. Price, plain, 65c; with Pumpkin Seed Attaclment, 80c.

\section{TRIUMPH POTATO EYE PLANTER.}

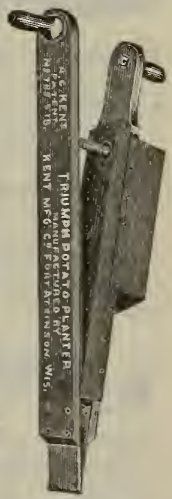

A new tool. Just what many hare been looking for. Drops two eyes in a place and does the work accurately and well. Sares half the seed, as five bushels of potatoes will plant an acre this way and make a good stand. Two potato eye cutters, as illustrated on page 29 included with each planter. Price, \$2.25.

Eye Cutter alone, 15c.
Potato Eye Planter. 


\section{"AUTO-SPRAY" NO. 1.}

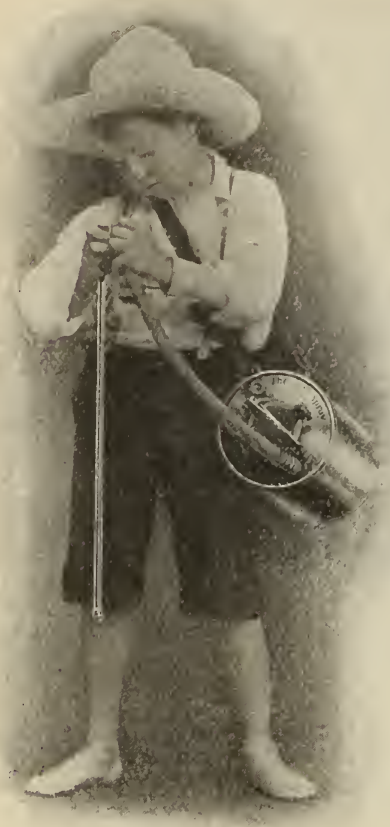

The "Auto-Spray"' Boy.

The "Auto-Spray" is a standard machine, probably more largely used now than any other. It is the favorite with nurs erymen, potato growers and market gardeners everywhere, is used by nearly all the State Experiment Stations and by the U. S. Gorernment, as well as by thousands of representative agriculturists and horticulturists throughout the world.

The "Auto-Spray" works automatically for six to fifteen minutes; according to the nozzle opening. It may be charged in fifteen seconds by a few strokes of the plunger. It has a capacity of four gallons, and when properly charged contains three gallons of solution and one gallon of compressed air. Three gallons of solution, or one charge, will easily cover one half acre of potatoes or other similar crops. One boy with an "Auto-Spray" will do as much as three men with the ordinary hand atomizer.

Our Price: Galvanized, with Stop Cock.......\$4.50

“، “ Galvanized, with Auto-Pop .......

Brass, with Stop Cock ........6.6.

(Descriptive Auto-Spray circular free.)

"AUTO-SPRAY" NO. 2.

A bucket sprayer, specially fine for whitewashing hen houses as well as for throwing a stream of water. May be fastened rigidly to any pail or bucket. Convenient for all spray purposes.

Price, with 3-foot hose and special "Auto-Spray" nozzle, only $\$ 3.50$.

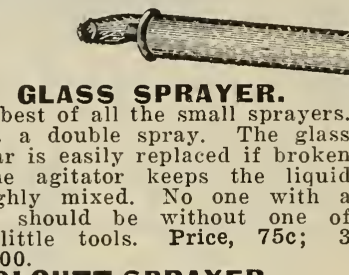

OLGUTT SPRAYER.

A tin sprayer with double tube,

Throws a dhe glas fruit jar is easily replaced if broken and the agitator keeps the liquid garden should be without one of these little tools. Price, 75c; 3
for $\$ 2.00$. throwing a double spray. Price, only 60 cents.
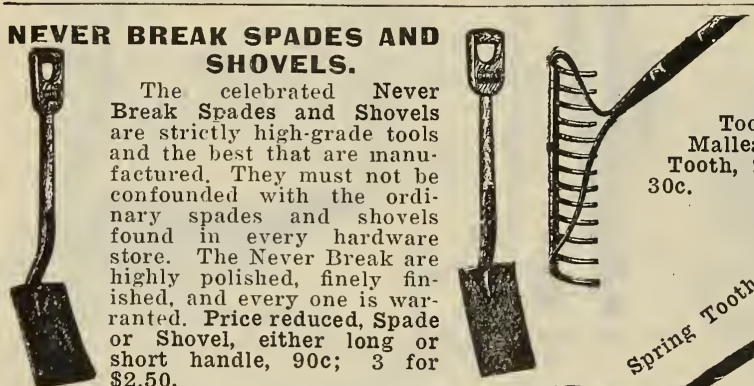

GARDEN RAKES SHOVELS.

The celebrated Never Break Spades and Shovels are strictly high-grade tools and the best that are manufactured. They must not be confounded with the ordinary spades and shovels found in every hardware store. The Never Break are highly polisled, finely finished, and every one is warranted. Price reduced, Spade or Shovel, either long or short handle, 90c; 3 for $\$ 2.50$.
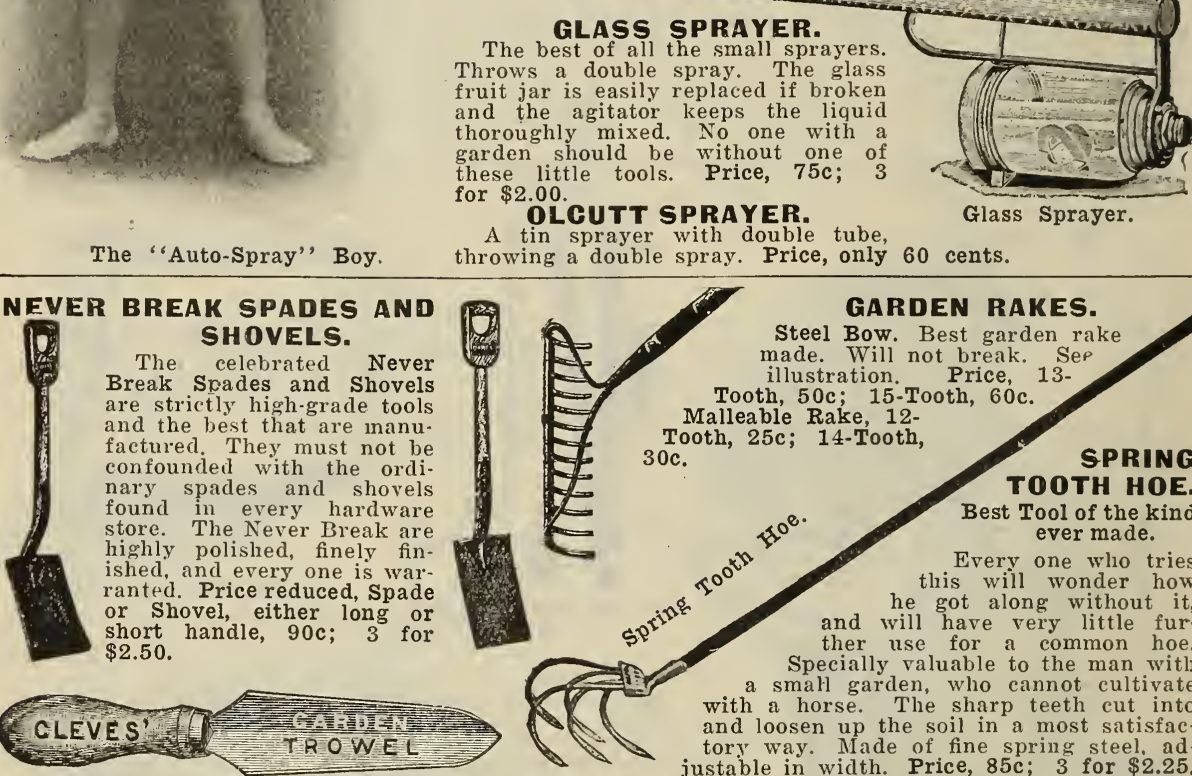

Best garden rake

illustration not break. Se

Tooth, 50c; 15-Tooth, 60c.

Malleable Rake, 12Tooth, 25c; 14-Tooth $30 \mathrm{c}$.

SPRING TOOTH HOE.

Best Tool of the kind ever made.

Every one who tries this will wonder how he got along without it, and will have very little further use for a common hoe.
Specially valuable to the man witl
with a harse. The sho cannot cultivate ther use for a common hoe.
Specially valuable to the man witl
with a horse. The sho cannot cultivate ther use for a common hoe.
Specially valuable to the man witl
with a horse. The sho cannot cultivate and loosen up the soil in a most satisfac tory way. Made of fine spring steel, ad justable in width. Price, $85 \mathrm{c}$; 3 for $\$ 2.25$.

\section{CLEVES' ANGULAR TROWEL.}

A high-grade, handsomely finished and polished trowel, with sharp point. Price, small size, $20 \mathrm{c}$; by mail, $23 \mathrm{c}$ Large size, $30 \mathrm{c}$; by mail, $37 \mathrm{c}$.

NEVER-BREAK TROWEL.

A cheap trowel, but made very strong. Will not break.

Price, 10c; by mail, 18c.

POTATO EYE CUTTERS. See pages 81 and 29.

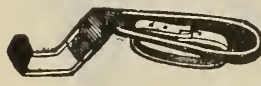

IANG'S WEEDER.

Finest thing- out for hand-work in onions and other similar crops. $25 \mathrm{c}$.

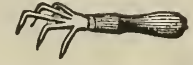

Excelsior Weeder. A popular Hand Weeder for use among sinall and tender plants, $10 \mathrm{c}$; by mail, Price.

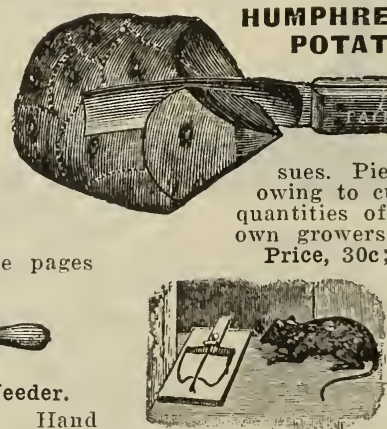

Out $0^{\prime}$ Sight Mouse Trap. No bait required. Simply set them along rumways. Price. $10 \mathrm{c}$ : 3 for 25 c, postpaid.
CONGAVE

IAargely used b y practical pritato growers. Cuts to one eye without injuring the vital tis an stick together, We sell large Many of our ed surface. .

\begin{abstract}
3 for $75 c$, postpaid.
\end{abstract}

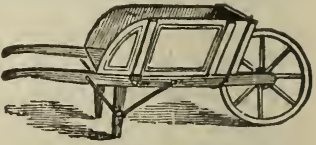

Garden Wheelbarrow.

No farmer or gardener should be without one of our garden wheelbarrows. Shipped knockdown.

Price reduced, only $\$ 3.00$. 


\section{HAMMOND'S SLUG SHOT.}

5.
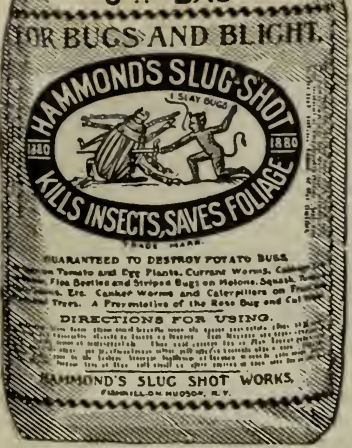

Used from Ocean to Ocean. Annual output, orer 300,000 lbs. every year for 20 years. A light, composite, fine powder, easily distributed by duster, bellows, or in water by spraying. Thoroughly reliable for killing currant worms, potato bugs, cabbage worms, lice, slugs, etc.,

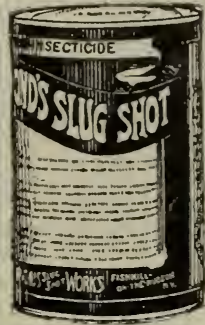

Pound Carton, 100 By mail, 26c.

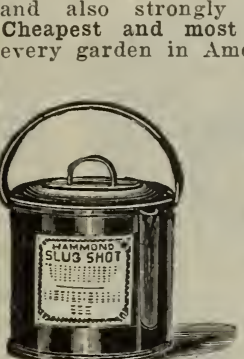

DUSTER. impregnated with erica, during the growing time, to kill bugs and save foliage. We sell large quantities of Slug Shot every year, and know it gives satisfaction to our customers.

Price, 1 lb. Cartons with perforated top, only $10 \mathrm{c}$ each; 5 and $10 \mathrm{lb}$. bags, $6 \mathrm{c}$ per lb.; 25 to $50 \mathrm{lbs}$, at $5 \mathrm{c}$. Postage extra at $16 \mathrm{c}$ per $1 \mathrm{~b}$.

\section{SLUG SHOT DUSTER.}

Made of tin, with finely perforated bottom. Most economical and effective way of applying the powder. Price, 2 qt. size, $30 \mathrm{c} ; 4$ qt. size, $45 \mathrm{c}$.

\section{BUG DEATH.}

THE UP-TO-DATE SUBSTITUTE FOR PARIS GREEN.

Does not burn the leaves, however freely applied. Is a fine powder and adheres readily to the rines, so that it is not necessary to apply it after every shower. May be applied wet or dry. It is non-poisonous, as far as human beings are concerned.

Kills currant and cabbage worms and striped bugs on vine crops, but its great value is for the potato crop. It not only kills the bugs, but prevents blight and keeps vines green and healthy. More expensire than Paris Green, because a larger amount is required, but careful experiments prove that it more than pays for its cost in the increased vigor and growth of the potatoes.

Price: 1 lb., 15c; 3 lbs., 35c; 5 lbs., 50c; 121/2 lbs., $\$ 1.00$; $100 \mathrm{lbs}, \$ 7.50$. Postage extra at $16 \mathrm{c}$ per lb.
Bug Death booklet free on application.
BUG DEATH

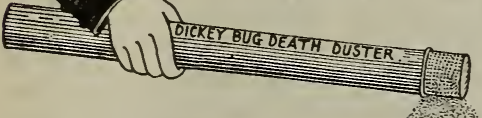

\section{DUSTER.}

A cheap and effective little instrument for applỳing Bug Death dry.

Price, 25 cts.
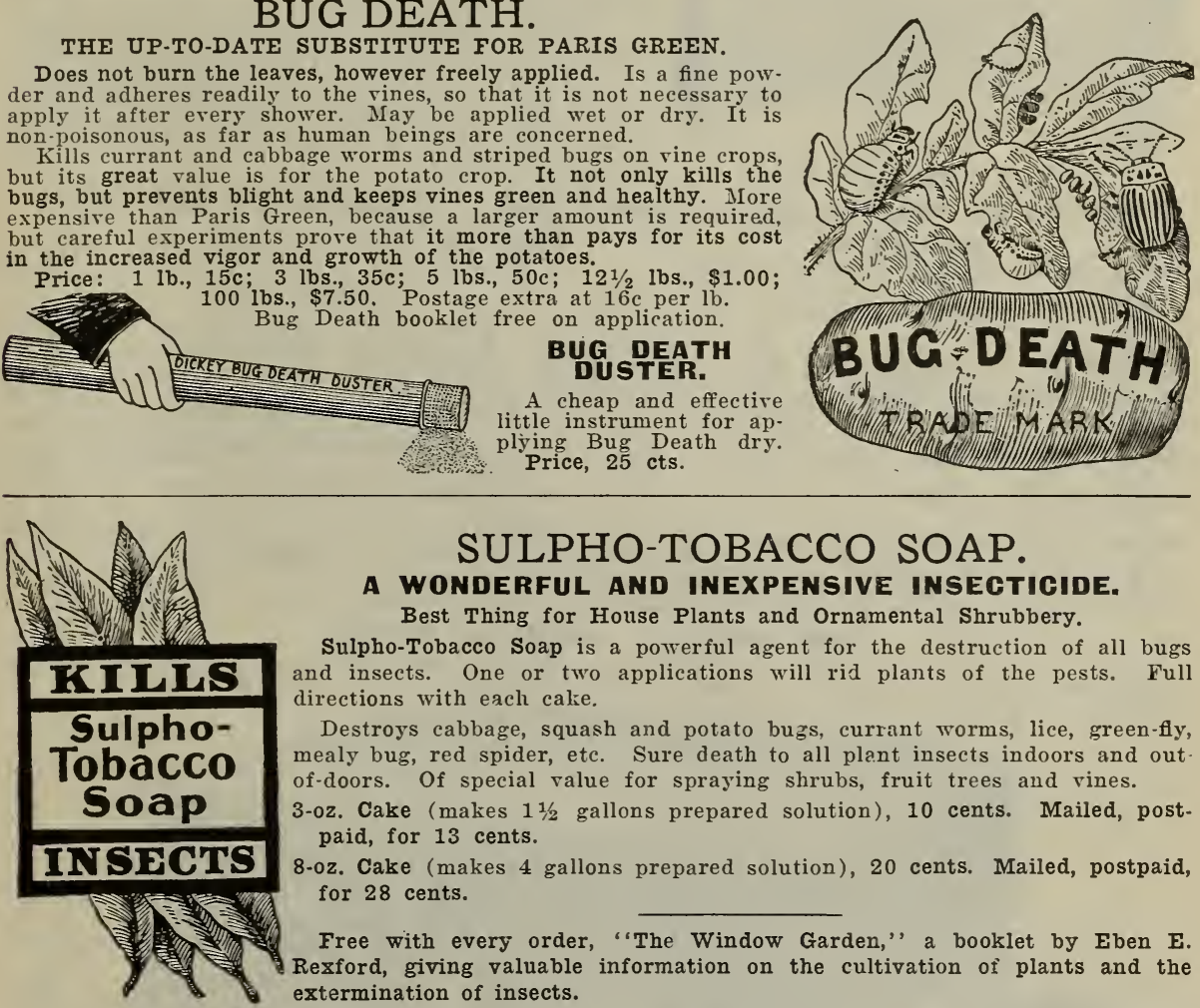

\section{SULPHO-TOBACCO SOAP.}

\section{A WONDERFUL AND INEXPENSIVE INSECTICIDE.}

Best Thing for House Plants and Ornamental Shrubbery.

Sulpho-Tobacco Soap is a powerful agent for the destruction of all bugs and insects. One or two applications will rid plants of the pests. Full directions with each cake.

Destroys cabbage, squash and potato bugs, currant worms, lice, green-fly, mealy bug, red spider, etc. Sure death to all plant insects indoors and out. of-doors. Of special value for spraying shrubs, fruit trees and vines.

3-oz. Cake (makes $1 \frac{1 / 2}{2}$ gallons prepared solution), 10 cents. Mailed, postpaid, for 13 cents.

8-oz. Cake (makes 4 gallons prepared solution), 20 cents. Mailed, postpaid, for 28 cents.

Free with every order, "The Window Garden," a booklet by Eben E. Rexford, giving valuable information on the cultivation of plants and the extermination of insects.

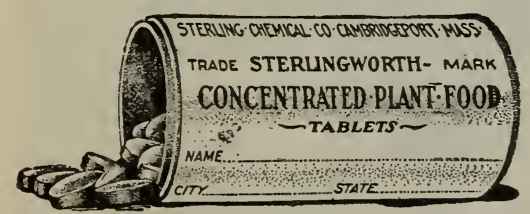

\section{STERLINGWORTH}

\section{PLANT FOOD TABLETS}

Contain Nitrogen, Ammonia, Phosphoric Acid and Potash. A New Scientific, Odorless, Concentrated Fertilizer for Potted Plants and Vegetables.

Takes the place of liquid manure. Used by dis. solving in water. By being wholly soluble they start the plants at once into healthy and vigorous growth and make them grow and bloom luxuriantly. These Tablets drive troublesome insects and worms from the soil.

They are odorless, non-poisonous, uninjurious and are clean and easy to handle, and owing to their concentrated form are far superior to other plant fertilizers which are coniposed largely of waste material and useless filler. If your plants are not doing well, try Sterlingworth Plant Food Tablets, and see how quickly they are benefited.

Trial size box, sufficient for 10 house plants for 3 months, 10 cents, postpaid. Regular size box, sufficient for 35 plants for 3 months, 25 cents, postpaid. 


\section{POULTRY SUPPLIES.}

\section{PRAIRIE STATE HIGH-GRADE INCUBATORS AND BROODERS.}

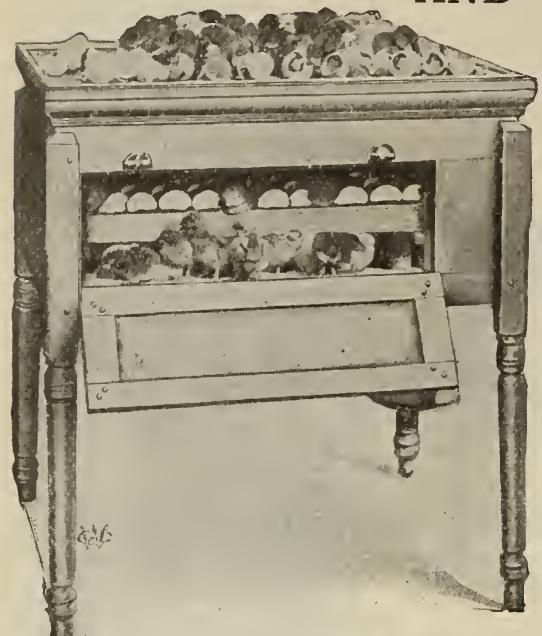

A Lot of Fluffy Little Fellows.

The demand for Incubators and Brooders constantly increases. No farm is really up-to-date now without one. There are a great many different makes. Some are all right, but most of them are made to sell, and sell cheap. A cheap incubator is of all things the poorest investment a person can make. We handle the Prairie State exclusively, because we know it is thoro'ighly reliable and gives satisfaction. y oreover, the manufacturers of the Prairie State are progressive people and are all the time making valuable improvements. Their new 1907 Diffusion Incubators are with. out doubt the most perfect incubators on the market.

The Prairie State has been 21 years in practical use, 1886 to 1907 , longer than any other machine.

More Prairie States are in use today than any three other makes combined.

It is a high per cent hatcher, turning out 85,90 and 95 chicks to every 100 fertile eggs.

The Prairie State is a wonderfully durable incubator. Both the workmanship and quality of material are guaranteed for 20 years.

It is the incubator for the amateur as well as the experienced, as it requires very little care and watching.

We carry a large supply of Prairie State goods in stock, and are prepared to fill orders direct from our warehouse here at Clinton, or, if nearer, from the factory in Pennsylvania. Customers pay freight or express in all cases.

\section{PRICES OF PRAIRIE STATE INCUBATORS AND BROODERS FOR 1907.}

\section{INCUBATORS}

Junior No. 1, 60 Eggs (Improved 1907

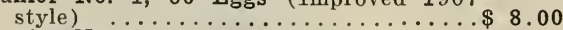

Junior No. 2, 110 Eggs (Improved 1907 style)

iffusion No. 150 . 12.00

Diffusion No. 2, 240 Eggs (New 1907) . 29.00

Diffusion No. 3, 390 Eggs (New 1907).. 35.00

Baby No. 1, 50 Eggs (1905 style, reduced price

Baby No. 2, 100 Eggs (1905 style, reduced price) Special No. 0, 50 Eggs (1905 style, reduced price)

Special No. 2, 200 Eggs (1905 style, re-

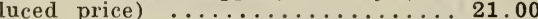

LARGE ILLUSTRATED CATALOGUE, fully describing all the different styles and sizes of Prairie State Incubators and Brooders, Drinking Fountains, Feeding Troughs, etc., free.

\section{OUR SPEGIAL PREMiUm OfFER.}

With every Incubator or Brooder ordered, we will send free a dollar package of International Poultry or Stock Food. (See next page.) Tell us, when you order, which you want.

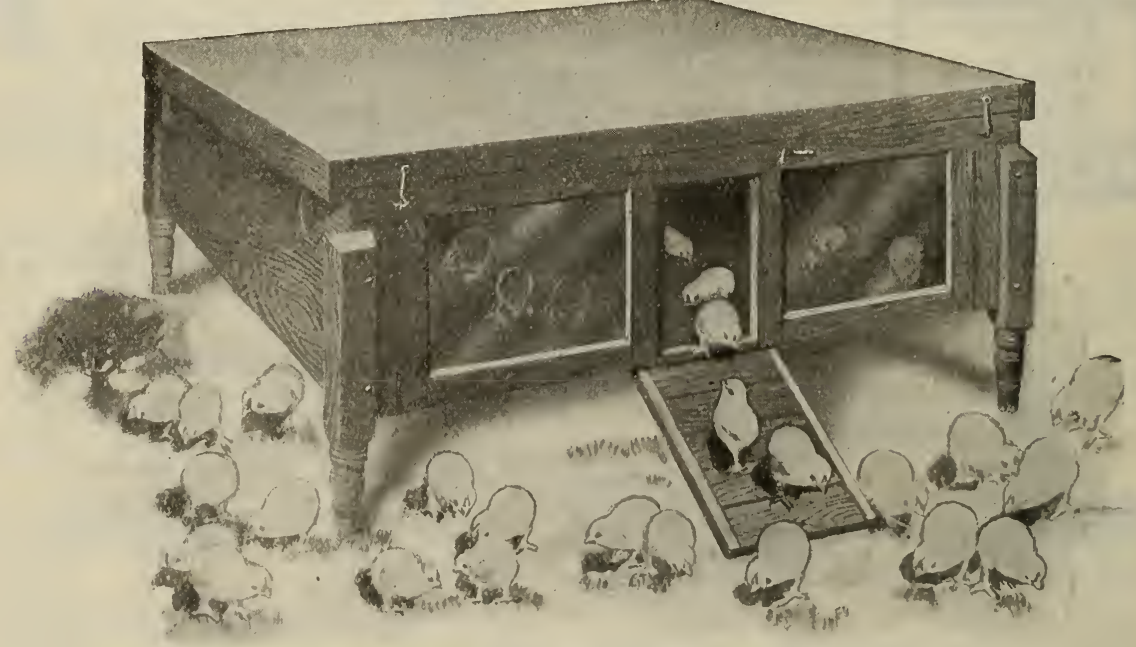

Style O, Outdoor Hot-Air Brooder, Price, reduced, only $\$ 6.50$ 

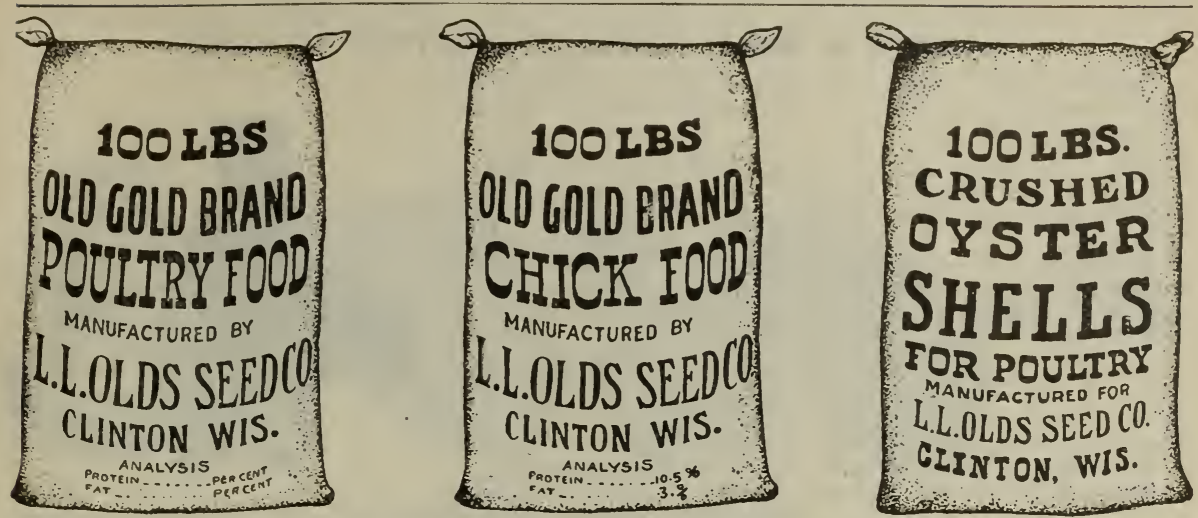

\section{OLD GOLE POULTRY FOOD.}

The demand for mixed poultry foods is constantly increasing. Farmers as well as professional poultrymen are learning that it pays best to buy their feed ready mixed in proper proportions, according to a fixed formula. Olds' Old Gold Poultry Food is manufactured right here at our warehouses, and has been prepared with a view to furnishing the largest variety of pure, clean grains and seeds suitable for laying hens. It contains about a dozen different ingredients, including cracked corn, wheat, kaffir corn, hulless barley, sunflower seed, buckwheat, etc. There is no trash in it. We make it up now without shells or grit. Those can be bought much cheaper separately. Duly analyzed and licensed, and every sack guaranteed. It contains a higher percentage of both protein and fat than most other poultry feeds. Costs less than any other similar feed.

Price: One sack (100 lbs.), $\$ 1.65 ; 3$ sacks at $\$ 1.60$.

\section{OLD GOLD CHICK FOOD.}

old Gold Chick Food is a dry food, suitable for chicks from 4 to 8 weeks old. (For the first 4 weeks, use Puritan Chick Food, described below.) Our Chick Food is made up even more carefully than the Poultry Food. Its analysis of protein and fat is about the same, and it contains much the same grains, only cracked finer, with quite a large proportion of millets of different kinds.

Price: One sack (100 lbs.), $\$ 1.80 ; 3$ sacks at $\$ 1.75$.

CRUSHED OYSTER SHELLS. Oyster shells are now a staple with almost erery progres. sire farmer in the country, as well as with every other man or woman who keeps poultry Our stock is the best that can be procured (genuine oyster and not clam shells), free from dust and dirt. Price, either poultry or chick size: One sack (100 lbs.), 70c; 3 sacks, \$2.00.

MICO-SPAR CUBICAL GRIT. Fast coming into favor among leading poultrymen as the most economical grit. Preferred by many to oyster shells. We have it in two sizes, poultry and chick. Price, same as for Oyster Shells.

(Write us for special prices on Grit and Shells in quantity. We buy in car lots. Orders for less than 100 pounds filled at 1 cent per pound.)

GROUND BONE. About the size of wheat. A small quantity mixed with other feed is very valuable at all seasons of the year. Price: $25 \mathrm{lbs}$., $75 \mathrm{c} ; 50 \mathrm{lbs}$., $\$ 1.35 ; 100 \mathrm{lbs}$., $\$ 2.50$.

BONE MEAI. Finer than ground bone. Should be mixed with wet feed. Price, same as Ground Bone. MEAT MEAL. Highly recommended for poultry. Thoroughly dried and will keep indefinitely. Price: 25 lbs., $75 \mathrm{c} ; 50 \mathrm{lbs}$., $\$ 1.35 ; 100 \mathrm{lbs}$., $\$ 2.50$.

BLOOD MEAL. Unexcelled for poultry and also as a concentrated stock feed. Price: 25 lbs., $\$ 1.00 ; 50$ lbs., $\$ 1.75 ; 100$ lbs., $\$ 3.25$

PURITAN CHICK FOOD. A perfectly balanced ration for young chicks for the first four weeks. This is the critical period and the time when many chicks are lost. Proper food would save them. Used by leading poultrymen. Price: 5 lbs., 25c; 25 lbs., $\$ 1.00 ; 50$ lbs., $\$ 1.75 ; 100$ lbs., $\$ 3.25$.

CHAMBERLAIN'S PERFECT CHICK FEED. A well-known and popular dry feed for chicks. Price, $\$ 2.50$ per sack (100 lbs.).

\section{PER GENT DISCOUNT}

On the following, to close out:

International Poultry Food. $25 \mathrm{c}, 50 \mathrm{c}$ and $\$ 1.00$ pkgs. $\$ 3.50$ pails.

International Stock Food. $25 \mathrm{c}, 50 \mathrm{c}$ and $\$ 1.00$ pkgs. $\$ 3.50$ pail.

International Gall Cure. $25 \mathrm{c}$ pkgs.
GRAINS, ETG.; FOR POULTRY.

\section{Feed Wheat, $80 \mathrm{c}$ per bu.}

Kaffir Corn, $\$ 1.25$ per $100 \mathrm{lbs}$.

Sunflower, $\$ 4.00$ per $100 \mathrm{lbs}$

Cracked Corn, $\$ 1.25$ per 100 ibs. Millet, $\$ 1.50$ per $100 \mathrm{lbs}$.

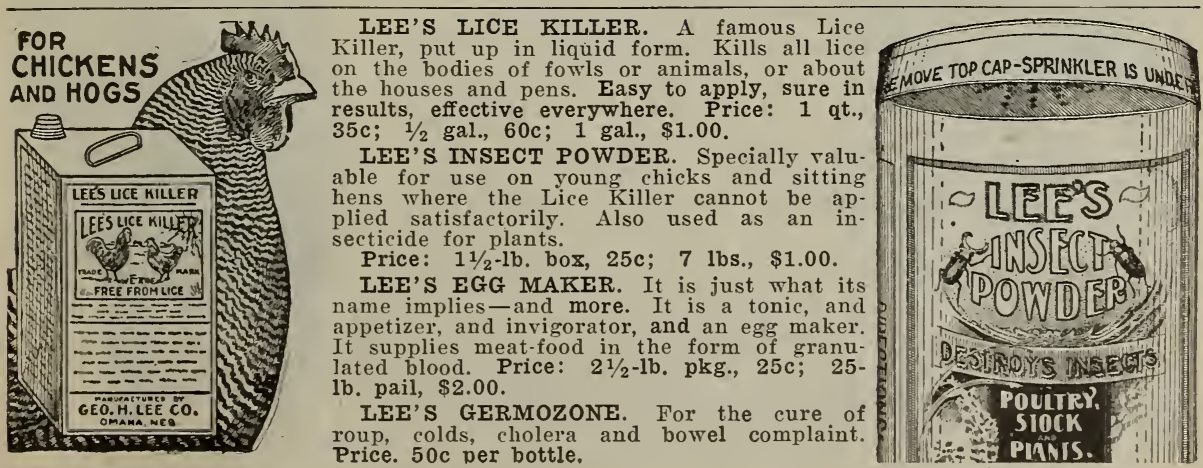




\section{CONKEY'S ROUP CURE, GUARANTEED TO CURE.}

Conquers Roup. Roup is the most fatal and dreaded disease of the poultry yard. It is very contagious, and quickly spreads through the flock.

The Cause. It is usually the result of a cold, contracted in various ways, such as crowded houses, exposure to cold and damp weather, drafty quarters, filthy surroundings, which weaken the constitution of the fowls and make them subject to disease.

Symptoms, Sneezing, followed by difficult breathing. Discharge from the nostrils and eyes, which quickly thickens, becoming cheesy looking; rattling in the throat; offensive odor, loss of vitality, etc.

Treatment. Conkey's Roup Cure is a positive cure for all forms of this disease. We guarantee this. If it should fail, your money will be refunded-no questions, just money. It is placed in the drinking water, the fowl takes its own medicine without knowing it, and you are relieved of any inconvenience.

Price, 50c per box, postpaid; makes 25 gallons medicine.

Price, $\$ 1.00$ per box, postpaid; makes 75 gallons medicine.

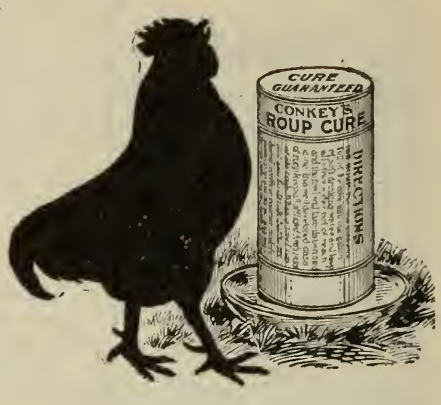

NEPONSET WATERPROOF PAPER FLOWER POTS.

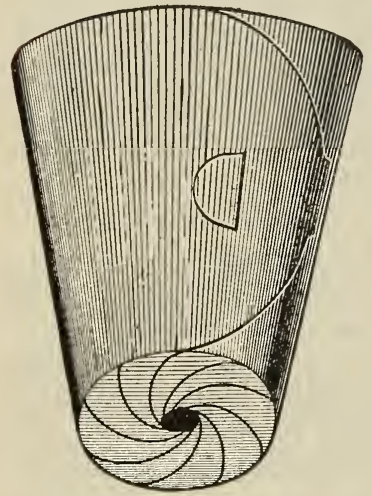

These are made of strong waterproof paper and are light and durable. They will not rot, and with proper care will last more than one season. Just the thing for starting young plants in, either vegetable or flower. Also very convenient for use in selling plants that are to be transplanted into the open ground. The clasp is easily released, when the pot may be removed, leaving the soil to be set into the ground with the plant undisturbed, after which the pot can be used over again. Any one who has a garden would find a hundred or so of these paper pots a great convenience, and for the florist and market gardener they are almost indispensable.

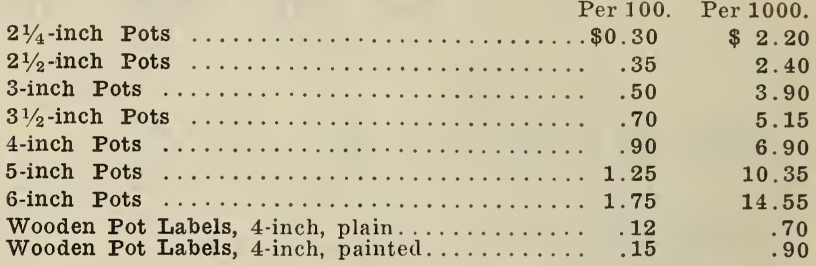

\section{SUCCESS SEED INCUBATOR AND PLANT PROPAGATOR.}

\section{"'SOMETHING NEW UNDER THE SUN.'}

The invention of a practical florist and seedsman of 30 years' experience.

An inexpensive device whereby anybody may successfully test all kinds of seeds, grow early vegetable and flower plants from seed, propagate flower plants from slips or cuttings, and care for blooming plants in the house during the winter months.

The device consists of iwo shallow pans made of galvanized iron and a detachable glass case. The lower pan is provided with divisions in the bottom which are connected with a small boiler beneath the center in such a manner that when filled with water and a lamp placed beneatl the boiler, we have a perfect circulating warm water system, insuring a uniform even temperature throughout the entire surface of the pan. The upper pan or propagating tray is 2 inches deep and rests on the divisions in the lower pan. It is perforated in the bottom for drainage, and is provided with detachable corner posts having grooves for holding glass in position, forming a closed glass case. By filling the propagating tray with soil or sand, inserting a thermometer (which we supply) and regulating the flame in the lamp, you can main. tain the temperature at any desired degree.

SOME OF THE USES OF THE SEED INCUBATOR.

1. For testing seed corn and other field seeds. Just what every farmer wants

2. For testing garden seeds of all kinds. Every careful market gardener wants to know exactly what per cent of each kind of seed will grow.

3. For starting early vegetable plants. Every farmer's wife will appreciate it for this purpose.

4. For growing flowers in winter. One man said, "Don't let my wife, see that, because if she does I will have to buy one for her !",

5. For a plant stand. This is one of its most valuable features, as it protects flowers and plants from freezing as well as being an ornamental piece of furniture.

Price, without stand, $\$ 4.75$; with stand, $\$ 5.75$.

(The above includes the entire outfit, water pan, boiler, tray, thermometer, trowel, label stakes, etc., except glass, which can be purchased at any hardware store for 40 or 50 cents.)

(Eight-page booklet with full detailed illustrations and descriptions free on request.)

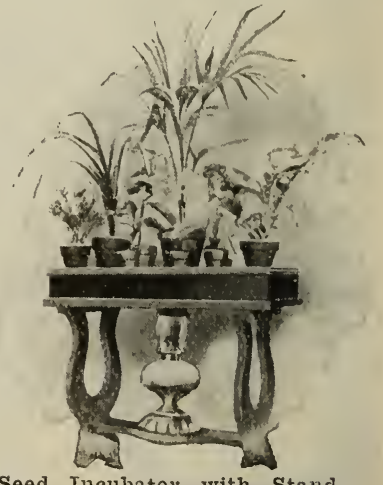

Seed Incubator with Stand. 


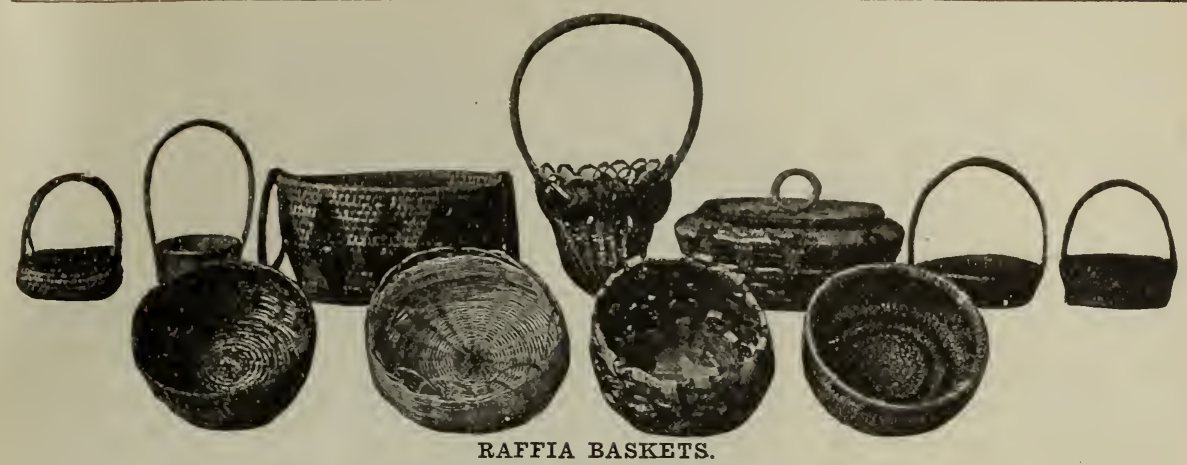

RAFFIA AND REEDS.

Basket wearing is most delightful and fascinating work. It is now recognized as such a useful art that it is taught the scholars in many of the public schools. Formerly this work was chiefly confined to Indians, and with the name "Indian Baskets", were connected mystery, cunning art and high prices. Since the introduction of Raffia, it has been found that the best Indian art can be closely imitated. Any one accustomed to needle work can, with a little practice, do very creditable work. Our Instruction Book gives full directions. Not only baskets lut many other fancy and useful articles can be made, such as picture frames, hats, whisk broom holders, plaques, napkin rings, etc. We are headquarters for Raffia, and besides the Natural, which is most used, we can furnish it in 14 colors. We also furnish Reeds in five sizes.

\section{PRIGES OF RAFFIA AND REEDS. Postage extra.}

\section{RAFFIA.}

Natural, 4-oz. bunch, 10c; 1b., 25c.

Red, 2-oz. bunch, 10c; lb., 65c.

Orange, $2 \cdot 0 \mathrm{z}$. bunch, $10 \mathrm{c} ; 1 \mathrm{~b} ., 65 \mathrm{c}$.

Yellow, 2-oz, bunch, 10c; lb., 65c.

Light Green, 2-oz. bunch, 10c; 1b., 65c.

Dark Green, 2-oz. bunch, 10c; 1b, 65c.

Light Blue, 2-oz. bunch, 10c; 1b., 65c.

Dark Blue, 2-oz. bunch, 10c; 1b., 65c.

Purple, 2-oz. buncli, $10 \mathrm{c}$; 1b., 65c.

Maroon, 2-oz, bunch, $10 \mathrm{c} ; 1 \mathrm{~b} ., 65 \mathrm{c}$.

Light Brown, 2-oz. bunch, 10c; ib., 65c.

Dark Brown, 2-oz. bunch, 10c; lb., 65c.

Black, 2-oz. bunch, 10c; 1b., 65c.

Prices do not include postage.
Size-

REEDS.

No. 1 (very small), oz., $10 \mathrm{c} ; 1 / 4$ lb., $30 \mathrm{c} ; 1 \mathrm{lb} ., \$ 1$. No. $2,1 \frac{112}{2} .0 \mathrm{z}$. bunch, $10 \mathrm{c}$; $1 / 4 \mathrm{lb}$., $20 \mathrm{c}$; 1b., $70 \mathrm{c}$. No. $3,1^{1 / 2} \cdot 0 \mathrm{z}$. bunch, $10 \mathrm{c} ; 1 / 4 \mathrm{lb}, 20 \mathrm{c} ; 1 \mathrm{~b} ., 70 \mathrm{c}$. No. 4, $1 \frac{1}{2} \cdot \mathrm{oz}$. bunch, $10 \mathrm{c}$; $1 / 4 \mathrm{lb}, 20 \mathrm{c}$; lb., $70 \mathrm{c}$.

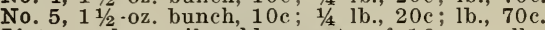
If to go by mail, add at rate of $16 \mathrm{c}$ per lb. or one cent per ounce.

Any 3 10-cent bunches Raffia or Reeds for 25 c.

Basket Making, by T. Vernette Morse, paper covers, 32 pages, illustrated, 25c, postpaid.

As a Collection Offer, we will furnish a 10-cent bunch each color of Raffia, with the Natural, and each size of Reeds, and also one copy "Basket Making." a complete outfit for a beginner, all for $\$ 1.50$. Not prepaid.

(Samples of Raffia and Reeds free on application.)

\section{TWO HARDY VINES.}

\section{Clematis, paniculata.}

The Clematis is a beautiful, hardy, rapidgrowing vine, and the Paniculata is the most satisfactory sort. The plant is a strong grower,

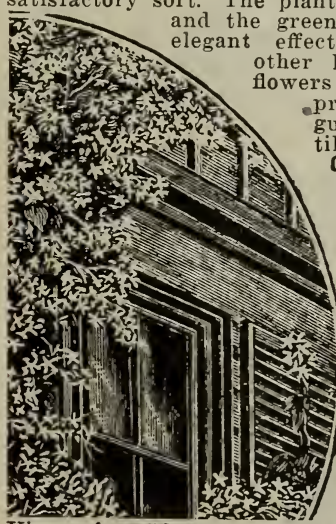

effect, possessed by no ther hardy climber. The appear in great profusion during $\mathrm{Au}$ gust and continue un til late in the fall. of easy culture and will grow any. where. It is like the orange blossom in bud, and the magnolia in fragrance. Hardy as an oak.

Strong Vines, 20 cts. each ; 3 for 50 cts., postpaid.

S P E C I A L OFFER. Two four a n d Vines for 50 cents. A great bargain-don't miss it.

SEEDS ALL RIGHT LAST YEAR.

"We ordered $\$ 60.00$ worth of seeds and plants of you last spring and everything was satisfactory. Enclosed find small order; will send a larger order next week

F. I. Steven, Harvard, Ill., April 16, 1906.

\section{GINNAMON VINES.}

The Cinnamon Vine is one of the most beau. tiful climbers - see illustration. It is easy to grow, and no home is complete without them. We are surprised that so little prominence has $\begin{array}{lrlll}\text { b e e } \mathrm{g} & \mathrm{g} \text { i } \mathrm{v} \text { e } \mathrm{n} \\ \text { heretofore } & \text { to }\end{array}$ heretofore to
this charming climber. The $\mathrm{C}$ i $\mathrm{n} n$ a $\mathrm{m}$ o $\mathrm{n}$ Vine, with slight protection over win. ter, will grow f o $\mathrm{r}$ several years, and can b e e a s i l y trained over and about a window (see illustration). $\mathrm{T} \mathrm{h} \mathrm{e}$ vines produce clusters of fragrant, delicate white flowers, and they will thrive a $\mathrm{n}$. where. Cinnamon Vines may also be grown

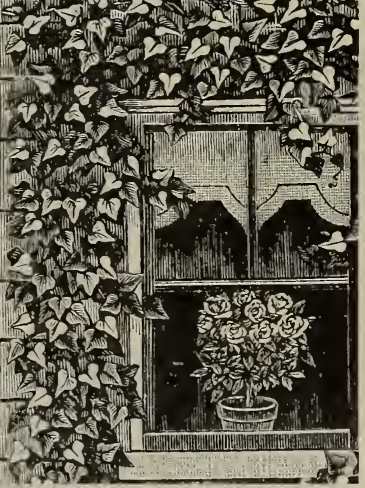
indoors and make a most charming window climber. We have secured a choice lot of roots, from the originator: Price, good strong roots, 5 cts. each; 6 for 25 cts.; doz., 40 cts., postpaid.

OUR GRAND OFFER. For 45 cents we will send, by mail, postpaid, six Cinnamon Vine roots and our Exposition Collection - see page 70 .

See pages 78 and 79 for our full list of Roses and other plants. Page 77 for Bulbs. 


\section{INDEX.}

\begin{tabular}{|c|c|c|}
\hline I'age & P'as & \\
\hline lfalfa & Flower Pots & Plants .... \\
\hline$\ldots \ldots \ldots \ldots \ldots+2$ & lower seed Novelties..........1s & $\begin{array}{l}\text { Potatoes, Novelties } \\
\text { l'otatoes, stamlaril }\end{array}$ \\
\hline s............. & 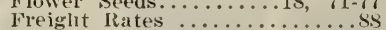 & 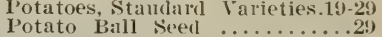 \\
\hline rley............, 5, 34, 35 & Garden Seed Novelties... & Potato Collections \\
\hline is, Garden... & arden Seeds, Standard Varie- & Potato Eye \\
\hline is...40 & ............. & 11 try \\
\hline Miangels $\ldots \ldots \ldots 12,45,49$ & $\begin{array}{l}\text { urds } \\
\text { ass seeds }\end{array}$ & ltry su \\
\hline …........... & intee ... & uns ofrers...... \\
\hline Gratis: & ..56, 85 & $\ldots 17$ \\
\hline .84 &.+1 & Ratlia \\
\hline is spouts & & \\
\hline & & arlo \\
\hline & illet & *k \\
\hline & .39 & agats \\
\hline 12,50 & Rabi & \\
\hline ed. . & .44 & \\
\hline is. & 14,57 & Incuba tors \\
\hline .13, & icat & \\
\hline ver & & ns \\
\hline . 51 & awin & \\
\hline & & \\
\hline 00 & s & \\
\hline 1 & & \\
\hline & $14,60,61$ & \\
\hline is, & Sets $\ldots \cdots \cdots$ & $\begin{array}{l}\text { Peas } . \\
\text { etc... }\end{array}$ \\
\hline 3,3 & Parsiey $\cdots$ & ( \\
\hline & Mixture & es $\ldots$ \\
\hline & & \\
\hline$. .13,5$ & Garden & ${ }_{T}^{T}$ \\
\hline 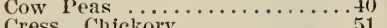 & & lfalfa \\
\hline $\begin{array}{l}\text { ickory } \ldots \\
\ldots \ldots \ldots\end{array}$ & sia $\ldots$ & Melons \\
\hline 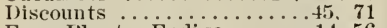 & .80 & $\cdots$ \\
\hline Endive........ & Planters.. & Vheat \\
\hline
\end{tabular}

FREIGHT RATES AT THIS DATE FROM CLINTON, WISCONSIN, TO STATIONS NAMED.

Per $100 \mathrm{lbs}$. on Third and Fourth Class Freight, in Barrels, Boxes or Sacks, Less than Car Lots.

Potatoes, Garden Seeds, Clover and Grass Seeds go as third class; Grain, Corn and Poultry Foods as fourth class. The shipping weight of a barrel of potatoes is $180 \mathrm{lbs}$. We do not have rates to other points east of Chicago. Secure approximate rate by noting rate to some point near you.

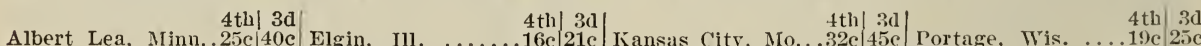

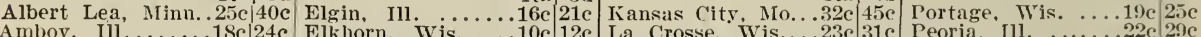

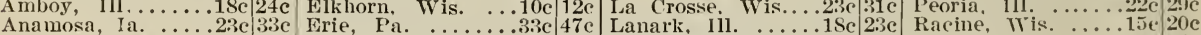

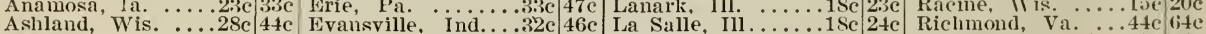
Ashland, Wis. $\ldots .28 \mathrm{c}$
Atchison, Kan

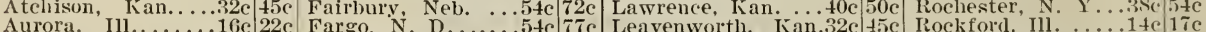

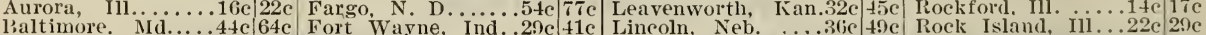

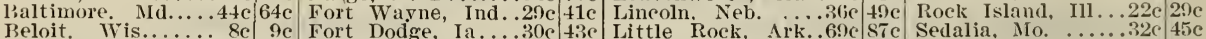

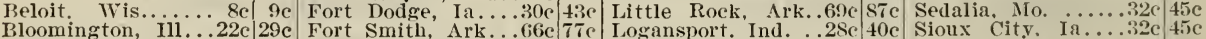

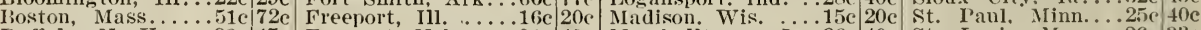
Buffalo, N. Y.....33e 47e Fremont, Neb.....36e tec Marshalitown. Ia..26ic 40e St. Louis, Mo....26e 3ise Burlington, Ia...22 2 29e Fullerton. Neb. ...64e $85 \mathrm{c}$ Mankato, Minn...27e 43e St. Joseph, Mo...32e 45e Carthage, Mo. ...45e 6.5 Gd. Rapids. Mich..30e +3e Nilwankee. Wis...15e 20e South Bend, Ind ..27c 38c

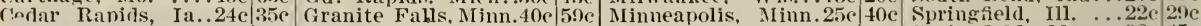

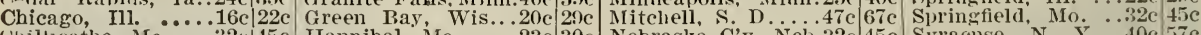

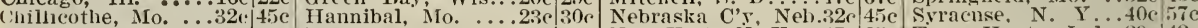

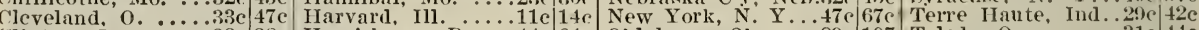

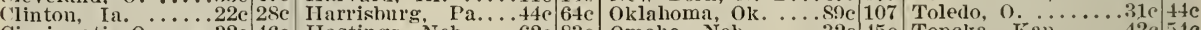

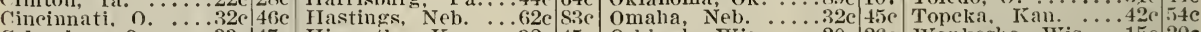

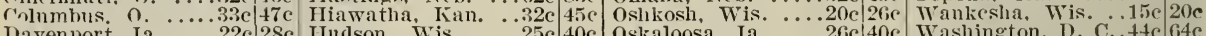

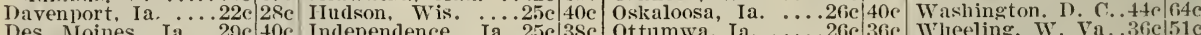
Des Detroit, Mich. ...31c 4te Indianapolis, Ind..29e 42c. Pawnee (ity, Nel.39e 52c Wichita, Kinn. .... fitc .1e

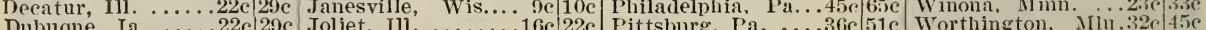
Dubugne, Ia $\ldots .22 \mathrm{c}$
Eau Claire. Wis...25e

HOLT'S MAMMOTH SAGE. The leaves are borne well above the ground; they are very large (see illus. tration); of good substance

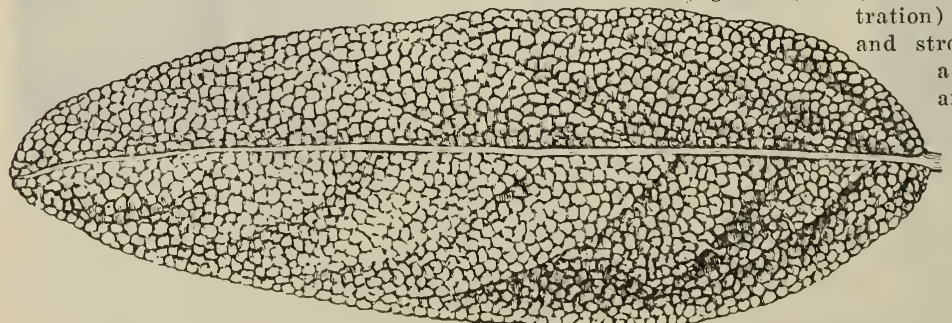
a very hardy plant and is the most desirable sage, but it never sceds.

Strong plants, 10 cents each; 3 for 25 cents; 7 for 50 eents; 15 for $\$ 1.00$, by mail, postpaid. 
OLDS’ MODEL COLLECTION.

The varieties shown on our back corer. One Packet each of tile four, $25 \mathrm{c}$.

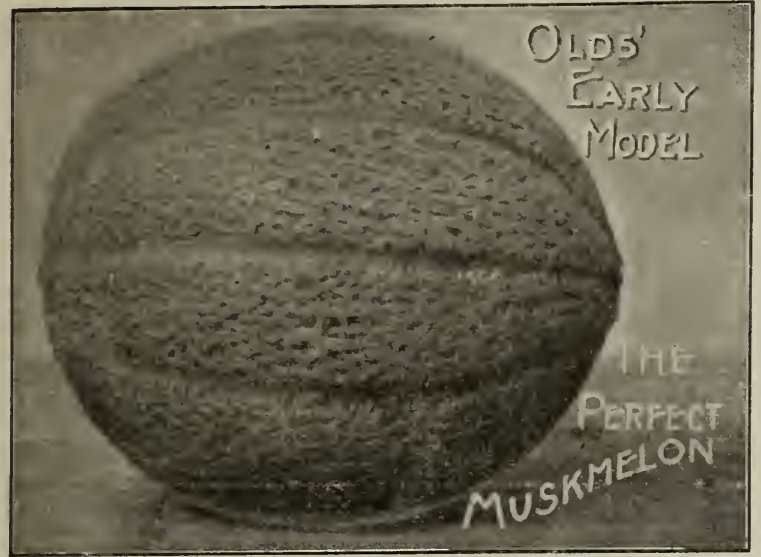

STANDARD FOR SEED
SELEGTION
For Olds' Early Model.
Prolific Yield.
Early Maturity.
Drought Resistance.
Thick, Spicy, Green Flesh.
Flavor Equaling Rocky Ford.
Small Seed Cavity.
Smooth and Firm Texture.
Correct Size and Shape.
The illustration is from a
photograph of a perfect speci-
men grown by Mr. Wilson.
Weight, 2 pounds.

OLDS' EARLY MODEL. The Perfect Muskmelon. The Early Model withstands drought remarkably well; it averages about two pounds in weight-is perfect in shape (see illustration); is very productive and possesses all the good qualities of the Rocky Ford. Full description, page 15. Pkt., 10 cts.; oz., 20 cts.; 1/4 lb., 50 cts.; lb., $\$ 1.25$, postpaid.

OLDS' ROUND POD WAX. The Handsomest Wax Bean. This new bean combines all the good qualities of Wardwell's Kidney Wax, together with those of the best round-podded sorts. It is the same in season as Wardwell's, very prolific and entirely free from rust; plants strong and stocky; pods large, handsome and stringless - the best second early. Pkt., 10 cts.; pt., 25 cts.; qt., 40 cts., postpaid. Not prepaid: Qt., 25 cts; pk., $\$ 1.75 ;$ bu., $\$ 6.00$.

OLDS' DWARF. TELEPHONE. The Most Prolific Dwarf Pea. It produces large, handsome pods, with a short vine; it is medium early and very productive. Full description, page 15. Pkt., 10 cts.; 2 plts., 15 cts.; pt., 25 cts.; qt., 45 cts., postpaid. Not prepaid: Qt., 30 cts.; pk., $\$ 2.00 ;$ bu., $\$ 7.50$.

OLDS' EARLY NEAPOLITAN. The Largest and Earliest Pepper. Bright red, thick-meated, sweet and mild; also very productive. Full description, page 14. Pkt., 5 cts.; oz., 20 cts.; 1/4 lb., 75 cts., postpaid.

At catalogue prices, one packet each of the 4 varieties above mentioned would amount to $35 \mathrm{cts}$; but to induce an order for them, we offer the collection for 25 cts., postpaid. Not prepaid, 5 collections for $\$ 1.00$.

Order anything from this catalogue to the amount of $\$ 1.00$ or more, and we will add FREE, on request, one packet of the EARLY MODEL MELON-be sure and ask for it when you order.

BABY RAMBLER ROSE. This new rose is decidedly a distinct variety. It is identical in every way with the favorite Crimson Rambler, except that it is dwarf and bushy. It is a constant bloomer, grows 18 inches high, and the plant is almost hidden with rosessee illustration. Strong plants, $25 \mathrm{cts}$. each; 3 for 60 cts.; 2-year-old plants, 50 cts. each, postpaid.

BABY PRIMROSE. The freest blooming plant we know of, blooming continuously throughout the entire season. 5 cts. each. Two Baby Ramblers and 2 Baby Primroses for $50 \mathrm{cts}$., postpaid.

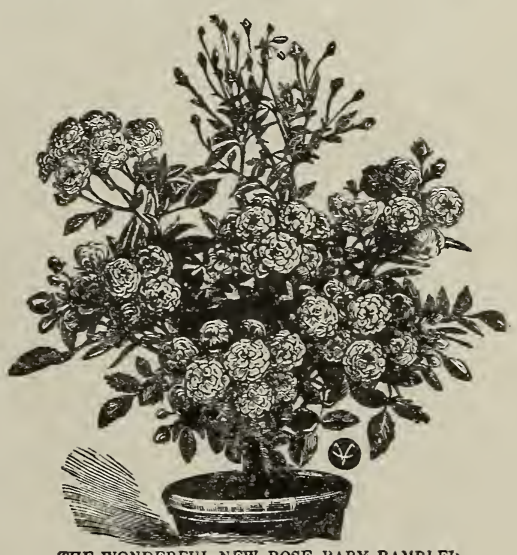

THE WONDERFUL NEW ROSE, BABY RAMBLEK,

\section{WHAT WE DO.}

A LAST WORD TO OUR GARDEN AND FLOWER SEED CUSTOMERS.

SAMPLE PACKETS FREE. We have a few new things that are worth testing and which we will give free, if asked for at time of ordering - see pages 13,15 and 59.

CASH DISCOUNTS. We believe we are the only seedsmen allowing a straight Cash Discount. We allow 25 per cent discount on Vegetable seeds, ordered by the packet and ounce isce page 45) - 30 per cent discount on Flower Seeds, by the packet (see page 71), and from 5 to 15 per cent discount on Garden Seeds in larger quantities than ounces (see page 45).

OUR SEEDS GROW. Nearly all seedsmen test their seeds for germination before sending them out. We keep a record of our tests and stamp each package, whereby we can tell exactly what the germination is, of any particular stock - see page 45.

SIZE OF PACKETS. We give under each heading the quantity of seed each package con. tains, also how much space it will plant. By comparison, it will be found our packets contain as much seed as those of the highest priced seedsmen-see page 52 .

SEED REQUIRED TO PIANT AN ACRE. We give also under each heading the correct quantity of seed required to plant an acre-see page 56.

CULTURAI DIRECTIONS. We give cultural directions with every packet and ounce.

SUBSTITUTION. We will not substitute unless given permission to do so-see page 54 .

GUARANTEE. We guarantee everything we send out to be as represented.

POSTPAID. We deliver seeds to any post-office at catalogue prices, when quoted pcstpaidsee pages 17,45 and 71 .

REMITTANCES. Deduct the cost of the P. O. or Ex. Order from the amount of the remittance-see express money order blank enclosed.

TESTIMONIALS. Our testimonials are misolicited. We will send more of them on requestwe give full addresses and would be pleased to have any of them used as references- see page 17.

WELL-PI.EASED CUSTOMERS HATE MADE OUR SUCCESS-IET US HEAR FROM YOU. 
